UNIVERSIDADE DE SÃO PAULO

FACULDADE DE EDUCAÇÃO

Mateus Moisés Gonçalves Pereira

Tessituras da queda: deseducação em Raduan Nassar 

Mateus Moisés Gonçalves Pereira

\title{
Tessituras da queda: deseducação em Raduan Nassar
}

\author{
Versão Corrigida
}

Dissertação apresentada à Faculdade de Educação da Universidade de São Paulo, como requisito parcial para obtenção do título de Mestre em Educação.

Área de concentração: Cultura, Filosofia e História da Educação

Orientador: Prof. Dr. Rogério de Almeida

São Paulo

2019 

AUTORIZO A REPRODUÇÃO E DIVULGAÇÃO TOTAL E PARCIAL DESTE TRABALHO, POR QUALQUER MEIO CONVENCIONAL OU ELETRÔNICO, PARA FINS DE ESTUDO E PESQUISA, DESDE QUE CITADA A FONTE.

Catalogação da Publicação

Ficha elaborada pelo Sistema de Geração Automática a partir de dados fornecidos pelo(a) autor(a) Bibliotecária da FE/USP: Nicolly Soares Leite - CRB-8/8204

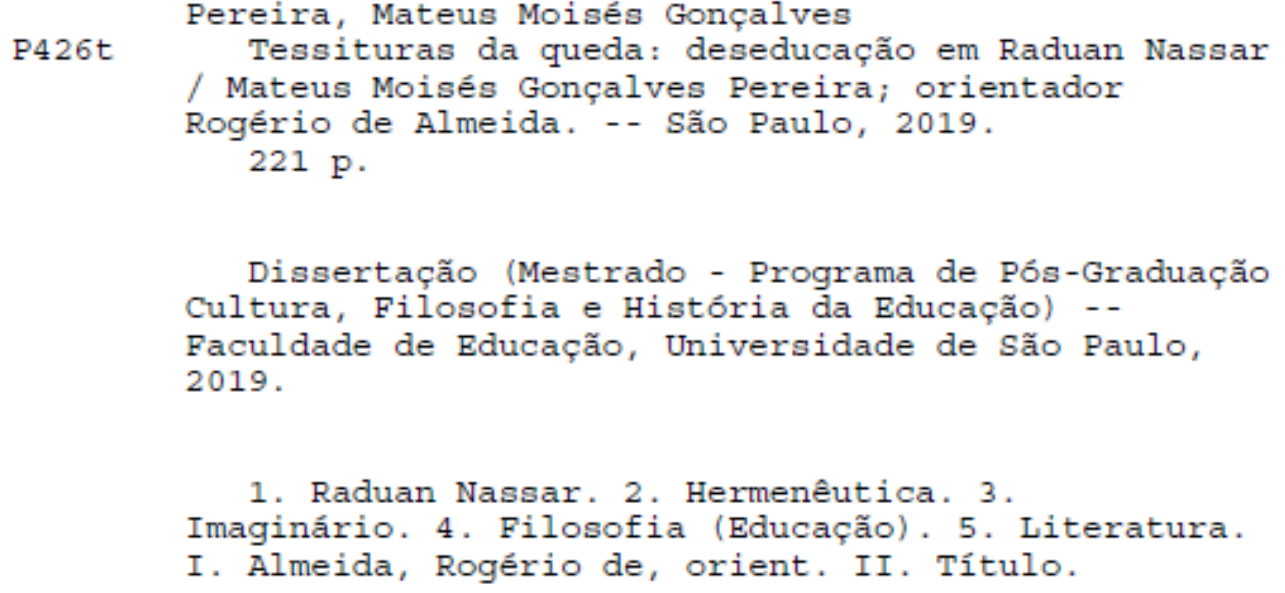

1. Raduan Nassar. 2. Hermenêtica. 3. Imaginário. 4. Filosofia (Educação). 5. Literatura. I. Almeida, Rogério de, orient. II. Título. 

Nome: PEREIRA, Mateus Moisés Gonçalves

Título: Tessituras da queda: deseducação em Raduan Nassar

Dissertação apresentada à Faculdade de Educação da Universidade de São Paulo, como requisito parcial para obtenção do título de Mestre em Educação.

Data:

\section{Banca Examinadora}

Prof. Dr.

Instituição:

Julgamento:

Prof. Dr.

Instituição:

Julgamento:

Prof. Dr.

Instituição:

Julgamento: 



\section{AGRADECIMENTOS}

Manifesto minha gratidão à Coordenação de Aperfeiçoamento de Pessoal de Nível Superior (CAPES) pela bolsa concedida e ao Programa de Pós-Graduação em Educação da FEUSP pela oportunidade oferecida. Sou grato pela orientação e mestria de Rogério de Almeida, tão fértil, generosa e amistosa. Agradeço as importantes contribuições de meus professores durante a trajetória na Faculdade de Educação, em especial ao Marcos Sidnei Pagotto-Euzebio pela rigorosa e afetuosa mestria. Sem a paixão, o suporte, a paciência, o amor e as partilhas com minha esposa Clarice Vaz de Oliveira a vida não teria a beleza e a potência que busquei transpor para esta dissertação. Sou muito grato pelo incentivo e pelo apoio que tive desde sempre de toda a minha família, em especial à minha mãe Dilair Cremasco Gonçalves Pereira e ao meu pai Raimundo Gonçalves Pereira. Destaco o papel formativo dos meus amigos e colegas da USP em meus caminhos. $\mathrm{O}$ resultado desta pesquisa teve a valiosa contribuição das avaliações e comentários de André Luis Rodrigues e Maria José Cardoso Lemos durante o exame de qualificação. Sob a leveza de um destino forte, que a paixão partilhada por Raduan Nassar sempre nos traga colheitas fecundas, certo de que se há muito farelo nisso tudo há também aí muito grão inteiro.

- Ao longo dos anos alguns episódios acabaram me levando a pôr atenção menos na ideologia e mais na qualidade dos seus portadores - Raduan Nassar. 



\section{RESUMO}

PEREIRA, M. M. G. Tessituras da queda: deseducação em Raduan Nassar. [Shades of falling: Raduan Nassar's dis-education]. 2019. 221 f. Dissertação (Mestrado em Educação) Faculdade de Educação, Universidade de São Paulo, São Paulo, 2019.

Este trabalho apresenta o imaginário da queda na obra completa de Raduan Nassar. Compreende-se a literatura nassariana como locus privilegiado de expressão da sexualidade e de crises morais. Entende-se a educação em um sentido amplo, nomeadamente, no esteio dos itinerários de (auto)formação: o exercício formativo como experiência de encontro e escolha. Recupera-se a literatura em seu aspecto formativo pensando o texto literário como metáfora da condição do homem no mundo. Ancora-se em uma razão complexa e em uma razão sensível, sob a regência do gradiente holonômico. Sustenta-se metodologicamente por uma antropologia do imaginário e por uma hermenêutica simbólica. O tratamento hermenêutico se realiza através das repetições e recorrências simbólicas na obra nassariana. Os resultados apontam uma (est)ética formativa ancorada no aspecto performático do texto e na afirmação cotidiana do homem comum, experiências das quais sobressaem resquícios de liberdade radicados na potência da vida. Conclui-se que o universo nassariano confere ao leitor um processo de deseducação, já que desconstrói um conjunto de valores atrelados à razão e ao progresso moral, fundamentos da educação moderna.

Palavras-chave: Raduan Nassar. Educação. Hermenêutica simbólica. Imaginário da queda. 



\begin{abstract}
PEREIRA, M. M. G. Shades of falling: Raduan Nassar's dis-education. [Tessituras da queda: deseducação em Raduan Nassar]. 2019. 221 f. Dissertação (Mestrado em Educação) Faculdade de Educação, Universidade de São Paulo, São Paulo, 2019.

This work aims to present the fall's imaginary in the complete work of Raduan Nassar. The nassarian literature is recognized as a privileged locus of sexuality and of moral crises. Education is conceived in an extended perspective, specifically regarding (self) formation itineraries: the formative activity as experience of encounter and choice. The literature is recovered in its formative aspect, conceiving the literary text like a metaphor about man in the world. This is bounded at a complex reason and at a sensitive reason, under the influence of the holonomic gradient. The methodology is sustained by the imaginary's anthropology and by the symbolic hermeneutics, which is materialized through the hermeneutic treatment of the nassarian works. The results point to a formative (aesth)ethics anchored in the performative aspect of the text and in the daily affirmation of the common man, experiences of which stand out remnants of freedom rooted in the power of life. It is concluded that the nassarian universe confers to the reader a process of dis-education, since it deconstructs a set of values linked to reason and moral progress, foundations of contemporary education.
\end{abstract}

Keywords: Raduan Nassar. Education. Symbolic hermeneutic. Fall's imaginary. 



\section{LISTA DE FIGURAS}

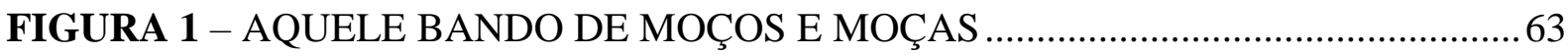

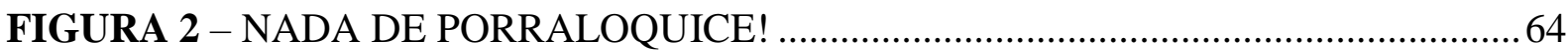

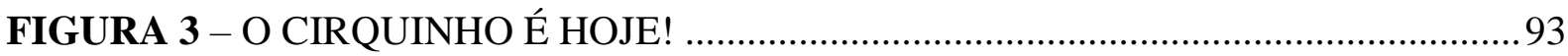

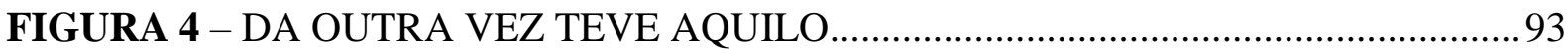

FIGURA 5 - UM GINASIANO PEDALANDO TRANQUILAMENTE .............................94

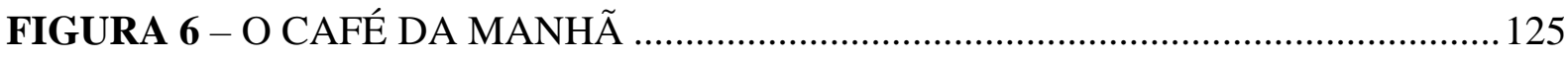

FIGURA 7 - A GRAVIDADE NEGRA E ERECTA DOS CIPRESTES .......................... 125

FIGURA 8 - A DEPOSITÁRIA ESPIRITUAL DE UM PATRIMÔNIO ESCASSO ......... 126

FIGURA 9 - PERDIDAS ENTRE OS AFAZERES NA COZINHA .................................. 161

FIGURA 10 - ERA UMA CIÊNCIA DE MENINO ....................................................... 162

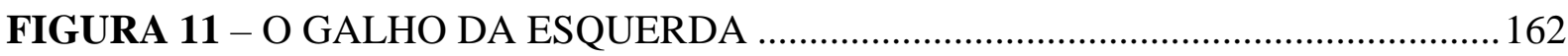

FIGURA 12 - NÃO TINHA OLHOS ESSE NOSSO AVÔ................................................ 163

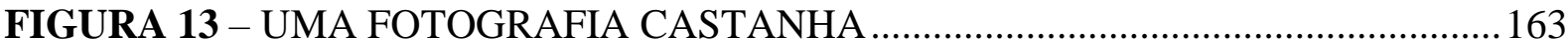





\section{LISTA DE SIGLAS}

$\begin{array}{ll}\text { CC } & \text { UM COPO DE CÓLERA } \\ \text { CEH } & \text { A CORRENTE DO ESFORÇO HUMANO } \\ \text { HM } & \text { HOJE DE MADRUGADA } \\ \text { LA } & \text { LAVOURA ARCAICA } \\ \text { M } & \text { MONSENHORES } \\ \text { MC } & \text { MENINA A CAMINHO } \\ \text { MS } & \text { MÃOZINHAS DE SEDA } \\ \text { TB } & \text { AS TRÊS BATALHAS } \\ \text { TT } & \text { AÍ PELAS TRÊS DA TARDE } \\ \text { V } & \text { O VELHO } \\ \text { VS } & \text { O VENTRE SECO }\end{array}$





\section{SUMÁRIO}

INTRODUÇÃO ....................................................................................................19

1 ITINERÁRIOS DE INVESTIGAÇÃO POÉTICA ......................................................25

1.1 UMA COMPREENSÃO FORMATIVA DA LEITURA E DA LITERATURA .......... 25

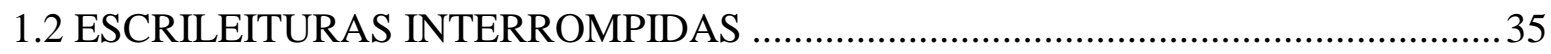

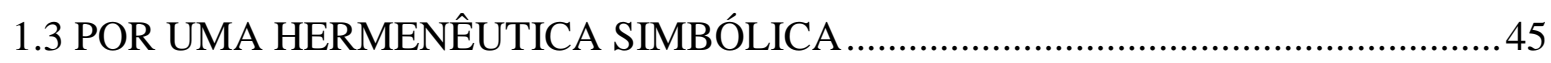

1.3.1 Teoria e método no horizonte de uma mudança paradigmática ...........................46

1.3.2 Fundamentos para uma antropologia do imaginário ............................................52

1.3.3 Uma hermenêutica simbólica ...................................................................................55

1.3.4 Aportes metodológicos .....................................................................................................60

2 ERRARE HUMANUM EST.................................................................................................63

2.1 EM SOLO TURVO: TERRITÓRIOS NASSARIANOS ……………………………....... 65

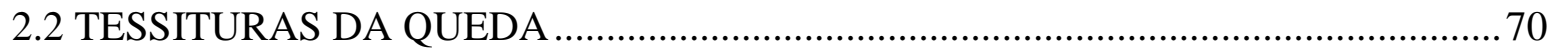

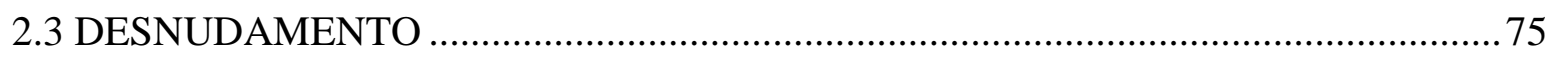

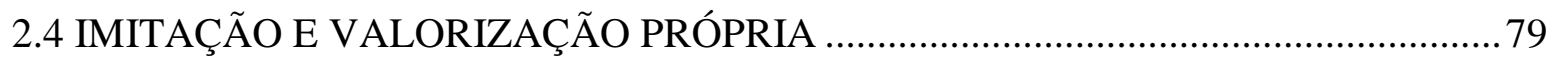

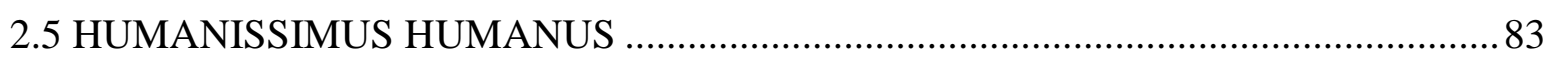

2.5.1 Binário ............................................................................................................................ 83

2.5.2 Espiral ....................................................................................................................... 85

2.5.3 Queda (I) ....................................................................................................................... 87

2.5.4 Vontade ................................................................................................................................89

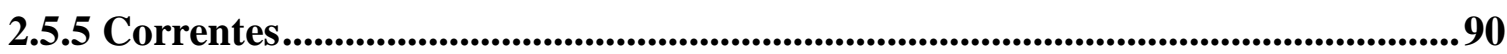

3 (RE)ENCONTRANDO PINDORAMA ..........................................................................93

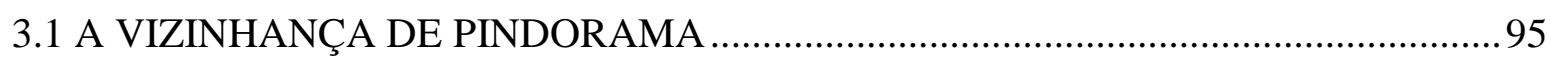

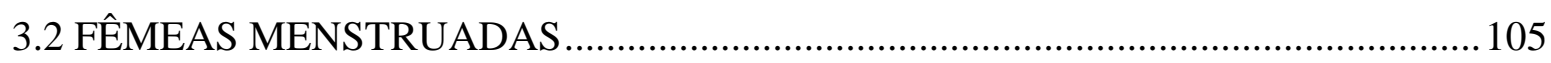

3.3 INTERIOR

3.3.1 Idílico ...............................................................................................................................108

3.3.2 O espetáculo dos segredos .............................................................................................114

3.3.3 Queda (II): estradas e caminhos .................................................................................119

4 A PROMISCUIDADE DO PODER............................................................................125

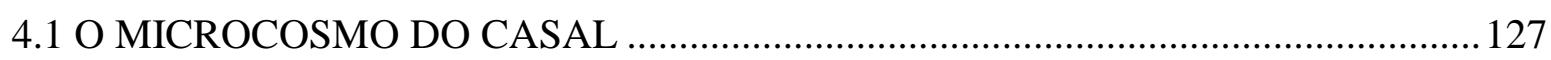

4.2 A FEMEAZINHA EMANCIPADA E O FASCISTÃO ................................................135

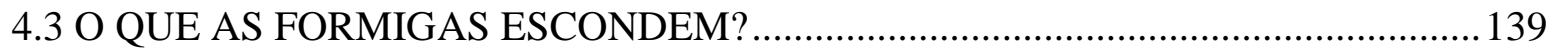


4.3.1 Títeres …......................................................................................................................... 139

4.3.2 Professor .............................................................................................................................. 145

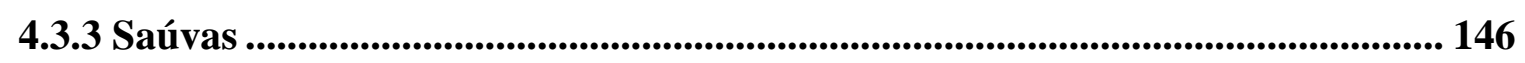

4.3.4 A recusa e o espelho ..................................................................................................... 150

4.3.5 Queda (III): escuridão progressiva ......................................................................... 157

5 O ELOGIO DA DIMENSÃO SENSÍVEL E ESTÉTICA DA VIDA.............................. 161

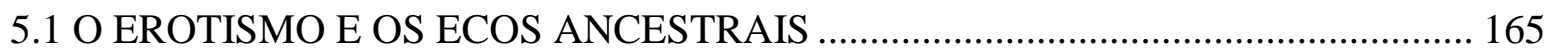

5.2 O QUE NÃO TEM GOVERNO, NEM NUNCA TERÁ.............................................. 197

5.2.1 Raízes ..................................................................................................................... 197

5.2.2 Fluídos........................................................................................................................... 201

5.2.3 O edifício e a caldeira ..................................................................................................... 204

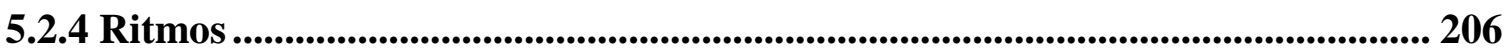

5.2.5 Memórias ..................................................................................................................... 208

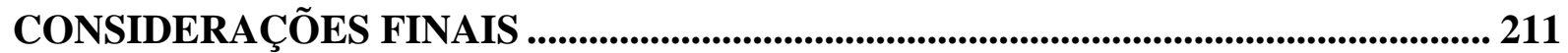

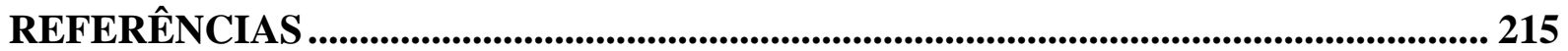




\section{INTRODUÇÃO}

Raduan Nassar foi o sétimo filho do casal de imigrantes libaneses estabelecidos em 1921 na cidade de Itajobi no interior de São Paulo. João Nassar e Chafika Cassis tiveram dez filhos. De seus seis irmãos mais velhos cinco deles cursaram Filosofia na antiga Faculdade de Filosofia e Letras da rua Maria Antônia, como ele também o fez. Na mesma instituição sua irmã Rosa cursou Letras Clássicas tendo sido sua professora durante a antiga oitava série. A irmã mais velha recomendava a leitura de clássicos da literatura brasileira e aperfeiçoava o aprendizado da língua de seu irmão.

Nassar responde por uma pequena obra composta pelos premiados Lavoura arcaica (1975) e Um copo de cólera (1978) além da coletânea de contos Menina a caminho e outros textos (1997). O conto "O velho" e o ensaio "A corrente do esforço humano", até então inéditos no Brasil, foram publicados em sua Obra completa (2016), acompanhados do também inédito "Monsenhores". Vencedor do Prêmio Camões em 2016, Raduan é enigmático e reservado. Abandonou a literatura em 1984 e, desde então, aparece pouco em público e concede raras entrevistas. Passou por três cursos superiores (Direito, Letras e Filosofia), foi criador de coelhos, jornalista, escritor, mas se consolidou, afinal, como produtor rural. A Fazenda Lagoa do Sino, onde hoje se localiza um campus da Universidade Federal de São Carlos, foi por trinta anos seu grande empreendimento até que em 2011 doou a propriedade ao governo federal.

O escritor produziu Lavoura arcaica em 1974 trabalhando dez horas por dia durante oito meses a partir de anotações feitas entre 1969 e 1970. O romance é uma paródia da parábola bíblica do filho pródigo. Sob o estigma da ambiguidade familiar, entre a austeridade do pai e o afeto da mãe, André, Ana e Lula são a face corrompida dos valores milenares transmitidos do avô ao pai. A paixão incestuosa de André pela irmã Ana leva o irmão torto a deixar a casa da família, situada em uma fazenda. Vivendo na prodigalidade, em uma pensão de vila nas proximidades, André é surpreendido pela visita do irmão mais velho, Pedro, com a missão de trazê-lo de volta ao seio familiar. A narrativa, marcada pela implacabilidade do destino, é composta pelo fluxo de consciência de André, evocando memórias da infância e da adolescência na primeira parte (“A partida”) e recobrando aspectos dramáticos e trágicos da condição humana na segunda parte (“O retorno”) com (as)simetrias e contaminações recíprocas.

\footnotetext{
${ }^{1} \mathrm{O}$ ensaio fora publicado na Alemanha com o nome Nachahmung und Eigenwert na obra Lateinamerikaner über Europa (NASSAR, 1987). Neumann (2007) o traduziu como "Imitação e valorização própria".
} 
O romance foi adaptado para o cinema em Lavoura arcaica (BRA-2001), dirigido por Luiz Fernando Carvalho, que venceu mais de quarenta prêmios nacionais e internacionais. $\mathrm{O}$ documentário Que teus olhos sejam atendidos ${ }^{2}$, também de Luiz Fernando Carvalho, relata a viagem que o diretor e Raduan Nassar fizeram ao Líbano durante o período de preparação e pesquisa para o filme.

Um copo de cólera foi escrito em 1970 durante 15 dias seguidos e, anos mais tarde, em 1976, retomado e retrabalhado por 6 meses para publicação efetiva que ocorreu em 1978 pela Editora da Livraria Cultura. A novela Um copo de cólera é o testemunho de momentos de intimidade de um casal em uma chácara. Os personagens sem nome chegam ao local em uma permanente tensão que se intensifica e dissolve nas sensuais cenas de sexo. O casal é ao mesmo tempo cumplice e inimigo e os gestos de ambiguidade se constroem desde os primeiros capítulos, preâmbulos para o capítulo decisivo, "O esporro". O chacareiro, raivoso com o furo na cerca viva de sua propriedade, começa uma cena teatralizada cheia de veneno. Daí em diante a mulher e o homem trarão à tona as contradições e os pontos cegos um do outro em uma ira crescente. O filme Um copo de cólera (BRA-1999) foi lançado como longa metragem com direção de Aluizio Abranches.

Alguns contos de Raduan foram publicados no livro Menina a caminho e outros textos (NASSAR, 1997). Escrito em 1960 o conto "Menina a caminho", antes de aparecer neste livro, foi publicado na Coletânea alemã de contos brasileiros em 1982 pela primeira vez e na Coletânea mexicana de contos brasileiros em 1997. "MC" já havia saído em uma edição não comercial da Companhia das Letras em 1994. O texto trata das andanças de uma garota em uma cidade do interior. Escrito em terceira pessoa, acompanha o trajeto da menina num dia de tensão: algo imoral ocorreu entre sua mãe e o filho do seu Américo. Todas as pessoas da cidade estão comentando e se revoltando contra o tal rapaz.

"Aí pelas três da tarde" foi o primeiro texto literário publicado por Raduan". Veio a público como matéria jornalística no Jornal do Bairro em 1972. Foi publicado novamente no livro A posse da terra, de Cremilda de Araújo Medina (1985), no periódico espanhol El Paseante (1985), no caderno Ilustrada da Folha de São Paulo (1985) e neste mesmo jornal em 1989. Finalmente, sairá na reunião de contos Menina a caminho e outros textos (NASSAR,

\footnotetext{
${ }^{2}$ O documentário estreou no GNT em dezembro de 1997. "Que teus olhos sejam atendidos" consta no segundo disco de uma edição especial de Lavoura arcaica (BRA-2007).

${ }^{3}$ Sem considerar os remotos "As bestas do apocalipse" e "A bengala de cada um" dentre outros publicados no Jornal do Bairro entre 1967 e 1974 (ABATI, 1999). Além disso, no contexto do jornalismo político, é válido citar o texto "Rural x Urbano" (NASSAR, 1999) e os recentes "Estamos bem arrumados!" (idem, 2016b) e "Cegueira e Linchamento" (idem, 2016c). Nestes dois últimos Raduan critica a política brasileira vigente desde o golpe de 2016.
} 
1997). O conto descreve o transe de um jornalista abandonando a redação no meio da tarde sem qualquer pretexto ou explicação e surpreendendo a família em casa com um comportamento desajustado.

Escrito em 1970, “O ventre seco” veio a público pela primeira vez em 1984 no Folhetim, também no El Paseante em 1985 e no suplemento Ideias do Jornal do Brasil em 1989, antes de figurar na reunião de contos de 1997. "VS" é como um apêndice ou preâmbulo de Um copo de cólera. Simulando um telegrama com 15 tópicos o conto esclarece os motivos e informa o rompimento de um relacionamento amoroso do narrador, um homem mais velho, com Paula, moça mais nova. "Hoje de madrugada", por sua vez, foi escrito em 1970 e publicado pela primeira vez nos Cadernos de Literatura Brasileira em 1996. O conto descreve os apelos não correspondidos de uma mulher que busca afeto e amor de seu marido.

O bem-humorado "Mãozinhas de seda", escrito especialmente para o Cadernos de Literatura Brasileira em 1996, acaba sendo publicado somente na reunião de contos do ano seguinte. $\mathrm{O}$ conto relaciona o aperto de mão dos intelectuais com as delicadas mãos de donzelas da cidade de Pindorama na época do Baile da Primavera durante a infância do autor, ambos supostamente agraciados pelos afagos da pedra-pomes. "MS" é uma crítica irônica ao comércio de prestígio nos meios intelectualizados.

Já os contos “O velho" e "Monsenhores", escritos em meados de 1958, são os primeiros escritos literários de Nassar. "V" fora publicado na França em Des nouvelles du Brésil (1998). Com atmosfera próxima de "MC" este o conto, publicado no Brasil em 2016, mostra a perplexidade de um idoso diante dos comentários que se espalham sobre um de seus hóspedes. Não havia sequer menção da existência de "M" até a Obra completa. O conto narra com angústia e suspense uma inusitada estória de incesto. Escrito ao final da década de 1980 o ensaio "A corrente do esforço humano" discute as relações políticas, socioeconômicas e culturais entre os países desenvolvidos, sobretudo aqueles do continente europeu, e os países em desenvolvimento, com especial atenção para o Brasil e os vizinhos latino-americanos.

Os sete contos e dois livros se dispõem cronologicamente nesta ordem: "V" e "M" (1958); "MC" (1960/1961); LA (1968-1969/1974); "HM" e "VS" (1970); CC (1970/1976); “TT" (1972); "CEH” (1987); "MS” (1996). Ordenados pela data de publicação: “TT" (1972), LA (1975), CC (1978), “MC” (1982), “VS” (1984), “HM” (1996), “MS” (1997), “V” (2016), "M" (2016)

\footnotetext{
${ }^{4}$ Cite-se também o texto "Desespero e esperança" publicado na antologia Ritos de passagem de nossa infância e adolescência (ABRAMOVICH, 1985), uma compilação de um trecho da entrevista a Edla Van Steen (1983) em que o escritor conta como conseguiu na infância pronunciar o $r$ fraco cantando o hino da bandeira.
} 
A literatura nassariana destaca-se em forma e conteúdo consagrando o escritor entre os principais nomes brasileiros. Seu exercício singular de pontuação, o vocabulário apurado, o uso peculiar dos mecanismos da língua e a mistura de gêneros são motivos de críticas positivas desde sua estreia na literatura. Os temas de Raduan são densos e polêmicos, marcados pela vontade, pelo poder, pela sexualidade, pelo desejo, pela violência, pelo êxtase, pelo conflito, desenvolvidos no incesto, na surra, na angústia, na culpa e no mal. A fusão entre lirismo e sobriedade, entre poesia e prosa, elevam seus livros à condição de obras-primas. Os contos nassarianos, a Safrinha, não fazem por menos: expandem a temática do escritor e acrescentam elementos para o notório talento empregado ao dissecar a condição humana.

A jornada interpretativa a qual nos dedicamos durante o período deste curso de Mestrado em Educação, somada à nossa trajetória anterior e paralela à escrita desta dissertação, nos reservou a convicção de que a literatura nassariana pode ser interpretada a partir da reunião de um conjunto de símbolos, imagens e mitos que constelam e orbitam em torno do arquétipo da queda. Desse modo, identificamos os conflitos de valores e a sexualidade como elementos centrais no universo nassariano, ao que firmamos o objetivo de apresentar simbolicamente a obra completa de Raduan Nassar em torno de um imaginário da queda. Para a hermenêutica simbólica instada na confecção desta dissertação, além das perspectivas instauradoras de Gilbert Durand e Paul Ricoeur ${ }^{5}$ e de instrumentos oriundos de outros campos das humanidades e artes, concorrem o ponto de vista pessoal deste que escreve, sem deixar de incorporar referências à trajetória de Raduan, incluindo depoimentos e entrevistas.

Dentre os recursos filosóficos utilizados constam Arthur Schopenhauer, recuperado a partir de comentadores, Friedrich Nietzsche e Georges Bataille. No âmbito da crítica literária destacamos André Luis Rodrigues, Augusto Massi, Estevão Azevedo, Leyla Perrone-Moisés e Masé Lemos. Valemo-nos de alguns instrumentos da psicanálise de Sigmund Freud e Jacques Lacan, conforme interpretações de alguns de seus comentadores. Algumas passagens e temas bíblicos assim como referências mitológicas artísticas foram empregadas livremente. Além da antropologia durandiana e da hermenêutica ricoeuriana, a fundamentação teórica e os aportes metodológicos contam com Gaston Bachelard, Edgar Morin e Michel Maffesoli no campo epistemológico e com Alberto Filipe Araújo, Jean Jacques Wunenburger, Marcos FerreiraSantos e Rogério de Almeida como desdobramentos interpretativos nos campos do imaginário

\footnotetext{
${ }^{5}$ É legitimo citar a tese "Lavoura arcaica e os símbolos do mal: uma leitura crítica da violência contra a mulher" (ABBOUD, 2017) que conosco partilha Ricoeur (2015), embora estabeleça outros critérios interpretativos. Destacamos que o trabalho não chegou ao nosso conhecimento em tempo de instaurarmos com ele um diálogo.
} 
articulado à educação. Fiamo-nos em Pierre Bayard, Gilles Deleuze, Antonio Cândido, Paulo Freire e no próprio Raduan Nassar para apontar o aspecto formativo da literatura e da leitura.

Como resultados apresentamos uma (est)ética formativa ancorada no aspecto performático do texto e na afirmação cotidiana do homem comum, experiências das quais sobressaem resquícios de liberdade radicados na potência da vida. Tais resultados são desenvolvidos ao longo dos capítulos de análise articulando a expressão fenomenológica do imaginário da queda no interior da literatura de Nassar com a interpretação crítica do potencial formativo de seus textos. Com isso, concluímos que o universo nassariano confere ao leitor um processo de deseducação ${ }^{6}$, já que desconstrói um conjunto de valores atrelados à razão e ao progresso moral, fundamentos da educação moderna.

Todas as citações de Nassar foram extraídas de sua Obra completa (2016). Para facilitar a leitura e a escrita suas obras serão descritas por siglas. Incluiremos nos parênteses a sigla após a página citada para identificar de qual livro ou conto é o trecho recortado, conforme apontado na Lista de Siglas. Cabe ressaltar, no entanto, que os nomes completos de livros e contos serão retomados quando julgarmos simplificar a leitura. As passagens sequenciais dos mesmos autores serão referenciadas apenas com as páginas correspondentes. No que se refere à escrita, adotamos o tom de ensaio.

Conforme o referencial teórico por nós adotado, o processo hermenêutico que aqui se apresenta é solidário do itinerário de (auto)formação deste que escreve, ao que tomamos a liberdade de incluir no início de cada um dos capítulos correspondentes às análises dos textos literários um conjunto de fotografias provenientes de arquivo familiar à guisa de traduzir em imagens as memórias que inspiraram esta pesquisa. Ao nomear estas fotografias empreguei excertos nassarianos sem utilizar aspas.

O primeiro capítulo deste trabalho expõe o enquadramento da nossa pesquisa no campo da educação recuperando para isso o potencial formativo da literatura e da leitura. Além disso, apresentamos a fundamentação teórica e os aportes metodológicos adotados. No segundo capítulo trazemos uma apreciação panorâmica de toda a obra de Raduan Nassar e uma aproximação de seus textos ao imaginário da queda. Na sequência, apresentamos estudos contemplando "Aí pelas três da tarde", "Mãozinhas de seda" e "A corrente do esforço humano".

\footnotetext{
${ }^{6}$ Mecanismos de buscas como o Catálogo de Teses e Dissertações da CAPES e o Google Acadêmico retornam diversos trabalhos a partir da entrada "deseducação", demonstrando vários espectros de análise com diferentes referenciais teóricos e múltiplas aplicações deste termo. Destacam-se seus usos no contexto das teorias pós-críticas, familiares nos campos da filosofia da educação, da cultura e do currículo. De maneira geral o termo se refere a processos de desconstrução em geral (interpretação por nós assumida), tendo especial conexão com o polissêmico conceito de experiência e sua utilização na literatura educacional. A tradução para o inglês também é variável, constando un-education, miseducation e dis-education, ao que optamos por esta última.
} 
No capítulo três abordamos "Menina a caminho", "O velho" e "Monsenhores". O capítulo quatro, por sua vez, abrange análises de "Hoje de madrugada", "O ventre seco" e Um copo de cólera. O quinto capítulo trata exclusivamente de Lavoura arcaica.

Todos os capítulos referentes aos textos nassarianos contêm uma apresentação diacrônica de cada um dos trabalhos abordados, incluindo na descrição comentários, críticas, interpretações e relações intertextuais. Em seguida, apresentamos um estudo sincrônico no qual as análises literárias são organizadas tematicamente, integrando discussões e interpelações de outras obras nassarianas. O agrupamento dos textos em cada uma das seções e subseções desta dissertação teve como critério a familiaridade temática que guardam entre si. 


\title{
1 ITINERÁRIOS DE INVESTIGAÇÃO POÉTICA
}

\author{
O fundamento de um pensamento é o pensamento de um \\ outro, o pensamento é o tijolo cimentado em um muro. É \\ um simulacro de pens amento se, no retorno que faz sobre \\ si mesmo, o ser que pensa vê um tijolo livre e não o preço \\ que lhe custa essa aparência de liberdade: ele não vê os \\ terrenos baldios e os amontoados de detritos a que uma \\ vaidade suscetível o abandona com seu tijolo [...] nesse \\ lugar de ajuntamento, onde a violência impera, no limite do \\ que escapa da coesão, aquele que reflete na coesão percebe \\ que não há mais lugar para ele. \\ - Georges Bataille. Teoria da religião.
}

Neste capítulo construímos nossa fundamentação teórica e apresentamos nossa metodologia de pesquisa. Discutiremos o aspecto formativo da literatura, a leitura como itinerário de (auto)formação e apresentaremos a antropologia do imaginário e a hermenêutica simbólica como recursos e instrumentos interpretativos.

\subsection{UMA COMPREENSÃO FORMATIVA DA LEITURA E DA LITERATURA}

As relações entre educação e cultura articulam um intenso diálogo entre saberes no bojo das humanidades e das artes, mobilizando aspectos convergentes de diversos campos. Pensar as produções culturais em seu potencial formativo exige, de largada, rechaçar a hegemonia contemporânea da escola como instituição formativa e, ao mesmo tempo, deslocar o olhar pedagógico do instrumental tecnocrático das metodologias de ensino (como fazer) para se debruçar em itinerários de formação que se fazem no plano informal, de modo artesanal e orgânico, conquanto as experiências de arte e cultura atravessam os sujeitos ao longo de suas vidas. Nessa direção, as perguntas de pesquisa assumem a dimensão da infinidade de questões suscitadas pela cultura humana, distribuída fartamente em vivências e objetos culturais de toda sorte, o que permite à literatura figurar no quadrante desta dissertação.

Ao pensarmos em itinerários de (auto)formação, pressupomos a existência de um percurso formativo intenso e significativo que se dá aquém, além e apesar da escola. Há um processo educativo amplo que se realiza com e na cultura, ao olharmos para a música, o teatro, os saraus, a literatura, o cinema etc. Os itinerários de (auto)formação abrem a educação para a diversidades de saberes e disposições apropriados e manifestos na própria vida. Os itinerários 
formativos ressaltam que a educação tem valor em si e que a vida supera a ideologia, as instituições, os programas e transcende teorias e métodos na pulsação do cotidiano.

O conceito de itinerários de (auto)formação ${ }^{7}$ é desenvolvido com precisão em verbete correspondente na obra Aproximações ao imaginário: bússola de investigação poética (FERREIRA-SANTOS; ALMEIDA, 2012). Não obstante, uma compreensão ampliada destes itinerários de formação através da cultura é apresentada no capítulo "Humanitas: a educação entre as estruturas de poder e a potência existencial" da obra Antropolíticas da educação (2011), dos mesmos autores. Há algumas convergências com os complexos conceitos de Paideia grega, Humanitas latina e Bildung alemã (de onde provém o termo bildungsroman, romance de formação), discutidos tanto nesta última obra quanto na tese de livre-docência de Rogério de Almeida, O mundo, os homens e suas obras: filosofia trágica e pedagogia da escolha (2015). Além disso, Almeida (2013) sugere uma "aprendizagem de desaprender" como itinerário de formação sustentado na filosofia trágica (NIETZSCHE, 2005; ROSSET, 2010) e na pedagogia da escolha. De maneira análoga, propomos nesta dissertação uma educação pela deseducação, desconstruindo e questionando fundamentos da educação moderna.

A escola como epicentro de nossas preocupações acaba por recortar a questão educacional na eficiência e efetividade de um sistema de educação, no bojo das políticas educacionais de Estado e das práticas de mercado, em um movimento que Marcos-Ferreira Santos e Rogério de Almeida batizaram "escolacentrismo" (FERREIRA-SANTOS; ALMEIDA, 2011). Recusar o escolacentrismo vigente implica romper com modelos restritos de subjetivação, à guisa de multiplicar modos de ser e estar no mundo, fruindo e criando cultura. A educação na cultura demanda a constante (re)invenção de si, mediante as experiências e vivências que nos atravessam, perfazendo uma experiência curricular alheia às grades e programas, de modo que neste caminho tão pessoal quanto coletivo seja possível rearticular a interlocução com os cânones de toda ordem.

A ideia de formação humana relativiza a centralidade da escola na formação, reintroduzindo os valores na constituição dos fenômenos educacionais. A vida nos entrega princípios como coragem, valentia, niilismo, prazer, bondade, beleza, sem predizer a medida e forma como devemos lançar mão destes vícios e virtudes. Da mesma maneira, tampouco nos é clara a finalidade da vida, o que transpõe à educação o desafio de criar pessoas e comunidades

\footnotetext{
${ }^{7}$ Note-se que o termo (auto) complementa a noção de um caminho formativo aberto, livre e informal em que o próprio sujeito ressignifica suas experiências e vivências com o conhecimento a medida que percorre seus desafios, em que pesa nesta definição o valor da cultura e das artes. Não obstante, em alguns momentos esse termo será omitido preservado a dinâmica do texto e ressaltando que estas trilhas pessoais não são exclusivas do sujeito, mas partilhadas pelos contextos coletivos em que esta pessoa se insere, incluindo-se as instituições de educação formal.
} 
vindouras, seja para o desenvolvimento do pensamento crítico e da atitude cidadã, como preconiza a legislação educacional, seja na construção do sujeito empreendedor, como sonha o empresariado, seja na transmissão dos valores e saberes historicamente construídos, como a tradição e o currículo humanista postulam. Pensar a educação, portanto, implica a disposição para um espírito filosófico que, por sua vez, convém acrescentar uma atitude antropológica:

em toda Filosofia, seja de que tipo, resta uma antropologia [...] não é possível estabelecer qualquer discurso, ou mesmo enunciar a proposição que se queira, sem antes (no sentido de uma anterioridade condicionante, subjacente ao que se diz), lançar mão de uma imagem ou ideia do Homem (PAGOTTO-EUZEBIO; ALMEIDA, 2012, p. 7, grifo nosso).

$\mathrm{O}$ rastreamento das imagens de homem e de mundo nos produtos da cultura e na literatura abre caminho para uma hermenêutica ${ }^{8}$ simbólica. Não obstante, o nascedouro deste caminho e sua aproximação com a educação advêm de um olhar transdisciplinar que se gesta num adagio sinuoso entre antropologia e um cabedal de saberes que se investem na interpretação do fenômeno educacional, sob o amparo da filosofia da educação:

\begin{abstract}
a filosofia da educação constitui-se como antropologia filosófica, como tentativa de integração dos conteúdos das ciências humanas, na busca de uma visão integrada do homem. Nessa tarefa ela é, pois, reflexão eminentemente antropológica e, como tal, põe-se como alicerce fundante de todas as demais tarefas que lhe cabem. Mas não basta enunciar as coisas desta maneira, reiterando a fórmula universal de que não se pode tratar da educação a não ser a partir de uma imagem do homem e da sociedade. A dificuldade está justamente no modo de elaboração dessa imagem (SEVERINO, 1990, p. 20).
\end{abstract}

Assim sendo, partimos do pressuposto de que a atividade interpretativa dos fenômenos culturais, bem como seu desdobramento nas produções culturais, como o é a literatura, demanda tanto critérios objetivos, na partilha científica comum dos saberes acadêmicos, quanto critérios subjetivos, para os quais converge o itinerário de formação do próprio intérprete e de seu contexto de interpretação. Nesse caso, para nossa abordagem convergem aspectos

\footnotetext{
8 A hermenêutica é um "ramo da filosofia que se ocupa da interpretação de textos e discursos [...] busca compreender, interpretar, traduzir o sentido de uma obra. Tem sua fundamentação teórica formulada por Friedrich Schleiermacher (1768-1834), que busca estabelecer uma teoria geral da compreensão, pela qual não podemos compreender o todo sem que se compreenda suas partes e vice-versa. Esse procedimento é chamado de círculo hermenêutico" (FERREIRA-SANTOS; ALMEIDA, 2012, p. 106). A dicotomia entre o distanciamento objetivo e a proximidade subjetiva, tal como problematizou Gadamer (1997), é superada por Ricoeur (2008), ao sustentar que o texto é autônomo, é uma proposição de mundo. Dito de outro modo, a leitura sempre se dá a partir de um distanciamento, já que tanto o escritor toma distância de seu texto quanto o leitor também o faz, frustrando a possibilidade de se conquistar uma objetividade estrutural do texto ou uma suposta intenção do escritor ao escrevêlo. Desse modo, não nos cabe procurar o que estaria atrás do texto, mas o que se mostra diante dele como mundo possível a partir do qual estabelecemos um diálogo com o nosso mundo.
} 
transdisciplinares que incidem na apropriação do texto por diversos autores de áreas alheias à teoria e crítica literária, sem dispensar a interlocução com intérpretes de diferentes segmentos das letras. Investimos, por conseguinte, em uma antropologia simbólica e nos direcionamos à uma perspectiva que valoriza a pregnância simbólica, delegando ao imaginário a condição de proposição de conhecimento. Este posicionamento se imprime na reabilitação da sensibilidade no concurso do saber, à guisa de uma razão sensível (MAFFESOLI, 1998).

A "educação de sensibilidade" (FERREIRA-SANTOS, 2004) estabelece uma relação intensa com as artes, mobilizando os sentidos na criação, na interpretação e na contemplação das obras humanas. A sensibilidade perscruta o enigma cotidiano, se manifesta na intuição, na metáfora e, também, no senso comum (MAFFESOLI, 1998). Abrimos o significado simbólico às experiências e vivências humanas permeadas pelo percurso formativo deste que aqui escreve: "exercício constante da configuração do campo perceptivo, com o refinamento de todos os sentidos e sua reversibilidade para a transfiguração de uma determinada estrutura de ser, através da experimentação, da dialogia e da escuta atenta" (FERREIRA-SANTOS, 2010, p. 77). Portanto, o percurso formativo, na educação de sensibilidade, é indissociável da criação de si, apanágio do "torna-te quem tu és" de Píndaro. Não obstante, este percurso formativo constitui senão itinerários de (auto)formação. Rogério de Almeida (2013) concebe os itinerários de formação no contexto da filosofia trágica:

a educação no registro trágico - que equivale filosoficamente a pedagogia da escolha, aprendizagem de desaprender ou itinerário de formação - resume-se a dois principais objetivos: 1) pôr em evidência o real (sua condição trágica, insignificante, o acaso da existência), isto é, fazê-lo falar, dar expressividade poética, filosófica, tautológica, literária, simbólica, imaginária, estética etc.; e 2) gozar a alegria da aprovação incondicional do real, ou seja, celebrar a existência inclusive em seus aspectos mais dolorosos, desagradáveis e indigestos, não porque haja algum tipo de prazer na dor, mas pela condição mesma de uma aprovação incondicional, que consiste em, ao afirmar a vida, afirmá-la integralmente (ALMEIDA, 2013, p. 1013).

A pedagogia da escolha, de Rogério de Almeida (2013; 2015), fundamenta-se no pensamento de Clément Rosset (2010), conforme o qual a condição humana é marcada pelo trágico9; ou seja, o nada, o acaso e a convenção são os princípios da existência. Nessa direção, o ser humano pode aprovar ou não a vida integralmente. A lógica do pior implica a aprovação incondicional da vida, mesmo diante do pior dos mundos (ROSSET, 1989). A negação da vida

\footnotetext{
${ }^{9} \mathrm{O}$ trágico assume diversas conotações nos campos da filosofia e das letras em diferentes contextos e de acordo com a interpretação de diferentes autores. A obra de Nassar dialoga com ao menos três possibilidades: a) gênero dramático forjado na Antiguidade; b) niilismo nietzscheano pela transmutação dos valores; c) afirmação incondicional da vida. Nesta dissertação utilizaremos o termo sem referência no primeiro caso, referenciando Nietzsche no segundo e Rosset no terceiro. Para mais detalhes consultar Almeida (2015b).
} 
se manifesta na ideologia, na ilusão, pois condiciona o real; em outras palavras, cria um duplo ilusório, condicionado às expectativas e princípios de quem o formula (ROSSET, 2008).

O mundo tal como se apresenta circunscreve-se na implacabilidade do destino, no concurso do trágico (ROSSET, 2010). A projeção de uma felicidade futura, na salvação extraterrena ou num mundo que está por vir - seja pela transformação da sociedade/mundo, seja pela transformação do ser - duplica o real, formula uma ilusão. Vive-se sob a condição de que o mundo possa vir a ser mais justo ou se mostre, à maneira da ilusão, menos cruel e terrível. Isto é, a não aprovação da vida incorre na assunção de um telos ou em uma lente de proteção que condiciona e duplica o real - por isso, aprovação condicional. Nesse caso, nossos valores (condicionantes) são uma convenção. Convenciona-se e condiciona-se o real. A escolha da aprovação integral, ao que habilita a multiplicidade de modos de existir, não encerra o ser em uma formula desejável, não encerra a educação em uma finalidade única e obtusa. A aprovação suspende a formulação pedagógica como valores determinados por valores múltiplos a serem construídos, rastreados e confrontados nas produções simbólicas.

A pedagogia da escolha (ALMEIDA, 2015) possibilita-nos pensar a existência como aprovação da vida, como amor fati, presente de modo intermitente no universo nassariano: “minha fórmula para a grandeza no homem é amor fati: nada querer diferente, seja para trás, seja para frente, seja em toda a eternidade. Não apenas suportar o necessário, menos ainda ocultá-lo [...], mas amá-lo" (NIETZSCHE, 1995, p. 9). Nesse caso, esta dissertação se presta a manifestar o amor de quem aqui escreve pela arte de um Raduan Nassar que recusa o aprimoramento da espécie humana, recusa sua própria literatura e os eventuais ganhos que a leitura poderia conferir ao homem. Porém, a recusa nassariana vem acompanhada de um riso de escárnio, uma alegria marota que perfaz suas polêmicas declarações públicas e seus atabalhoados personagens.

Da deseducação nassariana se impõe a beleza performática de seus textos e sua apologia ao caráter singelo e frívolo da vida. Assim, a indiferença trágica da aprovação da vida (ROSSET, 2010) convive com as diferenças dramáticas das relações humanas, fazendo do conflito de valores, como agonística de forças simbólicas, um traço deste jogo terreno que se repete ciclicamente. Desse modo, amar o próprio destino é amar a balburdia que nos consome, viver tão bem, tão certo e tão intensamente, como se fossemos retornar indefinidamente para esta mesma vida: 
não somente para si, mas para a peça inteira, para todo o espetáculo, e não apenas para um espetáculo, mas, fundamentalmente, para aquele que necessita exatamente desse espetáculo e o torna necessário, porque sempre de novo precisa de si mesmo, e o faz necessário (NIETZSCHE, 2005, p. 81).

A construção de si conduz à beleza do eterno instante. Este presente, este instante precioso, é amor ao destino, afirmação da vida. Se se fosse viver eternamente a mesma vida o que se faria a cada instante? Instala-se a vida tal como o trágico (NIETZSCHE, 2005): o instante eterno e risonho da $\operatorname{arte}^{10}$. Portanto, a configuração de si na diferença é condição para uma educação assentada na dimensão estética da vida: "que não mais se separe a arte da vida ou, antes, para retomar uma fórmula comum, que a vida seja vivida, conscientemente ou não, como uma obra de arte" (MAFFESOLI, 1998, p. 150). A dimensão estética da vida conduz, além da reintrodução da sensibilidade, do símbolo e do imaginário no conhecimento, em recuperação da componente erótica do saber, de um saber erótico, como aponta Maffesoli (1998, p. 14). Existe sedução no conhecimento, uma componente erótica fundamental na consideração do saber sensível:

seja pela busca da verdade, fundamentada pela crença metafísica em sua existência, pela retórica ou discurso, o fato é que a sedução pela linguagem sempre implicará no rapto da alma. Como no amor, é possível que nos campos filosófico e pedagógico ela se exerça delicadamente, sorrateiramente, criando o impulso apaixonado da alma pelo conhecimento (DOZOL, 2007, p. 321).

Nessa direção, a compreensão do texto literário se faz tão ou mais viva quando confrontada com as paixões do leitor ${ }^{11}$, este que incute nos textos pelos quais transita uma poética da leitura (QUEIROGA, 2013). A leitura se manifesta no leitor a partir do impulso de vida presente nos livros. O gesto de criação de mundos da literatura converge ao devaneio, ao transe, ao delírio. O universo dos textos literários nos atravessa como possibilidade de (auto) criação.

\footnotetext{
${ }^{10}$ O conceito de "repetição" aparece também em Deleuze (1988) como repetição da diferença, o que se repete é a diferença, como no rio de Heráclito.

${ }^{11}$ Convém citar a contribuição de Wolfgang Iser (1999), quando indica que "a constituição de sentido e a do sujeito-leitor são duas operações entrelaçadas nos aspectos textuais" (p. 83). Para Iser a cisão entre o texto e o leitor deixa de operar como separação entre objeto e sujeito, abrindo àquele que lê um horizonte de alteridade que o permite conviver com a experiência de outrem, imiscuída entre a criação do escritor e a performance ficcional. Nesse caso, "a constituição de sentido que acontece na leitura [...] não só significa que criamos o horizonte de sentido, tal como implicado pelos aspectos do texto; ademais, a formulação do não-formulado abarca a possibilidade de nos formularmos e de descobrir o que até esse momento parecia subtrair-se à nossa consciência. Neste sentido, a literatura oferece a oportunidade de formularmo-nos a nós mesmos, formulando o não-dito" (p. 93).
} 
a literatura é delírio, mas o delírio não é um assunto de pai-mãe: não há delírio que não passe pelos povos, pelas raças e as tribos, e que não habite a história universal. [...] O delírio é uma doença, a doença por excelência, quando erige uma raça que se pretende pura e dominante. Mas ele é a medida da saúde quando invoca essa raça bastarda oprimida, que não para de se agitar sob as dominações, de resistir a tudo o que esmaga e aprisiona, e de se esboçar enquanto fundo na literatura como processo (DELEUZE, 2006, p. 6).

O texto literário dá visibilidade aos anônimos, valoriza o instante, o cotidiano, a vida, suas nuances e contradições. Diante da potência de vida, Antonio Candido (2002) qualifica a literatura como força humanizadora, entendendo-a como direito fundamental do homem (CANDIDO, 1995). Justamente por multiplicar e vivificar o homem - várias imagens de homem - a literatura fala, também, com todos os homens, senão com os homens de determinada cultura ou determinado segmento social. Em outra direção, a literatura não precisa se encerrar no âmbito da cultura erudita: "a música de Mozart não é burguesa; a grande injustiça está em que só a burguesia frua dessa música. O verdadeiro meio de suprimir o escândalo não é denunciar a cultura como burguesa e, sim, fazer que já não o seja, abri-la a todos os homens" (REBOUL, 1988, p. 23).

Consideremos que a escrita e a leitura de ficções têm lugar nos mais diferentes contextos sociais e econômicos. Nos saraus, por exemplo, a palavra se transmuta em verso e a poesia, e em sua forma falada recupera a dimensão estética da vida. Trata-se da vivificação dos modos de existir e de se expressar em suas variações. Raduan Nassar, em entrevista a Edla Van Steen, em 1983, ao ser questionado sobre as tiragens editoriais de três mil cópias num país, à época, com 120 milhões de habitantes, responde:

Se esses 120 milhões de habitantes se sentem felizes, não teria nada a opor, absolutamente nada, afinal, a que viria o incremento da leitura num caso assim? Se não se sentem felizes, resta saber se o problema da felicidade seria resolvido aumentando a tiragem dos livros. Seja como for, seria interessante consultar os 120 milhões a respeito, mas desconfio que a maioria iria preferir um aumento substancial de salários (NASSAR, 1983, p. 102).

O desdém em relação à literatura e seu potencial é característica marcante das intervenções de Nassar, que pensa a literatura como uma questão pessoal, a passo que considera a construção de um pensamento próprio como finalidade possível para a educação. Raduan crê que a literatura "não tem função social nenhuma" (NASSAR, 1992, p. 4). Em seu desprezo pelo status quo, o escritor qualifica e dimensiona a potência do leitor (e do escritor) independente: 
exclusivíssima de cada escritor, não existe nenhuma Convenção de Genebra regulamentando o assunto, apesar dos supostos convencionais [...] seria bom lembrar também que a apreciação de um texto é do domínio exclusivíssimo de cada leitor, e só dele [...] nada pode contra a soberania do leitor, quando essa soberania, está claro, é conquistada, o que é raro. Pro leitor independente, que não tem vocação para obediência, as autoridades no assunto perdem a existência (NASSAR, 1983, p. 102103, grifo nosso).

Manifesta-se em Raduan Nassar um desdém pela teoria literária e um desprezo pela crítica. Raduan concebe a literatura como manifestação visceral, radicada na experiência e na vivência, valorizadas desde sua juventude como coração do texto literário, em detrimento de escolas ou tendências estéticas:

E que diabo, a literatura sem vínculos com a vida não é nada! E ficam estas escolinhas lambendo o saco de Joyce e de Pound! E que diabo, ninguém tem coragem de dizer que não aguenta "Finnegans Wake", e que Pound tem doze poemas bons! E eu não consigo ler Oswald de Andrade e esta divisão Mário versus Oswald já existe há trinta séculos! E eu não tenho a coragem de dizer que não li Guimarães Rosa pra me proteger, pois ele não é da minha praia, e puta que o pariu, fiz meus dois textinhos sem levar em conta a zoeira aí fora, fiz lirismo quando o lirismo estava fora de moda e puta que pariu! [...] e demônios! a pretexto de seguir a modernidade, os escritores acabam por bloquear o seu talento específico e [...] e cacete!, ficam obedecendo os teóricos e as regrinhas! E a liberdade é uma das poucas coisinhas boas que a vida nos dá, e sem a experiência vivida a literatura não é nada, e toda concepção literária não é maior do que a vida (NASSAR, 1992b, p. 5, grifo nosso).

É justamente a liberdade do texto o que dá força ao universo literário de Raduan. O texto como liberdade, o texto como experiência de conformação e superação do mundo. Embora suas imagens de homem nos remetam a um mundo distópico e sem solução redentora, a violência lírica de seus textos ressalta o aspecto dionisíaco da vontade ${ }^{12}$, ora recobrando a performance (est)ética da literatura, ora radicando a expressividade no silêncio cotidiano do homem comum. Ressalte-se também a conexão da literatura com a vida e com a formação, que atravessa as intervenções do autor em suas entrevistas. Um dos momentos mais significativos nesse sentido é a comparação entre os livros e o Livrão da vida na entrevista que dá aos Cadernos de Literatura Brasileira:

E tem isso: a leitura que mais eu procurava fazer era a do livrão que todos temos diante dos olhos, quero dizer, a vida acontecendo fora dos livros [...] Agora, apesar da importância que eu punha na leitura do Livrão (Livrão com maiúscula), é certo que muito do meu aprendizado foi feito também em cima de livros, especialmente de uns

\footnotetext{
${ }^{12}$ A imbricação entre vontade de potência e o dionisíaco em Nietzsche, porventura, favorece a emergência da imaginação simbólica: “enquanto, no estado apolíneo, o homem joga com a realidade, no estado dionisíaco, ou de embriaguez, ele joga com a vontade ou com a própria natureza que nele se revela. Nesse estado de emoção, o artista dionisíaco é levado ao paroxismo de suas faculdades simbólicas; a natureza o força a exprimir-se, a dominar o caos da vontade e a criar um novo mundo de símbolos onde se encontram a dança e a música" (DIAS, 2015, p. 230, grifo nosso).
} 
poucos autores, autores que iam ao encontro das minhas inquietações, mas não me pergunte quais que já não me lembro [...] digamos que eu punha um olho nos livros, e um Olhão fora dos livros (NASSAR, 1996, p. 27, grifo nosso).

Ao tratar de sua formação como escritor, Nassar equipara senão prioriza a experiência vivida aos próprios livros. Não significa excluir os livros, mas compreender que o grande ato de arte é a vida em si e que o texto literário pode transmitir a potência de vida na palavra escrita. Ao ser perguntado, por Mario Sabino, sobre o ensino de literatura nas escolas, Raduan evoca outra dimensão sobre o que pensa de literatura e formação:

desconfio que ela não deveria ser ensinada como vem sendo. De um modo geral, acho que os professores transferem para os alunos gostos e critérios pessoais, o que acaba formando um rebanho destinado a adorar certos nomes. Talvez se devesse treinar o aluno a pensar com a própria cabeça, a ser ele mesmo na sua relação com as leituras - supondo-se, é claro, que o professor conseguisse pensar com sua própria cabeça (NASSAR, 1997b, p. 10).

Independência de pensamento e autonomia de leitura são tônicas de Raduan quando questionado acerca da literatura no contexto escolar. Para Nassar a força da literatura está na realização pessoal, tanto do escritor como do leitor. Segundo o autor, a finalidade do texto literário seria ludibriar a própria existência:

\begin{abstract}
Para quem faz, se ocupar em fazer. Para quem lê, se ocupar em ler. As duas ocupações seriam bons recursos para ludibriar a existência, o que não é pouco, sobretudo se se tratar de uma literatura portadora de reflexão sobre a vida. Escritores e leitores de uma literatura assim à parte da espécie que não consegue se ajustar a esse mundo. Uns e outros sairiam de sua solidão na medida em que a leitura promoveria um encontro entre eles. Agora, do ponto de vista de uma função social mais ampla, não consigo enxergar nada com clareza. Pode até ser uma grande inutilidade (NASSAR, 1997, p. $10)$.
\end{abstract}

A literatura é uma realização humana desinteressada, não corresponde a nenhuma finalidade definida, sobretudo na esfera pragmática. É justamente o que garante seu potencial de formação e sua capacidade de engendrar o ser para que possa viver a vida como arte. É nesse mundo particular que Raduan nos convoca para a existência que nos quer demonstrar. Tratando de experiências em sua terra natal, Pindorama, Raduan retoma a potência do particular:

Aconteceu um dia de eu olhar para um colega pobre que, por sua vez, olhava fixo o pai, embriagado, ser surrado em público por outro homem. O que vi nesse rosto é indescritível, nunca esqueci nem vou esquecer. Nada me marcou mais do que isso. Fui ler mais tarde a mesma cena em Dostoievski. Daí dizem - quem descreve bem a sua aldeia está falando do mundo (NASSAR, 1998, p. 5). 
Quem descreve bem um homem está falando de toda a espécie. A vontade conflitante, a sexualidade ambígua, a violência, são aspectos da aldeia de Raduan Nassar. O transe, o narcisismo, o drama, a ancestralidade judaico-cristã e árabe. Sua aldeia é o ser irrequieto e sua circunvolução agônica. Além disso, o homem distópico de Nassar dialoga com a condição pósmoderna, a despeito de Raduan ter declarado não apreensão do conceito de "pós-moderno" na entrevista concedida aos Cadernos de Literatura Brasileira (NASSAR, 1996).

Em outra direção, o apelo à leitura da vida (Livrão) remete à fundamentação de Paulo Freire (2003). Conforme o pensamento freireano, o letramento começa na leitura de mundo. Dar vida aos signos é imprimir sentido à vida sob o pretexto de compreender o funcionamento e o uso da língua. Vivenciando a leitura e a escrita, o sujeito mobiliza sua leitura de mundo, constituindo um diálogo entre o mundo e a palavra, num sentido libertador e revolucionário. Já a liberdade para Raduan significa construir o mundo do texto, é a liberdade do texto. Assim como Freire, a leitura da vida viabiliza o texto, mas ao contrário da experiência emancipadora do pensamento freireano, a literatura de Nassar não crê em nenhuma redenção.

No universo nassariano, a mudança só ocorre como manifestação da vontade, como dinamismo de um desejo irracional, nunca como projeto de sociedade. Não obstante, a liberdade no texto é o que possibilita a entrega e a experiência da dimensão estética da vida: "os temas que elegemos, o repertório de palavras que usamos, além de outros componentes da escrita, tudo isso passa pela triagem dos nossos afetos. A literatura não precisa rastrear as ciências exatas, nem vejo como, literatura é outro papo" (NASSAR, 1996, p. 37). Fortalecendo a componente humana da literatura, reencontramos o delírio como motivador do texto. O delírio é o que nos permite aproximar Raduan da crítica às abordagens instrumentais da educação. Ele comenta o estado de coisas reabilitando a sensibilidade pela manifestação do delírio:

a chamada modernidade no sistema de produção, com sua ênfase na eficiência, vinha esmagando certas manifestações de humanismo, incluindo-se nesse humanismo o delírio de alguns. Só pra se ter uma ideia, já disseram que o conceito de solidariedade não será mais entendido pelas novas gerações do próximo milênio (NASSAR, 1996, p. 28).

No plano contemporâneo se dá a marginalização da utopia. Por outro lado, no texto literário e nas manifestações de arte essa utopia pode ser recuperada como topos literário, alimento da sede de justiça. Na contemporaneidade vivemos um frenesi técnico-administrativo, o empresariamento do mundo, porém, a despeito da tecnocracia vigente, sobrevive o espírito de Dioniso, marginal. 
Quando as formas de controle da individualidade se aprimoram, impossível imaginar hoje o que acontecia antigamente num cais de porto. Um anônimo qualquer, em troca de trabalho, embarcava num navio com destino desconhecido, sem qualquer formalidade burocrática. Esses instantes de sentimento de evasão, de delírio, de angústia exasperada em relação a uma ordem que enquadra e oprime, esses instantes ainda não abandonaram nosso imaginário (NASSAR, 1996, p. 37).

O delírio levou Nassar para a literatura em sua juventude, como comenta Modesto Carone (NASSAR, 1996), episódio em que Hamilton Trevisan, José Carlos Abbate e Raduan Nassar tentam embarcar clandestinamente em um navio no porto de Santos para que pudessem voltar com suas "obras prontas". Recuperando as posições de Nassar frente a literatura, sua obscura trajetória de formação como escritor, as múltiplas referências que o escritor emprega em seus textos e o confronto da literatura nassariana com o cenário contemporâneo, tornandoa cada vez mais atual, entendemos que o delírio não suspende nem substitui a razão, mas dá tônus à nossa compreensão de mundo e de nós próprios, fazendo de Raduan Nassar, um autor que demanda o investimento de várias frentes de análise para que suas vicissitudes possam ser contempladas e confrontadas com outras obras, outras áreas de pesquisa e outras formas de pensamento e concepção de mundo. Ante as possibilidades múltiplas de construção de valores, a literatura como formação se constitui através de fragmentos e recortes de uma leitura interrompida. Assim sendo, podemos pensar a leitura como recuperação do delírio na banalidade do cotidiano.

\subsection{ESCRILEITURAS INTERROMPIDAS}

Ao pensarmos a literatura como formação lançamos mão de uma compreensão antropológica dos textos literários, estribada em uma hermenêutica capaz de reabilitar a imaginação simbólica como forma de conhecimento. Segundo Paul Ricoeur, o escritor "encontra o homem já instalado a título preliminar no interior do seu fundamento" (RICOEUR, 2015, p. 374), o que confere à criação literária o estatuto de enunciação de imagens de homem e de mundo através das quais permite um diálogo complexo com seus leitores. Nesse caso, a pletora de emanações simbólicas que provém do homem sustenta o traçado das palavras imiscuindo na criação textual a própria atividade de leitura.

Não obstante, a leitura e a escrita convergem para a mesma equilibração simbólica que a eufemização diluída dos sentimentos e emoções humanas nas produções culturais oferece, mediante o excesso de verdade que há no mundo. Assim sendo, "todo livro angustiante pode então proporcionar uma técnica de redução da angústia. Um livro angustiante oferece aos 
angustiados uma homeopatia da angústia" (BACHELARD, 2009, p. 25). Ao dissipar a angustia existencial a leitura desvenda o homem, mobilizando imagens e a metáforas que compõem sua condição inextricável diante da própria vida. Nesse caso, o objeto-livro permite ao leitor adentrar na volúpia criativa do universo de outrem:

O livro é permanente, está sob os nossos olhos como um objeto. Ele nos fala com uma autoridade monótona que seu próprio autor não teria. Temos de ler o que está escrito. Para escrever, aliás, já o autor operou uma transposição. Ele não diria aquilo que escreve. Adentrou [...] no reino do psiquismo escrito (BACHELARD, 2009, p. 24).

Nessa direção, o livro se apresenta como um objeto do corpo, referente ao corpo de quem digeriu a materialidade das suas metáforas. Assim, o livro passa a ser o corpo cindido do escritor: odores, tonalidades, texturas, formatos, sabores, um solo profundo vertido em húmus. Projetando a verdade do discurso na materialidade corporal das palavras, como mostrou Estevão Azevedo (2015) interpretando a obra de Raduan Nassar, o livro se insere em um lapso entre as verdades desveladas entre a interioridade discursiva de quem lê e a exterioridade inapreensível do ambiente externo, "constitui ao mesmo tempo uma realidade do virtual e uma virtualidade do real” (BACHELARD, 2009, p. 25). É preciso acolher o livro, não só recebê-lo através dos olhos. É preciso comê-lo. As imagens que se mostram durante esta digestão são amparadas pelo arcabouço da memória:

os poetas abundam, os grandes e os pequenos, os célebres e os obscuros, os que amamos e os que fascinam. Quem vive para a poesia deve ler tudo. Quantas vezes, de uma simples brochura, jorrou para mim a luz de uma imagem nova! Quando aceitamos ser animados por imagens novas, descobrimos irisações nas imagens dos velhos livros (BACHELARD, 2009, p. 25-26).

Convém buscarmos as forças de onde provém essa anima-ção. Na psicologia das profundezas de Jung antevemos o animus masculino e a anima feminina, forças que compõem o imaginário e o mundo dos símbolos. Forças complementares que animam o mundo mantendo seu tensionamento. O animus é a constituição do masculino na psique da mulher, já que está "voltado às intimações do mundo e seus esquemas, respectivamente, de intervenção, apropriação, produção de conhecimento, busca da verdade, separação e conquista" (FERREIRA-SANTOS; ALMEIDA, 2011, p. 80). Por outro lado, a anima, na definição de Jung é: 
irracional, a capacidade de amar, a sensibilidade à natureza e, por fim, mas nem por isso menos importante, o relacionamento com o inconsciente (JUNG, 2008, p. 177).

Nesse caso, o apelo da literatura ao inconsciente dispõe no leitor um trajeto em que a anima toma conta de seus sentimentos e sensações, alvoroçando sua formação primeva desde que a potência das palavras a sua frente revele sua circulação sanguínea. Não obstante, o delírio age em conluio com o devaneio poético, permitindo ao leitor um arrebatamento nos instantes de leitura, sem com isso recorrer ao transcendental para que isso ocorra. Ali mesmo, no ato de leitura, se dá a intensa modificação formativa, não sendo revelado senão aquilo que lá no texto e no próprio sujeito sempre esteve, tão evidente quanto somente uma escrita singular pode suscitar:

nos nossos devaneios, na grande solidão dos nossos devaneios, quando a nossa libertação é tão profunda que já não pensamos sequer nas rivalidades virtuais, toda a nossa alma se impregna das influências da anima. E eis-nos no centro da tese que queremos defender [...]: o devaneio está sob o signo da anima. Quando o devaneio é realmente profundo, o ente que vem sonhar em nós é a nossa anima (BACHELARD, 2009, p. 58-59).

A força terral que nos acompanha, solidária de uma intimidade sagrada, nos impõe o sonho, a criação e o mistério do texto, convocando para o plano da realidade comum os sonhos e delírios distantes. Notadamente, há na leitura uma feminilidade se projetando, o que impõe a "necessidade de colocar no feminino tudo o que há de envolvente e de suave para além dos termos simplesmente masculinos que designam nossos estados de alma" (p. 27). Dito de outro modo, sob o regramento de forças masculinas que compõe o mundo produtivo do cotidiano, a leitura convoca mensageiros cuja latência demanda um significativo espectro de feminilidade, que faz do texto lido e escrito uma realização de razão sensível. A verdade do livro instala no leitor uma verdade incompleta. A história do leitor com o livro é a estória de como se engendra a vida no mundo. A vida tem com os livros um embaralhar que se materializa no alegre e erótico saber da experiência cotidiana. A espiral se retroalimenta entre a escrita, a leitura, o livro, a vida e o conhecimento em um movimento recursivo.

O princípio do circuito recursivo ultrapassa a noção de regulação com as de autoprodução e auto-organização. É um circuito gerador em que os produtos e os efeitos são, eles mesmos, produtores e causadores daquilo que os produz. Assim, nós, indivíduos, somos os produtores de um sistema de reprodução que vem do início dos tempos, mas esse sistema não pode se reproduzir se nós mesmos não nos tornarmos produtores com o acasalamento. Os indivíduos humanos produzem a sociedade nas interações e pelas interações, mas a sociedade, à mediada que emerge, produz a humanidade desses indivíduos, fornecendo-lhes a linguagem e a cultura (MORIN, 2010, p. 95). 
O saber complexo de Edgar Morin anima nossa compreensão da literatura. Tem-se os livros, o escritor, a crítica, o contexto social, econômico e histórico, o estatuto do conhecimento, o espírito do tempo e suas circunvoluções estéticas. Os recursos que empregamos para deslindar as imagens de homem em determinado autor se regulam mediante a recursividade moriniana e as ferramentas oferecidas por um saber sensível e complexo. Recupere-se, assim, o significado do método de Morin:

\begin{abstract}
Trata-se de um método capaz de absorver, conviver e dialogar com a "incerteza"; de tratar da "recursividade e dialogia" que movem os sistemas complexos; de reintroduzir o objeto no seu contexto, isto é, de reconhecer a relação parte-todo, conforme uma configuração "hologramática"; de considerar a "unidade na diversidade" e a "diversidade na unidade"; de distinguir, "sem separar nem opor"; de reconhecer a simbiose, a complementaridade e, por vezes, mesmo a hibridação, entre ordem e desordem, padrão e desvio, repetição e bifurcação, que subjazem aos domínios da matéria, da vida, do pensamento e das construções sociais; de "tratar do paradoxo" como uma expressão de resistência ao dualismo disjuntor e, portanto, como foco de "emergências" criadoras e imprevisíveis; de introduzir o sujeito no conhecimento, o observador na realidade; de "religar", sem fundir, ciência, arte, filosofia e espiritualidade, tanto quanto vida e ideias, ética e estética, ciência e política, saber e fazer (ALMEIDA, 2004, p. 15, grifo nosso).
\end{abstract}

Pierre Bayard (2007) ${ }^{13}$ mostra, de maneira icônica, como navegar diante das bibliotecas e dos livros que se interpõem em nosso caminho. Num vetor diverso do leitor voraz que Gaston Bachelard formula, Bayard propõe o universo da não leitura. Sua tese é simples: o livro pode ser lido de muitas maneiras embora nunca se possa ter uma leitura definitiva. O que resta de uma leitura será sempre uma não leitura. Os fragmentos e a memória dos livros efetivamente lidos e daquelas não lidos se inserem na vida cotidiana e constituem a dimensão estética da vida. Assim, "entre um livro lido com atenção e um livro que jamais tivemos em mãos e do qual jamais ouvimos falar, múltiplos degraus existem” (BAYARD, 2007, p. 17).

O autor propõe que se pode falar e escrever sobre livros não lidos. Sobretudo porque, conforme seu pensamento, nenhum livro é "totalmente" lido. Em suas formulações, Bayard apresenta uma teoria da leitura, que deslinda ainda em uma espécie de pedagogia da leitura ou, se se quiser, em uma educação pela cultura. Este autor ataca três supostas imposições do universo letrado: primeiro, a obrigação de ler; segundo, a obrigação de ler tudo; terceiro, a necessidade de ter lido um livro para falar dele com um pouco de precisão. Além de denunciar

\footnotetext{
13 Optamos por trabalhar com Bayard (2007) porque sua abordagem da leitura converge com as posições nassarianas, das quais emergem as perspectivas de que a vida supera a literatura e de que a leitura é um jogo simbólico de trocas de prestígio. Sendo assim, as teorias, a academia e a universidade seriam, tal como o é a literatura: um "jeitinho" de cair na vida.
} 
a "hipocrisia geral sobre os livros efetivamente lidos" (p. 15), Bayard apresenta uma maneira de apreciação da cultura em si, para

nos livrarmos da imagem opressora de uma cultura sem lacunas, transmitida e imposta pela família e pelas instituições escolares, imagem com a qual tentamos em vão a vida inteira chegar a coincidir. Pois a verdade destinada aos outros importa menos do que a verdade sobre si, acessível somente a quem se liberta da importuna exigência de parecer culto, exigência que nos tiraniza e nos impede de sermos nós mesmos (BAYARD, 2007, p. 152).

Podemos pensar, a partir desta colocação, em uma cultura que nos concede a oportunidade de visitar seus produtos quando quiser (e puder) para deles extrair algo que nos possibilite a (re)construção de nós mesmos. Bayard nos fala dos "livros que não conhecemos", dos "livros que folheamos", dos "livros de que ouvimos falar" e dos "livros que esquecemos". Introduzindo exemplos e personagens da própria literatura, o autor descortina diferentes maneiras de "não ler" um livro. Assim sendo, apresenta uma concepção singular da leitura:

\begin{abstract}
A leitura é primeiramente a não-leitura, e, mesmo entre os grandes leitores que lhe dedicam sua existência, o gesto de apreensão e abertura de um livro oculta sempre o gesto inverso que é efetuado ao mesmo tempo e que escapa, por causa disto, à atenção: o gesto involuntário de não-apreensão e de fechamento de todos os livros que poderiam, numa organização de mundo diferente, ter sido escolhidos no lugar do feliz eleito (BAYARD, 2007, p. 26).
\end{abstract}

Nesse caso, um livro aberto omite outros tantos não abertos e esse itinerário de leitura acaba movendo a própria cultura. Mais do que questionar a qualidade da leitura, em si, a irônica "não leitura" de Pierre Bayard nos coloca a perspectiva de fundo de que é na vida que a leitura se completa e é para ela que se move. Por ventura, "qualidade de leitura" difere significativamente de "qualidade de conhecimento", como o próprio Nassar nos mostra:

até a virtude em excesso é nociva. Entende? Importa é a qualidade do conhecimento.
Tenho cruzado com gente erudita que é tão perdida quanto uma dona de casa em meio
aos eletrodomésticos. Me dão em geral a impressão, o erudito, de que não sabe
combinar informações, a dona de casa, de que não sabe mexer com os botões.
Pessoalmente, prefiro me adestrar numa postura diante do mundo. A simples
descoberta, por exemplo, de que se pode pensar com a própria cabeça, independente
dos juízes de autoridade, vale por todas as universidades e por todas as bibliotecas
(NASSAR, 1983, p. 104). A menção aos "juízos de autoridade" 14 que Raduan nos propõe sugere que o conceito de "biblioteca" pode ser deslocado para o campo imaterial, extrapolando inclusive os próprios

\footnotetext{
${ }^{14}$ Nas ocasiões em que Raduan se refere a "pensar com a própria cabeça", recusando a realidade dada pelas autoridades de todo tipo, rechaçando o que chama de "ídolos", está fortemente influenciado pelo pensamento do filósofo empirista Francis Bacon, embora a noção nietzscheana "crepúsculo dos ídolos" (NIETZSCHE, 2001),
} 
livros, mediante o fato de que a leitura é um conceito que abrange textos, imagens, situações, contextos, pontos de vista, narrativas etc., multiplicando-se e dando peso à concepção do aspecto formativo da literatura voltado para a vida em si.

Bayard apresenta três tipos de bibliotecas: a biblioteca interior, a biblioteca coletiva e a biblioteca virtual. Essas bibliotecas são metáforas para assinalar janelas e portas para olhares e entradas na cultura, como se verá. O método de Bayard supõe que se possa conhecer comunicações e correspondências nos e entre os livros e os elementos da cultura. Nesse caso, quem transita entre corredores de bibliotecas transita também por catálogos, índices, resumos e títulos de obras, configurando a importante "visão de conjunto" da cultura. Seria a educação pela cultura, então, uma questão de orientação. O que importa é conhecer a situação do livro em relação a outros livros, em relação a outros leitores e em relação à cultura em geral. Certamente que é desejável conhecer profundamente o conteúdo dos livros, mas é igualmente conveniente lançar mão da paródia de Morin à Montaigne: é melhor uma cabeça bem-feita do que uma cabeça bem cheia (MORIN, 2010). Dito de outro modo, é pouco interessante mapear a estrutura de um livro sem que com isso se possa dialogar com outros e com a cultura e também que se possa dialogar com a vida e com a circunscrição que a leitura conduz diante do tempo. Nesse caso, a biblioteca coletiva se mostra da seguinte maneira: "a maior parte das trocas sobre um livro não diz respeito a ele, apesar das aparências, mas a um conjunto muito mais amplo, que é o de todos os livros determinantes sobre os quais repousa uma certa cultura em um momento dado" (BAYARD, 2007, p. 32).

A biblioteca coletiva permite-nos transitar entre os livros que não conhecemos com relativa tranquilidade. Não se trata de tomar um atalho ou de insinuar uma possibilidade de conhecimento sub-reptício, mas buscar a humildade da razão, a humildade na nossa relação com os livros, o que significa ter com eles uma ligação de gentileza. Como gerente das escolhas, o leitor arrefece a febre dos livros não lidos, pois, também pode falar sobre eles.

Sem pretensão de totalidade, o escritor realiza semelhante ato de escolha, convergindo uma pesquisa rigorosa enquanto emprega metáforas que convocam geografias e horizontes. Essa radical passionalidade é medida pelos gestos de seleção. A seleção das palavras e dos contextos atende à memória afetiva, ao humor, às sensações, ao espirito do tempo, ao que lhe toca o coração. Assim se instala a cordialidade entre uma ciência positiva e seus fundamentos

dentre outras noções filosóficas, contemplem uma perspectiva análoga. Hugo Marcelo Abati, em sua dissertação de mestrado, interpreta o uso dos conceitos baconianos na obra Lavoura arcaica: "André vai desnudando aquilo que Francis Bacon chama de ídolos, representações falsas ou preconceitos enraizados no ser humano que dificultam o conhecimento da realidade. Haveria, segundo o filósofo, quatro tipos de ídolos: os da tribo, da caverna, do foro e do teatro" (ABATI, 1999, p. 163). 
movediços, posto que a escrita comporta esse estado passional. Nesse caso, a filosofia, a ciência ou a educação podem também serem gestos de devaneio poético.

Além disso, podemos falar dos livros que folheamos: uma vez que se saiba transitar pela biblioteca coletiva pode-se também circular pelos livros percorrendo a obra. Pode-se optar por um percurso linear: "o leitor começa o texto pelo princípio, depois começa a saltar linhas ou páginas e se dirige, alcançando-o ou não, para o final" (BAYARD, 2007, p. 51). Ou pode-se optar por um percurso circular: "o leitor não opta por uma leitura ordenada, mas passeia pela obra, algumas vezes começando pelo final” (p. 51). Queremos qualificar uma leitura interrompida, já que o leitor contemporâneo "lêe" series, filmes, livros, bulas de remédio, enquanto envia mensagens de texto e interage com tantos outros em redes sociais. Isso sem falar das plataformas físicas de leituras: e-books, livros grandes, pequenos, grifados com canetas ou lápis, com orelhas, amarelados, revendidos, emprestados da biblioteca etc. A aventura do livro e da literatura na contemporaneidade é diversa e irrompe no cotidiano das pessoas das maneiras mais criativas. Questionando sobre como qualificar este "não leitor", Bayard nos incita a refletir:

\begin{abstract}
em qual categoria classificar os que passaram um certo tempo com um livro, até mesmo horas, sem lê-lo integralmente? Pode-se dizer, se tiverem que falar de um livro, que estarão falando de um livro que não leram? [...] e pode-se perguntar qual é o melhor leitor, aquele que lê em profundidade uma obra sem poder situá-la ou aquele que não entra em nenhuma, mas circula em todas (BAYARD, 2007, p. 51).
\end{abstract}

Casualmente, o leitor pedagogicamente "desejável" oscila entre as duas figuras: "leitor de uma só obra" e "leitor de todas as obras". Ademais, circular pelas obras é um currículo possível para os itinerários de formação, construção ampla e aberta de educação pela cultura, conforme formulada por Rogério de Almeida:

Os itinerários de formação atestam, em primeiro lugar, que a educação não se dá unicamente na escola, mas também fora de seus muros e portões, longe das carteiras e da lousa. Em segundo lugar, não se dá de maneira única, por meio da definição prévia de conteúdos e métodos, mas de forma plural, aberta, mobilizando toda a atenção e energia e modificando a compreensão que se tem de si e do mundo. Em terceiro lugar, os itinerários, como o próprio nome sugere, pressupõe a educação como uma relação dinâmica, processual, feita de avanços e retrocessos, de dúvidas e retomadas, de conhecimentos que se revisitam. Finalmente, os itinerários de formação são percorridos ao longo de toda vida, pois é vivendo que nos educamos, que fazemos escolhas, que temos de afrontar os desafios que cada momento nos impõe (FERREIRA-SANTOS; ALMEIDA, 2011, p. 144-145).

Assim sendo, o percurso formativo do leitor se materializa dentro e fora das instituições de ensino (muitas vezes mais fora do que dentro), evocando fontes diversas e, por vezes, 
conflitantes de conhecimento, pautando-se na errância processual daquele que aprende. Desse modo, a leitura interrompida é um itinerário de formação que se orienta pela relação com os livros marcada pela confusão e pela interrupção em digressão, evasão, dispersão, descontrole, ansiedade, desorientação, desentendimento, descontrole, raiva, fome, sede, dor, medo, esperança, desespero, em um conjunto de fatores tão imprevisíveis quanto específicos concorrendo todos eles ao mesmo tempo no singular instante de leitura.

No quadrante de Pierre Bayard é possível tratar dos livros de que ouvimos falar, a partir de uma dupla orientação: "cultura é a capacidade de situar os livros dentro da biblioteca coletiva e de se situar no interior de cada livro [...] faz com que a ideia de leitura termine se desvinculando da ideia de livro material para se remeter à de encontro, que pode perfeitamente operar com um objeto imaterial" (BAYARD, 2007, p. 53). Ora, não seria o encontro o cerne mesmo da pedagogia? Não seria neste irreproduzível encontro (erótico) com o mundo e com o outro que se substancia o conhecimento? A pedagogia do livro de Bayard nos fornece um mapa para que possamos trafegar diante de uma cultura complexa como a nossa.

Aquém e além dos livros reais estão os livros encobridores. São esses que correspondem a biblioteca coletiva, pois são, com efeito, as imagens criadas a respeito dos livros: "a partir do tempo da leitura e mesmo sem esperá-lo, nós começamos, sozinhos e depois com os outros, a nos falar dos livros, e esses discursos e opiniões mais tarde se tornarão nossa referência, relegando para longe de nós os livros reais, tornados hipotéticos para sempre” (p. 67). O movimento de distanciamento e aproximação do leitor diante de um texto possibilita também o engendramento subjetivo, como compreendido por Paul Ricoeur (1988):

assim como o mundo do texto só é real na medida em que é fictício, da mesma forma devemos dizer que a subjetividade do leitor só advém a ela mesma na medida em que é colocada em suspenso, irrealizada, potencializada, da mesma forma que o mundo é manifestado pelo texto. Em outras palavras, se a ficção é uma dimensão fundamental da referência do texto, não possui menos uma dimensão fundamental da subjetividade do leitor. Só me encontro, como leitor, perdendo-me. A leitura me introduz nas variações imaginativas do ego. A metamorfose do mundo, segundo o jogo, também é a metamorfose lúdica do ego (RICOEUR, 1988, p. 59).

As dinâmicas formativas que se vão delineando com os livros encobridores na biblioteca coletiva serão consumadas quando desejamos falar dos livros que esquecemos. Adentrando na dimensão do tempo - na sua relação com a leitura, o sobrevoo pelos livros e pela cultura vai se tornando efetivamente um percurso, um itinerário de formação, diante do qual o esquecimento é fundamental: "a leitura não é somente conhecimento de um texto ou aquisição de um saber. Ela está também, e a partir do momento em que se inicia, engajada em 
um irreprimível movimento de esquecimento" (BAYARD, 2007, p. 69). A desleitura vai formando a biblioteca interior, "parte subjetiva da biblioteca coletiva, comportando os livros marcantes de cada assunto" (p. 95). Ou seja, há uma biblioteca coletiva, depositária de obras em suas transações comuns, marcada pelas imagens dos livros, os livros encobridores. Nesse caso, o sujeito, diante desses livros encobridores e dessa biblioteca coletiva, formula sua biblioteca interior, maneira pela qual acessa a biblioteca coletiva.

Reordenando as circunstâncias de Bayard, podemos falar de livros que não conhecemos porque é possível tratá-los a partir de sua situação diante da biblioteca coletiva. Podemos falar de livros que folheamos se pudermos transitar pelo desenho discursivo destas obras. Podemos falar de livros de que ouvimos falar pois é a imagem do livro o que nos anima. Finalmente, podemos falar dos livros que esquecemos pois permanece a aura da desleitura realizada. Esses movimentos são possíveis à medida que a cada novo livro que se nos interpõe mobilizamos o livro interior:

conjunto de representações míticas, coletivas ou individuais, que se interpõem entre o leitor e todo novo escrito e que interferem em sua leitura sem que ele saiba. Muito inconsciente, esse livro imaginário exerce a função de filtro e determina a recepção de novos textos, decidindo quais dos seus elementos serão retidos e como serão interpretados (BAYARD, 2007, p. 105).

Nesse caso, é a partir dos livros que efetivamente lemos que recebemos novos livros, que iremos efetivamente ler ou que, ao contrário, simplesmente situaremos no conjunto da biblioteca coletiva. Nomeadamente, a leitura interrompida será um movimento de preparação futura sem com isso perder o prazer-leitor do presente. Ou melhor, se tenho no horizonte um conjunto de obras que gostaria de ler, cada vez que uma delas é lida vai gerando um acúmulo que, por sua vez, receberá obras subsequentes. Como o projeto de leitura é longo e marcado por constantes interrupções, trabalhamos alternadamente com o discurso sobre os livros lidos e sobre os livros não lidos: "a existência do livro interior é, junto com a desleitura, o que torna o espaço de discussão sobre os livros descontínuo e heterogêneo" (p. 108).

Elementos de sedução, os livros que amamos, que criam e recriam nosso mundo são a possibilidade de comunicação com o universo do outro. Isto se, sobretudo, soubermos usar a fórmula em seu sentido contrário: todo orador ou escritor conversa com um público, com um auditório, no limite, conversa com o toda a Humanidade (PERELMAN, C.; OLBRECHTSTYTECA, L.; 1996). Daí que orador ou escritor - se se quiser professor e estudante - participam de uma conversa, do burburinho que constitui a cultura através de uma biblioteca virtual: “espaço, oral ou escrito, de discussão de livros com os outros. Ela é uma parte em movimento 
da biblioteca coletiva de cada cultura e se situa no ponto de encontro das bibliotecas interiores de cada participante da discussão" (BAYARD, 2007, p. 148). Quando o escritor contribui para a formação da biblioteca coletiva, decerto, se dinamiza na biblioteca virtual quando citado. Raduan nos mostra seu embasbacamento diante da infinidade de livros: "era eu entrar numa livraria para achar que não teria nada a acrescentar à montanha de coisas que já tinham sido ditas" (NASSAR, 1997b, p. 10). A consciência de menoridade que aparece em Raduan nos remete, ao contrário, a arrogância de tratamento da literatura nos meios escolares:

\begin{abstract}
espaço de violência onde, em meio à fantasia de que existiriam leituras integrais, tudo é feito para saber se os alunos que o habitam efetivamente leram os livros de que falam ou sobre os quais são interrogados. Com a intenção ilusória, já que a leitura não obedece à lógica do verdadeiro e do falso, de dissipar a ambiguidade e de avaliar com certeza se eles dizem ou não a verdade (BAYARD, 2007, p. 151).
\end{abstract}

São conhecidos os exemplos do estudante de diferentes níveis de ensino que aprende a dizer o que o professor quer ouvir ou do estudante que aprende tanto na elaboração de uma cola que já não mais precisa dela no momento da prova. Fica patente a inadequação de tratamento da leitura nas instituições de ensino.

O último tipo de livro que Bayard nos oferece é o livro-fantasma, "objeto elusivo e movente que fazemos surgir, oralmente ou por escrito, quando falamos de um livro. Ele está no ponto de encontro dos diferentes livros encobridores que os leitores constroem a partir de seus livros interiores" (BAYARD, 2007, p. 181). Sintetizando a proposta de Bayard, a leitura de um livro torna-se desleitura com o passar do tempo, construindo livros encobridores situados na biblioteca coletiva. A partir do livro interior e da biblioteca interior (elementos pessoais) que se pode acessar a biblioteca virtual das conversas e, finalmente, falar dos livros (não) lidos como livros-fantasma.

Isto posto, transitar pela cultura e pelos livros significa mobilizar a sensibilidade de criador que cada pessoa tem, "escutar as virtualidades da obra, analisar o novo contexto em que ela acaba de se inscrever, prestar atenção nos outros e em suas reações, ou ainda conduzir uma narração que absorva" (p. 205). Se o que sobressai deste percurso é a possibilidade de inventar o livro de que se fala estamos falando, por conseguinte, da invenção de si próprio. O livro responde, à sua maneira, à maneira do leitor e da cultura que o recebe, a pergunta fundamental, o que é o homem? Nesse caso, as imagens de homem projetadas em determinado livro dialogam com a projeção de homem que se insinua em cada leitor, ocasionalmente partilhada com outros leitores, conquanto participem da mesma condição humana. Assim sendo, das leituras interrompidas se possam fazer escrileituras do sensual, como propõe sensivelmente Márcio 
Porciúncula Ferreira (2008), tratando da escrita educacional sob a influência de alguns autores, dentre os quais, Raduan Nassar. A escrileitura será senão gesto visceral, irreproduzível e erótico, no concurso obtuso e sinuoso da aventura de qualquer leitor, reescrevendo para si e em si aquilo que o preenche como circulação sanguínea.

\subsection{POR UMA HERMENÊUTICA SIMBÓLICA}

A peculiar forma de interpretação que adotamos neste trabalho, a hermenêutica simbólica, é solidária de um conjunto de estudos transdisciplinares que orbitam em torno dos estudos do imaginário. Segundo Daniele Rocha Pitta (2005), este campo tem início com o estudo "sistemático e interdisciplinar" (p. 13) dos símbolos realizados pelo filósofo francês Gaston Bachelard (1884-1962), em que pese a fundação da Société de Symbolisme em Genebra, datada de 1950, com o consequente início, em 1962, da publicação Cahiers Internationaux de Symbolisme. Ao estudar a epistemologia, Bachelard acaba por encontrar nos símbolos a possibilidade de um novo espírito científico. Gilbert Durand (1921-2012), partícipe da La Résistance, discípulo de Bachelard e interessado pela psicologia das profundezas de Carl Gustav Jung, funda em 1967 o Centre de Recherches sur l'Imaginaire, em Chambéry (França), que passa a publicar a revista Circé.

Naquele contexto surge um particular campo de pesquisas solidário das transformações da virada do século XIX para o XX. Segundo Durand (2012), um conjunto de fatores possibilitou a afirmação do imaginário como área de estudos, dentre os quais destacamos o romantismo alemão e a psicanálise freudiana, que reabilitavam o sonho e os mitos da iconoclastia ocidental. Dentre os autores que se dedicaram e se dedicam a estes estudos citamos Jean Baudrillard, Michel Maffesoli, Edgar Morin, Mircea Eliade, Henry Corbin e Paul Ricoeur. Este último sagrou-se entre os mestres da suspeita com seus estudos sobre Marx, Nietzsche e Freud. Além disso, a partir de suas críticas a Gadamer e Husserl, estabeleceu uma abordagem instauradora dos símbolos em sua hermenêutica.

Os espaços de estudos do imaginário se espalharam por vários lugares do mundo e continuam a produzir pesquisas, como é o caso do Instituto de Estudos de Literatura e Tradição em Lisboa. No Brasil há uma multiplicidade de áreas em que a abordagem do imaginário é demandada, como Linguística (NUPLIN da PUC-SP), História (Grupo de Estudos do Imaginário da UFPB), Sociologia (UFPB), Antropologia e Comunicação (Núcleo Interdisciplinar de Pesquisas sobre o Imaginário da UFPE) e Educação (LIRES da UGF-RJ e o Centro de Estudos sobre Imaginário, Cultura e Educação da USP). 
Neste tópico apresentaremos a mudança paradigmática que constituí epistemologicamente o campo da antropologia do imaginário, de onde se abre a possibilidade para uma hermenêutica à procura de repetições e recorrências simbólicas nas produções culturais, como é o caso dos textos literários.

\subsubsection{Teoria e método no horizonte de uma mudança paradigmática}

A dúvida e a incerteza, elementos fundamentais do espírito científico, para Edgar Morin, reintroduzem o sujeito na construção do conhecimento. Segundo este autor, "a ciência, na concepção 'clássica' [...] elimina do seu meio toda a competência ética e baseia seu postulado de objetividade na eliminação do sujeito do conhecimento científico" (MORIN, 2002, p. 117). Nessa direção, sua abordagem complexa nos alerta para a imprevisibilidade: "o ato de um indivíduo ou de um grupo entra num complexo de inter-retroações que o fazem derivar, desviar e, por vezes, inverter seu sentido" (p. 118). Por um lado, o pensamento hegemônico isola sujeito e objeto, por outro lado, a filosofia e outras ciências desenvolveram relações de causa e efeito na busca pelas causas primordiais de onde derivaria um sistema de funcionamento dos fenômenos naturais e humanos. Veremos como o sujeito e o objeto de conhecimento são indissociáveis e que, também, causa e efeito formam um binômio recursivo.

A teoria da complexidade de Morin possibilita conceber uma dialogia constante entre sujeito e objeto, entre causa e efeito, entre teoria e método: “o método é a práxis fenomenal, subjetiva, concreta, que precisa da geratividade paradigmática/teórica, mas que, por sua vez, regenera esta geratividade. Assim, a teoria não é o fim do conhecimento, mas um meio-fim inscrito em permanente recorrência" (MORIN, 2002, p. 335-336). A produção de conhecimento se dá contextualmente, na história, em uma cultura, em uma sociedade, em um momento político, vinculada a especificidades éticas. Desse modo, Morin propõe que situemos o sujeito no centro da complexidade: o conhecimento reinventa o sujeito que reinventa o saber, a sociedade e a cultura, como partícipe do grupo humano. Assim sendo, assinalam-se os papéis da teoria e do método na construção do conhecimento:

uma teoria não é o conhecimento; ela permite o conhecimento. Uma teoria não é uma chegada; é a possibilidade de uma partida. Uma teoria não é uma solução; é a possibilidade de tratar um problema. Em outras palavras, uma teoria só realiza seu papel cognitivo, só ganha vida com o pleno emprego da atividade mental do sujeito. É essa intervenção do sujeito que dá ao termo método seu papel indispensável (MORIN, 2002, p. 335). 
O método como caminho, reintegrando, a um só tempo, a corporeidade e a imagem como formas de conhecimento. O corpo, a imagem e a sensibilidade, no contexto do racionalismo e do positivismo, foram se marginalizando como dimensões de engano, mentira, erro e fantasia. Retomar o sensível e o complexo, em tal contexto, significa recobrar o símbolo e o mito como formas de saber:

\begin{abstract}
se instalar plenamente nessa realidade antropológica bem mais vital, bem mais importante para o destino e, principalmente, para a felicidade do homem que a verdade morta tem por objetivo. Pois é entre as verdades objetivas desmistificadoras e o insaciável querer ser, constitutivo do homem, que se instaura a liberdade poética, a liberdade "remitificante". Mais do que nunca, sentimos que uma ciência sem consciência, ou seja, sem afirmação mítica de uma Esperança, marcaria o declínio definitivo de nossas civilizações (DURAND, 1988, p. 111).
\end{abstract}

Edgar Morin e Gilbert Durand alertam para a necessidade de equilibração entre a razão e a sensibilidade na constituição do conhecimento. A primazia contemporânea das tecnologias na construção do conhecimento reitera o fazer científico como aplicação de um método sem interferências do sujeito, tendo como ideal a construção de um suposto saber neutro. A revelia da neutralidade e da objetivação do conhecimento pelas ciências hegemônicas, apontamos a mudança paradigmática de um novo espírito científico: “insistiremos [...] no valor dilemático das novas doutrinas como a geometria não-euclidiana, a medida não-arquimediana, a mecânica não-newtoniana com Einstein, a física não-maxwelliana com Bohr, a aritmética de operações não-comutativas que poderíamos designar como não-pitagórica” (BACHELARD, 1984, p. 94). Bachelard aponta que, além da dicotomia sujeito-objeto, a observação e a descrição dos fenômenos carregam a marca das teorias e dos métodos escolhidos pelo sujeito. Nessa direção, se faz necessário admitirmos a multiplicidade de entendimentos que os fenômenos comportam: "considerando que o objeto se apresenta como um complexo de relações, é preciso apreendê-lo por métodos múltiplos" (p. 96).

A segregação entre a razão e a imagem, para Bachelard, decorre de um pensamento dualista: "depois de ter formado, nos primeiros esforços do espírito científico, uma razão à imagem do mundo, a atividade espiritual da ciência moderna empenha-se em construir um mundo à imagem da razão" (p. 96). A validade das considerações de Bachelard confirma a potência criativa do pensamento e o papel dos sentidos para o conhecimento, rompendo com a hegemonia do cogito:

ao invés dessa comunhão com uma realidade global à qual o cientista voltaria com alegria, como a uma filosofia original, não conviria, para compreender a evolução intelectual, prestar atenção ao pensamento ansioso, ao pensamento em busca de 
objeto, ao pensamento que procura ocasiões dialéticas de sair de si mesmo, de romper seus próprios quadros, numa palavra, ao pensamento em via de objetivação? Não se pode deixar de concluir que tal pensamento é criador (BACHELARD, 1984, p. 178).

O conjunto de transformações que Bachelard recupera nas ciências naturais posteriormente o levará a considerar a imaginação como propulsão de conhecimento nas suas cinco obras dedicadas aos quatro elementos (fogo, água, terra e ar). Nessa direção, há um conjunto de autores que se orientam conforme uma mudança paradigmática ${ }^{15}$ na qual a hermenêutica simbólica ${ }^{16}$ se inspira como opção metodológica instauradora para a pesquisa envolvendo produtos culturais.

Esta mudança paradigmática a que nos referimos sugere alternar a razão técnica por uma razão aberta. Compõe-se na coincidentia oppositorum (convivência dos opostos) e no tertium datum (terceiro incluído) como propõe a razão complexa (Edgar Morin) e a razão sensível (Michel Maffesoli), reconduzindo sinergicamente sujeito e objeto e reabilitando a corporeidade no sujeito do conhecimento. Deste modo, incidimos em uma hermenêutica simbólica (Paul Ricoeur e Gilbert Durand) capaz de reinvestir os símbolos, as imagens e os mitos em sua potência criadora, formativa e promotora do conhecimento. Radicada em uma antropologia simbólica, a condição humana se pode avistar, dinâmica e multidirecional, como resposta a angústia existencial do Homem, eufemizada nas traduções simbólicas que compõem o imaginário (MORIN, 1973). Animados por uma fenomenologia compreensiva (MAFFESOLI, 1998), desejamos apresentar e criar o objeto observado, apalpado, digerido por nós, a literatura nassariana. As construções que aqui se desenham se orientam, portanto, a partir de uma perspectiva transdisciplinar:

desde a "crise da física" até à "revolução biológica", sobretudo S. Lupasco, E. Morin e G. Durand vêm identificando uma polaridade paradigmática: o "paradigma clássico" (que Morin chama de "paradigma da simplificação/redução/disjunção/exclusão", que remonta ao "racionalismo" e, com a solidariedade tecno-científica, à "racionalidade técnica" e, portanto, à "razão técnica" e às "praxeologias"), por um lado; por outro lado, com as referidas crises epistemológicas, a nova proposta paradigmática - "shift paradigma” e re-paradigmação -: paradigma holista (Koestler), paradigma do

\footnotetext{
${ }^{15}$ Deve-se a Thomas Kuhn (2007) o termo "paradigma", que se refere à construção social da ciência. Segundo este autor, a ciência baseia-se em paradigmas originados de consensos entre especialistas de áreas específicas. Em determinado momento as anomalias passam a crescer e deixar muitas questões em aberto conduzindo para uma "crise". A resolução desta crise se dá quando um "novo paradigma" proposto é amplamente aceito pela mesma comunidade científica de outrora. Este é o movimento referido por uma "mudança paradigmática".

${ }^{16}$ A hermenêutica simbólica ou mitohermenêutica caracteriza-se como um "trabalho filosófico de interpretação simbólica, de cunho antropológico, que pretende compreender as obras da cultura e das artes a partir dos vestígios (vestigium - traços míticos e arquetipais - captados através do arranjo narrativo de suas imagens e símbolos na busca desta filosofia latinomediterrânea, produtora e produto da cultura latina. Relembrando a sugestão de Paul Ricoeur, aliamos ao estilo mitohermenêutico o olhar do geógrafo, o espírito do viajante e a criação do romancista" (FERREIRA-SANTOS; ALMEIDA, 2012, p. 119).
} 
antagonismo contraditorial (Lupasco, Durand), paradigma holográfico (neuropsicofisiologia de Pribram), em suma, desde o Colóquio de Córdoba "paradigma holonômico" ou "paradigma da complexidade" em Morin, a par de uma proposta de "razão aberta" (Gonseth) (CARVALHO, 1990, p. 21, grifo nosso).

Situamos, portanto, a mudança paradigmática no contexto da reanimação do símbolo como possibilidade de conhecimento, condição que tem consequências filosóficas, pedagógicas e culturais. Esta mudança paradigmática de caris holonômico não se investe como novidade redentora, mas recuperando formulações, caminhos e hermenêuticas que se caracterizam por uma razão aberta e uma interpretação instauradora. O "paradigma holonômico", entendido por Marcos Ferreira Santos (1998) como gradiente holonômico, preservando a multiplicidade do holos e incorporando o sentido de gradação, "tem como fundamento uma ontologia pluralista, uma epistemologia interativa/holonômica, uma lógica polivalente (contraditorial), uma causalidade probabilística (em redes), uma metodologia fundada na fenomenologia compreensiva, uma análise estrutural e uma linguagem simbólica" (FERREIRA-SANTOS; ALMEIDA, 2012, p. 126).

A coincidentia oppositorum e o tertium datum ressignificam a lógica descontruindo os princípios da não contradição e do terceiro excluído da lógica formal aristotélica. Como desenvolvido na Metafísica de Aristóteles (2012), se "A é A", na mesma relação e ao mesmo tempo, "A" não pode ser "não A". Dito de outro modo, o que é, é, e o que não é, não é, algo não pode ser e não ser ao mesmo tempo: "todas as coisas têm que ser ou afirmadas ou negadas, e é impossível simultaneamente ser e não ser, e todas as demais proposições deste caráter" (ARISTÓTELES, 2012, p. 87). Nesse caso, Sócrates não pode ser e não ser mortal ao mesmo tempo. Sócrates é mortal ou Sócrates não é mortal são premissas mutuamente excludentes. Seguindo na lógica binária, o "princípio do terceiro excluído" indica que algo só pode ser A ou B, verdadeiro ou falso, não pode ser X, V, H, Y, C, F, não há uma terceira possibilidade. Ou a premissa é verdadeira ou ela é falsa: Sócrates é mortal ou não é mortal.

Dito isso, a abordagem holonômica apontará para o convívio dos contrários, possibilitando a conversão e a convivência de compreensões antagônicas para um entendimento dialógico dos fenômenos. Nesse caso, não se trata de uma síntese dialética em termos hegelianos ou marxistas, mas como complementariedade e convivência de antagonismos que mantém entre si suas tensões e suas características peculiares. Além disso, o terceiro incluído reinterpreta o conhecimento superando os dualismos mente/corpo, sagrado/profano, sujeito/objeto, tese/antítese. A inclusão deste terceiro é o que nos permite pensar em uma razão sensível, mobilizando na construção do saber tanto as dimensões sensível e estética quanto as 
dimensões racional e formal, de modo que se possa incorporar, integrar e retroalimentar o conhecimento recursivamente.

Tanto a razão complexa de Edgar Morin quanto a razão sensível de Michel Maffesoli convergem para a crítica do racionalismo positivista. Maffesoli (1998) critica o moralismo do dever ser, a partir do qual se organiza o imperativo categórico kantiano, a lógica formal aristotélica e o intelectualismo cartesiano. Segundo Michel Maffesoli, a ciência do dever, problematizada nas três metamorfoses de Nietzsche (2011), pode ser superada por um conhecimento erótico, uma sensibilidade generosa, um saber dionisíaco: "estabelecer a topografia da incerteza e do imprevisível, da desordem e da efervescência, do trágico e do não racional" (MAFFESOLI, 1998, p. 13). O camelo técnico-racional se pode transmutar no leão do conhecimento imiscuído em desejo ou mesmo na criança do trágico (NIETZSCHE, 2011). Para Maffesoli o conhecimento pode partir da vida comum, do cotidiano, da experiência sensível e da vivência em detrimento de uma razão instrumental: "não se pode assimilar a humanidade, também movida pela paixão e pela não-razão, ao objeto morto das ciências naturais" (p. 17).

Reconhecendo a ambivalência do objeto e das situações da vida, Maffesoli propõe a substituição da representação pela apresentação dos objetos. Uma fenomenologia compreensiva ${ }^{17}$ que se preocupa mais com o anúncio do que com a denúncia, mais com a beleza do que com a crítica, construindo, deste modo, um alegre saber e incorporando a contemplação do mundo e o estilo como aportes intelectuais que aproximam a arte do conhecimento e da vida. Nesse caso, o autor comenta as relações entre racionalismo e imaginário da seguinte maneira:

O racionalismo revelador de mensagens vai direto ao alvo, segue essa via recta cuja eficácia é conhecida. Totalmente outro é o caminhar incerto do imaginário. Isso culmina num saber raro; um saber que, ao mesmo tempo, revela e oculta a própria coisa descrita por ele; um saber que encerra, para os espíritos finos, verdades múltiplas sob os arabescos das metáforas; um saber que deixa a cada um o cuidado de desvelar, isto é, de compreender por si mesmo e para si mesmo o que convém descobrir; um saber, de certa forma, iniciático (MAFFESOLI, 1998, p. 21).

\footnotetext{
17 A fenomenologia compreensiva contempla perspectivas e práticas das "correntes sócio-antropológicas de estudos sobre o cotidiano e o imaginário, estribados na hermenêutica simbólica" (FERREIRA-SANTOS; ALMEIDA, 2012, p. 102). Este campo, "além de se pautar pelos princípios comuns da fenomenologia (desde Husserl e Merleau-Ponty) no exercício difícil de um olhar 'como se fosse a primeira vez', já sem a ingenuidade do desconhecimento, pautado pela epoché (suspensão dos pré-juízos, pré-julgamentos, pré-conceitos), descrição densa do fenômeno (aquilo que aparece) e busca dos sentidos (sinngenesis), se acrescenta a essa concepção a natureza compreensiva do ato investigativo" (p. 102, grifo nosso). Ressalte-se a primazia de tal perspectiva nos estudos sociais, aqui a deslocamos para a investigação cultural e poética, sugestivamente manifesta nos produtos culturais, diante dos quais empenhamos uma hermenêutica simbólica.
} 
Para Maffesoli, “a paixão, o sentimento, a emoção e o afeto (re)exercem um papel privilegiado" (p. 22) na construção do conhecimento. O pensamento reconciliado com a vida, equilibrado no senso comum, valorizando a metáfora e o cotidiano, possibilita um vitalismo, um saber cúmplice da própria vida. O racionalismo tecnocrático, o utilitarismo programado, separa o conhecimento em seu ímpeto analítico, tornando incomunicáveis as noções de bem e mal. Este vitalismo pode ser notado, inclusive, nas próprias declarações de Raduan Nassar: "as pessoas de São Paulo são muito sofisticadas. Entendem mesmo é de informática e isso não é uma ciência de vida" (NASSAR, 1998, p. 5, grifo nosso). O pensamento audacioso que Maffesoli nos apresenta converge com o pluriculturalismo contemporâneo, evitando a segregação:

\footnotetext{
a hegemonia da cultura ocidental já teve, também ela, o seu tempo. A época é de pluriculturalismo, e todas as filosofias, religiões, maneiras de ser e modos de pensamento que consideramos arcaicos, retrógrados, ou simplesmente anacrônicos, estão agora solidamente estabelecidos no próprio seio de nossas sociedades (MAFFESOLI, 1998, p. 37).
}

Ainda em Maffesoli, temos a crítica do conhecimento abstrato que, à maneira da análise, recorta, distingue e recompõe, tendendo ao dogmatismo. O autor localiza sua recuperação do sensível, solidária do romantismo alemão, da poesia de Baudelaire e a par do pós-moderno, remetendo-o como operação agregadora e diversa para a qual concorre um saber intuitivo. Nesses termos, o pensamento de Maffesoli, solidário da ruptura epistemológica ora admitida, se orienta por uma "fenomenologia compreensiva" que incorpora metodologicamente a descrição, a intuição e a metáfora.

A descrição é descrição poética, imbuída de um estilo que flerta com o lúdico, estabelecendo um pensamento acariciante, um método erótico, à guisa de "mostração" dos fenômenos vinculados a dimensão estética da vida: "a violência prometéica, da qual o conceito é instrumento privilegiado, cede lugar a uma postura dionisíaca que emprega a analogia, a metáfora e outros procedimentos 'acariciantes', que não pretende reduzir o real, indicar-lhe a direção certa mas que se contenta em ressaltá-lo, epifanizá-lo" (p. 122).

A intuição, investida na perspectiva nietzscheana do sim, flui como criança remetendo a uma "ética da estética, isto é, para um etos constituído a partir de emoções partilhadas em comum” (MAFFESOLI, 1998, p. 137, grifo nosso). A intuição navega como imaginação poética, marcada por afetos e por experiências. É proposta a partir de baixo, indutivamente. Conduz para um pensamento holístico, holonômico. Assim sendo, o recurso à metáfora compromete-se a apresentar o que é e não o que deve ser, mostrar as imagens do mundo e da 
obra que aí já estão. O uso da metáfora recria o fenômeno, conduzindo com anima uma epifania que é a expressão do sujeito através do objeto, através da obra de literatura, em nosso caso. Portanto, a fenomenologia compreensiva é solidária do vitalismo:

O conhecimento fenomenológico é prospectivo naquilo que, para além das análises causais ou estatísticas, põe a ênfase sobre um vitalismo que não se orienta para um objetivo preciso, que não se inscreve num linearismo mecanicista, que não possui um sentido unívoco e seguro, mas, antes, que encontra suas forças em si mesmo e, por vezes, cresce de modo bem desordenado, um pouco por todo lado (MAFFESOLI, 1998, p. 128, grifo nosso).

Em outra direção, a segregação entre o real e o irreal é também a divisão entre imaginação formal e imaginação material, como aponta Bachelard (1989). A imaginação formal é própria do pensamento abstrato, geométrico, que constrói o conceito e o virtualiza. Já a imaginação material se realiza em corporeidade ${ }^{18}$ como compreensão epifânica. Tanto Bachelard (2009) quanto Maffesoli (1998) enfatizam a anima, e não o animus, como impulso no desenho deste saber poético elogiado e pretendido na descrição de nosso objeto de pesquisa. A feminização da busca se inscreve no registro de uma intimidade, flertando com o telúrico, o líquido e o viscoso da obra literária de Raduan Nassar. Nessa direção, as rupturas epistemológicas até aqui traçadas abrem caminho para o símbolo e para a sensibilidade na construção do conhecimento, movimento que acreditamos possível por meio de uma deseducação.

\subsubsection{Fundamentos para uma antropologia do imaginário}

A imaginação, em materialidade ou em abstração, é o operador das imagens. É a imaginação que busca na relação corpórea com o mundo a expressão de símbolos e imagens captados do imaginário. A pletora de significados que se desenrola ao retomar a imagem e o símbolo como formas de conhecimento autêntico está agenciada em uma antropologia simbólica: "a dimensão simbólica constitutiva da ação humana pode ser verbalizada no discurso, cristalizada no mito, no rito, no dogma ou incorporada aos objetos, aos gestos, à

\footnotetext{
${ }^{18}$ A noção de corporeidade rompe com o esquematismo dualista de Descartes: "embora talvez eu tenha um corpo ao qual estou muito estreitamente conjugado, todavia, já que, de um lado, tenho uma ideia clara e distinta de mim mesmo, na medida em que sou apenas uma coisa pensante e inextensa, e que, de outro, tenho uma ideia distinta do corpo, na medida em que é apenas uma coisa extensa e que não pensa, é certo que este eu, isto é, minha alma, pela qual sou o que sou, é inteira e verdadeiramente distinta de meu corpo e que ela pode ser ou existir sem ele" (DESCARTES, 2010, p. 193, grifo nosso). A concepção de corporeidade implica, portanto, ser um corpo pensante. Dito de outro modo, o corpo pensa e o pensamento é o corpo. Não há cisão, porém, há uma unidade entre mente e corpo.
} 
postura corporal, e está sempre presente em qualquer prática social” (DURHAM, 2004, p. 259, grifo nosso). Buscando preservar e, ao mesmo tempo, fazer ver a potência do símbolo, Gilbert Durand sugere uma antropologia do imaginário ${ }^{19}$ :

\begin{abstract}
Parece que para estudar in concreto o simbolismo imaginário será preciso enveredar resolutamente pela via da antropologia, dando a esta palavra o seu sentido pleno atual - ou seja: conjunto das ciências que estudam a espécie homo sapiens - sem se pôr limitações a priori e sem optar por uma ontologia psicológica que não passa de espiritualismo camuflado, ou uma ontologia culturalista que, geralmente, não é mais que uma máscara da atitude sociologista, uma e outra destas atitudes revolvendo-se em última análise num intelectualismo semiológico (DURAND, 2012, p. 40, grifo nosso).
\end{abstract}

A preocupação de Gilbert Durand foi diferenciar abordagens instauradoras do símbolo que invistam em seu potencial de sentido e não em seu isolamento como signo, caro à semiologia. Esta perspectiva reorienta e aprofunda a noção de cultura entendida no âmbito simbólico como "universo da criação, da transmissão, da apropriação e da interpretação dos bens simbólicos e das relações que se estabelecem” (FERREIRA-SANTOS; ALMEIDA, 2012, p. 14).

A cultura surge sob os auspícios do tempo, diante da consciência da finitude e da inevitabilidade da morte, conforme o pensamento de Edgar Morin (1973). Partindo da ruptura epistemológica, Morin procura delinear fronteiras entre humano e animal à busca de uma suposta natureza humana. Nesse caminho o autor encontra indícios da construção cultural do sapiens dialogando com o demens ${ }^{20}$, fator fundamental para a compreensão do homem como produtor de símbolos. Segundo Morin, “o homem é um ser cultural por natureza, por ser um ser natural por cultura" (p. 86), tornando a diferenciação entre o que é próprio da natureza e o que é próprio da cultura um "paradigma perdido".

A abertura desta falta de acabamento imprime na hominização uma espécie de errância simbólica caracterizada por seu aspecto demens. As práticas de sepultamento e as pinturas préhistóricas dão indícios de que seria a "consciência de morte" o ponto fulcral da constituição simbólica do ser humano. O sepultamento de corpos nos túmulos mais antigos, segundo Morin,

\footnotetext{
${ }^{19}$ Não obstante Gilbert Durand inaugurar esta antropologia do imaginário, tal campo é devedor da antropologia simbólica, uma das vertentes da antropologia cultural. A antropologia simbólica, por sua vez, dialoga com o campo da filosofia, mais propriamente com a antropologia filosófica, inaugurada por Max Scheler, cujo problema fundamental, em uma releitura kantiana, é “o que é o homem?”. A partir de Ernst Cassirer (1994) e seu animal symbolicum além dos estudos transdisciplinares do Círculo de Eranos (1933-1988) são abertas diversas frentes de estudo dos processos simbólicos ancorados nos "métodos possibilitados pela convergência muito profícua entre a fenomenologia e a hermenêutica simbólica” (FERREIRA-SANTOS; ALMEIDA, 2012, p. 84).

${ }^{20}$ Este conceito de Edgar Morin sugere um aspecto irracional, simbólico e delirante na própria condição humana, sugerindo que na constituição do que é o homem concorrem a razão e a sensibilidade.
} 
sugere que não era somente a preocupação objetiva com a decomposição dos cadáveres o que levava os hominídeos a enterrarem os mortos, mas a eminência de uma "cerimônia fúnebre". Mortos encontrados em posição fetal, deitados sobre flores, ossos pintados com ocre ou presença de armas e alimentos junto aos corpos sugerem a consciência do tempo na expectativa de alguma "continuidade" da existência que se substanciaria no mito e na magia: "há todo um aparelho mitológico-mágico que emerge no sapiens e que se encontra mobilizado para enfrentar a morte" (p. 95). A superação simbólica da morte seria, então, o nascedouro da cultura. Tanto a crença no renascimento do corpo quanto sua sobrevivência como espectro corporal mobilizam o imaginário humano que reconhece objetivamente a morte e a resolve e supera subjetivamente nos mitos, nos ritos e na magia:

\footnotetext{
o Homo sapiens é atingido pela morte como por uma catástrofe irremediável, que vai trazer consigo uma ansiedade específica, a angústia ou horror da morte, que a presença da morte passa a ser um problema vivo, isto é, que trabalha a sua vida. Tudo nos indica igualmente que esse homem não só recusa essa morte, mas que a rejeita, transpõe e resolve, no mito e na magia (MORIN, 1973, p. 95).
}

A brecha antropológica que se interpõe no halo entre a dimensão objetiva e a dimensão subjetiva face à morte caracteriza e possibilita a individualização pela consciência de si e ao mesmo tempo estabelece um fortalecimento comunitário pelos laços afetivos. O que confere o demens ao homem é senão a ambiguidade e a incerteza em relação ao ambiente do qual precisa retirar seu sustento e se proteger face a angústia de uma morte eminente. Nesse caso, o homem se coloca num universo de escolhas (tentativa e erro) em que a errância firmará uma zona de incerteza e indeterminação.

Marcado pela embriaguez do excesso, o demens está em várias manifestações, incluindo "a festa, a dança, o riso, as convulsões, as lágrimas, o gozo, a embriaguez, o êxtase" (MORIN, 1973, p. 106). Assim sendo, a desmedida e a desordem convivem com o gesto austero de positivação do pensamento. O desvio e a loucura deste homem ancestral se desenvolvem solidárias de suas conquistas: expansão e extensão demográfica, complexificação e aceleração das técnicas, construção de um pensamento empírico-lógico, desenvolvimento de uma sociedade mais complexa. Portanto, a razão sensível surge no âmago deste ancestral oscilante sapiens-demens: "somos obrigados a procurar qualquer ligação consubstancial entre o Homo faber e o homem mitológico; entre o pensamento objectivo-técnico-lógico-empírico e o pensamento subjectivo-fantástico-mítico-mágico" (p. 110).

A premência do aspecto simbólico do homem, no âmago da cultura, recorre ao homo symbolicus (CASSIRER, 1994), traduzindo antropologicamente o que Maffesoli (1998) ressalta 
no homem. Ao mesmo tempo em que reanimar o simbólico no homem remete ao seu aspecto animal de desordem e demência, assinala, paradoxalmente, sua diferenciação radical em relação às outras espécies: "o animal possui uma imaginação e uma inteligência prática, enquanto apenas o homem desenvolveu uma nova forma: uma imaginação e uma inteligência simbólicas" (p. 60). Nesse caso, o animal symbolicum agencia os signos produzindo uma "linguagem emocional" diferente de uma "linguagem proposicional", o que o diferencia dos animais. A universalidade e a variabilidade dos símbolos abrem o caminho para uma cultura propriamente humana.

\subsubsection{Uma hermenêutica simbólica}

As produções simbólicas, suas formas de rastreamento e sua aptidão em roçar o sagrado são controversas no seio da cultura ocidental e no universo acadêmico, elegendo um sem número de autores que abordam o simbolismo de maneiras diversas entre si, ganhando contornos filosóficos, teológicos, psicanalíticos, antropológicos, semióticos, pedagógicos, literários etc. Um grande aglutinador e irradiador de contribuições no tratamento do simbolismo partiu do Círculo de Eranos que, segundo Alberto Filipe Araújo e Horst Bergmeier, pretendia a

\footnotetext{
instauração de um "novo humanismo" estimulado por uma hermenêutica total que muda o ser humano, visto que também ela deve ser encarada como uma técnica espiritual que engendra uma mudança ao nível do ser. Além disso, este novo humanismo é o corolário de um profundo e rico diálogo entre os orientalistas, etnólogos, psicólogos de profundidades e historiadores das religiões em torno da ideia do homem integral. Para melhor darem conta dessa ideia, e a aprofundarem, os membros de Eranos atribuíram um interesse hermenêutico acrescido ao mundo dos símbolos, dos mitos, das figuras divinas e às técnicas místicas (ARAÚJO; BERGMEIER, 2013, p. 105, grifo nosso).
}

De origem anarquista e autogestionária, o Círculo de Eranos se desenvolveu em Ascona (Suíça) durante o século XX, tendo sido um importante espaço de reunião de livres pensadores em caráter multidisciplinar. Iniciado por Rudolf Otto e Carl Gustav Jung, teve a participação de Mircea Eliade, Joseph Campbell, Henri Corbin e Hélder Godinho. Influenciado pela tradição de Eranos (principalmente pela psicologia das profundezas de Jung) e pelo pensamento de Gaston Bachelard, Gilbert Durand foi um dos autores importantes a trabalhar com o simbolismo sob o prisma do imaginário.

Durand (2012) se esforçou na fundamentação antropológica de uma arquetipologia dos símbolos objetivando uma espécie de filosofia do imaginário, uma fantástica transcendental, recobrando o espaço da fantasia e do símbolo como potências de conhecimento. Para Durand, 
o corte se dava entre hermenêuticas redutoras e hermenêuticas instauradoras: "as que reduzem o símbolo a ser apenas o epifenômeno, o efeito, a superestrutura, o sintoma; e as que, pelo contrário, amplificam o símbolo, deixam-se levar por sua força de integração para ter acesso a uma espécie de supraconsciente vivido" (DURAND, 1988, p. 93).

Segundo Durand, as hermenêuticas redutoras podem ser qualificadas como iconoclastas porque rebaixam a imagem ao estatuto de signo (semiologia e antropologia estrutural), de alegoria (filosofia), de sintoma (psicanálise), de analogia. Neste caso, para Durand e para Paul Ricoeur, Freud, Lévi-Strauss, Nietzsche, Marx e Sartre promoveriam interpretações redutoras do símbolo, a passo que Eliade e Bachelard, por exemplo, levariam a cabo interpretações instauradoras. Além disso, Durand dirá que, além da necessidade de amplificar o sentido do símbolo $^{21}$, se pode trabalhar pela convergência das hermenêuticas. Ou seja, a interpretação simbólica requer uma abordagem transdisciplinar instauradora podendo trabalhar também com pensadores considerados redutores, conquanto se preserve a potência amplificadora do símbolo.

A conjunção de diversas constelações simbólicas e as relações dinâmicas entre diversos símbolos e constelações permitindo uma interpretação aberta configura o conceito de imaginário por nós adotado, compreendido como o "conjunto das imagens e relações de imagens que constitui o capital pensado do homo sapiens - aparece-nos como o grande denominador fundamental onde se vêm encontrar todas as criações do pensamento humano" (DURAND, 2012, p. 18). Wunenburger e Araújo (2006), por seu turno, apresentam uma importante desambiguação lexical ${ }^{22}$ quanto aos níveis de formação das imagens compreendendo o que chamamos imaginário como imaginal, de modo a diferenciar uma abordagem instauradora das imagens do uso corrente da palavra "imaginário" como produto ficcional da imaginação humana:

\footnotetext{
a imagética [representação] poderia designar o conjunto das imagens mentais e materiais que se apresentam antes de mais como representações do real, apesar das distâncias e das variações involuntárias ou voluntárias em relação ao referente [...] a imagem duplica assim o mundo a fim de memorizá-lo, deslocá-lo ou estetizá-lo [...]; o imaginário [fantasia/ficção] engloba as imagens que se apresentam como substituições de um real ausente, desaparecido ou inexistente, abrindo deste modo um campo de representação irreal [...]; o imaginal [esquemas, arquétipos, mitos] (do latim mundus imaginalis e não imaginarius) remeteria antes para representações metafóricas a que poderíamos chamar sobre-reais, uma vez que estas têm a capacidade de serem autónomas como objetos, colocando-nos simultaneamente na presença de formas sem equivalentes [...] o imaginal, enquanto correlação da imaginação criadora,
}

\footnotetext{
${ }^{21}$ Do alemão sinnbild: siin (sentido) e bild (forma). Do grego symbolon: syn (reunir) e bolos (partes). Nesse caso, o símbolo se define, em uma compreensão ampla, pela reunião das partes (seus sentidos e suas formas).

${ }^{22}$ Para uma compreensão mais profunda e completa deste léxico e das definições que concernem ao campo do imaginário consultar "Nota introdutória: da imaginação criadora ao imaginário" na obra Os trabalhos da imaginação: abordagens teóricas e modelizações (BAPTISTA, 2017).
} 
realiza o plano superior do simbolismo que actualiza imagens epifânicas com um sentido que nos ultrapassa e que não se deixa reduzir nem à reprodução nem à ficção (WUNENBURGER; ARAÚJO, 2006, p. 23-24, grifo nosso).

A imagem, com a qual o imaginário durandiano trabalha, "assume o seu estatuto honorável de 'forma simbólica' (Ernst Cassirer) que vale por si própria, mas que não vale para si, senão ela não seria símbolo de coisa alguma" (WUNENBURGER, ARAÚJO, 2006, p. 3031). Outrossim, a imagem em sua forma simbólica engloba o pensamento e as manifestações do símbolo de maneira que as teorias, os sistemas filosóficos, os conceitos, os axiomas, as expressões da linguagem seriam imagens ou símbolos. A definição recíproca e sinonímica de símbolo e de imagem remete à ultrapassagem do signo formal para os meandros de uma apreensão inefável, material maior da imaginação material: “imagem simbólica é transfiguração de uma representação concreta através de um sentido para sempre abstrato. $\mathrm{O}$ símbolo é, portanto, uma representação que faz aparecer um sentido secreto; ele é a epifania de um mistério" (DURAND, 1988, p. 15, grifo nosso).

Tendo seu significado exilado, a imagem simbólica se mostra por meio de sua porção visível, o significante. A linguagem escrita é composta de signos que sinalizam, como significantes, seus significados. Recusando uma interpretação mecânica do símbolo como signo as hermenêuticas instauradoras entreveem na parte visível seus significados poéticos, epifânicos. Ainda no terreno léxico, Wunenburger (2007) desambigua a terminologia do imaginário afastando noções como mentalidade, mitologia, ideologia, ficção, analogia, temática, imagética e imaginal, restando como definição

um conjunto de produções, mentais ou materializadas em obras, com base em imagens visuais (quadro, desenho, fotografia) e linguísticas (metáfora, símbolo, relato), formando conjuntos coerentes e dinâmicos, referentes a uma função simbólica no sentido de um ajuste de sentidos próprios e figurados (WUNENBURGER, 2007, p. 11).

A recuperação da imagem simbólica como potência em Gilbert Durand procura reabilitar a imagem do que chama de "iconoclastia ocidental", que a renegou a um estatuto de menoridade, a compreendendo como transcendência infundada, pensamento indireto ou imaginação abrangente:

à presença epifânica da transcendência, as Igrejas oporão dogmas e clericalismos; ao "pensamento indireto", os pragmatismos oporão o pensamento direto, o "conceito" [...] diante da imaginação abrangente, "senhora do erro e da falsidade", a ciência construirá as longas correntes de razões de explicação semiológica, assimilando aliás estas últimas às longas cadeias de "fatos" da explicação positivista [...] esses famosos 
"três estados" sucessivos do triunfo da explicação positivista são os três estados da extinção do símbolo (DURAND, 1988, p. 24).

Nessa direção, o símbolo se distancia do signo à medida que este último se mostra arbitrário e adequado, quase como sinal de entendimento direto e restrito: "no símbolo constitutivo da imagem há homogeneidade do significante e do significado no seio de um dinamismo organizador e que, por isso, a imagem difere totalmente do arbitrário do signo" (DURAND, 2012, p. 29). A analogia (real/irreal) do símbolo roça a metáfora viva e poética, uma vez que esta ilumina economicamente o significado. Portanto, em nossa perspectiva, o símbolo emerge de seu caráter semântico, profundo e epifânico.

A imaginação criadora é a faculdade mental que assume função simbólica operando os símbolos mediante o repositório do imaginário: "a imaginação se revela como o fator geral de equilibração psicossocial" (DURAND, 1988, p. 77). Estabelecendo uma dialogia entre o biopsiquismo e o plano sociocultural, conforme a qual se dá a gênese recíproca das imagens entre as criações psíquicas do sujeito e as influências do meio -, o trajeto antropológico será a “incessante troca que existe ao nível do imaginário entre as pulsões subjetivas e assimiladoras e as intimações objetivas que emanam do meio cósmico e social" (DURAND, 2012, p. 41). Assim sendo, a criação imaginante se realiza dialogicamente entre a apresentação do objeto forjada pelo sujeito e as intimações anteriores que o meio confere a ele próprio.

A característica fundamental da imaginação responde à finitude do ser. Em face da morte e do tempo o ser humano experimenta uma angústia existencial. Essa consciência de si marcada pela ameaça de apagamento e fruída com a morte no horizonte e com o tempo em seu encalço constrói a função do eufemismo: as construções simbólicas seriam, portanto, tentativas de vencer, ornamentar ou domesticar o destino e a morte. Gilbert Durand (2012) busca nos gestos primordiais da reflexologia (BETCHEREV, 1913; 1933; BETCHEREV et al., 1926) as intimações primevas dos símbolos, batizadas de dominantes reflexas.

A primeira dominante reflexa corresponde ao gesto de verticalidade (postural) cujos esquemas são antitéticos: separar e subir. Mediante estes esquemas são engendrados os arquétipos $^{23}$ de pureza, claridade, das alturas, como a luz, o ar, a arma, o céu, o cume, o herói,

\footnotetext{
${ }^{23}$ A definição de arquétipo pode ser encontrada em Jung: “essas reações e impulsos parecem ser de natureza muito íntima, e, nós os consideramos apenas uma forma de comportamento idiossincrático. Na verdade, eles fundamentam-se num sistema instintivo pré-formado e sempre ativo, característico do homem. Formas de pensamento, gestos de compreensão universal e inúmeras atitudes seguem um esquema estabelecido muito antes de o homem ter desenvolvido uma consciência reflexiva" (JUNG, 2008, p. 94, grifo nosso). A ideia, por exemplo, equivale simbolicamente a um arquétipo. Lembremos que Jung relaciona os arquétipos ao inconsciente coletivo: "como os instintos, os esquemas de pensamentos coletivos da mente humana também são inatos e herdados. E agem, quando necessário, mais ou menos da mesma forma em todos nós” (p. 93).
} 
o anjo, a asa etc., e os símbolos do sol, do mantra, da escada, da águia, da pomba etc. A estrutura de sensibilidade heroica (ou esquizomorfa) se realiza na exclusão e na distinção sendo, portanto, dualista.

A segunda dominante reflexa corresponde ao gesto de nutrição (sucção labial) e ao gesto de digestão. Seus esquemas são de confusão (descer, possuir, penetrar) com arquétipos do profundo, calmo, quente, íntimo, escondido, como o microcosmo, a criança, o animal, a noite, a mãe, o alimento, a morada, a mulher etc. São símbolos da estrutura de sensibilidade mística (ou antifrásica) o ventre, o véu, a caverna, o berço, as pedras, o túmulo, o vinho etc.

Já a estrutura de sensibilidade sintética (ou dramática), sob a terceira dominante reflexa, a copulativa (rítmica sexual), se realiza nos esquemas de amadurecimento e progresso ou de ressurgimento e circularidade. Seus arquétipos são os dinamismos futuros e passados, como o filho, a roda, a cruz, a lua, o andrógino, a árvore etc.

As estruturas de sensibilidade mística e dramática se organizam no regime noturno e a estrutura de sensibilidade heroica se organiza no regime diurno do imaginário durandiano. Assim sendo, a eufemização das metáforas solares se caracteriza pelo combate ao tempo, as metáforas dramáticas procuram a domesticação do devir e as metáforas de intimidade ornamentam e embelezam o tempo.

Tomando como direcionadores os gestos de equilibração e eufemização, caros ao imaginário durandiano, a jornada interpretativa ${ }^{24}$ construída por este que escreve, em confronto com seu objeto de estudo, demanda o vínculo com uma a ancestralidade ${ }^{25}$ acentuada nos textos nassarianos. Portanto, nossa interpretação literária está ancorada na convergência entre as hermenêuticas instauradoras de Gilbert Durand (2012) e de Paul Ricoeur (2015), acrescidas de recortes do pensamento de Georges Bataille (2014; 2015), apropriações da psicanálise freudiana e lacaniana, diálogos com a crítica literária, dentre outros recursos interpretativos que empregamos na análise do universo nassariano.

\footnotetext{
24 “A jornada interpretativa é, precisamente, esse momento antropológico em que eu deixo o gabinete, a comodidade do lugar-comum, o meu lugar, o meu locus (lugar) e domus (lar) e, então, viajo. Vou contemplar essa paisagem desde o seu interior, vou dialogar com as pessoas concretas lá. E aí, então, nessa explosão de sentidos, é que ocorrem as descobertas da constituição da nossa alteridade, numa reconstituição pessoal de sentidos" (FERREIRA-SANTOS; ALMEIDA, 2012, p. 44).

${ }^{25}$ Desambiguando tradição e ancestralidade podemos dizer que "o contexto imediato da palavra tradição remete a algo estático, coercitivo e obediente. Contudo, pode se ligar àquilo que o nosso corpo-memória armazena e onde se reconhece, pode remeter a um universo mítico com conotações ancestrais, estranho ao ditame das regras" (VANEAU, 2016, p. 89).
} 


\subsubsection{Aportes metodológicos}

A abordagem metodológica sugerida por Gilbert Durand (1996) é a mitocrítica, que estabelece um passo-a-passo que vai do símbolo ao mito diretor ${ }^{26}$ de uma época, o que corresponde a mitanálise. Durand direciona sua interpretação na busca pelas recorrências simbólicas que se apresentam na obra estudada como mitemas (unidades mínimas de significação mítico-simbólicas). A repetição dos mitemas se manifesta como metáfora obsessiva do autor estudado possibilitando a captação gradativa das matizes simbólicas e míticas de uma obra, de um autor e até mesmo de uma época, o que demanda um trabalho de mitanálise.

Começa-se pelo título das obras tomadas como objeto interpretando-se suas significâncias simbólicas no confronto com a própria obra. Na sequência, se passa para a apreciação de uma obra de dimensões reduzidas do autor. Em seguida, segue-se expandindo para um conjunto maior de textos do autor. Por conseguinte, aborda-se a obra completa de um autor. Adentrando na bacia semântica por uma mitanálise (filosofia empírica) se pretende dar conta do tempo e do espaço cultural em que produziu o autor. Finalmente, "se o terreno de investigação abarca um espaço e um tempo que tocam a imemoriabilidade, pode descobrirse, então, a dinâmica de um mito em todas as suas matizes, em toda a sua amplitude" (DURAND, 1996, p. 248).

Utilizaremos em nossa interpretação o dinamismo simbólico do imaginário, sua natureza eclética, para que possa fazer uso de uma hermenêutica convergente ao tratamento de Paul Ricoeur (2015). De modo geral, assumiremos o "crescendo" (MAFFESOLI, 1988, p. 16) na obra de Raduan Nassar partindo da Safrinha (contos), passando por Um copo de cólera e desaguando em Lavoura arcaica. Recuperamos, afinal, a noção de mundo-do-texto, formulada por Paul Ricoeur (2011), para que se possa adentrar na trama das obras e extrair delas suas inter-relações simbólicas:

a ideia de um texto literário em geral, um texto narrativo em particular, que projeta diante de si um mundo-do-texto, mundo possível, sem dúvida, mas no entanto mundo enquanto estágio onde poderia me manter e morar para executar meus possíveis mais próximos. Sem ser um mundo real, esse objeto intencional ambicionado pelo texto como seu texto exterior constitui uma primeira mediação na medida em que um leitor

\footnotetext{
${ }^{26}$ Absorvemos o conceito de mito, conforme enunciado por Mircea Eliade: "o mito conta uma história sagrada; ele relata um acontecimento ocorrido no tempo primordial, o tempo fabuloso do 'princípio' [...] o mito narra como, graças às façanhas dos Entes Sobrenaturais, uma realidade que passou a existir, seja uma realidade total, o Cosmo, ou apenas um fragmento: uma ilha, uma espécie vegetal, um comportamento humano, uma instituição. É sempre, portanto, a narrativa de uma 'criação': ele relata de que modo algo foi produzido e começou a ser" (ELIADE, 1989, p. 11). Neste caso, para Gilbert Durand (1996), o mito diretor seria a narrativa dominante na conformação simbólica de determinada sociedade em um período histórico específico.
} 
pode se apropriar de algo que não é a intenção perdida do autor atrás do texto, mas o mundo do texto diante do texto (RICOEUR, 2011, p. 34, grifo nosso).

Nessa direção, entre a intenção do escritor e a intepretação do leitor abre-se o mundodo-texto, com o qual este leitor dialoga como mundo possível de sua alteridade imaginando-se a viver naquele universo. Assim poder entrar em contato com uma teoria do autor que o próprio Raduan nos mostra: "suponho que exista em toda obra uma teoria subjacente do autor, podendo ser apreendida pelos que eventualmente se interessem por ela" (NASSAR, 1994, p. 34). O "mundo-do-texto" se abre, portanto, como alternativa de potência de vida, como vivificação do real, justamente porque supera o cotidiano como espelho deste mundo, a circulação sanguínea: "eu falo sobretudo como leitor. Um texto vale quando sinto nele a vibração da vida, quando tem circulação sanguínea, um texto com o qual eu possa estabelecer um mínimo de interlocução" (NASSAR, 1995, p. 1).

Cabe a nós acrescentar que a recorrência simbólica de Durand (1996) é entendida por Paul Ricoeur como repetição: “essa dimensão do símbolo não pode ser reconquistada a não ser pela 'repetição' da experiência que o mito explicita. É, portanto, até ela que devemos tentar chegar" (RICOEUR, 2015, p. 23). Para Ricoeur o que se repete na linguagem dos textos da tradição ocidental é uma confissão que o autor procura deslindar em uma fenomenologia específica da simbólica do mal. Nesse caso, a própria linguagem é a confissão. Nela residem os símbolos primordiais do mal: a mancha, o pecado e a culpa. Ressalte-se, por fim, que a repetição de Ricoeur se dá em simpatia e imaginação:

\begin{abstract}
A expressão sui generis que Ricoeur utiliza é "répétition en imagination et en sympathie", a qual é utilizada para tentar conciliar o método eidético da fenomenologia com a crença da consciência religiosa. Esta repetição não significa que Ricoeur esteja a atribuir à fenomenologia husserliana um psicologismo que ela não possui e que, de resto, critica. No entanto, pressupõe para que se consigam analisar os fenômenos que ocuparão este livro [A simbólica do $\mathbf{m a l}$ ], o método filosófico, de alguma forma, tenha de tentar colocar-se no lugar da consciência religiosa para poder reconstituir a experiência que pretende descrever. Isto é feito através de um exercício imaginativo, que nos recorda as variações imaginativas husserlianas, e pressupõe uma atitude de "simpatia", isto é [...] imaginar partilhar o ato de adesão da consciência religiosa à crença, sem com isso ser obrigado a crer efetivamente (RICOEUR, 2015, p. 20, nota dos tradutores; grifo nosso).
\end{abstract}

Decerto que a simpatia e a imaginação de Ricoeur são atitudes na direção da epifania do símbolo, de sua possibilidade instauradora e ampliadora de sentidos. Assim sendo, nesta dissertação apresentamos as repetições ou recorrências simbólicas encontradas na obra completa do escritor brasileiro Raduan Nassar. 
Neste capítulo apresentamos nossa fundamentação teórica e os aportes metodológicos por nós adotados. Após este percurso avançaremos para o segundo capítulo no qual traçaremos um panorama do universo nassariano seguido de uma aproximação de seus textos ao imaginário da queda. Além disso, no próximo capítulo estudaremos os contos "Aí pelas três da tarde", "Mãozinhas de seda" e o ensaio "A corrente do esforço humano". 


\section{ERRARE HUMANUM EST}

Figura 1 - Aquele bando de moços e moças

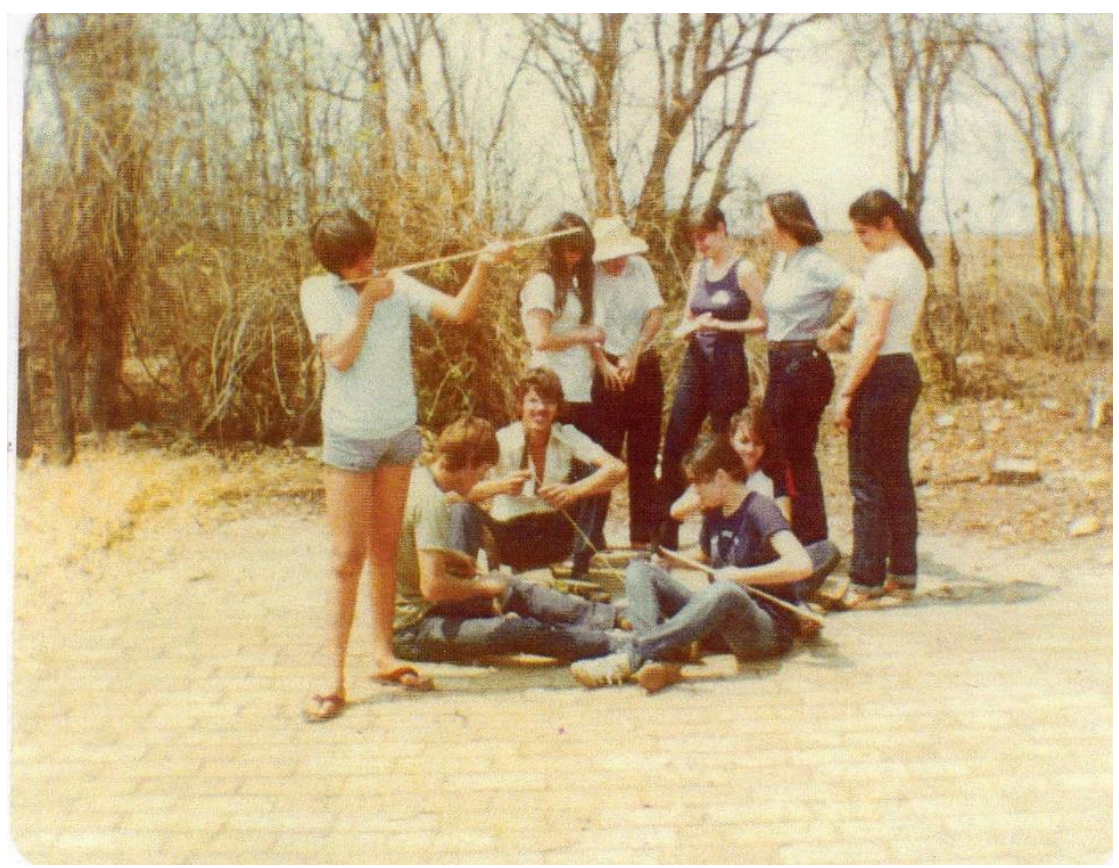

Fonte: arquivo familiar (1981)

Nesta fotografia sacada em outubro de 1981, Gerson, Arlete, Magali, Rosângela, Maria Terezinha (Tere) e Palmira (em pé), Ângelo (Bimbo), Robson, Claudeni e Margareth (sentados). Entretidos em um trabalho manual, minhas tias, meus tios, seus primos e amigos, sete anos antes de eu vir ao mundo, gozam a flor de suas idades na imensidão remanescente de um Brasil ainda rural. Alheios como podiam da modernidade tecnocrática, sobejavam desavisadamente as “promessas de amor suspensas na pureza de um amor maior".

Ao fundo, o chão sagrado e profano de onde se multiplicaram histórias e mitos familiares, reunindo em uma cosmovisão própria elementos condimentados pela imigração italiana e árabe maculada nos resquícios escravagistas. O "Sítio Bairrinho", hoje não mais propriedade dos Cremascos, Zandona e Rossi, cumulava as virtudes primevas de universo idílico, de onde brotavam a simplicidade rústica de povoado e um imaginário voluptuoso de possessões e espíritos nas memórias dos mais velhos. Naquele período em que muito acontecia num país militarizado e num mundo dividido, o isolamento dos dramas e das paixões na propriedade rural compunha o cenário de uma trama ensimesmada, em que pesava as terras da região de Piracicaba (SP), em uma fazendola entre Tietê e Saltinho. 
Figura 2 - Nada de porraloquice!

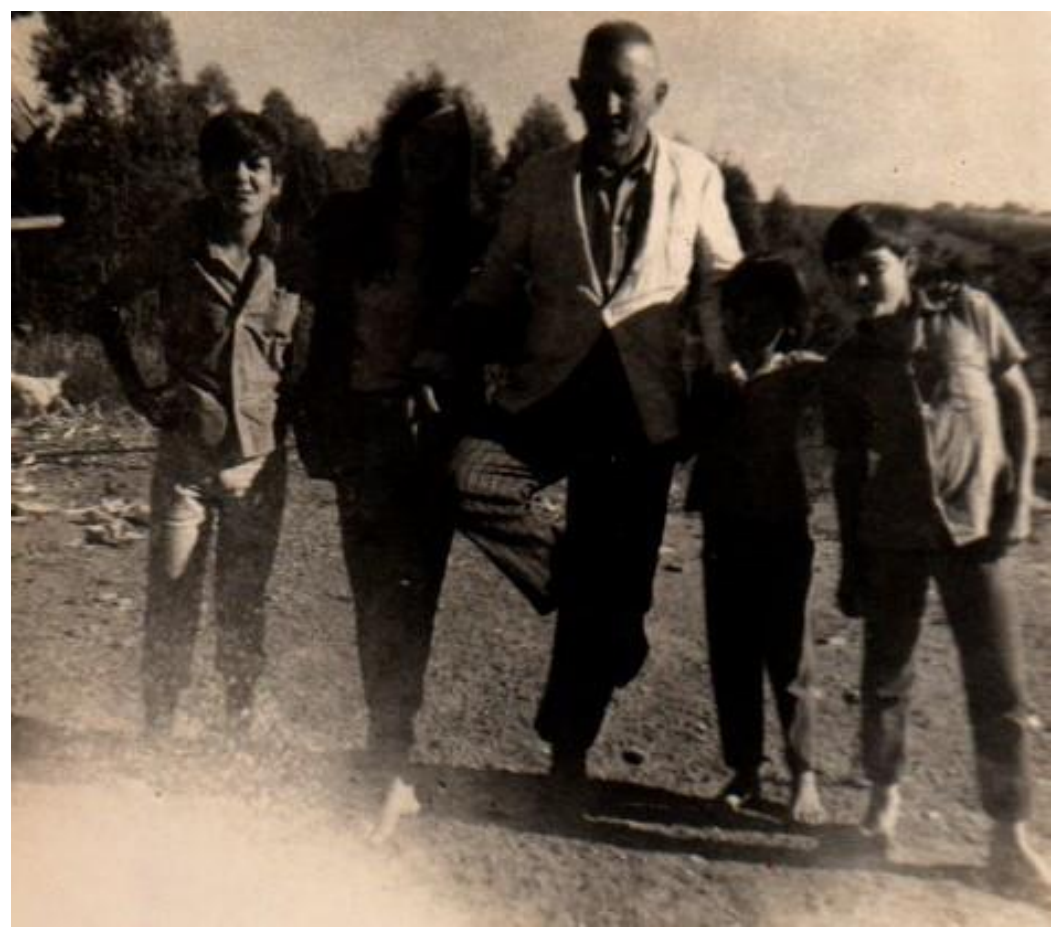

Fonte: arquivo familiar (1969)

Da esquerda para a direita, Gumercindo, Célia, José, Neura e Valter. Pouco sei acerca de meu bisavô, José Zandona, referido sempre como "Nono". A ausência de nome próprio reforça nos ancestrais a condição de ideia, que sobrevive gerações e gerações como um conceito turvo, deslizando tempo a tempo nos confins da memória e predizendo através de ângulos e lentes obtusas toda a água represada nas linhas da história comum de muitos anônimos que na terra roxa desembarcaram com parcas posses e ricos sonhos.

Este capítulo apresenta a literatura nassariana, articulando aspectos temáticos, estilísticos e estruturais na confluência entre o imaginário de queda e um processo de deseducação. Inicialmente, apresentamos um panorama do universo de Nassar com Em solo turvo: territórios nassarianos. Seguimos em Tessituras da queda, onde localizamos e traçamos as primeiras considerações sobre o arquétipo da queda nos textos de Raduan. No tópico Desnudamento analisamos os contos "Aí pelas três da tarde" (TT) e "Mãozinhas de seda" (MS). Na sequência, abordamos o ensaio "A corrente do esforço humano" (CEH). Terminamos com o tópico Humano, no qual articulamos tematicamente os três textos. A escolha destes textos para abrir as análises se deve por serem trabalhos panorâmicos, por meio dos quais podemos alcançar outros textos de Nassar e delinear processos de análise. Além disso, “TT" e "MS" são, respectivamente, o primeiro e o último trabalhos publicados pelo autor. 
"CEH”, por sua vez, é seu único ensaio. Nesse caso, através destas análises iniciais prepararemos o terreno para o tratamento dos demais textos nos capítulos seguintes.

\subsection{EM SOLO TURVO: TERRITÓRIOS NASSARIANOS}

É comum intérpretes da obra de Raduan apontarem a dificuldade de classificá-lo, enquadrá-lo ou aproximá-lo de outras obras e autores. Sabe-se da influência de Francis Bacon, Nietzsche, Dostoievski e de Graciliano Ramos, mas nada que aponte uma filiação estilística. No disperso cenário contemporâneo, a singularidade de sua obra sugere uma composição eclética de referências vinculadas a universos distintos: clássicos da literatura, filosofia, teorias e práticas políticas, terminologias científicas, vocabulário da agricultura, temas religiosos, elementos da alquimia, jornalismo. Tal amálgama não incorre, contudo, em justaposição ou prolixidade, mas em uma escrita concisa, cuja simplicidade impõe ao leitor um rigoroso emprego de símbolos e metáforas que concorrem para constituição do imaginário ocidental, emergindo das idiossincrasias do contexto brasileiro. Por isso, suas estórias de mundos, obras e homens alcançam a aldeia comum da intimidade de cada um.

O fluxo de consciência, o modo singular de pontuação, o trabalho vocabular, o flerte poético e sonoro com as palavras são alguns traços característicos de seus textos: "o projeto de Raduan Nassar consistiria então em trapacear a língua, ouvindo-a fora de seu poder fascista, percebendo aí suas virtualidades e possibilidades, trabalhando com o signo: mexendo com sua 'casca' (significante) e com sua 'gema' (significado)" (COIMBRA, 2011, p. 45). Nesse caso, de seus textos afloram questões que desestabilizam e dispersam ordens e tradições, compondo sutis, porém, densas reconfigurações de espaços de poder. A mecânica da linguagem de Raduan pende para a confusão, a intimidade e o labirinto, conferindo aos caminhos de leitura uma tortuosa procura por imagens que, em sua simplicidade, se ampliam a cada leitura.

Sabe-se que Raduan enxerta em seus textos vários trechos de outros autores ${ }^{27}$. Há outras menções perceptíveis não manifestas, como é o caso de Autopsicografia, de Fernando Pessoa, que aparece em $C C$ : “ator, eu só fingia, a exemplo, a dor que realmente me doía" (NASSAR,

\footnotetext{
${ }^{27}$ Nas primeiras edições de Lavoura arcaica e Um copo de cólera Raduan acrescentou notas ao final comentando algumas referências literárias que fazia. Em CC indica Jorge de Lima (Espírito Paráclito), Fernando Pessoa (Ouvi contar que outrora, quando a Pérsia) e James Joyce (Um retrato do artista quando jovem). Já em LA dá créditos à parábola bíblica do filho pródigo - localizada no Evangelho Segundo São Lucas - à parábola do faminto $(O$ Livro das Mil e Uma Noites), Thomas Mann, Novalis, Walt Whitman, André Gide, Jorge de Lima, Almeida Faria, agradecendo ainda Antonio Olavo Pereira. As menções, omitidas nas edições seguintes, retornam na Obra completa (2016).
} 
2016, p. 235; CC). Raduan confunde as pistas de seu percurso, de modo que, nas edições seguintes as menções a outros autores desaparecem, sendo retomadas à frente.

Outro traço marcante da literatura de Raduan é o caráter pessoal e biográfico, como também observam Masé Lemos (2003) e Augusto Massi (2015). Tendo em vista a obra completa e o conjunto de entrevistas e depoimentos concedidos pelo autor, percebe-se que sua vida pessoal inspirou seus escritos, transmutando o biográfico no literário. De seus sete contos, dois livros e um ensaio, apenas "O ventre seco" (VS), "Hoje de madrugada" (HM) e "O velho" (V) não possuem dedicatória. As dedicatórias a seu pai, na primeira edição de $L A$, e à Heidrun Brückner e Modesto Carone, na primeira edição de $C C$, foram retiradas a partir das edições seguintes, não mais presentes desde então.

As personagens de Raduan são marcadas pela contradição, pelo erro e pela desordem: a paixão incestuosa, a malícia das pessoas da cidade pequena, a violência verbal, o desvelamento do poder. Sua literatura dialoga com o Regime Militar e com fenômenos da década de 1970, como o êxodo rural. Naquele contexto, a sociedade brasileira vivia um momento de grandes transformações. $L A$ e $C C$ foram publicados no mesmo contexto de repressão, sob o mantra do AI- $5^{28}$. Rosicley Andrade Coimbra ressalta que "a política militarista impôs uma espécie de toque de recolher a seus cidadãos, que foi estendido, sobretudo ao escritor e ao artista em geral, só que com maior violência, às vezes física, às vezes moral" (COIMBRA, 2011, p. 24). Coimbra destaca que, na esfera da literatura, além do boom de obras comerciais financiadas pelo controverso Plano Nacional de Cultura (1975), se viu florescer o realismo mágico e o realismo jornalístico, este último, compreendido como literatura engajada. Entretanto, a obra de Raduan, apesar de localizada no tempo, não é datada: "Nassar estaria engajado em favor do especificamente literário. O direito de usar recursos literários, de se deter no significante, e de deixar de lado, ainda que por um momento, a dita mensagem engajada, cujo significado seria sempre o mesmo: a evasão rumo a um futuro sem ditadura" (COIMBRA, 2011, p. 40).

A potência da palavra de Raduan é endereçada, dessa maneira, ao universal, à própria condição humana, já que interroga a possibilidade e os limites da liberdade e do poder. A denúncia da ordem que oprime vem acompanhada dos paradoxos da suposta contraordem que liberta. Se a literatura engajada entrevia no horizonte alguma redenção, Raduan investe em uma danação convivendo, de modo ambíguo e sinuoso, com esperanças e alegrias do cotidiano,

\footnotetext{
${ }^{28}$ Uma vez que os imaginários em circulação naquele período influenciaram as produções nassarianas, fica patente a pressão pedagógica (DURAND, 2012) que o imaginário exerce nas criações humanas, ressaltando a importância do contexto para a interpretação de sua obra (temporal) e evidenciando o caráter educativo do imaginário (atemporal).
} 
conquanto se preze a pessoa comum. Não deixa de denunciar e desvelar o poder e de colocar em evidência as minorias. A mulher e o feminino, por exemplo, são temas importantes no trabalho de Raduan. Nessa direção, somente o capítulo final de $C C$ e o conto "Monsenhores" (M) trazem narradoras femininas; já "Menina a caminho" (MC) apresenta uma garota como protagonista, embora escrito em terceira pessoa.

Seu tímido lugar de fala ganha amplitude quando notamos que o corpo, o mistério, o segredo e a sensualidade atravessam muitas passagens e textos, retratando, com isso, tudo o que é excluído da clareza racional e do progresso moral. O universo dos excluídos não se eleva com a figura de anti-heróis que, afinal, conseguem recompor e reequilibrar uma ordem assimétrica, mas como ambiente no qual toda matéria indistinta e confusa sustenta uma ordem que se vê eternamente exilada de uma sustentação metafísica: "meus textos carecem de um componente político, daí que quebram quando chegam ao limite. Houvesse aquele componente, terminariam em conciliação. Como eu mesmo não tenho nada de político, isso deve ter sido passado de alguma forma para os meus textos" (NASSAR, 1984, p. 9).

O espaço das narrativas de Raduan é genérico, possibilitando ao leitor o confronto entre as referências do autor e suas referências pessoais. "MC", "V" e "M" sugerem a cidade interiorana, que facilmente se materializa em Pindorama. $L A$ poderia se situar em uma fazenda no interior de São Paulo - o Mediterrâneo às margens de sua geografia insular. $C C$ poderia se passar nas imediações da Rodovia Raposo Tavares, em uma das muitas chácaras naquelas redondezas - como na casa comum dos dramas conjugais. Os demais contos podem, facilmente, transcorrer na própria cidade de São Paulo, mas também em outras metrópoles brasileiras. Esta imprecisa localização faz notar um afastamento do moderno e urbano, ganhando o ambiente rural para, sutilmente, se endereçar à própria condição humana. O desnudamento de "TT" também é o movimento de quem saí em viagem, partindo de São Paulo, em direção ao Mediterrâneo, entrevendo em seu itinerário uma rodovia qualquer que, em um ponto longínquo, alcança uma pequena cidade de imigrantes. Ao interpretar $L A$, André Luis Rodrigues destaca que

$\mathrm{Na}$ economia da narrativa, a alusão ao Mediterrâneo não é apenas referência às origens da família de André, mas também menção ao berço de nossa civilização. Nela, não há mais possibilidade alguma de retorno. Há muito foi o homem expulso do paraíso e não é mais realizável a integração plena na natureza e muito menos com o outro. A unidade foi e é perdida, e só restou a sua falta, o desejo sempre frustrado de reencontrá-la (RODRIGUES, 2010, p. 291). 
Além de ressaltar a condição humana, Rodrigues também nos remete à "obra pronta" de Raduan, que começava no lírico episódio “do Paribar ao Porto de Santos”. Talvez nosso viajante não venha de São Paulo, mas de Santos, de dentro de algum navio, como imigrante embarcado clandestinamente, originário de algum ponto do Mediterrâneo. Destas geografias tão amplas quanto sinuosas, emergem dramas familiares, conjugais, pessoais. A família e a intimidade são os ganchos de Raduan para interpelar a situação da humanidade:

essa instituição é o elo entre acontecimentos tão remotos como a fixação do homem e o surgimento da propriedade privada, o domínio da natureza e do outro e o consequente distanciamento de ambos, a instituição do trabalho e da vida em sociedade, e finalmente o estabelecimento das regras do matrimônio e as interdições delas decorrentes (RODRIGUES, 2010, p. 289).

O espaço de Raduan é confinado, seu tempo é restrito, fazendo de seus personagens criaturas sufocadas e cindidas, mas não por isso privadas de desejo, vontade de potência ${ }^{29}$ e ambição. Suas narrativas situam-se no microcosmo e desenvolvem-se em pequenas extensões de tempo. Mas esses circuitos de espaço e tempo facilmente tocam a amplidão de toda uma cultura, incorporando elementos que traduzem histórias e estórias, grandes e pequenos, povos e indivíduos, em pequenos relatos cotidianos, cujos objetos, alimentos e animais recobrem de segredo e enigma a trajetória humana, dispersa pelo mundo. O presente contrai e dilata, atingindo um passado longínquo, reenviando à antiguidade clássica, às três grandes religiões de expansão, ao passado colonialista.

As temáticas de Raduan reabilitam o mistério e ofuscam a luminescência que se poderia entrever na emancipação apregoada pelo discurso da abertura política, solidário do ideário iluminista. Por outro lado, põe em evidência mecanismos do poder e opressão sem melindres. Ao convocar o Mediterrâneo, Raduan coloca em cheque o presenteísmo e submerge na ancestralidade comum: "ao ligar inextricavelmente o lírico e o trágico ao narrativo, Raduan Nassar como que nos faz rememorar um tempo em que o pensamento ordenador ainda não

\footnotetext{
${ }^{29}$ No pensamento de Nietzsche a vontade de poder ou vontade de potência (Wille zur Macht) é central. Para este autor, a vida circula em torno desta vontade, a qual seu anfitrião e mensageiro por excelência é o corpo, uma vez que "só ele pode autossuperar-se; nele se encontra o princípio de toda a hierarquia. Cada impulso animado por uma vontade de potência procura dominar os outros e impor-se como mestre. Qualquer que seja o método empregado para combater a violência de um instinto, a decisão, a vontade de combatê-lo resulta de um processo inconsciente. Em toda luta, o essencial escapa-nos, nosso intelecto e nossa pretensa vontade são instrumentos cegos de um impulso que procura por outro para exercer sua potência, efetivar-se, dominar e criar novas interpretações. Isso porque a tendência fundamental da vida é vontade de potência, e o homem, uma pluralidade de vontades de potência" (DIAS, 2015, p. 241-242, grifo nosso). Estevão Azevedo (2015) reconhece a importância da filosofia de Nietzsche e deste conceito na obra de Nassar, definindo-o como "a multiplicidade de forças que só podem existir em oposição umas às outras e lutam por ampliar mais e mais seu espaço de dominação. Tudo no mundo e na vida, do inorgânico ao orgânico, seria redutível a esse impulso" (p. 36).
} 
havia separado abstratamente os gêneros, e mesmo um tempo ainda anterior em que poesia, música e dança eram uma só e mesma coisa” (RODRIGUES, 2010, p. 292).

Raduan põe em jogo antagonismos: a inocência infantil e a malícia, a integridade moral e a devassidão sexual, o desejo flamejante e a abstinência, a austeridade patriarcal e o incesto, a esperança política e o niilismo. Além disso, personagens antagônicos mostram em ações e discursos sua angústia interior. Tratando de $C C$, Rodrigues nos adverte:

\begin{abstract}
Sem prejuízo da aceitação da verossimilhança da tensão e do erotismo levados ao paroxismo na discussão extremada entre homem e mulher, a altercação pode também ser vista como dramatização dos tremendos embates do sujeito consigo mesmo, envolvendo, como é o caso de situações-limite como essa, troca de acusações, pesados insultos, ataques ferozes, injúrias, motejos, ridicularizações, como se o sujeito se desdobrasse a ponto de se engalfinhar com a própria imagem (RODRIGUES, 2010, p. 288).
\end{abstract}

Nesse caso, o antagonismo aparente que os textos de Raduan apresentam, geralmente se subsome em uma espiral de contradições apontando, ora para um fervilhar predisposto à explosão, ora para uma queda vertiginosa manifesta em gradações valorativas que vão, pouco a pouco, desmontando os embates externos e fazendo ver as próprias ambiguidades do sujeito. A circularidade dos textos nassarianos - apontada por Lemos (2003), Rodrigues (2010) e Tardivo (2011) - demanda tanto o registro cíclico quanto o registro de intimidade, como se o embate das contradições do sujeito se instalasse em uma quietude exilada. Assim, o movimento espiralado de seus textos manifesta-se, por exemplo, no espelho e no crepúsculo, remetendo ao jogo de luz e sombra colocado em curso: vontade-repouso, violência-intimidade, uniãodesunião, interdito-transgressão, razão-paixão, utopia-distopia, doença-cura, sagrado-profano. A dialogia entre esses contrários supõe sempre um terceiro que se abre em uma polifonia, apresentando a condição humana como charada insolúvel, cacoete trágico de um Deus enganador.

A ambiguidade do homem nassariano se manifesta, sobremaneira, na sexualidade e sua inerente relação com o pecado e com a culpa. $\mathrm{O}$ embate entre vontade de potência e o contrato social expressa, então, o impossível da existência, o irredutível âmbito obscuro do poder: o político e o sexual imbricados num jogo de incomunicabilidade que Raduan mostra não ser sintoma do tempo, mas marca inelutável da danação humana, sob os auspícios da tradição ocidental. 


\subsection{TESSITURAS DA QUEDA}

Repete-se na obra de Raduan uma crise moral que se desenha como angústia circular em seus contos, como violência discursiva em Um copo de cólera e como intimidade em Lavoura arcaica. O pecado e a culpa se fazem presentes na dinâmica interdito versus transgressão, na dialogia entre uma ordem opressora e as erupções de devaneio, do delírio e do transe, aos quais se avizinham metáforas sexuais. $\mathrm{O}$ universo dos valores, nesse caso, fundamenta a literatura nassariana.

Transitando pelo ambiente dos excluídos, seus textos mobilizam uma figura maligna que não cansa de se investir como parte da própria ordem, mostrando que a assepsia da ciência, da política, da ética não corresponde à natureza demens do humano. O mal dilacera a ordem e se coloca na base do mundo, lançando mão de um arsenal de imagens que expressam uma incomunicabilidade agonística, uma danação remota do sujeito cindido e martirizado pela culpa, pelo pecado e pela mancha, pela exclusão. Este eles, insinuando-se como parte do nós, marca o turvo cenário desenhado pelo apagamento dos anônimos.

Sobre esses escombros de civilização são assentados novos solos, colunas, muros, tetos e fronteiras, compondo tradições nas quais o dentro e o fora se confundem à medida que a vontade de potência das minorias reivindica sua ancestralidade e reintroduz paletas de cores apagadas na ordem vigente. Esse movimento de mudança revira as estruturas e refaz limites, possibilitando outras assimetrias e diferentes configurações. A paisagem que advém deste fervilhar de intenções e narrativas, é um terreno com demarcações imprecisas e maleáveis.

acho que uma camaradagem com o Anjo do Mal é um dos pressupostos da nossa suposta liberdade. Impossível deixá-lo de fora quando eu pensava em fazer literatura. Não se pode esquecer que ele é parte do Divino, a parte que justamente promove as mudanças. Seria mais este Anjo que está presente nos meus textos (NASSAR, 1996, p. 29).

A fenomenologia da confissão, de Paul Ricoeur (2015), entende que a transição entre a possibilidade do mal humano e a sua realização se podem captar no ato da confissão, que se repete nos textos das tradições judaico-cristã e helênica. É, precisamente, no espaço entre potência e ato que o mal se realiza, percebido pela ordem que o interpreta como aquilo que o é estrangeiro, diverso: em seu sonho de pureza, os valores tradicionais convivem permanentemente com a contestação, absorvida e classificada como ameaça e mancha.

A deseducação que o itinerário de Raduan nos permite ver decorre da ação desse mal, uma vez que as mudanças por ele promovidas vão de encontro a uma imagem fixa do mundo, 
fundamentada na metafísica. Ao desinvestir e decompor a ordem, Raduan também destitui a contraordem, deixando o errar humano em um titubear transitório e constante que nunca se reveste como progresso moral, pois sempre reintroduz ímpetos ora extintos. Assim, o imaginário da queda se constitui desde o estigma da exclusão e da humilhação silenciada até a implosão dos alicerces da ordem que sustentam as opressões. Ao trazer à tona timbres excluídos, Nassar expõe um gradiente de valores que convivem abafados pelas dualidades solares. A explosão dessa pletora, o imaginário da queda, perfaz a literatura nassariana colocando em evidência uma deseducação que não só destrona impérios, como questiona, de modo espiral, o próprio contradiscurso.

A filosofia da vontade de Ricoeur, por sua vez, se reveste em uma dialogia entre a finitude do ser falível e a infinitude do sagrado, imagem do Deus cristão. A confissão é materializada na palavra, tendo como pano de fundo o pecado original, origem mítica da cisão bem/mal e a moralização do tempo: "o conceito de pecado original não se situa no começo, mas no termo de um ciclo de experiência viva, a experiência cristã do pecado" (RICOEUR, 2015, p. 21). A proliferação de metáforas religiosas nos textos nassarianos amplia termos como pecado e culpa para terrenos distintos, como o é a política, a ciência, a literatura e a educação, deslocando a sustentação discursiva, impregnada de valores, para o campo apaixonado da disputa dogmática, dicotômica e bélica.

Para Ricoeur, o mal se constitui no entrever da relação do homem com a divindade, "o mal - mancha ou pecado - é o ponto franco, como que a 'crise' desse elo que o mito torna explícito à sua maneira” (p. 22). A narrativa mítica moraliza o mal e estabelece a eterna dívida do homem para com a divindade. Nietzsche (2005b), por sua vez, mostra que a experiência do esquecimento é substituída, historicamente, pela experiência das promessas. A vontade do homem, seu espaço de liberdade, é cerceada pela construção histórica da responsabilidade, transfigurada em culpa e agenciada entre sofrer e fazer sofrer.

O instinto de liberdade reprimido pelo contrato social, conforma a moral do escravo: não mais senhor de si o homem padece de um sofrimento irreparável pois nunca pode saldar a dívida com a divindade, está manchado pelo pecado original desde a gênese, no contexto da tradição cristã. O castigo eterno se compõe como autoflagelo, auto penitência. A salvação estaria, afinal, na graça e na supressão da vontade, desvinculando do ser humano sua própria materialidade corporal.

A imagem da besta sugere, ainda, que a beatificação do homem o transmutaria em figura etérea sem a suposta escravidão dos sentidos e instintos presentes em sua face animal. Este imperialismo dos sentidos, batizado de mal, convoca aquilo que é excluído do corpo, mas 
também do corpo social, projetando a metáfora para o plano das relações humanas da família, do casal, da cidade, do país. O mundo nassariano convoca vários ambientes nos quais circula essa estratificação entre bem e mal, conquanto se mimetiza a imagem da pureza no homem, adulto, branco, heterossexual, sem deixar de lado o arsenal teórico e estilístico que completa e reitera este ascetismo garantido à força.

Desdobrando o mal em Baudrillard, constatamos que "já não sabemos enunciar o Mal" (BAUDRILLARD, 1990, p. 93). A profilaxia asséptica do Estado moderno reprime, nas aparências, a vocação para o mal: "o direito à catástrofe. Direito essencial, fundamental - direito ao acidente, direito ao crime, direito ao erro, direito ao mal, direito ao pior e não apenas ao melhor: eis o que, bem mais do que o direito à felicidade, faz de você um homem digno" (p. 95). A sugestão de Baudrillard compraz nossa vida efetiva no reconhecimento das nossas partes feias e indesejáveis. Notadamente, o pior dos mundos está conosco diariamente e neste convívio construímos nossas obras e realizações, das mais duráveis e reconhecidas às mais efêmeras e insignificantes. À denúncia presente nos textos nassarianos convém uma deseducação que põe em evidência a violência dos desejos de cada pessoa em confronto com o outro. Porém, ao negar a presença visceral do poder na caracterização de cada personagem do cotidiano, as formas de tradição asséptica recorrem à moral do escravo, estribada na culpabilidade e em um silêncio sufocante.

ao dualismo da transcendência sucede a posição sonolenta [...] da divisão do mundo entre dois princípios, ambos incluídos neste mundo, aquele do bem e do espírito e aquele do mal e da matéria. A partir daí está dado sem contrapartida um império da ordem real que é uma soberania da servidão. Define-se um mundo onde a livre violência só encontra um lugar negativo (BATAILLE, 2015, p. 59).

Na perspectiva simbólica do imaginário, a questão moral está ligada às experiências concretas como a noção de mancha, de sujeira e impureza. Assim, a moralização do mal e a configuração da culpa tem sua matriz simbólica no acontecimento menstrual que, travestido em sua face lunar, traduz a feminilidade: "há um isomorfismo estreito que liga o sangue como água escura à feminilidade e ao tempo 'menstrual'. A imaginação [...] vai encaminhar-se imperceptivelmente através do conceito da mancha sangrenta e da nódoa para o matiz moral da culpa, que [...] o arquétipo da queda precipitará" (DURAND, 2012, p. 110). A dimensão arquetípica da queda transfigura os vestígios fluídos do corpo feminino em metáfora sexual e valorativa. Assim, simbolicamente, o sangue precipita outras secreções que constelam e gravitam em torno da mancha. Esses fluídos, recursos fisiológicos da mecânica corporal, remetem ao movimento e ao dinamismo da vida em seu aspecto mais cru, o que o imaginário 
da queda projeta em moralização, captando a ambiguidade entre os gestos de equilibração corporal e a rítmica da sexualidade, rebaixando o aspecto sensível do homem à impureza: "a mulher, de impura que era pelo sangue menstrual, torna-se responsável pelo pecado original" (DURAND, 2012, 115).

O conhecimento do bem e do mal, manifesto no fruto proibido, divide e dualiza o simbolismo ocidental: "a feminização da queda seria, ao mesmo tempo, a sua eufemização. $\mathrm{O}$ incoercível terror do abismo minimizar-se-ia no medo venial do coito e da vagina" (p. 116). Em Nassar é farta a presença da metáfora do ventre, marcando não só as imagens mais nítidas, como a menção ao sexo feminino, mas a própria noção de origem vem amalgamada em uma fluidez primordial que turva o nosso passado mítico e histórico. Por outro lado, o ventre convive com a imagem do coito, ora remetendo à violação de limites, ora indicando ritmos e modulações dos personagens e da narrativa.

Fenomenologicamente, com a feminização da queda, o feminino passa a ser entendido como possessão demoníaca e se endereça aos pecados: "a queda torna-se, então, símbolo dos pecados de fornicação, inveja, cólera, idolatria e assassínio" (DURAND, 2012, p. 114). Nesse caso, o que instala a crise de valores e configura miticamente o mal é o imaginário da queda, solidário da complementariedade com o bem: "a queda é, assim, simbolizada pela carne, a carne que se come, ou a carne sexual, unificadas uma e outra pelo grande tabu do sangue. Assim, o temporal e o carnal tornam-se sinônimos. Ocorre um deslize do especulativo para o moral. A queda transforma-se em apelo do abismo mortal, a vertigem em tentação" (p. 118). A polifonia das imagens da carne, do sangue e do sexo reveste os textos de Raduan mostrando a instauração de um tempo progressivo, que se investe sustentado pela fuga do abismo demandado pela carne. Mas este tempo progressivo que se insinua é prontamente demolido pela circularidade angustiante de seus textos que, além de questionarem a ideia de progresso, questionam a própria possibilidade de ética a ele vinculada: o homem não melhora, apenas vagueia no tempo, à sua sorte. Nesse caso, a corporeidade vai de encontro a esse progresso moral, à razão e à verdade.

O pecado original, metáfora da separação entre a luminosa verdade imutável e as trevas terríficas da mudança, remete ao imaginário da queda e ao mito adâmico. Conforme Ricoeur (2015), a origem mítica do mal humano endereça à figura de Adão, símbolo do próprio homem, comparado com Cristo na teologia do Segundo Adão. Traduzido como mito de origem no cristianismo, a queda sinaliza a falibilidade do ser humano e reafirma sua eterna dívida com a divindade, conquanto a literatura nassariana amplia este débito para outros âmbitos. A circularidade do mito permite reintroduzir Adão em Cristo e formular a redenção como sofrimento terreno, mácula de todo homem. Para Ricoeur a linguagem da confissão é a 
antevisão da luz: cegueira, equivocidade e escândalo. A experiência cega do penitente, então, se reveste de emoção, medo e angústia. Essa narrativa confessional traduz, portanto, os três símbolos fundamentais: a culpa, o pecado e a mancha, camadas da errância terrena do ser humano.

a "culpabilidade", no sentido preciso de sentimento de indignidade do núcleo pessoal
do indivíduo, mais não é que o ponto extremo de uma experiência radicalmente
individualizada e interiorizada; este sentimento de culpabilidade remete para uma
experiência mais fundamental, a experiência do "pecado" que engloba todos os
homens e designa a situação real do homem perante Deus, quer ele o saiba ou não.
É a entrada desse pecado no mundo que o mito da queda narra; é esse pecado que a
especulação sobre o pecado original tenta erigir em doutrina. Mas, por sua vez, o
pecado é a correção e até a revolução de uma concessão mais arcaica de falta, a da
"mancha" concebida como nódoa que infeta a partir de fora (RICOEUR, 2015, p. 24,
grifo nosso).

É assim que Deus, em Nassar, aparece muitas vezes como metáfora da autoridade, da lei, da regra e da ordem, como fundamento metafísico de doutrinas que excluem. O paralelo é significativo a ponto dos excluídos reivindicarem sua presença nessa mesma ordem, a passo que a complexidade das relações nunca possibilita sua completude, já que o excluído se inclui reivindicando-se como tal, mantendo-se em relação aos polos tradicionais de poder. Assim, a sensibilidade reclama sua participação nos processos racionais, o feminino reclama presença no universo masculino, ao mesmo tempo que a masculinidade revela sua face feminina, a razão mostra seu aspecto passional, recursivamente, criando e recriando camadas de experiência e de pensamento que perfazem a deseducação.

O que na metáfora solar aparece como nódoa, mancha - a paixão desequilibra a razão, a sexualidade desestabiliza a austeridade moral - é marcado e apontado como pecado, tipificado nos códigos de conduta do dia a dia. Quando se quer separar o pecador, se quer impedir a contaminação pela impureza de sua diferença, deslocando a metáfora do pecado para uma amálgama de traduções que inclui o desvio das referências: o que é o trabalho, o amor, o tempo, a liberdade? O diferente, contaminado com a mancha, se torna pecador, sendo exilado daquela comunidade, mesmo nela permanecendo. Essa ambiguidade entre pertencer e não pertencer a um cenário cultural é traduzida no que constela à volta da culpabilidade: angústia, perversão, dissimulação, ironia, violência, sexualidade, jogando o excluído em um halo ilegítimo, amargando no calor desse desterro a indeterminação e a provisoriedade que assinala o errar humano, seja constituindo em matéria aqueles que são errados, seja destituindo de telos o drama terreno, imerso em um deambular sem fim. 
Transitando no vocabulário da falta, mediante uma dialogia entre fenomenologia e História, Ricoeur (2015, p. 25) mostra a "passagem da mancha ao pecado e à culpabilidade". Assim, o autor procura essa simbólica nas "relações em profundidade": avistando o imaginário cultural judaico-cristão e helênico (nas "relações laterais"), mas localizando aí a mestiçagem cultural com antigo Oriente Médio (nas "relações retroativas"), denominado pelo autor como neopassado: "a restauração dos intermediários perdidos e a supressão tardia da distância" (p. 38). Nesse caso, a simplicidade das narrativas nassarianas indica, sorrateiramente, uma profusão de imagens que demandam nossas tradições mais longínquas, aprofundando e dando densidade às diferenças contemporâneas para as quais concorre tradições literárias, religiosas, filosóficas e científicas que negam o sincretismo entre diferentes povos e crenças. Mas essas diferenças ficam evidentes quando sua literatura aponta para a ancestralidade dos costumes e das práticas cotidianas, martelando, de modo ensurdecedor, a convivência entre Ocidente e Oriente, entre razão e paixão, entre ordem e desordem, em um movimento tão exaustivo quanto compulsivo, capaz de causar a exasperação e o paroxismo.

Se "a queda de Adão se repete na queda dos anjos maus" (DURAND, 2012, p. 114) este anjo caído, de Raduan, é o mediador André, é a criança nas suas andanças, é a rejeição do marido, é a violência, o niilismo, o obscuro entardecer que traz seus personagens e enredos para descortinar a presença angustiante do tempo, traduzido e vivenciado pelas figuras imorais e excluídas. De um lado, a denúncia de uma ordem totalizante e opressora; de outro, a esperança de equilibração na voz dos excluídos; finalmente, a punhalada do destino, mantendo e enfatizando a danação agonística, entrevendo na deseducação apenas as singelas belezas que o caminho da escrita e da vida comum são capazes de oferecer.

\subsection{DESNUDAMENTO}

O conto "Aí pelas três da tarde" (TT) foi dedicado ao amigo, companheiro de escrita e de jornalismo, José Carlos Abbate. Escrito e publicado no contexto do Jornal do Bairro, o conto prescreve e descreve - em terceira pessoa e no modo imperativo - como pode um homem se despedir do mundo da fabricação de verdades e adentrar ao mistério do cotidiano. A indicação de um caminho é intensa a ponto de atestar, sem desvios, mas com tranquilidade, a desimportância do mundo, das coisas e até mesmo de si próprio, confirmando a leitura de Perrone-Moisés (1996), de que a literatura nassariana é uma potente recusa.

$\mathrm{Na}$ descrição, tomado por uma epifania risonha e sinistra, o narrador-jornalista deixa a redação. As três da tarde é um momento de espera. Diante do furor da produção já se prevê o 
crepúsculo. O homem antecipa-se, ao ir embora tomado por um transe. Esse devaneio - presente em outros textos de Raduan - é o lapso pelo qual transita razão e irracionalidade. Nesses momentos de fuga, ficam suspensos os valores, emergindo um tempo supramoral, tomado pelo prazer e pela tranquilidade do desinvestimento.

Ao evocar o "homem moderno", Raduan insinua que o progresso e os valores da modernidade são a outra face de uma remota exclusão: marginalização do delírio e exclusão da passionalidade. O "cansaço milenar" aponta que a utopia da sociedade perfeita é, desde sempre, improvável, trabalhosa e tediosa. Despedir-se do trabalho é também despedir-se da vida, adentrar no âmago de uma pulsão de morte, se isolar da claridade de soluções diurnas e civilizatórias. A personagem deixa a volúpia da sociedade da informação e segue em direção à intimidade do quarto, em direção ao inconsciente e ao esquecimento.

Apelando para uma verdade provisória, "tirando a roupa como se retirasse a importância das coisas" (NASSAR, 2016, p. 348; TT), antevê “o corpo antes da roupa” (p. 236; CC). O processo de desnudamento assinala a deseducação dos textos nassarianos: apesar da máscara cotidiana, toda trama de intenções, inveja, pulsão sexual e vontade de potência regula, também, as relações humanas e sociais. A roupa é a couraça, a razão, entre o inevitável teatro da moral e o ímpeto do desejo. Os comentários da família e dos empregados nos remetem ao burburinho da prática alcoviteira da cidade pequena, como em "Menina a caminho" e "O velho". Há um liame social previsível: tudo que sai fora desta régua é motivo de comentários.

$\mathrm{Na}$ descrição, alheio ao mundo e à ordem, o homem se instala na intimidade: "se achegue depois, com cuidado e ternura, junto à rede languidamente envergada entre plantas lá no terraço. Largue-se nela como quem se larga na vida, e vá fundo nesse mergulho" (NASSAR, 2016, p. 349; TT). O simbolismo vegetal integra a intimidade e os ciclos. De um lado, a intimidade do bosque e do jardim, de outro, a duração do tempo agrícola, em ciclos, que se substancia no prazer da personagem: "goze a fantasia de se sentir embalado pelo mundo" (p. 349). O movimento da rede, que engole o homem, é ao mesmo tempo mansidão e devir, é o sonho e o inconsciente, que movem o mundo sem a necessidade do esforço solar do trabalho.

Segundo Durand (2012, p. 296), “o simbolismo vegetal contamina toda a meditação sobre a duração e o envelhecimento". Nesse caso, o sujeito que envelhece vai se desvencilhando da ambição combativa da juventude e se desligando da pertença ao epíteto de "homem moderno". O homem que vai se tornando maduro e, de algum modo, encontra sua ancestralidade. $\mathrm{O}$ encontro com a ancestralidade é que imprime o "cansaço milenar" pois recupera uma anterioridade jamais alcançada, mas contraposta ao tempo presente. Assim, Raduan assume, desde já, a desimportância do mundo. 
Com Ricoeur, a máscara da realidade esconde a danação humana, matizada na dialogia tarefa-fracasso: "o penitente fervoroso atribui a si mesmo a tarefa infinita de satisfazer todas as prescrições da lei, o fracasso dessa tentativa desencadeia o sentimento de culpabilidade" (RICOEUR, 2015, p. 162). Assim, ao recusar o mundo, a personagem liberta-se, exclusivamente no âmbito do texto, de uma tarefa de reparação e religação fadada ao fracasso constante. Nesse caso, a lei seria a enunciação de verdades, a partir de certo bom senso, apontando soluções para os problemas contemporâneos.

Raduan funde a esperança da graça teológica com a esperança da razão redentora, o que no campo simbólico amplia e potencializa o imaginário da queda, alternando gradativamente a manifestação de diferentes características do comportamento desviante. A sexualidade carnal é o lado oculto do ascetismo religioso, assim como a irracionalidade e a cólera são a outra face da razão. O niilismo é uma atitude possível diante do confronto com o fracasso do projeto civilizatório redentor, seja na chave de uma exegese judaico-cristã, seja na especulação de um suposto fim da história. Por um lado, o niilismo é recusa e reclusão; por outro, é a admissão do jogo e da performance ${ }^{30}$. De um modo ou de outro, Raduan aponta para esse niilismo de fracasso dos projetos, cujo fim das metanarrativas (LYOTARD, 2009) materializa o movimento, no âmbito do percurso histórico contemporâneo. Sua literatura exemplifica na crise moral a impossibilidade de conciliação harmoniosa e mesmo de progresso.

"Mãozinhas de seda", dedicado a Octávio Ianni, intercepta o caminho de "Aí pelas três da tarde" com o sujeito refletindo sobre a passagem da juventude para a maturidade como passagem da verdade para a sofística. O abandono da verdade, assumido pelo sujeito maduro, o reconduz à ancestralidade, manifesta pela figura do bisavô. Quem se encanta e se diverte no jogo diplomático já retirou, de certa forma, a importância das coisas, como em "TT" se tira a roupa. Em outra direção, o Hermes diplomata de "MS" será o Hermes endiabrado de Um copo de cólera e Lavoura arcaica, jogando com os sentimentos e as esperanças mais íntimas do humano. A auto implosão do sujeito escancara as fragilidades e as vicissitudes do contrato social e da comunicabilidade. Ao lado de certo riso, Raduan dá movimento a seus títeres numa espécie de catarse recursiva.

$\mathrm{O}$ riso de "MS" é também a manifestação do arbítrio do próprio saber e crítica à possibilidade de conhecimento e de verdade única. Como comentou Raduan, “críticos e

\footnotetext{
${ }^{30} \mathrm{O}$ niilismo pode ser definido como "a negação de todos os valores. Nada vale nada. Tudo se reduz à ausência de sentido, à ausência de finalidade. As antigas crenças desaparecem e nenhuma outra vem ocupar seu lugar. O homem se vê perdido em relação ao mundo. A raiz latina do niilismo é etimologicamente esclarecedora: nihil, nada" (ALMEIDA, 2015b, p. 77). O termo surgiu no século XIX; na literatura, em Dostoievski e Ivan Turgueniev (Pais e filhos), e na filosofia, em Nietzsche.
} 
escritores, não passamos todos de uns impostores" (NASSAR, 1992, p. 4). De um lado, a convicção da juventude: "a maior aventura humana é dizer o que se pensa" (NASSAR, p. 353; MS). De outro, a máxima do bisavô: "a diplomacia é a ciência dos sábios" (p. 353). O bisavô é a mesma figura do avô de $L A$, tanto que é descrito da mesma maneira ${ }^{31}$. Em $L A$, a figura do avô remete à domesticação do devir, ao domínio do tempo e da morte, substanciando o tempo cíclico. O (bis)avô é o paradoxo na entidade ancestral: "apesar da postura solene [...] era chegado numa gíria" (MS, NASSAR, p. 354). Se em LA é a face terrível do avô que aparece, aqui, em "MS" é a glosa e o riso que sobressaem. Na sequência do conto, o narrador nos leva à cidade de Pindorama. Em setembro, a expectativa se debruçava sobre o baile de primavera. As moças se preparavam para o baile com seus vestidos e a pedra-pomes:

uma pedra cinza e porosa, vendida em tamanho pouco maior que um ovo de galinha, embora amorfa, que elas então friccionavam na palma das mãos para eliminar as calosidades. E se aplicavam no trato da própria pele de tal modo que seus eventuais parceiros, durante o baile, tivessem a sensação de tomar entre suas mãos de príncipes encantados verdadeiras mãozinhas de seda de suas donzelas (NASSAR, 2016, p. 356; MS).

Em Pindorama os rapazes alimentavam fantasias do corpo feminino com o simples toque em suas mãos. O cômico paradoxo que Raduan mostra, entre a ingenuidade de moços e moças e um intenso erotismo subjacente, para o autor, se perde em tempos liberais. Nassar supõe - utilizando a metáfora com ironia - que os intelectuais, "homens barbados", fazem intenso uso da pedra-pomes. A clara dissimulação dos intelectuais dissipa o paradoxo entre os rostos abertos e singelos e as partes pudentas das donzelas. A pedra-pomes teria se transmutado em "pedra angular do mercado de ideias" (NASSAR, 2016, p. 357; MS). Ou seja, tirou o mistério e colocou a dissimulação escancarada.

No conto, a menção a Schopenhauer, por um lado, sugere que Raduan ri de si próprio, pois, como observou Carmona (2011), o pensador influenciou significativamente a produção nassariana. Por outro lado, ao citar o apreço aos negociantes pelo filósofo, também filho de comerciante, Nassar insiste em sua visão pessimista. Para Nassar, certos discursos humanistas usam a ética demagogicamente, como fachada para poder e dominação, como também se vê no ensaio "A corrente do esforço humano" e em Um copo de cólera. Tratados como impostores, esses personagens exemplificam a devassidão das relações morais. Portanto, o apelo aos valores

\footnotetext{
${ }^{31}$ Em "MS": "não dispensava o colete, a corrente do relógio de bolso desenhando no peito escuro um brilhante e enorme anzol de ouro" (p. 353). Em LA: "era ele sempre apertado num colete, a corrente do relógio de bolso desenhando no peito escuro um brilhante e enorme anzol de ouro" (p. 48). O trecho é idêntico, como se vê. Além disso, a caracterização é a mesma: botinas de pelica, jasmim na lapela.
} 
e à ética seria um subterfúgio sofístico para governar as massas. "Mãozinhas de seda" é mais do que "um conto de denúncia contra os vícios da crítica literária" (COIMBRA, 2011, p. 49). Assim como "Aí pelas três da tarde", relativiza e desconstrói a racionalidade humana.

\subsection{IMITAÇÃO E VALORIZAÇÃO PRÓPRIA}

No ensaio "A corrente do esforço humano" (Nachahmung und Eigenwert), publicado na Alemanha, em 1987, Nassar destaca a inferiorização dos países sul-americanos, especialmente o Brasil, em relação a Europa e outros países desenvolvidos. O ensaio começa com um episódio na epígrafe em que Raduan foi convidado para comer rabada à moda da casa em um restaurante no Rio de Janeiro. O amigo de Raduan fora acompanhado de um editor carioca especializado em publicações científicas. $\mathrm{O}$ editor (doente e desenganado) reclamava lamuriosamente das condições médico-cirúrgicas brasileiras, que logo se estendeu aos próprios brasileiros. Ao que Raduan arriscou explicações de fundo sociológico e econômico, fazendo uso da palavra "nós" para qualificar a comunidade brasileira, o editor interrompe com vigor: “Nós, não. Eu sou europeu!” (NASSAR, 2016, p. 402; CEH).

Retomando sua infância em Pindorama (década de 1940) e a supervalorização de produtos internacionais, Raduan inicia o texto descrevendo o complexo de inferioridade brasileiro diante dos países desenvolvidos que se fundamenta historicamente. Isso fica patente quando destaca o "grande desrespeito por nós mesmos" (NASSAR, 2016, p. 404; CEH). Reiterávamos mitificações criadas pela intelectualidade europeia: "éramos um povo indolente, lasso de costumes, de pouca inventividade, e outras pechas que maliciosamente nos atribuíram e que aceitávamos em decorrência de uma mitologia racial e de uma mitologia dos trópicos” (p. 404). Raduan atribui à colonização, à catequese e à mediação da elite brasileira esse sentimento de inferioridade. Relativiza a noção de progresso e demonstra que a Europa seguia sendo um referencial para qualificar o "atraso" brasileiro.

Nassar aponta que as atitudes brasileiras estavam mudando ao longo daquelas quatro décadas. Indica que o preconceito com um país tropical já não era levado a sério, assinalando, com isso, a civilização egípcia, que além de tropical não era branca. Sobre esse tema, Raduan ressalta, em entrevista, que "as etnias puras são tão híbridas como certas espigas de milho" (NASSAR, 1998), expressão extraída do próprio ensaio (p. 407). As etnias europeias seriam historicamente híbridas, como espigas de milho. Acrescenta que os povos nórdicos, que gozam de sucesso contemporâneo, por outro lado, na Idade Média "eram povos que estavam se iniciando na história dos vencedores" (NASSAR, p. 408; CEH). 
Raduan indica que os critérios de avaliação estavam mudando, o que passava a contradizer cada vez mais a tese da suposta inferioridade cultural e humana. Na sequência, o autor mostra como as "grandes civilizações", na verdade, se comportaram sempre como grandes dominadores no decorrer da história ocidental. A "tarefa histórica" europeia, levada a cabo à custa de sangue, morte, ferro e fogo, foi se justificando, em certa tradição intelectual europeia, como "tarefa civilizatória" ${ }^{32}$. Em uma atitude pós colonialista ${ }^{33}$, Raduan fala em "absorção do que interessaria à suposta comunidade brasileira e a que tem legitimamente 'direito', seja à reflexão, à pesquisa, ou às conquistas técnicas [...] realizadas na Europa" (NASSAR, 2016, p. 413; CEH). Nesse caso, ao Brasil caberia se apropriar do conhecimento historicamente construído, mesmo aqueles provenientes da intelectualidade europeia. Raduan mostra a ambivalência e a diversidade do pensamento europeu; por um lado, correntes que exotizam e inferiorizam povos de origem não europeia (os colonizados), por outro, outras correntes criticam a reapresentação de diversos temas e questões relativas à História ocidental. Ao absorvermos ideias europeias nos fiamos, principalmente, no caráter universal do pensamento:

descartáveis ou não, as ideias são universais, no sentido de que sua produção dependeu da "periferia", dos "pequenos", de onde o acervo cultural, pelo menos, não ser patrimônio só da "matriz", dos "grandes", pertencendo antes à corrente do esforço humano, marcado por tantos erros e alguns acertos, sempre comovente quando percebido no seu conjunto (NASSAR, 2016, p. 413; CEH, grifo nosso).

Percebe-se a comovente realização do ser humano, o intenso e complexo legado cultural e a intricada teia de relações entre os povos e suas histórias. Esse exercício de liberdade, no âmbito do texto, marca a literatura nassariana: apropriar-se de um repertório mítico, psicanalítico, filosófico e literário, condensando o problema do autoconhecimento, algo que transcende culturas isoladas e retoma a efemeridade do ser humano. Em outra ocasião, demonstra e desenvolve esse pensamento de caráter histórico e cultural: “a produção das ideias em geral é uma corrente de heranças, aí compreendidos o acervo das nossas liberdades e prisões.

\footnotetext{
${ }^{32}$ Saliente-se $O$ Brasil de Montaigne, de Frank Lestringant (2006), que discute e compara o ímpeto colonizador do período renascentista com o processo de incorporação cultural ocorrido com alguns povos da Antiguidade, notadamente, no contexto da cultura helênica. Trazendo a diversidade em Montaigne, o ensaio pensa na miscelânea cultural, sem o aniquilamento da cultura do estrangeiro.

${ }^{33} \mathrm{O}$ pós-colonialismo é um movimento de relativização cultural da história dos vencedores, sobretudo no que se refere a um esforço de povos colonizados de contarem novamente histórias de dominação dando o devido tratamento às dinâmicas e complexidades da história cultural e política do Ocidente. Lúcio Menezes Ferreira, ao tratar do entrecruzamento entre culturas, adverte: "os encontros culturais [...] as traduções entre culturas, não envolvem apenas um "Eu" soberano que fala de um "Tu" subalterno. Resultam da ambivalência dos jogos culturais, do caráter provisório e posicional das identidades culturais" (FERREIRA, 2008, p. 55).
} 
Patrimônio que não é de nenhum povo em particular, uma corrente que liga civilizações antigas às que virão, passando pelos nossos dias" (NASSAR, 1998, p. 6).

Raduan ressalta a importância de uma triagem de pensamento que convém à manifestação desta identidade dos "vencidos". Ao final do ensaio, faz críticas aos governos militares e seu afã desenvolvimentista hibridizado no paradoxo entre um nacionalismo tosco e ufanista e a cessão de espaço para o capital estrangeiro. Entretanto, ao citar países vizinhos e a descolonização mental no plano artístico e cultural, retoma a danação cíclica: supõe que essas atividades de busca da identidade, sobretudo no campo artístico e intelectual, tenderiam a expressar novamente, no futuro, as relações de dominação sofridas pelos povos colonizados.

Nassar não crê que se possa escapar às relações de poder e opressão pois toda ordem é enunciada a partir de valores. Essa perspectiva retira do horizonte a transmutação como superação dos valores falidos e conduz a uma agonística moral. Isso posto, podemos pensar que não há fundamentação metafísica para uma ética asséptica. A vontade de potência descaracteriza a possibilidade da educação pensada de modo progressista, já que esta pressupõe o crescimento do ser humano, geração a geração, buscando resolver seus problemas adotando posturas melhores.

Como adverte José Mário Pires Azanha, “pense-se, como exemplo de pressuposição absoluta, na impossibilidade de aperfeiçoamento humano. A rejeição desta ideia inviabilizaria a ação educativa. A crença nela, a sua admissão, é algo absolutamente inevitável ao educador" (AZANHA, 1987, p. 71). Raduan Nassar insiste na mensagem de que a espécie não pode se aperfeiçoar. Por isso, entendemos que a deseducação nassariana é radical na recusa da possibilidade de progresso moral.

Em entrevista a Elvis Cesar Bonassa, em 1995, afirma: “eu não aposto no aprimoramento da espécie [...] Isso talvez tenha até haver com meu desinteresse pela literatura em geral. E aí talvez minha náusea em torno de toda produção cultural, porque eu não aposto muito nisso, se o objetivo é achar que a espécie vai melhorar com isso" (NASSAR, 1995, p. 5). No ano seguinte, falando aos Cadernos de Literatura Brasileira, insiste: "este planeta estava destinado desde sempre a ser a caca do Universo. Não deu outra [...] só desequilibrados é que descobrem que este mundo não tem importância. O bom senso seria uma prisão" (NASSAR, 1996, p. 27). A desimportância do mundo e das coisas permite à deseducação nassariana sua projeção apenas como liberdade do texto, abandonando, de maneira radical e serena, o bom senso que aprisiona, as verdades feitas.

Ao insistir na mensagem de que o homem é uma obra acabada, Raduan recorre ao homem caído, entregue a seus jogos de poder expressos nos valores em conflito, substanciados 
na ambiguidade entre o interdito (moral; regras sociais e grupais) e a transgressão (ética de transmutação valorativa, seja de caráter ontológico, espiritual, político ou social): "nenhum grupo, familiar ou social, se organiza sem valores; como de resto, não há valores que não gerem excluídos. Na brecha larga desse desajuste é que o capeta deita e rola" (NASSAR, 1996, p. 29). Em outra ocasião, Nassar discorre: "a espécie é insegura, cheia de medos, angústias, ao mesmo tempo com uma vontade de poder assustadora. Talvez por isso certos grupos acabam por agarrar-se a convicções como superioridade racial, sobretudo quando se encontram em situação melhor que a de outros grupos" (NASSAR, 1998, p. 5). O homem caído de Raduan remete a Schopenhauer, para quem a única forma de ética e aproximação a Deus seria a supressão da vontade.

\begin{abstract}
Que ao homem enquanto tal só sejam possíveis ações pecadoras, isto é, egoístas; que todas as ações morais de autoabnegação só sejam produzidas por Deus, é indubitavelmente a intuição fundamental dos escritos sagrados [...] o homem, enquanto coisa em si mesma, é que dá ao homem, enquanto fenômeno, o imperativo categórico, a lei moral. Esta é a culminação da filosofia kantiana, assim como da schopenhaueriana, a saber, na medida em que nossa essência não está limitada neste invólucro de carne e sangue; na medida em que nós, embora como fenômenos sejamos subordinados ao espaço, portanto, egoístas; ao tempo, portanto, mortais; e à causalidade, portanto, não livres (unfrei) - todo nosso fenômeno empírico é apenas uma aberração (eine Abirrung) de nossa essência em si mesma (von unserem an sich seienden Wesen) (DEUSSEN, 2013, p. 137).
\end{abstract}

Em Nassar, as figuras demoníacas, a sexualidade, a volúpia feminina, a conflitualidade, a violência, a vontade, remetem ao sujeito agônico: "a barbárie corre solta no mundo e a piração é geral" (NASSAR, 1999, p. 12). Essa condição, diante da danação, é expressa com a virulência de quem quer desmantelar todos os ídolos tais como a ciência, a ética, a política, a religião, restando apenas a própria liberdade estética e performática do texto - incluindo arestas e rebarbas - como realização errante.

A materialização do poder em atos interditados pelo regramento social leva à culpa, que leva ao remorso e à (auto) humilhação; esta gera sofrimento e ódio. O ódio retoma o ciclo vicioso da danação anunciada no pecado original ${ }^{34}$. Nesse caso, uma das mais importantes realizações da deseducação nassariana é a superação da cisão bem/mal em função da assunção de uma postura supramoral e extemporânea, revalorizando a simplicidade, o cotidiano comum

\footnotetext{
${ }^{34}$ Ricoeur adverte: "se a falta (o erro) faz o homem culpado, o sofrimento o faz vítima: o que reclama a lamentação" (RICOEUR, 1988, p. 24). Essa convivência entre a posição de vítima e a posição de algoz perfaz o ciclo recursivo: "o homem se sente vítima ao mesmo tempo em que ele é culpado [...] se a punição é um sofrimento reputado e merecido, quem sabe se todo sofrimento não é de um modo ou de outro a punição de uma falta pessoal ou coletiva conhecida ou desconhecida? [...] Tal é o fundo tenebroso, nunca completamente desmistificado, que faz do mal um único enigma" (p. 25-26).
} 
e a dimensão estética da vida, elementos que advém positivamente a partir dos escombros de sua demolição de valores.

\subsection{HUMANISSIMUS HUMANUS}

Neste tópico articularemos tematicamente os três textos estudados neste capítulo, de modo que a circulação simbólica traga maior densidade e detalhamento para apresentarmos o imaginário da queda e para configurarmos o processo de deseducação pretendido.

\subsubsection{Binário}

A expressão "binário" agrupa-se aos termos "dicotômico", "dualista", "dialético", em uma sinonímia que remete à polarização. Binário é também o nome que se dá ao sistema de numeração sob o qual funcionam os computadores. Os textos de Raduan desconstroem tanto o pensamento binário, quanto a primazia da modernidade ${ }^{35}$. O pensamento binário é destituído por Nassar com a apresentação de forças bem visíveis, caricaturas, que se confrontam, trazendo à tona suas contradições e equivalências. A primazia da modernidade é desconstruída pela relativização do progresso e pela recusa das técnicas e da ciência como meios assépticos para sustentar a coesão social. A modernidade é apresentada como uma caricatura que minimiza e esconde as contradições e a corporeidade do ser humano. Sob seu manto toda a sorte de totalitarismos emerge como maquinaria de poder e dominação.

Em "Aí pelas três da tarde" a caricatura binária aparece entre "o bom senso do mundo" e as "ideias claras", cuja repercussão permitiria ao leitor dos jornais, homem comum, emancipar-se de sua condição provinciana, a fim de se alinhar ao que há de mais válido no progresso e na modernidade. O dualismo tosco entre claro e escuro é dispersado por Raduan à medida que vai apresentando ambiguidades e contradições: as ideias se apresentam como luminosas e limpas, mas são extraídas de um ambiente composto por "ruído" e "mormaço". Os sons e sensações que advém destas palavras nos lembram que por detrás dos textos de jornais há pessoas, com suas histórias pessoais e com seus corpos, que não estão separados de suas mentes, colocando em cena as emoções, paixões e sensações enquanto constroem suas ideias.

\footnotetext{
${ }^{35}$ Considerando a transmutação do biográfico em literário, na obra de Raduan, recuperamos a avaliação do amigo José Carlos Abbate sobre o escritor: "eu o enxergava como uma criatura atormentada, cindida: um extremo racionalismo, cientificismo quase, se debatendo com o espiritualismo, fortemente carregado de emoção. Só quando quebrou esse conflito é que mergulhou na narrativa que vinha ensaiando e explorou o que melhor veio dele" (NASSAR, 1996, p. 17).
} 
Reiterando essa leitura, Nassar afirma em entrevista: "acho que a imprensa em geral se questiona pouco, se é que se questiona. Quando leio, por exemplo, certos artigos, onde se nota por trás do texto uma postura ética irrepreensível, eu logo penso: puxa! que sujeito asseado! E não dá pra ser asseado num contexto sem asseio, entende?” (NASSAR, 1984, p. 10). Por outro lado, em paralelo a este asseio artificial, Raduan coloca o "homem moderno". O cansaço milenar é, porventura, a recusa em participar da uma racionalidade impermeável sustentada por uma ideia abstrata de verdade. Não é demais ponderar que, embora o narrador, em sua descrição, recuse os valores da modernidade e as opiniões a eles vinculadas, se vale de uma prescrição em todo o conto. Nesse caso, ao contestar a prescrição de verdades, prescreve também ele uma outra postura diante delas.

Já em "Mãozinhas de seda" o binarismo se apresenta na oposição entre "dizer o que se pensa" e "fazer média". Tal dualismo sofre um redobramento nas figuras do narrador e de seu bisavô, nas moças de Pindorama frente aos intelectuais e na inocência dos tempos antigos em oposição à lassidão dos tempos atuais. Mas o narrador acaba fundindo a autenticidade da inocência e da paixão com a dissimulação da diplomacia. Por outro lado, a imagem aérea que demanda as "ideias próprias", o sobrevoo da análise em busca de opinião crítica, é contraposto com expressões e ambientes telúricos, que na literatura nassariana se ligam ao corpo. Não só as expressões "plantar" e "semente", como a menção aos "decotes", as "mãos", as "partes pudentas" e ao "rosto" demandam corpos e não ideias. O mesmo vale para a descrição de Pindorama, naquele tempo, como território livre de ideias mirabolantes, ancorando as metáforas telúricas e corporais à simplicidade e ao regozijo estético.

O binarismo em "A corrente do esforço humano" se apresenta no antagonismo entre imitação de valores dominantes dos países desenvolvidos e valorização dos próprios brasileiros, incluindo produção industrial, capacidade política, produção cultural, caráter e originalidade de cada povo. Os dualismos vão sendo paulatinamente quebrados ao longo do ensaio. O principal aspecto binário em "CEH" corresponde ao paralelismo entre a inferioridade na qualidade dos produtos e a inferioridade do povo, que o autor procura quebrar: "bom era o produto importado, bom era o homem estrangeiro (europeu); ruim era o produto nacional, ruim era o próprio brasileiro" (NASSAR, 2016, p. 404; CEH).

Ao longo do texto, Nassar apresenta diversos argumentos para desassociar as duas ideias. $\mathrm{O}$ autor põe em evidência uma engrenagem cultural que conduziu tal associação. Cita a importação e a cópia daquilo que se fazia na Europa, sobretudo na França, no que se refere à produção cultural. Aparece também o cinismo da classe dominante brasileira, que patrocina a favelização e preconceitos, apresentados como características “exóticas. A prevalência das 
mitologias raciais, desenvolvidas e reiteradas pela intelectualidade europeia, remonta à catequização e à formação das elites brasileiras, que mandavam seus filhos para estudar na "metrópole".

\subsubsection{Espiral}

A partir das nuances, fissuras e tessituras de cada imagem, Nassar vai compondo camadas, jogos de sombra e luz, fazendo ver a porosidade de cada constelação de valores, seus fundamentos movediços, suas lacunas, evocando tanto a coincidentia oppositorum quanto o tertium datum (FERREIRA-SANTOS; ALMEIDA, 2012). A convivência dos opostos quebra o antagonismo entre duas forças, que sustenta o pensamento uno de cada um dos lados. Já o terceiro excluído abre uma pletora de saliências e tons que faz da terceira via a manifestação de uma diversidade que não só supera o dualismo como oferece caminhos em direções não lineares.

As polaridades binárias que Raduan põe em cena vão se entrecruzando, sendo recuperadas sob diferentes ângulos, revirados ao avesso, alcançando o estertor. A agonística resultante do embate de forças opostas, ao crescer em intensidade e eloquência, vai cavando mais fundo nas idiossincrasias dos polos, perfazendo um movimento espiralado, que atinge, finalmente, as imagens mais primitivas de valor, recobrando a interioridade e a ancestralidade, de onde entreveem incesto, guerra, ciúmes, brigas, submissão, autoritarismo, tortura, torpor. Este movimento espiralado ganha ênfase nos textos mais longos de Raduan, quando a circularidade das narrativas é quebrada pela fixação de novos ciclos, que interrompem os fluxos contíguos e articulam permanentes ambiguidades e contradições.

Em "A corrente do esforço humano" o movimento espiralado das ideias e imagens interpõe às convicções do autor o poder como cerne da condição humana. As nuances e gradações se multiplicam no texto. Escolas de samba compostas majoritariamente por negros fazem homenagem à aristocracia. Brasileiros brancos sofrem nostalgia de uma origem europeia inexistente. Os livros didáticos omitem a etnia dos egípcios. Europeus, que se julgam puros, também são fruto de miscigenação. A primazia cristã na Europa, cuja origem histórica roça o Oriente Médio. O texto cita a insistência dos historiadores em ver na Idade Média apenas trevas, enquanto a cultura árabe vicejava, cita o apagamento dos povos dominados diante do brilho das "grandes civilizações", a falsa dicotomia entre "países sérios" e "países não sérios", a contradição entre o nacionalismo militarista e sua tendência em privilegiar o capital estrangeiro.

Raduan questiona, veementemente, a dicotomia centro-periferia, associando o pardo Brasil miscigenado à origem plural dos povos europeus, compondo irônicas diferenças entre 
estes povos. Mesmo diante das mudanças apontadas ao longo do texto, Nassar insiste na permanência do complexo de inferioridade, que segue enxergando no "acervo cultural" europeu e em sua "metreirice política, capaz de lhe emprestar uns ares de autonomia e maturidade" (NASSAR, 2016, p. 406; CEH), a referência do "atraso" brasileiro. Raduan questiona a noção de progresso, rompendo também com a tecnocracia: o desenvolvimento tecnológico não é sinônimo de um povo melhor. Citando frase de Drummond - "isso não é civilização, francamente; isso é uma porcaria" - o autor questiona a primazia e a referência da Europa. Nassar acrescenta que "o florescimento cultural de uma nação [...] só acontece com o seu domínio sobre outros povos” (p. 409). Nesse caso, rompe o binarismo porque admite que, para além da dominação, os "grandes povos" têm méritos por "seu próprio esforço". Assinala, enfim, uma mudança de mentalidade, desatrelando a qualidade dos seres humanos à qualidade dos produtos brasileiros: "compreendemos cada vez mais essas diferenças de qualidade, e concluímos cada vez menos nossa suposta inferioridade humana" (p. 409).

A deseducação proposta por Raduan neste ensaio refere-se à descolonização mental, o que implica desatar amarras atreladas aos fundamentos teológicos, literários e, principalmente, científicos da supremacia europeia. Romper com as "teorias raciais que privilegiam o homem branco", com a sociologia alemã, que associou o melhor desenvolvimento às melhores condições geográficas e climáticas do hemisfério norte, com a antropologia social francesa que “explicou a "mentalidade primitiva", com os pensadores liberais que entendiam como falso o liberalismo nas colônias e verdadeiro na Europa, com os psicólogos sociais estadunidenses que concluem que os vietnamitas, "devido à grande densidade demográfica, não valorizam a vida, acham a morte algo banal, e desconhecem a dor por ela causada" (p. 411). Na mesma direção, a deseducação nassariana, neste ensaio, rebenta o "pietismo cristão", o "humanismo renascentista", o Iluminismo e a "racionalidade do capitalismo" (p. 412), questionando e refazendo premissas condizentes com a realidade dos povos colonizados.

Além disso, descolonizar-se mentalmente também implica, em "CEH", não transformar o orgulho nacional em arrogância e imperialismo diante de outros povos, como nossos vizinhos sul-americanos e países africanos. Esta deseducação de questionar e desfazer modelos, apontado suas fissuras e falhas, imprime a este e aos outros trabalhos de Raduan uma potência de reequilibração da vida em outras bases, notadamente naquilo que sobra após a enxurrada de contradições e vícios apontados nas ideias e práticas: a dimensão estética da vida. 


\subsubsection{Queda (I)}

Tanto para desinvestir o dualismo quanto para destronar a modernidade, em "Aí pelas três da tarde", Nassar configura a queda em retirar a importância do mundo. Retirar a importância é, do mesmo modo, se retirar da redação de jornal, é retirar cada peça de roupa. Retirar-se do protagonismo das verdades significa, inclusive, redescobrir o corpo debaixo das vestes, o homem comum debaixo das máscaras da verdade e da modernidade. Nesse caso, a queda se manifesta como um prazeroso e tranquilo mergulho na escuridão. A metáfora nos é visível pelo uso das expressões "banhista incerto", "trampolim", "salto", "largue-se" e "mergulho", que não só deixam evidente o movimento físico de cair, como remetem a um gradativo abandono da racionalidade como valor absoluto.

Além disso, ao trazer a água como lugar de salto ou descida, roça o imaginário noturno das águas calmas (DURAND, 2012). Note-se, ainda, que a queda no abismo é amparada pela gradação das imagens. A imagem abrupta do salto é amenizada em largar-se e, na sequência, atenuada no mergulho, completando um conjunto de imagens que eufemiza a queda em descida. Como mestre, o narrador determina: “desça, sem pressa, degrau por degrau” (NASSAR, 2016, p. 348; TT), antecipando a tranquilidade das águas calmas, isomorfa ao balançar da rede.

O imaginário da queda apresenta-se em "Mãozinhas de seda" de forma bastante sutil. Por um lado, indica o deslocamento do banal para o sensual - as mãos prenunciam vaginas e pênis. Em outra direção, remete a degeneração da pedra-pomes em comércio de prestígio. No primeiro caso, as mãozinhas das donzelas, sua suavidade e brandura, transpunham os rapazes para "fantasias inefáveis" sobre como seriam suas partes íntimas. A riqueza da simbologia permite que avistemos também a contradição entre a doçura das mãozinhas das moças e a eventual cor de suas mucosas, "pretas, roxas, ou de cor ainda a ser declinada" (NASSAR, 2016, p. 356; MS). A menção aos "homens barbados", no entanto, traz a antevisão dos pelos pubianos, de modo que os recursos metafóricos põem em convívio as sublimes e doces mãozinhas e as pudentas vaginas, seios e ânus.

No segundo caso, o imaginário da queda permite ao narrador desprestigiar o mercado de ideias em prol da nostalgia daquelas "fantasias inefáveis", que se tornavam interessantes pelo convívio entre a ingenuidade e a malícia. O binarismo dos intelectuais, "eruditos" e "pretensiosos", confinado no asseio aéreo, é quebrado pela contradição: "apesar de avessos a bailes e afetarem desdém pelas coisas mundanas, o que tenho notado é que alguns deles parecem fazer uso intensivo da pedra-pomes, ainda que pudessem dispensá-la" (NASSAR, 2016, p. 357; MS). O aparente desligamento dos intelectuais às coisas mundanas e práticas da vida também é seu suposto desdém em relação a seus corpos. Porém, sua pretensa isenção é quebrada quando 
se torna evidente o mundanismo do "troca-troca" de prestígio, adulação e demagogia. Toda a carranca de asseio e racionalidade é quebrada à medida que as emoções e sensações concorrem para a formulação de seus juízos de valor. Além do mais, se o troca-troca de Pindorama era "picante e clandestino", o comércio de prestígio é "explícito", perdendo sua condição de mistério.

Se a "harmonia do perfill" dos intelectuais se prolonga na falta de "rosto", de emoção, franqueza e proximidade, quando falam em ética incorrem no mundanismo, desvirtuando sua suposta superioridade racional no movediço terreno dos valores. Nesse caso, tanto a "bravata" (demagogia, dissimulação) quanto a "candura" (componente emocional) incorrem na depreciação da razão em opinião, sustentada por juízos de valor. Assim, a pedra-pomes é uma metáfora da queda dos intelectuais na mesma caldeira dos "impostores", desqualificando seu edifício de ideias. É justamente essa contradição que os torna tão humanos, de onde o narrador extrai sua beleza. Tamanha é a "perfeição" destes seres, que a máxima nietzschiana, "humano, demasiado humano"36, se torna especialmente válida na acepção nassariana "humanissimus humanus", que, ao mesmo tempo, dá maior ênfase à Nietzsche, ri do pessimismo schopenhauriano e, afinal, ri da própria condição humana, tão terrena e mundana: a máscara se torna uma dádiva. Por isso, de tão moralmente pessimista Raduan é esteticamente otimista. Ou seja, se não há critérios e valores efetivos, devemos rir do drama humano e da infeliz tentativa de sermos mais éticos.

Em "A corrente do esforço humano", decorrente da deseducação que o ensaio torna evidente, o imaginário da queda alcança a reprodução do poder, já que os valores seriam para o homem um "estigma", de onde, ao mesmo tempo, se pode "subverter a 'ordem' estabelecida" e reproduzir a estrutura de poder. Nesse caso, não nos bastam todas as mudanças de mentalidade que construímos até agora. As hierarquias e as relações de poder são tão inerentes à condição humana que o autoritarismo e o fascismo nos rondam, seja pela submissão aos países desenvolvidos, pelas assimetrias internas de poder ou pelas investidas em dominar outros povos, situações que extrapolam o social e migram para as relações comunitárias, familiares e pessoais e, finalmente, atingem os conflitos internos de cada sujeito. Dessa forma, os valores e os jogos que deles advém possibilitam, simultaneamente, a aventura e a prisão do ser humano. A lucidez que resta é a recusa em se submeter aos dominantes e aos seus valores. Conforme Dostoievski, "tudo seria permitido" àqueles que não se resignam à condição de dominados. $\mathrm{O}$

\footnotetext{
${ }^{36}$ Expressão referente a uma obra de Nietzsche (2000). Em uma livre interpretação das ideias deste autor, a expressão remeteria ao abandono de concepções a priori do ser humano, criticando o idealismo em suas dimensões ética, política e histórica.
} 
poder, em Raduan Nassar, está no cerne das manifestações humanas, o que se comprova quando o autor aponta as relações de poder como "pecado original", sustentadas em valores cujos fundamentos se perdem em elucubrações metafísicas.

\subsubsection{Vontade}

A vontade aparece nos textos de Nassar trazendo delírio, transe e paixão. As pulsões do corpo, ora reprimidas pelos valores, ganham novos patamares conquanto se mostra quão vã é a tentativa de suprimir os desejos. Os valores que sustentam os grupos sociais também atravessam o superego na tentativa de controlar as manifestações instintivas e as pulsões sexuais. Portanto, o domínio dos excluídos, em Raduan, tanto está atrelado ao nítido desprestígio de certos personagens, como aos sentidos e sentimentos que são reprimidos pela ordem vigente. Nesse caso, a forma mentis é moldada pela forma mundus instituída, de modo que os sujeitos e seus ambientes interagem entre si em circuito recursivo, ora reiterando, ora rechaçando o ordenamento pessoal e social.

Embora as rupturas sejam almejadas e ensaiadas, em plano pessoal e social, elas nunca se concretizam sem, com isso, erigirem novos ordenamentos, traduzindo uma experiência terrena que não se consuma nem na supressão da vontade, nem em sua plena realização, tornando a vida uma sufocante batalha consigo mesmo e com as regras sociais. O clima sufocante das relações intra e interpessoais joga a liberdade a um patamar apenas avistado no dinamismo do próprio movimento, conquanto o titubear cotidiano permite poucas alegrias; o sono, a alimentação, o riso, a leitura, a escrita.

Raduan Nassar, em "Mãozinhas de seda", ostentando o pessimismo e insinuando-se mais negativo do que Schopenhauer, saúda o bisavô diplomático: "foda-se o que a gente pensa" (NASSAR, 2016, p. 359; MS). Para Schopenhauer, como aponta Salviano (2009, p. 115, grifo nosso): "o mundo em si é Vontade, e o fenômeno, o mundo objetivo, real, acessível ao conhecimento, é representação". A vontade seria uma força imanente que quer somente a si mesma, deseja satisfação a despeito de qualquer coisa. Qualquer possibilidade de compreender o mundo ou postulá-lo de uma forma melhor seria vã, pois “o conhecimento é um mero instrumento que a vontade usa para saciar-se" (p. 116). Nesse caso, o niilismo de Raduan tem paralelo com a perspectiva do filósofo, já que para Schopenhauer "a razão e o intelecto são apenas uma fachada para a vontade, a verdadeira essência humana" (p. 116). O "miolo propulsor" (NASSAR, 2016, p. 231; CC) de Raduan seria essa vontade cega, indiferente e egoísta que só quer a si mesmo, um infinito e irrefreável desejo de poder: 
esta Vontade é assim a tão polêmica coisa-em-si kantiana. O mundo numênico, portanto, que escapa às formas da representação, é um ímpeto cego, irracional, sem nenhum objetivo ou finalidade, um puro querer. O mundo da representação nada mais é que a Vontade objetivada, tornada objeto (SALVIANO, 2009, p. 114-115).

Raduan crê na vontade como motor do mundo pois não acredita ser possível a sua supressão. Diante disso, as escolhas oscilariam entre sofrimento e culpa, dissimulação e ironia. Em "Mãozinhas de seda" o narrador opta pela dissimulação: abandonem-se os princípios, quaisquer que sejam, porque o ordenamento dos valores não pode mais que uma ética da ocasião, como propõe Rogério de Almeida (2010), analisando o conto Teoria do Medalhão, de Machado de $\mathrm{Assis}^{37}$. Isto é, reitera-se a moral como convenção social e a performance ética, no seio da intelectualidade, como um jogo discursivo.

Por outro lado, a descrença de Raduan é ambígua. Ao dizer que sente saudades de si próprio, o narrador remete ao tempo em que dizia o que pensava, posto que incorporara em si próprio a figura do bisavô. Ele é, anacronicamente, o que era no passado, já que cultiva nostalgia da postura juvenil, e, sincronicamente, o que o avô era no passado, maneira como vive o presente. A exibição da vontade na linguagem circula entre "dizer o que se pensa" e em "fazer média", jogo recursivo e espiralado entre integridade e dissimulação: "talvez o negócio seja fazer média, o negócio é mesmo fazer média, o verbo passado na régua, o tom no diapasão, num mundanismo com linha ou no silêncio da página" (NASSAR, 2016, p. 359; MS). Os milênios da fala do (bis)avô recomendam a diplomacia (em "MS") e a domesticação do devir (em $L A$ ). Entretanto, a humanidade segue seu ímpeto em reformular continuamente a esperança em novos discursos redentores. A corrente do esforço humano, seu movimento de tentativa e erro, sua aventura e seu aprisionamento, recupera no sapiens a figura moriniana do demens.

\subsubsection{Correntes}

A busca pela redenção, em nível social ou pessoal, é a procura pelo caminho, o autoconhecimento e a valorização própria. À aventura humana - dizer o que se pensa ou fazer média, formar opinião ou se abster de opinar, imitar ou tentar ser original - convém "imaginar caminhos diferentes para as relações entre indivíduos e entre povos" pois "não existe nada mais belo e comovente do que perseguir utopias" (NASSAR, 2016, p. 417; CEH). Mas o que nos comove e apaixona não é apenas nossa capacidade de sonhar, mas o conjunto incompreensível da História humana, nossas realizações, assassínios, glórias, mesquinharias e desilusões:

\footnotetext{
${ }^{37}$ Estevão Azevedo percebe o paralelo: “em ambos os contos o que está em questão é o comércio de prestígio: no do século XIX, o social, enquanto no de Nassar sobressai o comércio de prestígio intelectual, o que se adquire mercado de ideias" (AZEVEDO, 2015, p. 192-193).
} 
Sacanagem, inveja, generosidade, amor, violência, ódio, sensualidade, interesse, mesquinhez, bondade, egoísmo, fé, angústia, medo, ambição, ciúme, prepotência, humilhação, insegurança, mentira e por aí afora, mas sobretudo passionalidade, além do eterno espanto com a existência. É este o patrimônio da espécie. Mas não será surpresa se alguém logo mais, passando por cima disso, pegar um fio elétrico com um plugue em cada ponta, enfiar um plugue no computador e o plugue da outra ponta não sei onde, e sair alardeando por aí que é o dono exclusivo da modernidade (NASSAR, 1996, p. 34).

Essa condição visceral e complexa do humano comparece nos textos de Raduan à maneira dos conflitos morais: a honra de um jovem em uma cidade pequena, o castigo e a angústia infantil, o incesto, a violência de gênero, a repressão sexual. São essas contradições e experiências limítrofes que caracterizam a dimensão demens do ser humano. Dimensão imagética, sensual, emotiva, criativa, desregrada, despropositada, como propõe Edgar Morin:

É um ser duma afetividade intensa e instável, que sorri, ri, chora, um ser ansioso e angustiado, um ser gozador, ébrio, extático, violento, furioso, amante, um ser invadido pelo imaginário, um ser que conhece a morte, mas que não pode acreditar nela, um ser que segrega o mito e a magia, um ser possuído pelos espíritos e pelos deuses, um ser que se alimenta de ilusões e de quimeras, um ser subjetivo cujas relações com o mundo objetivo são sempre incertas, um ser sujeito ao erro e à vagabundagem, um ser lúbrico que produz desordem (MORIN, 1973, p. 110-111).

Tanto em Raduan quanto em Morin o homem traduz-se em um paradigma perdido, uma natureza cindida entre o controle e a desmedida. A caixa de todos os males e idiossincrasias humanas se abre, excluindo-se a esperança do horizonte. Raduan, em algumas ocasiões, chega a afirmar que talvez fosse melhor nem se ter nascido ${ }^{38}$. Entretanto, o pessimismo convive, em Raduan, com o otimismo da performance estética e da vontade de potência. Se o patrimônio da espécie, para Raduan, é a corrente do esforço humano, conquanto se olha com perplexidade a capacidade que temos de construir obras belas quanto obras terríveis, nos resta afirmar cotidianamente essas contradições, buscando, em uma razão menor, a pequena lucidez de se submeter sem se resignar, a ambígua postura de uma dimensão estética da vida, cuja

\footnotetext{
${ }^{38}$ Em entrevista, o escritor discorre sobre os papéis da recusa e da rejeição em suas ideias: "futurismo, cubismo, dadaísmo, surrealismo etc. Confesso que sou o exemplo mais acabado de ignorância de tudo isso, por consciente desinteresse. No bojo desse desinteresse se enunciava qualquer coisa assim: fui posto neste mundo sem ter sido consultado, não esperem que eu vá consultar alguém sobre como fazer, na hora de eu expressar minha rejeição a tudo que está aí. Uma rejeição, aqui entre nós, talvez ingênua, coisas do adolescente que fui" (NASSAR, 1996, p. 32, grifo nosso). Para outras referências sobre o inconveniente de ter nascido consultar Emil Cioran (1998). Rogério de Almeida comenta que "para o filósofo romeno, ao nascermos perdemos o mesmo que perderemos ao morrer: tudo" (ALMEIDA, 2015, p. 67). Em outra direção, Cioran (1990) defende que o Homem caiu no tempo, caiu na história. Insiste, ainda, sobre o risco de o Homem cair $d a$ história, não mais ser um animal histórico, abandonar a preocupação com seu próprio destino.
} 
possibilidade de enxergar beleza no movimento e nos mínimos prazeres se torna o refúgio diante da barbárie.

A postura incrédula que assumimos, mediante o movimento espiralado de nossa antinomia permite vermos as sístoles e diástoles, o crescimento e a dissolução do poder, manifesto no querer sublime e grotesco de dominar e ser dominado. Atulhados de escombros (o que resta de nossos edifícios morais) e soterrados de volúpia (o que constitui nossos corpos desejantes), insistimos na vida social, que se torna, paulatinamente, insustentável. Precisamente por sermos, a contragosto, arrastados pela corrente do esforço humano, nunca estamos isentos de participar desta distração, entendida como vida. Ora dizemos o que pensamos, ora somos diplomáticos, incorrendo em poucos acertos e muitos erros, confirmando este caminho tortuoso.

A intensidade da literatura nassariana advém de uma apaixonada recusa de valores e tradições. Uma recusa que mostra, inclusive, o avesso da própria rebeldia. Nassar deseduca desinvestindo, dispersando e confundindo os valores dominantes e, em resposta, não colocando nada no lugar, restando escombros e restos:

todos os textos de Raduan Nassar se constroem em torno de uma recusa: recusa de obediência, recusa de cumplicidade, recusa de amor [...] o abandono da literatura é, em Raduan Nassar, o desnudamento radical. Esse abandono é o efeito de uma cólera, com tudo o que a cólera implica de expectativas frustradas [...] toda literatura de revolta é necessariamente breve, e desemboca no silêncio ou no escárnio (Rimbaud, Lautréamont). Não se pode levar a sério alguém que continue indefinidamente a bradar contra tudo e todos. No silêncio dos revoltados, continua, entretanto, a ressoar sua alta exigência de justiça e de contento [...] escrever é uma forma de esperança. Os mais revoltados, os mais desesperançados dos escritores, depositam na escrita uma energia vital e um desejo de comunicação que age a contrapelo de suas declarações (PERRONE-MOISÉS, 1996, p. 77).

Sendo assim, não nos apetece imitar aqueles que nos oprimem, mas fazer da recusa nossa valorização própria, de modo que se possa recuperar em si a potência e o riso, consagrando a arte (leitura e escrita) como reduto de vida. Torna-se imprescindível ser embalado pelo ritmo do mundo: para que esta corrente não nos atropele e aprisione definitivamente.

Dentre os ritmos nassarianos, entendemos que os contos analisados neste capítulo dão um panorama das metáforas obsessivas do autor, apresentando as dualidades, a circularidade, o universo dos valores, a sexualidade, o transe e o delírio como temas que emergem da condição demens do humano. Diante do exposto, no próximo capítulo avançaremos para a atmosfera interiorana, trazendo análises dos contos "Menina a caminho", "O velho" e "Monsenhores". 


\section{3 (RE)ENCONTRANDO PINDORAMA}

Figura 3 - O cirquinho é hoje!

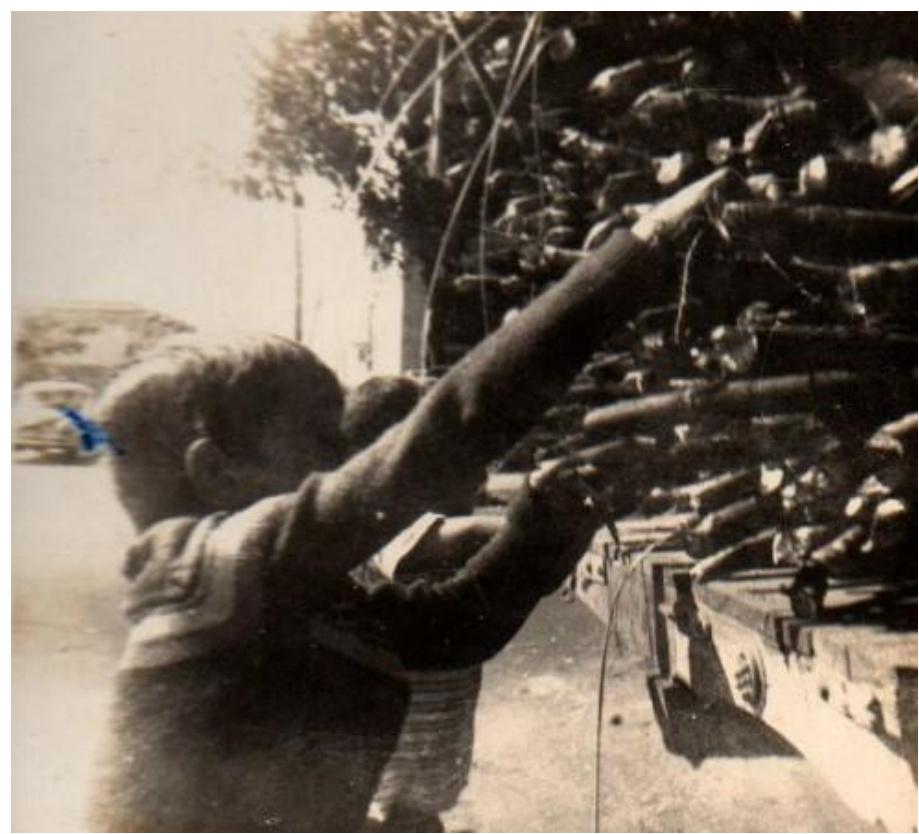

Fonte: arquivo familiar (1969)

Meu tio, Ângelo Cremasco (Bimbo), e seu amigo, Ricardo, roubando cana do caminhão. Naquele tempo a brincadeira carregava na malícia como na inocência, povoando a memória de sortilégios e peripécias infantis.

Figura 4 - Da outra vez teve aquilo

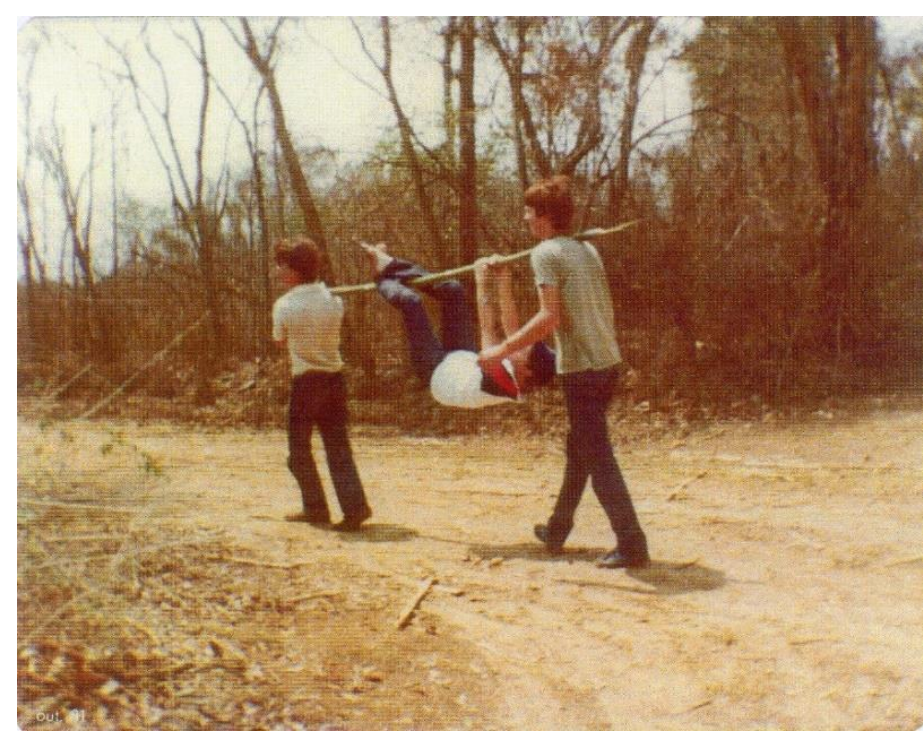

Fonte: arquivo familiar (1981) 
Ângelo Cremasco Neto e Robson Cunha carregam Claudeni Zandona em um pau de arara simulado, replicando latências de todos os gêneros naquele ritual alegórico.

Figura 5 - Um ginasiano pedalando tranquilamente

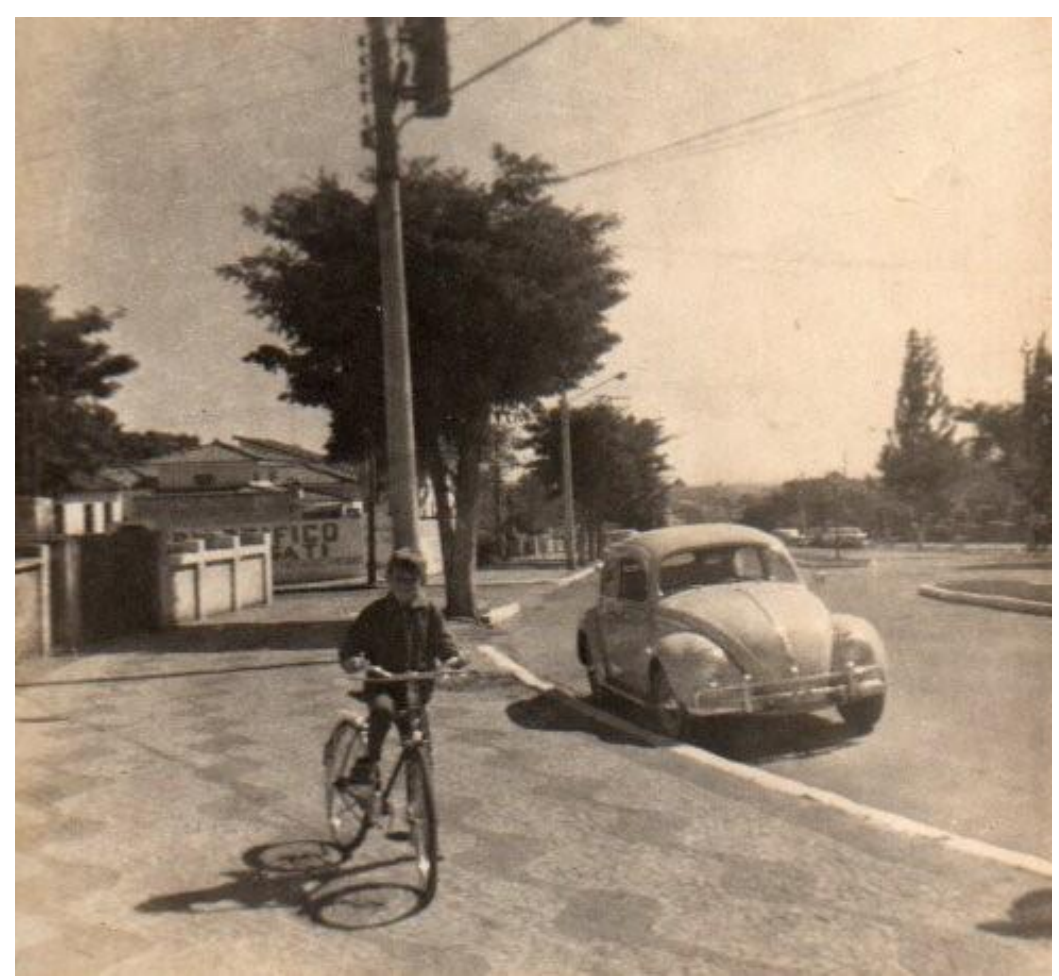

Fonte: arquivo familiar (1969)

O menino Ângelo percorria a cidade às pedaladas, em busca da novidade no ar. O que o vento reservava naquele fim de tarde? O que os "mensageiros mais velozes" da atmosfera carregavam em seu sopro terral?

Este capítulo contempla as análises dos contos "Menina a caminho" (MC), "O velho" (V) e "Monsenhores" (M), textos desenvolvidos sob a atmosfera interiorana. Além disso, dialogamos brevemente com a hipótese um conto nunca escrito pelo autor, "As três batalhas" (TB). Nestas narrativas fica patente a simbologia da mancha e a ruptura da condição idílica da infância e do marasmo provinciano. Em cenários secos, tensos e angustiantes, o leitor percorre cenas de cidadezinhas do interior, recuperando com isso a própria interioridade humana, em sua ambiguidade. 


\subsection{A VIZINHANÇA DE PINDORAMA}

Dedicado à professora ginasial de Raduan Nassar, Laura de Souza Chauí - mãe de Marilena Chauí, "Menina a caminho" possui a mesma atmosfera de "O velho", "Monsenhores" e do conto nunca escrito, "As três batalhas"39 (MASSI, 2015). "MC" foi, declaradamente, inspirado em Pindorama, cidade pequena, próxima de Catanduva e de São José do Rio Preto, há 380 quilômetros de São Paulo: "tem muito da Pindorama da minha memória no Lavoura arcaica e em Menina a caminho" (NASSAR, 1998, p. 5). Hoje, com pouco mais de 15 mil habitantes, na década de 1940 era um lugar onde se radicaram imigrantes de várias origens como muitas cidades do interior do Estado de São Paulo. Religiosa e provinciana, Pindorama fora habitada por sertanejos e índios Caingangue, conforme mostra Masé Lemos (2003), a partir de Pierre Monbeig (1952). A fundação de cidadezinhas naquela região do estado teria se dado por pioneiros interessados em poderio econômico e político.

O conto acompanha as andanças de uma menina em seus desvios, ao levar um recado de sua mãe para o seu Américo. Escrito em terceira pessoa, traz um narrador que assiste às vivências da menina como se estivesse com uma câmera nas mãos. Como adverte Augusto Massi (2015), "Menina a caminho" está para o cinema assim como Um copo de cólera (CC) está para o teatro. No entanto, em poucas passagens, o narrador cede a voz a dúvidas e interjeições da garota, projetando no texto, timidamente, seus sentimentos e sensações. Como quando se questiona no bar da esquina: "o galinho tem uma munhequeira larga de couro preto no pulso direito, pra que será que serve?” (NASSAR, 2016, p. 306; MC). Na oficina: “que cheiro de couro mais gostoso na selaria do seu Tio-Nilo! [...] por que é que falam que o seu Tio-Nilo é um homem perigoso?” (p. 313-314). Além disso, sua voz também é projetada quando imita o bêbado, quando percebe o caixão de criança e quando, finalmente, revela a mensagem ao seu Américo.

A garota sai de casa e anda pela rua observando o movimento da cidade. Trata-se de uma garota pobre e malcuidada. Os primeiros personagens que a menina encontra são três meninos carregando sacos de palha para preparar o cirquinho que acontecerá na casa do Dinho. A menina assiste à disputa: quem empresta fantasia pode levar menos sacos. O Quinzinho, que

\footnotetext{
${ }^{39}$ Em 2017, quando entrevistado pelo Le Monde Diplomatique, Raduan revela a possibilidade de "As Três Batalhas" ser filmado. Ao falar sobre Luiz Fernando Carvalho, Nassar dá pistas: "ele e o Augusto Massi querem filmar a única narrativa que lamento não ter escrito: As três batalhas". Os entrevistadores questionam: "querem filmar sem estar escrita?". Ao que Raduan responde: "desde que eu dê as coordenadas, eles se encarregariam de roteirizar. Na minha opinião, que é bem suspeita, As três batalhas seria uma narrativa razoavelmente boa" (HENRIQUE; NAVARRO, 2017).
} 
emprestará a farda de escoteiro, levou apenas dois sacos. Mesmo assim, diz ao menino que resmunga: "eu acho bom você parar de reclamar" (NASSAR, 2016, p. 288; MC). A menina se encanta com a disputa e tem fantasias com o quintal escuro onde ocorrerá o circo.

Um menino chamado Zuza interpela os garotos projetando sobre eles seu poder. $\mathrm{Na}$ sequência, Zuza é chamado por dona Ismênia, que o interroga maliciosamente. Depressa surge a pergunta: "é verdade que o seu Américo fechou o armazém?” (p. 292). O garoto Zuza, que há pouco encarava os meninos com safadeza, agora sente-se constrangido diante de Ismênia. Seu Américo o tinha dispensado do trabalho pois a cidade toda está falando do seu filho que, na interpretação de Augusto Massi (2015), é homossexual. Não se sabe ao certo qual é a calúnia: o homem diz ao menino que fechou o armazém por causa do calor. Na janela, junto de dona Ismênia, há outra mulher escondida apertando sua coxa e atiçando. $O$ formigamento e a vermelhidão de Zuza indicam seu desconforto. Ele e os três meninos se afastam, mas a menina só se dá por si quando percebe o sexo do cavalo e o jato de urina que respinga nela. Três homens, carregadores descansando, caem na gargalhada e tratam a menina com malícia. Ela, de impulso, sai correndo. No caminho encontra o seu Giovanni que, "nas suas andanças, passa o dia falando sozinho, como se procurasse um menino" (NASSAR, 2016, p. 296; MC). Sabemos tratar-se de uma homenagem a um imigrante italiano de Pindorama:

Esses imigrantes estão nos seus livros?

- De um modo ou de outro, estiveram sempre. Entre italianos, existe uma figura mítica na minha cabeça. Em "Menina a caminho" fiz um registro curtíssimo da sua existência por meio do Giovanni, mesmo assim de modo muito transfigurado. Foi só uma ponta de homenagem, que pretendia ampliar um dia.

- Quem era Giovanni?

- João Baptista Tridda. Mas nem um romance de 500 páginas daria conta do sentido dessa vida. E do drama que foi quando se obrigou, por excesso de escrúpulos, a abandonar a cidade a que ele tinha se dedicado tanto. Entre muitas coisas, fez da molecada uma afinada banda de música. Mas um parente seu por afinidade se envolveu num rombo financeiro, ele não suportou a dor e saiu de Pindorama. Não existem mais homens como Giovanni neste mundo. E era um homem de simples anonimato (NASSAR, 1998, p. 5).

O personagem Giovanni é um andarilho que repete insistentemente “dov'è il bambino?", a procura de uma criança perdida, transfigurando na dor de uma perda traumática e incompreensível os escrúpulos de João Baptista Tridda: "mal se suspeita nele uma vida generosa no passado, pois se deu como poucos ao povoado, desde o começo. Caduco, anda agora perdido na sua cidade, o olhar solto, falando sozinho, como se procurasse um menino" (NASSAR, 2016, p. 316; MC). A imagem da loucura manifesta, aqui, o fracasso do combate moral pelo qual passou este homem. Sua errância cega indica a fuga e uma busca sem direção, 
desorientada. Masé Lemos indica que, em "MC”, “o imigrante é representado como um ser insular habitando uma terra ilegítima, marcada pela violência sob a égide do patriarcalismo" (LEMOS, 2003, p. 102).

O desterro do imigrante marca a perda das referências geográficas, com as quais também se vão as referências morais. Esta desorientação, consequência de dispersões no tempo e no espaço, caracteriza a impossibilidade de retorno às origens, ao tempo idílico, à infância, degenerando a lucidez de alguns: "a loucura [...] aos olhos do Regime Diurno da imagem, colore o inconsciente de um matiz degradado, assimila-o a uma consciência decaída" (DURAND, 2012, p. 94). A menina, circunscrita em sua inocência, assiste em seu caminho a presença insistente de figuras manchadas, marcadas pela decadência, sejam personagens delirantes e alheios, sejam seres violentos, fanáticos e maliciosos. Tal movimento vai, aos poucos, localizando a garota no caráter demens do humano.

$\mathrm{Na}$ barbearia a menina encosta-se na parede de fora para ver o que acontece. Nota os cabelos no chão, o retrato da mulher nua na parede e a moldura de Getúlio Vargas: "a temporalidade se estende, perdendo um registro preciso pelo fato de não ser possível verificar se se trata do tempo do Getúlio ditador ou se o autor alude a uma época posterior, conferindo ao seu conto um aspecto de imutabilidade pesada, claustrofóbica" (LEMOS, 2003, p. 102). O aprisionamento moral sufoca os habitantes da cidade, fazendo do sol e do calor um agravante de uma realidade limitada por um labirinto de julgamentos e violência latente.

No centro de uma roda, na barbearia, um homem gordo fala aos colegas. O sujeito que está sendo barbeado fala repetidamente que o filho do seu Américo merece uma surra. $\mathrm{O}$ homem gordo brada: "na verdade, não tem ninguém, ninguém nesta cidade - ou não importa em que outra cidade - que não seja um filho-da-puta" (NASSAR, 2016, p. 298; MC). O relativismo e o autoflagelo remetem a Schopenhauer: ninguém se salva, todos são egoístas; tudo que fazem é para si próprio e o que ordena a realidade é a vontade má. O barbeiro fica irritado com o discurso e ameaça contar coisas que o seu Américo falou do homem gordo. Fora o homem gordo, profeta da desgraça e do pessimismo, que espalhara a fofoca sobre o filho do seu Américo. O barbeiro insiste: "minha mãe é uma santa!” (p. 300).

Em uma esquina a menina assiste a um bando de garotos que tentam separar um cachorro e uma cadela acasalados com cabos de vassoura. Os animais são finalmente desgrudados quando um dos meninos despeja uma vasilha de água quente. O cachorro some de vista e a cadela fica lambendo seu sexo ferido. A menina transita de cena em cena, retratando os personagens daquela cidade. A cada cena um enquadramento, um conjunto de emoções e sensações provocadas. 
Na sequência, sobe em um muro para ver, através da janela, a aula de dona Eudóxia. As crianças viram as páginas, acompanhando a velha mestre-escola. Um menino interrompe o movimento de virar as páginas e começa a abanar a mão na frente do nariz acompanhado da turma: alguém fez "mau cheiro" (p. 303). Beca, a assistente, procura o responsável, que é, justamente, a menina rica que fizera uma careta para a observadora momentos atrás. A escola aparece como local isolado da fofoca de adultos. É ambiente de vigilância e punição. Por outro lado, o ritmo de virar as páginas, abanar as mãos e apontar o dedo para a menina bisbilhoteira dá uma cadência ao caminho percorrido pelo conto, oscilando entre ingenuidade e malícia, entre integridade e contaminação externa. Sempre que a face terrificante e perversa aparece, a menina sai correndo, como ocorre quando dona Eudóxia a vê bisbilhotando sua escolinha.

A menina some da janela e cai na porta do bar da esquina. Lá o dono e dois sujeitos conversam. Um garoto negro, Isaías, trabalha no bar. É o único a perceber a menina. Mediador, também jovem, partilhará a condição infantil diante daquela conversa de adultos: o mundo infantil e o mundo adulto se relacionam recursivamente neste conto. Três moços entram no bar junto ao Zé das Palhas, sujeito que faz discursos contra Getúlio Vargas, vociferando na direção do rádio, como se pudessem ouvi-lo do outro lado: seu manifesto critica a miséria e a repressão. No entanto, o povo quer ouvir falar do filho do seu Américo. Um sindicalista fortão interrompe: “Getúlio é o nosso pai!” (p. 308). No momento da rixa o galinho mandão se acovarda e foge junto de dois frangotes. O silêncio toma conta do bar. O sindicalista brada contra o Zé das Palhas e vai-se embora.

Momentos à frente, a menina se acha observada pelo Tio-Nilo, de dentro de sua selaria. O macaco, metáfora da imobilidade, segue prisioneiro naquele lugar. O Tio-Nilo aparece como figura íntegra: lança um sorriso franco à menina, deixando-a alegre. Por que justamente o mais íntegro dos personagens é tido como perigoso? A cidade quer contaminar a todos com o fervilhar alcoviteiro, como no conto "O velho", em que o funcionário público, hóspede da pensão dos velhos, é sistematicamente interpelado por grupos locais para ceder à corrupção.

Seguindo o caminho, a garota se depara com um bêbado. Note-se que a menina faz eco ao riso do homem, com um risinho simétrico e menor, como se fosse contaminada pelo que vem de fora, como se fosse, aos poucos, mimetizando aquilo que absorve sem compreender. A sedução é reiterada pela sombrinha azul giratória e rítmica da moça faceira e pelo pano florido da loja de fazendas. A circularidade é reiterada com o ressurgimento do seu Giovanni. A garota desce as mãos (asas), precisamente, diante do cavalo e do camponês, que traz consigo um pequeno caixão branco. A imagem ascensional do anjo cessa com a constatação da mortalidade humana. 
A criança procura a fachada do armazém do seu Américo, com a "águia de asas ainda abertas" (NASSAR, 2016, p. 317; MC). A imponência do armazém do seu Américo contrasta com a vergonha pública causada pelo filho. Os contrastes e os paradoxos se apresentam em um ritmo, tal como o estudante que traça ciclos com a bicicleta, acompanhado de um cachorro, enquanto lê o enorme xingamento na fachada do armazém. $\mathrm{O}$ olhar do menino oscila entre o xingo pichado e a menina, como se entre os dois houvesse uma relação estreita. O adolescente “silabeia várias vezes o xingo a carvão, sem pronunciá-lo" (p. 317). A menina tenta ler os lábios do garoto, que bruscamente vai-se embora sorrindo. O não dito substancia-se, pois, a vergonha moral está alinhada com o mal, com aquilo a que não se pode proferir. A garota, alheia ao mal, está de costas para o xingamento e de frente para o menino, reiterando sua não compreensão da malícia da cidade.

Finalmente, a garota adentra na escuridão do armazém do seu Américo, como se entrasse em um ventre de "silêncio úmido e distenso" (p. 318). O cheiro de peixe reitera a vinculação aos símbolos de intimidade noturna no recolhimento e calma atribuído às mercadorias. A vontade da menina se manifesta pela metáfora alimentar: come as manjubas, lambe o sal, vai comendo torrões de açúcar. Sua voracidade alimentar vem acompanhada de culpa e cautela por ter entrado no comércio do seu Américo na surdina e consumido seus produtos sem ser autorizada.

Visualiza os três santos juninos pendidos nos panos suspensos em um sarrafo; Santo Antônio, São Paulo e São João Batista. O primeiro carrega uma criança nos braços, o segundo tem uma enorme chave do céu na mão direita. Porém, é o terceiro que encanta a menina, com seus cabelos encaracolados segurando um cordeiro com as patas suspensas no ar. A imaginação da menina projeta o pano de São João estendido na quermesse. Entretanto, a graça joanina se ofusca pela escuridão do armazém, "na calma triste de um convento" (p. 320).

O pirulito girando sem cessar reitera o ritmo, enquanto a figura de Getúlio Vargas, novamente presente, garante a imobilidade - a espera de uma autoridade redentora. A menina vai ao encontro da sedução daquele móbile-pirulito e, precisamente, no momento em que cai o seu torrão de açúcar no chão se depara com Américo. A chama da vela que o homem contempla serpenteia com a queda do torrão de açúcar; seu Américo, sentado num caixote, perdido em seus pensamentos, nota a presença da menina. A mancha vai entrando na criança, enquanto a criança entra no armazém escuro: "com a mancha entramos no reino do terror" (RICOEUR, 2015, p. 41). É em temor e tremor que a menina despeja: “minha mãe mandou dizer que o senhor estragou a vida dela, mas que o senhor vai ver agora como é bom ter um filho como o senhor tem, que o senhor vai ver só como é bom ter um filho como esse que o senhor tem" 
(NASSAR, 2016, p. 321; MC). O homem responde: "puxa daqui, puxa daqui, sua cadelinha encardida, já agora senão te enfio essa garrafa com fogo e tudo na bocetinha, e também na puta da tua mãe, e na puta daquela tua mãe" (p. 321).

A menina vai correndo para casa e chega transtornada contando à mãe, aos prantos, o que aconteceu, fazendo seus irmãos menores chorar. Ao ouvir, a mãe começa a quebrar tudo violentamente e grita: "ele me ofendeu mais uma vez, ele me ofendeu mais uma vez, aquele canalha, ele me ofendeu mais uma vez" (p. 322). A fala da menina vem acompanhada das palavras "cachoeira", "molhada" e, sobretudo, do vômito. O jorro discursivo da menina, com o que pode, é marcado pela imagem da água violenta (DURAND, 2012). A força e o susto da palavra da menina se complementam com o violento regurgito. $\mathrm{O}$ vômito também mancha e suja; então, tem-se a riqueza simbólica desta imagem no contexto do conto. Por um lado, a menina bota para fora todo o mal que a manchou, como em um ritual de purificação, mas, por outro lado, os alimentos regurgitados mancham a sala. $\mathrm{O}$ interno e o externo contaminam-se reciprocamente. A mancha vem de fora e facilmente é traduzida em pecado e culpabilidade, de dentro.

A vingança é masculina, é o Deus colérico, é o marido Zeca Cigano, que arrasa a todos sem critério: "o interdito antecipa em si mesmo o castigo do sofrimento; e o constrangimento moral do interdito carrega consigo a efígie afetiva da punição" (RICOEUR, 2015, p. 49). O homem vem do quintal de trabalho, empunhando a marreta, simbolicamente, ferramenta de combate, pronto a consumar sua vingança. A mistura da violência colérica com o heroísmo mártir assume a característica do sacrifício; a mulher como bode expiatório, a Gení. A obsessão pela surra, confessada pelo homem na barbearia, se consuma não no filho do seu Américo, mas na mãe da menina-mensageira. A violência recai na mulher como símbolo da imoralidade. A vizinha assiste à troca de insultos: "cadela" de um lado, "corno" do outro. O linguajar marcando, na violência do discurso, as identidades de gênero, da mesma forma que em Um copo de cólera (CC). Entretanto, em $C C$ a mulher se entrega sexualmente após a violência masculina, já aqui a mulher desafia Zeca Cigano, xingando-o. Ambos registros indicam a penalização do feminino como imoral.

O silêncio prenuncia a surra, enchendo de tensão a vizinha idosa que acompanha tudo ancorada à cerca ao lado. O não dito é a violência latente que vai se tornando cada vez mais eminente na gradação espiralada do conto. A tensão culmina no violento ímpeto solar que combate a sexualização feminina, tal como ocorre no desfecho de Lavoura arcaica (LA). A motivação do homem é uma falsa inquisição: “quem é que te ofendeu? [...] quem é que me 
ofendeu?" (NASSAR, 2016, p. 323; MC). A ofensa e a vergonha são, também, o motivador da ira da família ante o epilético André.

A mulher recebe tremulamente as chicotadas, de bruços. Ao xingar o marido de "corno" a mulher é açoitada mais violentamente, até no rosto. A surra termina quando Zeca Cigano vê a boca da mulher sangrando. A senhora idosa que entrara na casa, pedia inutilmente piedade a Zeca Cigano. Agora rezava e chorava com um terço na mão. A cólera da autoridade e a imagem terrífica da punição não cedem à piedade. É somente no autoflagelo da culpabilidade cativa que se pode alcançar a graça, transfigurando a sexualidade em terror e abstendo-se dela. A clemência vem acompanhada de (auto)punição. Após o sacrifício é retomado o silêncio, um silêncio de reinício vicioso e agônico, mesmo ambiente de espera no qual termina o conto " $\mathrm{O}$ velho". A menina vê, então, a figura masculina do pai “de costas, as mãos na mureta, a cabeça tão caída que nem fosse a cabeça de um enforcado" (NASSAR, 2016, p. 325; MC), semelhante à postura de Pedro, ao voltar para casa acompanhado de André, em LA. Além disso, a menina vê a figura feminina da vizinha aplicando compressas no corpo violentado de sua mãe, tal como Pedro aplica compressas no corpo possesso e açoitado de André.

A mulher que entra no quarto e vê o horror do incesto em Monsenhores (M) agora sai do quarto diante do horror do espancamento, como se a desgraça de Luca daquele conto se compensasse na surra de Zeca Cigano em sua mulher. A mulher é Lucila, Ana e a pobre Sandra (do nunca realizado "As três batalhas"), é a face do fruto proibido, do incesto, do desejo, da contaminação sexual, da pulsão de morte. Mas a mulher é também a misericórdia da vizinha idosa e da amiga de "M". A prostituta e a santa. Enquanto isso, trancada no banheiro, trancada em si própria, a menina descobre a sexualidade.

É o espelho que mostra a vergonha, o prazer, o sexo, tal como no mito adâmico. É Narciso que vê a si próprio, a serpente sedutora, é o início da vida matizado pela infecção iniciática: "no limite a criança nasceria impura, contaminada originariamente pelo sêmen paterno, pela impureza da zona genital materna e pela impureza adicional do parto" (RICOEUR, 2015, p. 44-45). A violência do pai simbolizada pelo espelho, a impureza do parto na moldura de santo que enquadra o sujeito desde o nascimento, a fragilidade e o prazer da mãe na carícia da vagina. Os olhos saltam e a menina, enfim, sente malícia ${ }^{40}$.

"O velho", escrito em 1958, tal como "MC" e "M", conserva a atmosfera da cidade pequena. Em Raduan Nassar existe um movimento constante entre o geral e o particular, entre

\footnotetext{
${ }^{40}$ Em Lavoura arcaica (BRA-2001) há uma cena idêntica, na qual a personagem Ana, interpretada por Simone Spoladore, se agacha em um espelho para ver a vagina. No filme, os dedos de Ana com sangue sugerem, então, a primeira menstruação.
} 
o macro e o microcosmo. O homem é microcosmo da humanidade, a cidade é microcosmo do mundo, a família é microcosmo da sociedade. Esse dinamismo cadencia seus textos que adquirem musicalidade:

\footnotetext{
a sonoridade musical é vivenciada como fusão, comunhão do macro e do microcosmo. O simbolismo da melodia é, portanto, como o das cores, o tema de uma regressão às aspirações mais primitivas da psique, mas também o meio de exorcizar e reabilitar por uma espécie de eufemização constante a própria substância do tempo (DURAND, 2012, p. 225).
}

A pequena cidade seria lugar de calma, paz e redenção, mas Raduan frustra esse imaginário. A cidadezinha não é mais que uma miniatura da violência cosmopolita. Os homens e suas paixões cotidianas, unindo e desunindo em uma desarmonia ordenada. Se em "MC" a garota é um centro que se desloca buscando enquadrar os personagens e as cenas, em " $\mathrm{V}$ " $\mathrm{o}$ centro é uma pensão interiorana administrada por um casal de idosos, que hospeda um funcionário público e uma professora.

Em "MC" há uma claridade obscura, como um sol negro. Já em "V" este movimento se amplia e se completa. As trevas, homólogas à imagem terrífica do tempo, chegam inevitavelmente ao final de cada dia: "a claridade na cozinha vai morrendo com a tarde" (NASSAR, 2016, p. 365; V). As trevas vão ganhando o horizonte do mundo e tomando o ser, tal como na simbologia da mancha: "no folclore, a hora do fim do dia [...] deixa numerosas marcas terrificantes [...] as trevas noturnas constituem o primeiro símbolo do tempo" (DURAND, 2012, p. 91). Entretanto, em Nassar, a simbologia da mancha vai se desenhando de maneira bastante sutil, evocando, a partir de descrições simples e diretas, fantasias e símbolos que localizam o medo em seu aspecto moral. Nesse caso, as figuras fantásticas que seriam demandadas em um imaginário solar são omitidas por um vocabulário da intimidade, que traduz no cotidiano a presença de aspectos terrificantes nas atitudes, nos objetos, nos fluídos corporais e nos animais, compondo ambientes em que a ambiguidade e a incerteza imperam, sob a luz opaca do dia a dia.

As trevas, conforme a moralização da noite e do mal, substanciam-se em angústia diante do devir. Incluindo a dimensão sexual implícita no movimento de contaminação e queda, essa angústia expressa-se no pecado e na culpabilidade, o que caracteriza a experiência de linguagem descrita por Paul Ricoeur: "a mancha faz a sua aparição no universo humano por meio da palavra; a sua angústia é comunicada pela palavra: antes de ser comunicada, essa angústia é determinada e definida pela palavra; a oposição do puro e do impuro é dita; e é a palavra que a exprime" (RICOEUR, 2015, p. 52). Ávida de ser derramada, a palavra da confissão é precedida 
de silêncio. É o silêncio sufocante e solitário da culpabilidade que vem dar à palavra sua violência explosiva. Como supõe Georges Bataille (2014), o recuo prepara o salto, a festa, o dispêndio, o elogio da vontade. Esse recuo acumula uma violência latente, matéria fundante da vontade de potência. Durand, citando Bohm (1955), indica que "esse choque diante do negro provoca experimentalmente uma 'angústia em miniatura'. Esta angústia seria psicologicamente baseada no medo infantil do negro, símbolo de um temor fundamental do risco natural, acompanhado de um sentimento de culpabilidade” (DURAND, 2012, p. 91).

O conto "O velho" é conduzido pelo transe rítmico de um idoso dentro de uma pensão interiorana durante o entardecer. $\mathrm{O}$ assunto do fervilhar alcoviteiro desta cidade centra-se no hóspede, um rapaz, coletor de impostos. O velho diz: "não faz nem meio ano que ele chegou aqui e já andam falando dele" (NASSAR, 2016, p. 366; V). Fica patente a rejeição e a impaciência da velha, Nita, ante seu marido. O velho preocupa-se com uma imagem a zelar: "foi lá no bar do Nonato, era só comentário, todo mundo estava falando dele, até caçoaram de mim" (p. 367). O velho citará, ao longo de todo o conto, certas "farras" que acredita não ser costume de seu hóspede. O velho se solidariza com o rapaz como se quisesse acreditar em sua completa inocência: "eu disse que todo mundo estava enganado pelo menos numa coisa, é que ele não queria prejudicar ninguém, eu disse que esse bacharel era só um coletor zeloso e correto" (p. 367).

A imagem do coletor de impostos sempre suscitou aversão do povo, fixando-se, mediante a cultura judaico-cristã, na figura de Mateus. Segundo o velho Eugênio, aquele moço não aceita suborno de modo algum, mas "nunca que vão aceitar isso, um funcionário público que cumpre seus deveres com o estado e com o povo" (p. 368). Nita segue açoitando o velho e pedindo que vá tomar banho. Em resposta, ele resmunga que a mulher nunca o respeitou. $\mathrm{O}$ homem vai ao quarto e cochila, acordando com o céu mais escuro. O velho vislumbra um homem que vasculha o alpendre da pensão. O homem vai ao encontro de um carro preto parado com um motorista e uma loira de vestido vermelho no banco traseiro. Ao sair, a mulher é escondida: deve sair de cena. O idoso, Eugênio, é um espectador-voyeur, como a garota, em "MC". Quando o pensionista chega na casa o velho não tira os olhos do moço.

O isolamento do rapaz chama a atenção do velho: "desde que chegou, seu silêncio impermeável, e a reclusão que se impôs a cada noite, fechando-se na cela do seu quarto" (NASSAR, 2016, p. 372; V). Eugênio observa o moço, obstinadamente, à procura de uma resposta para sua sútil mudança de atitudes. A outra hóspede, professora descrita com ares de bruxa, observa as mãos do outro pensionista. Os olhares inquiridores da cidade e dos residentes da pensão são os mesmos olhares dirigidos ao filho do seu Américo em "MC". O jantar é 
carregado com uma tensão silenciosa. Quando o carro preto freia diante do portão da pensão o medo do moço expressa-se no tremor da colher. Um carro para, deixa alguém que caminha no alpendre e parte numa arrancada. A compressa, presente em $L A$ e "MC", aparece novamente no movimento do guardanapo da professora, associado ao gesto de alimentação. De repente, naquela mesa de jantar silenciosa, o moço irrompe reiterando sua retidão: "reconheço só pelo arranque o carro dos que estão à minha caça, não aceitam que eu contrarie seus interesses [...] Não cedi a eles, quando se apresentavam como amigos, não me vendi depois, quando se dizem realistas, tentam agora me difamar como inimigo. Se não me dobrar a essa chantagem, matam" (NASSAR, 2016, p. 376; V, grifo nosso).

Por conseguinte, o coletor de impostos estava sendo reiteradamente chantageado. Poderosos locais quiseram dissuadi-lo e suborná-lo. Não tendo cedido, passam a ameaçá-lo. A digestão da professora acompanha a tensão da mesa; ela, então, tosse muito ao tentar deglutir os alimentos e se retira. $\mathrm{O}$ senhor Eugênio finalmente encontra a palavra que procurava em silêncio: "raiva". Em sinergia com a angústia do rapaz, o velho quer identificar precisamente o sentimento do pensionista, expressando uma solidariedade não correspondida. $\mathrm{O}$ moço permanece isolado.

Chegando ao alpendre, senhor Eugênio nota o perfume, prenúncio da presença feminina, naquela pensão. A riqueza interpretativa permite que Estevão Azevedo (2016) associe o perfume das flores com um prenúncio de morte, mediante a debilidade do velho. A senilidade de seu Eugênio, além disso, reitera sua decadência, tal como as flores em "Monsenhores" aparecem caídas. De todo modo, tanto a morte quanto a presença feminina, interpretações possíveis, sinalizam o que está oculto nas cenas que se desenvolvem, reforçando o não dito e o silêncio como recursos narrativos e associando a feminilidade e a morte a uma outra face, aquilo que não se quer ver, não se quer mostrar e não se quer reconhecer. É nos quartos dos pensionistas, ao fundo, que ocorre o jogo de luz e sombra, entrevendo o movimento. Sentado na cadeira o velho vê o homem de outrora passar, como quem vigia a casa. O rapaz finalmente cederia aos apelos de seus chantagistas através da mulher enviada para seduzi-lo.

Eugênio, enfim, conhece o fraco do coletor: farras. A sexualidade é o último recurso de seus adversários para persuadi-lo a participar de seus interesses. É notável a promiscuidade entre sexualidade e poder na obra de Raduan, fazendo-se notar em todos os seus textos, desdobrando-se de maneiras diferentes em cada um deles. A mulher puxa o rapaz para dentro do quarto em um movimento característico de engolimento. Segundo Gilbert Durand, o engolimento "transfigura o despedaçamento da voracidade dentária num suave e inofensivo 
sucking" (DURAND, 2012, p. 206). Ou seja, o que aparece no conto como ameaça é eufemizado no sucking sexualizado.

Ao saber da corrupção sexual do moço, a angústia do velho se dissipa como quem resolve o mistério e confirma uma suspeita. Senhor Eugênio não queria acreditar no que já sabia: ninguém é incorruptível. Reitera-se o caráter sexual da corrupção, reenviando ao mito adâmico. Já que o "ventre sexual e ventre digestivo estão [..] em simbiose" (DURAND, 2012, p. 216), imagens digestivas povoam este conto, durante o jantar. O silêncio do conto sugere uma equilibração do imaginário, dissipada a tensão na sensualidade do encontro furtivo aos fundos da casa. Entretanto, "há em tudo um clima silencioso de espera" (NASSAR, 2016, p. 383 ; V), o que sugere que a aparente calmaria harmônica será novamente interrompida pelo ciclo repouso-vontade, silêncio-cólera.

"MC" e "V" são contos iniciáticos. Por isso, mostram a mancha que vai se aproximando sorrateiramente por meio do outro e se instala no sujeito, definitivamente, como malícia. Em "MC" a mancha se instala mediante a violência da surra. Em "V" a infecção ocorre apelando à sensualidade feminina. As trevas que vão se instalando, no primeiro conto, são uma violência que vai crescendo em espiral. No segundo, é a noite que vai tomando a casa (arquétipo da morada) como se tomasse o sujeito incorruptível. O bom funcionário e a menina inocente; nada resiste aos encantos da serpente. Nesse caso, firma-se o caráter sexual da mancha:

\footnotetext{
somos surpreendidos pela importância e gravidade da violação das interdições de caráter sexual na economia da mancha; as proibições do incesto, da sodomia, do aborto, das relações em momentos - e por vezes lugares - interditos é tão fundamental que a inflação sexual é característica do próprio sistema da mancha, a tal ponto que, entre sexualidade e mancha, parece ter-se formado uma cumplicidade indissolúvel em tempos imemoriais (RICOEUR, 2015, p. 44).
}

Tanto "MC" quanto "V" recorrem ao momento primordial no qual se instala a corrupção, em que se cede à tentação. A insistência da característica desviante, que vem de fora, sobre os personagens, nestes contos, retira das figuras puras sua condição de inviolabilidade. $\mathrm{O}$ instante da queda apresenta-se, efetivamente, como violação de um invólucro, como a profanação da experiência idílica da retidão e da harmonia.

\subsection{FÊMEAS MENSTRUADAS}

Dedicado à Augusto Massi, "Monsenhores" (M) é o único texto de Nassar em que há narração feminina do início ao fim. A tímida participação direta do feminino na obra de Raduan 
mostra o seu apagamento diante de questões que foram historicamente entendidas como masculinas. A religião e a política, mas também a ciência e a literatura, atividades intelectuais, são campos em que a primazia do masculino se consolidou, de diferentes maneiras, amparada pelo histórico patriarcal que marca as culturas ocidentais. Se a narração, em terceira pessoa, da jornalista em Um copo de cólera (CC) reproduz o estereótipo da mulher como mãe, a narração em " $\mathrm{M}$ " reafirma esta caricatura introduzindo o recurso narrativo do fluxo de consciência, fundamental para CC e Lavoura arcaica (LA). De um lado, a jornalista fomenta a ambiguidade entre emancipação e submissão, de outro, as mulheres de " $M$ " reiteram a ambivalência entre santidade e promiscuidade. A submissão da narradora de "M", dona Ermínia, reforça a repressão do feminino em "MC", contrastando com a autoridade e austeridade de Nita em "V" e de dona Eudóxia em "MC", ressaltando que a respeitabilidade das mulheres advém na assunção de posturas masculinas.

"M" se inicia in media res, apresentando os pensamentos de uma ex-professora e dona de casa, dona Ermínia, que é chamada a intervir em uma situação-limite de uma família amiga. O tempo desenvolve-se rapidamente, alternando sentimentos e sensações da narradora, com divagações que vão compondo enquanto realiza um caminho de sua casa até a casa do casal Luca e Lucila. A atmosfera interiorana se faz presente na descrição da movimentação das famílias durante o jantar e na menção à “escolinha rural” (p. 391), conquanto o espaço do conto orbita nos mesmos confins de "MC" e "V".

A narrativa começa quando um rapaz vai até a casa de Ermínia levando o recado de Luca, pedindo que a mulher vá urgentemente a sua casa. Ignorando seus próprios filhos, a melhor os deixa a espera e sai correndo pela rua até chegar à porta da casa de Lucila e Luca. $\mathrm{O}$ homem o atende em silêncio e acompanha, com gestos sinistros, até o quarto onde está sua esposa. Os pensamentos de Ermínia apresentam ao leitor suas observações sobre a cena que vai se desenvolvendo. A casa está quieta, em penumbra, as flores (monsenhores) que a amiga tinha pegado anteriormente em sua casa estão murchas na sala. A narradora percebe, ao observar os sapatos nos quartos, que Luca dormia há tempos separado de Lucila, no quarto do filho do casal, Dinho, afilhado de Ermínia.

Afinal, a dona de casa chega ao "quarto deles" (p. 395), como Luca se refere ao aposento em que a mãe dormia com o filho de treze anos: "a cama de casal desarrumada, o lençóis amarfanhado deixando um tanto descoberto o pijama do Dinho" (NASSAR, 2016, p. 396; M). O marido menciona que viajou em um dia e encontrou a cama "deles" revirada na volta. Ermínia encontra Lucila encurralada no canto do quarto, sem sinal de respiração, acocorada, com a saia do vestido vulgarmente levantada, entrevendo em seu ventre o gotejamento de algum fluído 
corporal proveniente de sua vagina. O adolescente de treze anos, Dinho, teve relações sexuais com a própria mãe, sendo levado a um colégio interno, com a descoberta do pai. Embora a atmosfera seja de violação, não é possível afirmar se a relação foi consentida. Também não fica claro qual líquido escorre de Lucila, ainda que a menstruação seja mencionada no desfecho do conto.

O silêncio, o não dito e o segredo são mantidos como metáforas para transgressões da ordem, amalgamadas entre moral e sexualidade. Apenas parte das situações escabrosas são mostradas ao leitor nos contos "M", "V" e "MC", dando força aos vetores ocultos e integrando a simbologia da mancha, que contamina por fora. A metáfora da infecção, em "M", recorre como escuridão: "tive o pressentimento de que a Lucila tinha entrado irremediavelmente num túnel de onde não sairia nunca mais, se entregando a um fim sem volta" (NASSAR, 2016, p. 397; M). O silêncio reaparece à medida que a região limítrofe da moralidade é alcançada pelos personagens, revelando uma atmosfera fúnebre e tensa, dissipando, em parte, a angústia da expectativa, e refazendo uma tranquilidade insustentável e superficial, que marca a aparente harmonia restabelecida mediante o alcance do torpor.

Nesse caso, tanto em "V" como em "M" os gêneros sexuais estão em sinergia, recobrando de modo caricatural o fundamento sexual dos conflitos morais. Eugênio se solidariza com o pensionista. O velho não quer acreditar na culpa do rapaz, mas, paradoxalmente, sua angústia se dissipa quando se comprova, enfim, que o coletor de impostos é corruptível. Em "M", as amigas de Curso Normal, professoras de crianças em formação, partilham a condição de "fêmeas menstruadas" (p. 397). Se Eugênio é submisso a Nita, é indigno, excluído. Estar fora o incomoda, mas acaba se sentindo melhor quando descobre que o rapaz é corruptível, colocando-os na mesma condição de imperfeição. Ermínia, que atende aos apelos de seu marido, Miro, para não pensar muito, compreende no campo emocional sua solidariedade em relação à amiga Lucila: sororidade.

\subsection{INTERIOR}

"Monsenhores" (M), "O velho" (V) e "Menina a caminho" (MC) são contos nos quais se apresenta o interior do São Paulo, as cidadezinhas tão pequenas e tão esquecidas na vastidão geográfica de um Brasil de imigrantes. Nestes contos são vários os traços de forma e conteúdo que convocam o ambiente e os costumes interioranos. Dentre eles, destaca-se a oralidade dos narradores e de alguns personagens em "MC" e "M". Expressões como "pr'um menino de treze anos”, “pr'eu ir”, “c’uma expressão dura e calada”, “c’um safanão no peito”, “c’uma criança 
nos braçoo", “c’uma dor de cabeça eterna”, “co'arrastação das cadeiras”, “partir pr'esse papo", denotam o modo caipira de falar, comendo silabas, de modo arrastado, mas o modo de falar de Minas Gerias também aparece em “qu'é isso, sô?”. Também em Um copo de cólera (CC), no discurso do chacareiro, aparecem expressões como "c'uns ares de heureca" ou "c'uma gana".

Em nosso caminho, sair da volúpia cosmopolita é também sair do ambiente aéreo em que as ideias e a abstração predominam. Avançar de São Paulo em direção à terra roxa é conquistar o espaço corporal de todas as cidades criadas pela violência bandeirante e pelo branqueamento abolicionista. Entre aquelas ruas de terra e as casas de barões e gente simples, um pouco misturadas, um pouco afastadas, prenunciam ferrovias, trens, estações, portos e histórias. Pindorama é, portanto, uma zona indeterminada e fronteiriça, na qual convivem Minas Gerais, São Paulo e várias geografias do Mediterrâneo. Não é difícil imaginar que buscar o interior, a fixidez da terra, é também sair à procura do que há dentro: estamos indo sempre para casa.

A experiência de deseducação possível nestes textos remete à desconstrução das aparências, da inocência e da paz de um lugar idílico, do qual também emergem vergonhosos segredos e atitudes violentas. O êxodo rural brasileiro da segunda metade do século XX possibilita uma terna saudade do ambiente bucólico das cidades interioranas. Seu marasmo provinciano é compensado pela virulenta volúpia de comentários sobre a vida alheia. Das entranhas daquelas estórias comuns proliferam caminhos e estradas que nos ligam aos nossos valores mais longínquos, sobre os quais assentamos as máscaras cotidianas.

\subsubsection{Idílico}

A caracterização da cidade interiorana como lugar idílico investe tanto em memórias e imagens de ingenuidade e inocência quanto na incorporação de tímidos traços fantásticos em "Menina a caminho". A paz do interior se compõe no clima primaveril, nos fins de tarde amenos, e nas paixões que se insinuam no formal Baile de Pindorama. A "perspectiva casadoura" (NASSAR, 2016, p. 356; MS) do evento se manifesta como as "promessas de amor suspensas na pureza de um amor maior" (NASSAR, 2016, p. 31; LA). O trágico e o lírico no amor de Lavoura arcaica são traduzidos no cômico de "Mãozinhas de seda". Entretanto, a intimidade comparece em ambos os textos. A atmosfera familiar, em conforto e segurança, possibilita o flerte com elementos da fantasia. As moças da cidade "se aplicavam no trato da pele de tal modo que seus eventuais parceiros, durante o baile, tivessem a sensação de tomar entre suas mãos de príncipes encantados verdadeiras mãozinhas de seda de suas donzelas" 
(NASSAR, 2016, p. 356; MS). O ambiente pacífico e tranquilo, capaz de emprestar às cidadezinhas um ar lúdico e benfazejo, se conforma sob a atmosfera dos dias primaveris:

\begin{abstract}
Nesses setembros, os dias eram claros, o céu liso, "um céu de vidro" como se dizia, e a temperatura poderia ser considerada amena para a região, apesar de já prenunciar o calorão dos meses seguintes. Era um tempo propício pra tagarelar, principalmente nos finzinhos de tarde, depois da janta, quando as famílias puxavam cadeiras pras calçadas, a que se juntavam vizinhos e amigos. E ficavam rindo gostosamente à toa, jogando conversa fora, assegurando entusiasmo à algazarra das crianças. Eram risos, vozes e pequenos gritos, tudo amortecido pela amplidão do espaço livre, até que "a fresca da noite" e o sono os dispersassem (NASSAR, 2016, p. 355; MS).
\end{abstract}

O imaginário de repouso e intimidade apresentado neste trecho é um dos raros momentos em que o esquecimento toma conta do universo nassariano, fazendo da inocência e da simplicidade realizações para as quais não concorre mais do que o simples fazer e viver. Estes instantes suaves possibilitam que o leitor respire diante da tensão e do sufoco dos conflitos morais. O clima extemporâneo convoca a infância para sua dimensão de eternidade. As imagens da criança e da infância dão potência à literatura de Raduan, embebida nas águas do Divino: “Deus é a criança que está em nós e a epifania dessa infância é um perfume de infância para onde nos reconduz o odor de uma flor seca” (DURAND, 1988, p. 73). A literatura de Nassar, testemunho da humanidade remota que habita todos nós, apela ao mal elementar, maculado em violência, desvio, sensualidade, libertinagem, confusão: "a literatura não é inocente, e, culpada, ela enfim deveria se confessar como tal $[\ldots]$ a literatura $[\ldots]$ é a infância enfim reencontrada" (BATAILLE, 1989, p. 10). Além disso, apesar da lançar suas questões à interioridade e ao imaginário universal, Raduan não deixa de aterrar a dimensão estética da vida nas imediações entre São Paulo e Minas.

Mais à noite, em "Monsenhores", a tranquilidade se reveste na vida familiar: "vindo das casas, a barulheira das famílias na mesa, e podia até dar conta dos risos, a vida na hora do jantar em cada lar como lá em casa" (NASSAR, 2016, p. 388; M). Diante dessas imagens de paz e tranquilidade constelam símbolos de inocência e silêncio. A inocência, a castidade, o recato e a candura convivem e articulam-se entre si como atributos da santidade e do paraíso. Inocentes são os meninos que disputam o prestígio do cirquinho, os alunos que partilham o medo da mestre-escola, a menina que deambula pelas ruas da cidade, o menino Zuza que fica encabulado diante dos gracejos de dona Ismênia, os irmãos da menina que choram ao ver cenas de violência sem compreendê-las.

A castidade e o recato se impõem à organização da festa infantil, na qual não poderá participar quem tem mais de doze anos para preservar a socialização sem sexualidade. Diante da observação de toda essa aparente inocência, sobressaem os cândidos olhos da menina, que 
vê, sem enxergar, toda malícia entreposta em cada uma das situações triviais. O silêncio, por sua vez, não adquire um estatuto de esquecimento e desimportância, mas aparece como uma trégua entre cada um dos arroubos percorridos pelos personagens. Com a suspensão dos conflitos, persiste nestes contos a angústia e a tensão.

A inocência comparece, também, na descrição do pensionista, em "O velho", quando o senhor Eugênio observa "a nuca do bacharel, onde o remoinho dos cabelos, rebelde, guarda um visível frescor infantil, compatível por sinal com suas faces de menino, um tanto imberbes" (NASSAR, 2016, p. 372-373; V). Neste mesmo conto, o senhor Eugênio também é infantilizado por sua esposa, dado que sua atual condição vulnerável permite solidarizar-se com a vulnerabilidade do coletor de impostos. Também infantilizada e diminuída pelo marido, Ermínia, em "Monsenhores", solidariza-se com Lucila na condição de vulnerabilidade da mulher em ambiente patriarcal. A tais vulneráveis, como o são as crianças em "Menina a caminho", é permitida a solidariedade, conquanto seu silêncio é conquistado à medida que sua participação no espaço público e nas decisões é abafada, como são asfixiadas também suas faces ocultas, tornando o silêncio uma recusa violenta em reconhecer o outro. Nesse caso, a inocência e a candura circulam nos textos como expressão de uma cínica presença do que é estranho, do que está fora, do que participa do universo dos excluídos:

Raduan Nassar elevou ao máximo a potência dos seres supostamente pequenos. No universo paternalista, em que a fala alheia está sob as rédeas de fazendeiros megapoderosos, é a voz do adolescente que prevalece; na casa modesta, em que a decisão está a cargo da gente simples e grande, é a ótica da criança que restabelece a harmonia humana possível. Somente uma obra literária desse patamar poderia evidenciar que homens e mulheres alternam afetos e razões, para além do maniqueísmo, da hierarquia e das distinções de classe, corpo, etnia e gênero (CHAUVIN, 2017).

As sutis descrições e narrativas nassarianas colocam em cena objetos, animais e alimentos, perfazendo uma concretude e desempenhando um papel, ao mesmo tempo, árido e úmido, uma vez que são duras e secas as particularidades dos ambientes repressivos, mas muito fluídas as investidas do desejo. A vontade é abafada, porém intensa, mesmo na aridez.

Se este convívio crepuscular presume o movimento espiralado de romper o maniqueísmo, uma outra componente dos traços idílicos no ambiente da cidade pequena é a fantasia. As breves e sutis passagens que flertam com o fantástico, presentes apenas em "Menina a caminho", derivam da condição idílica recuperada na inocência de príncipes e princesas. Assim, não só o sublime das narrativas fantásticas, mas o seu aspecto terrível sobrevém na imaginação da garota andarilha. 
Na imaginação da menina, dona Engrácia é a bruxa na vassoura. A velha Engrácia junto de dona Eudóxia e de dona Ismênia formam uma tríade de mulheres coadunadas com a imagem da mãe terrível, "modelo inconsciente de todas as feiticeiras, velhas feias e zarolhas, fadas corcundas que povoam o folclore e a iconografia" (DURAND, 2012, p. 104). As três mulheres aparecem envoltas em mistério, malícia e poder. Sob seu manto esconde-se a incerteza, conquanto a sensação de segurança das crianças é desafiada sem, contudo, estar manifesto o objeto que provoca medo.

$\mathrm{Na}$ chave de leitura judaico-cristã esse feminino vai se colocar justamente na tentação primordial de Eva, a mulher isomórfica da própria serpente. Ismênia (a ninfa) aparece como imagem caricatural de prostituta, maquiada e maliciosa: a tentação da carne. Eudóxia (de boa reputação) manifesta a imagem do poder, do domínio, do controle: a tentação de governar. Engrácia (aquela que tem graça) apresenta-se como questionadora diante do dono do bar e seu funcionário: a tentação de desafiar a autoridade. A terceira tentação, não por acaso, seria a própria queda, matizada em decadência: a sexualidade, o poder e a rebeldia repercutem no imaginário idílico rompendo a inocência, a abstenção e a humildade.

Não obstante, o universo das fadas é sutilmente fundido ao imaginário cristão. A tríade é, também, um motivo cristão. A Santa Trindade, os três dias para a ressureição, a crucificação aos trinta e três anos e, na chave da tentação, a tripla negação de Pedro, a pedra basilar da Igreja. Nesse contexto, o conto reitera as tríades: três garotos carregando sacos de palha, três carregadores atiçando a menina, três sujeitos entrando no bar para fervilhar a fofoca, três mulheres e seu poder misterioso, três santos no armazém do seu Américo, três filhos de Zeca Cigano e sua esposa. Embora a opção pelas tríades possua mais um efeito estético do que uma ancoragem nesta ancestralidade, não à toa, o conto nunca escrito "As três batalhas" (TB) reitera a premência das tríades. Acompanhando Gilbert Durand, "tríades lunares podem [...] condensar-se em simples díades que põem mais ou menos em evidência a estrutura antagonista, dialética, de que o drama lunar constitui a síntese" (DURAND, 2012, p. 290). O caráter lunar da trindade e sua vocação para a dialogia antagonista marca o dinamismo simbólico presente na obra de Raduan, cujas caricaturas binárias se desfazem em função de terceiros caminhos, que se abrem em espiral, perfazendo um dinamismo cíclico: "esta admirável constelação, em que a ambiguidade se mistura com a profundidade, com o abismo revalorizado, com o círculo e com a inversão" (DURAND, 2012, p. 209).

A tendência manter-se-ia caso tivesse sido escrito o conto "As três batalhas" que "seria ambientado na mesma cidade, teriam os mesmos personagens presentes, mas agora teria como foco um menino" (MASSI, 2015). As três batalhas pelas quais o menino passaria seriam a surra, 
a fuga e a revanche. De sua infância em Pindorama, Raduan cita as sucessivas brigas em que se envolvia e as surras que levava, na escola, quando criança: "mais de uma vez meu pai foi pegar-me todo sujo e machucado caído no chão. Abandonei a literatura sem ter escrito uma novela que teria a ver com esses episódios. Desse projeto só ficou o título, As Três Batalhas, que nunca desenvolvi" (NASSAR, 1998, p. 5). Tudo giraria em torno, também, de uma fofoca, de que a mãe do menino, Sandra, estaria tendo relações sexuais com o pai do outro menino que o surrou, o que se comprovaria à frente. $\mathrm{O}$ treinamento do menino, feito pelo velho italiano “alto, forte e elegante” (MASSI, 2015), o faria passar da humilhação à redenção.

Não seria demais pensar que o imigrante a treinar o menino seria, justamente, o íntegro João Baptista Tridda, citado na entrevista a Norma Couri (NASSAR, 1998). Ironicamente, o único texto de Raduan que teria um desfecho otimista nunca foi escrito. De acordo com Augusto Massi, “o menino, se não ganhou, levou alguma vantagem na última batalha” (MASSI, 2015). “TB” seria simétrico a "MC". A mesma vergonha, tema recorrente na cidade, seria o disparador, mas o desfecho do menino seria positivo, enquanto o desfecho da menina é negativo.

Retomando "Menina a caminho", a descrição das mulheres malignas atende ao arquétipo da bruxa. Ismênia, por exemplo, se compõe com "os seios leitosos, explosivos, quase espirrando pela canoa do decote" (NASSAR, 2016, p. 292; MC). O mesmo simbolismo da mulher fatal, atrelado à malícia feminina e à condição de sedução e pecado, percorre a descrição da mulher do conto "O velho": "uma loira de vermelho, a blusa do vestido com decote avantajado, colo e braços muito brancos, salta do banco traseiro como se procurasse ventilação, despregando seguidamente com a ponta dos dedos o tecido colado em parte à proeminência dos fartos seios" (NASSAR, 2016, p. 370; V). Na escolinha de dona Eudóxia as crianças estão aprisionadas, raptadas pela mestre-escola e Béca, sua cúmplice. A autoritária professora é assim descrita:

Paralítica, a velha mestre-escola está sempre naquela cadeirona do canto, ao lado da lousa, os chinelões de lã descansando no assoalho, os pés sobre o banquinho cobertos pela surrada manta xadrez que lhe protege também as pernas. Mas segura firme o livro que folheia devagar, como se escolhesse a lição (NASSAR, 2016, p. 302; MC).

Entretanto, no bar da esquina a bruxaria maliciosa da cidade fervilha na caldeira giratória conduzida pelo "mulatinho Isaías" (p. 304). O ambiente tenebroso e fantástico do bar se complementa pela presença dos "numerosos e malignos ratos que povoam todos os folclores" (DURAND, 2012, p. 213). No imaginário infantil daquela garota a maldade se associa aos ambientes em que se desenvolvem práticas e conversas de adultos, de modo que o 
fervilhamento das fofocas, que marca a cidade, traduz os citadinos na condição de ratos que procuram assuntos para roer, enquanto apontam seus dedos para o bode expiatório da vez:

\begin{abstract}
o dono do bar está numa conversinha muito entretida com dois sujeitos e nus risinhos estridentes que nem guinchos de rato, enquanto vão bebericando o cafezinho. Os olhos do Isaías, miúdos e inteligentes, se voltam pra mesa do canto e a menina tem a impressão de que suas orelhas, redondas e grandes, cada vez aumentam mais de tamanho (NASSAR, 2016, p. 305; MC).
\end{abstract}

O imaginário fantástico se expande com a chegada de dona Engrácia. Envolta em mistério, o produto por ela comprado, uma garrafa de pinga, põe malícia no dono do bar e em Isaías, seu funcionário, que questionam se ela fará o jantar com a aguardente. A descrição da mulher insiste no arquétipo da bruxa:

\begin{abstract}
A menina fica assuntando no perfil dessa face tosca, os olhos fundos, o nariz de osso, a pele seca e enrugada que recobre uma cara de bruxa. A velha pega a garrafa, apertaa com mãos e braços contra o peito chupado, afasta-se de mansinho, desce a soleira praguejando baixinho. A menina sai logo atrás, segue a dona Engrácia um pedaço, vagarando o passo quando a velha, num andar corrido, corta a rua como se voasse numa vassoura, sumindo num assopro na dobra lá da esquina (NASSAR, 2016, p. 312 ; MC).
\end{abstract}

A bruxaria perpetrada pelo povo daquela cidadezinha encontra vazão nessas figuras femininas, que encarnam o aspecto grotesco da fofoca, da malícia e dos conflitos morais, que se insinuam como elementos invisíveis para as crianças, que desavisadamente imitam os adultos em seus julgamentos e condenações. A menina, idilicamente associada ao anjo, equilibrandose em sua inocência, está sempre prestes a adentrar no negrume da queda, conquanto mimetiza o comportamento adulto no ritmo do conto. A garota imita o bêbado, vê no pequeno caixão a morte da infância e, a cada moldura, retira o foco e se movimenta seguindo as figuras que lhe geram atração: "que culpa temos nós dessa planta da infância, de sua sedução de seu viço e constância?" (NASSAR, 2016, p. 133; LA).

O seu Américo, entretanto, é um vilão que a garota jamais poderá derrotar, pois ainda não compreende a mensagem para a qual foi chamada a levar. Ao perceber a menina clandestinamente em seu armazém, o homem "levanta então a cara carregada que tem pra menina tanta força e horror quanto as histórias de cemitério de sua imaginação" (NASSAR, 2016, p. 321; MC). A menina sai derrotada do armazém, ameaçada de ter a vagina queimada pela figura fálica da vela, insinuando violenta e grotescamente sua violação e perda de inocência. A zona limítrofe pela qual trafega a menina em seu trajeto abarca a confusão entre as aparências e os segredos, entrevendo a vergonha de sua mãe e do filho do seu Américo. Da 
confusão entre o marasmo sufocante e movimentos de inquisição, emergem os habitantes da cidadezinha: apontam dedos como juízes, maltratam como carrascos, torturam como algozes, condenam como deuses coléricos. Esta performance se realiza, entretanto, sob o manto da tranquilidade e da calma de uma pequena cidade, cujos segredos se expõem no picadeiro de um circo popular.

\subsubsection{O espetáculo dos segredos}

O cenário tenebroso se funde com o lúdico das observações da criança. O lúdico compõe, como brincadeira, o teatro a que a menina é exposta em seu percurso. Com isso, seus olhos brilham ao ver "os meninos trapezistas" (NASSAR, 2016, p. 289; MC) carregando palha para o cirquinho. Mas o cirquinho infantil é apenas uma miniatura do circo dos adultos, no qual estão expostas criaturas com suas aparências débeis e sua condição vulnerável. Tais personagens, apedrejados por comentários maliciosos, ornam como seres exóticos enjaulados em um ambiente sufocante. Não obstante, no bar da esquina o mestre de cerimônias é o performático Zé das Palhas, ante o qual intervém a figura portuguesa do Zé Povinho, inerte, estúpido e sedento por notícias sensacionalistas. Este personagem não cansa de se revoltar contra os impostos, o governo e as autoridades, enquanto segue ignorando o funcionamento da política, segue conivente com a corrupção e com as injustiças, procurando sempre e a todo custo um culpado para atribuir sua miséria. Naquele círculo do bar da esquina, o Zé das Palhas é apenas aquele que empresta a voz a todos que se divertem com o apedrejamento do filho do seu Américo:

Um dos frangotes enfia dois dedos na boca e assobia, o outro cata o que acha na caixa do lixo e atira no seu Zé, casca de banana, de laranja e até casca de mortadela, mas no alvoroço contra o discurso ninguém saberia dizer se o dono do bar e os sujeitos dos cochichos estão mesmo protestando ou só se divertindo (NASSAR, 2016, p. 308; $\mathrm{MC})$.

Os homens estão atirando no Zé das Palhas para acertar, afinal, o filho do seu Américo, a quem querem atingir com tanto ódio. O Zé é uma voz que irrompe apenas pela performance, não reivindica nada, não alcança nada, apenas repete sua estridência, reiterando a incomunicabilidade entre povo e governo: "coitado do seu Zé, ele pensa que o rádio que toca e fala serve também pra levar de volta a voz da gente. No fim, todo mundo dá risada" (NASSAR, 2016, p. 306; MC). Por outro lado, “o seu Zé sobe na cadeira com os bolsos estufados de palha de milho, ficando de costas pra rua e o nariz no Philips, instalado ali na prateleira num nicho 
grande entre as bebidas” (p. 307). Tamanha é a miséria simbolizada pelo Zé, que sua imagem se assemelha ao "macaco sem vergonha" da oficina do Tio-Nilo:

\begin{abstract}
O macaco está do mesmo jeito, se esticando enquanto trepa no lenho pregado na parede dos fundos, acima da porta. Guarda, apesar de empalhado, a desenvoltura de um movimento ousado, a cara virada pros que passam na rua. Olhos espertos, o rabo comprido acabando quase em caracol, o macaco convencido parece que está sempre subindo, mas nunca sai do lugar (NASSAR, 2016, p. 313; MC).
\end{abstract}

O discurso de ódio contra o governo, do Zé, não diverte o povo, porque o povo, na verdade, não liga para política. O povo quer mesmo é linchar o filho do seu Américo, conquistando neste movimento de condenação sua vingança contra o Estado tirânico e o governo repressivo, manifestos no cotidiano. Tal é a transposição de poder que o retrato de Getúlio Vargas insiste nas edificações, adorado como patriarca. A volúpia dessa submissão encontra seu reverso na replicação desta dominação sobre o bode expiatório da vez. Este circo facilmente se degrada no carnaval de Um copo de cólera, em que as fantasias tropicais firulam esquadrias compostas de contradições visíveis nas novelas, nos estádios de futebol, nas pornochanchadas, assistidas, à distância, por ventríloquos risonhos. O mimetismo leva as crianças às mesmas resoluções violentas, como quando

um bando de garotos, armados com cabos de vassoura, ataca aos gritos um cachorro e uma cadela acasalados, grudados um no outro feito linguiça [...] os bichos mal conseguem sair do lugar, deixando-se espancar, até que um dos meninos despeja em cima uma vasilha de água quente (NASSAR, 2016, p. 301; MC).

Os brinquedos também aparecem pervertidos: "num brica co'a boneca do cavalo, menina [...] num brinca co'essa boneca que tem feitiço nela" (NASSAR, 2016, p. 295; MC). Sua face mórbida surge, também, quando na escuridão do armazém do seu Américo, "sem nada que acione aparentemente, a mão de uma criança sopro ou brisa, o pirulito gira sem cessar" ( $p$. 320). Possuindo notável caráter formativo, os brinquedos e as brincadeiras aparecem destituídos de seu contexto original e projetados em malícia e perversão, ressaltando a simbólica da mancha e a deseducação promovida por ela sobre as crianças da cidade.

O macaco inerte, da selaria do Tio-Nilo, conquista outras referências quando se alinha ao "fantasma isolado" (NASSAR, 2016, p. 300; MC) na cadeira da barbearia. Sua imobilidade revela o segredo tão bem guardado pelo narrador. Desejando a surra do filho do seu Américo deseja também a tortura, o espancamento, a punição com os excessos que ligam Vargas aos militares, entrevendo um passado de violência que se refaz cotidianamente em cada cidadezinha brasileira: “'uma tunda! Uma tunda!' repete o fantasma isolado, sua voz repercutindo cheia 
como o surdo da banda. "Uma tunda! É disso que o filho dele precisa"' (p. 300). O desejo de vingança e violência é intenso a ponto do trabalhador da União Operária ameaçar o Zé das Palhas no bar da esquina, repetindo "Getúlio é o nosso pai!" (p. 308). A ameaça põe o Zé em silêncio e faz os entusiastas da violência saírem de fininho, covardemente. O fantasma da força bruta repete-se como o surdo de uma banda, mantendo-se como pano de fundo das relações sociais em solo brasileiro. Ao fundo deste arranjo desarmônico também se revelam espaços nos quais imperam o terror, conquanto foi precisamente um deles que inspirou a escrita de "Menina a caminho":

\begin{abstract}
Acho que precisei exorcizar um episódio da minha infância, que nunca tinha contado a ninguém. Eu tinha sete ou oito anos e estava no alto de um pé de laranja, no fundo do nosso quintal, quando ouvi gritos de uma mulher que estava sendo surrada no quintal do vizinho, talvez junto ao fundo da casa dela. Eu ouvia o estalo das chicotadas, mas não conseguia ver nada devido aos pés de mamona que se interpunham, do lado do vizinho. $O$ fato de eu não conseguir ver a cena, nem identificar as pessoas, deve ter me traumatizado mais fundo. Eram só gritos e chicotadas. Eu não sabia naquela idade o que era angústia, mas foi com certeza angústia o que senti, pois desci da laranjeira, entrei em casa e me joguei na cama a tarde inteira (NASSAR, 1996, p. 28).
\end{abstract}

O sentimento de angústia, que percorre "O velho" e "Monsenhores", espalha-se também por "Menina a caminho". A imagem dos fundos aparece nestes contos alinhada com o segredo e com a vergonha. $\mathrm{O}$ que acontece ao fundo, na surdina, no âmbito privado, sustenta a malícia e a violência verbal do espaço público. A menina, apesar da sua inocência inicial, também apresenta uma curiosidade bisbilhoteira, tanto que observa clandestinamente tudo o que pode durante o caminho. Já no início da narrativa, os fundos aparecem: "a menina vislumbra um fundo escuro de quintal, um grande círculo fofo de palha de arroz, velas acesas na ponta de estacas, os casacas de ferro" (NASSAR, 2016, p. 289; MC). Cenário de ritual, o quintal está para um confessionário, uma sala de interrogatório, preservando apenas uma parte visível do horror. É ao fundo do armazém que a garota encontra seu Américo e é, também, de um fundo de quintal que vem Zeca Cigano para surrar sua esposa: "trabalhando no barracão lá no fundo do quintal [...] o Zeca Cigano [...] empunhando ainda a marreta, acorre aos gritos da mulher" (NASSAR, 2016, p. 323; MC). Ao fundo da pensão, em "V”, está o quarto do pensionista que cede à volúpia da mulher enviada por seus corruptores: "ele conduz o olhar temeroso pros fundos: o alpendre ali está quieto e escuro" (NASSAR, 2016, p. 381; V). A caminho dos fundos da casa de Luca está o quarto onde Lucila e Dinho consumam o incesto: “entramos pelo corredor onde no fundo a casa se comunica com o escritório" (NASSAR, 2016, p. 395; M). 
Entretanto, ao fundo dos três contos estão segredos preservados no terreno do não dito, pois, vinculados à vergonha. Os contos mostram mensageiros que saem de seu domus para interpelar outros personagens, cutucando de algum modo suas vergonhas. Em "Monsenhores" um rapaz pouco conhecido de Ermínia, a pedido de Luca, vem trazê-la a grave mensagem, chamando-a para sua casa. O segredo de Luca está trancado: "me assustei com o rangido do portão de ferro, parecia até que alguma coisa de sinistro já tinha acontecido e, enquanto afundava pelo corredor lateral, notei que janelas e porta estavam fechadas, como numa casa abandonada" (NASSAR, 2016, p. 388; M). A imagem da casa trancada é simétrica ao silêncio das pessoas. Em "V" é recorrente o uso do verbo "trancar" no sentido de silenciar: "o velho se tranca e desvia os olhos pra rua" (NASSAR, 2016, p. 382; V). O mesmo ocorre em "Monsenhores":

dei uns passos na direção dele sem dizer nada e, assim que me aproximei, o Luca não fez mais que abrir a porta e me dar passagem, logo se recolhendo, se trancando mesmo, e isso me fez desistir de perguntar qualquer coisa, e depois perguntar o que naquele momento, se nem tinha condições de abrir a boca (NASSAR, 2016, p. 394; M).

O marido de Lucila não responde aos questionamentos de Ermínia, solicitando apenas que a mulher continue seu caminho sem acender a luz, mantendo na penumbra seu segredo. Permanece no escuro mediante o silêncio que persiste, enquanto a mulher e o homem avançam em direção ao quarto onde está Lucila. Nas memórias recentes de Ermínia, Lucila aparece como uma sombra, "quieta, quieta" (p. 390). À volta da situação, a ex-professora se lembra que "há tempos corriam comentários maliciosos, que nem quero falar deles” (p. 395), rendendo-se ao não dito. Mas o que não é dito insiste em pensamento: “não, não é possível, eu só pensava e, profundamente transtornada pelas coisas escabrosas que me passavam pela cabeça" (p. 396). E persiste, também, em Luca: “coisas que não ouso falar” (p. 396). Outrossim, mesmo diante do segredo revelado, o mistério permanece. Sabemos que ocorreu um incesto, mas não sabemos se foi uma relação sexual consentida, não sabemos se houve relações sexuais anteriores, não sabemos se mãe e filho tinham desejos recíprocos, não sabemos que fluído corporal goteja no chão, não sabemos que papel teve Luca e sua viagem em torno do ocorrido.

O segredo e o silêncio também atravessam "V". Se em "M" os personagens mal tocam no assunto, em "V" o segredo se esconde em expressões e palavras dúbias proferidas pelo seu Eugênio, como "farras", "coisas" e "raiva" ou "andam dizendo coisas", "vão acontecer coisas", "estão acontecendo coisas", "tem um cheiro forte de perfume em nossa casa". Como em outros ambientes do universo nassariano, neste conto o silêncio e o não dito sinalizam com intensidade 
a angústia e a tensão de situações e contextos que prenunciam a explosão e a cólera. O velho olha para baixo, segura sempre seu chapéu, fica parado, à espera de um acontecimento. Nesse caso, a espera diverge da tranquilidade. A espera acaba sufocando a todos na pensão durante o jantar pois cada pequeno ruído é prenúncio de um evento terrível. Durante o jantar "não se trocam palavras, o ruído é seco, incisivo. O carro deve ter sido freado em frente ao portãozinho do jardim da casa" (NASSAR, 2016, p. 374; V). O "ranger das tábuas" (p. 374) e o "ruído de um carro que zarpa fortemente" (p. 375) tencionam a mesa, projetando dúvida sobre o plano dos corruptores do pensionista. O silêncio e a tensão se intensificam com o desabafo do pensionista seguido do engasgo da professora, dissipando os hóspedes logo após o jantar. Mesmo após o segredo vir à tona na observação do velho, o mistério continua ancorando o clima de espera, já que não se sabe como os corruptores abordarão o coletor de impostos após a efetivação de seu plano. Por conseguinte, o conto termina mantendo no leitor a sensação de que algo está por vir.

Em “Menina a caminho”, por sua vez, o segredo não é revelado. O filho do seu Américo, aparentemente, "estragou" a vida da mãe da menina mensageira. Não é exposto, afinal, o que fez o rapaz. Embora a insinuação de ofensa de Zeca Cigano seja respondida pela mulher com a interjeição "corno", não fica claro se houve um adultério, inclusive porque o narrador caracteriza a ofensa como "falsa inquisição". Acrescente-se a interpretação de Massi (2015) de que o rapaz seria homossexual, corroborada pela frase do homem baixinho na barbearia: "aqui que a flor do filho dele se safa" (NASSAR, 2016, p. 301; MC). O que estaria, enfim, escrito no muro do seu Américo? A atmosfera deste conto nos leva a crer que o segredo se relaciona com a sexualidade do rapaz e da mãe da menina, como em "As três batalhas".

Todavia, outros segredos também permanecem no campo do não dito. Durante os preparativos para o cirquinho, mediante a interpelação do garoto mais velho, Zuza, um dos meninos explica que uma das meninas, Nice, não irá, pois, "a mãe dela diz que da outra vez teve aquilo" (p. 290). O leitor não saberá o que é, de fato, “aquilo", tampouco saberá quem é a mulher que belisca a perna e atiça dona Ismênia enquanto ela questiona Zuza ou qual será a finalidade da garrafa de pinga comprada por dona Engrácia. Além disso, "a menina não desgruda mais o olho da bola de pano do baixinho" (NASSAR, 2016, p. 301; MC), na barbearia.

Há o que esteja escondido neste conto, como as pernas de dona Eudóxia, o "coto da perna esquerda" (p. 314) do Tio-Nilo, o conteúdo do "pequeno caixão branco" (p. 316) levado pelo camponês. Mas o que está escondido, aqui, se revela pelo jorro dos fluídos, como o "sexo de piche" (p. 295) que se insinua sobre a menina quando o cavalo quer urinar, como o vômito da garota que preenche a sala com restos daquilo que por ela foi consumido em seu caminho. 
Restos, mal digeridos, da malícia e perversão que presenciou em seu trajeto, enquanto ela mesma se esconde para apreciar aquilo que lhe gera atração, seja pela curiosidade do que é proibido, seja pela atratividade lúdica dos objetos e situações que vão atravessando seu disperso itinerário. O silêncio, por sua vez, é o instante de tensão e angústia antes da explosão colérica, da briga, da discussão e da violência, como nos mostram as situações de tensão presenciadas na barbearia, no bar da esquina, quando a celeuma é abafada, e, finalmente, a ausência de som que precede o açoite de Zeca Cigano.

\subsubsection{Queda (II): estradas e caminhos}

O jogo de sombra e luz de Nassar, nestes contos, atende à situação biográfica que os inspirou, desenvolvendo a tensão e a angústia decorrentes de segredos cuja visibilidade fica restrita a resquícios e detritos, à maneira das dialogias entre consciência e inconsciente. O que o leitor enxerga são apenas vultos, sombras, ruídos, manchas, protuberâncias e saliências que elevam o que foi abafado e guardado a um volume ensurdecedor, escancarando a presença daquilo e daqueles que foram excluídos. Nessa direção, a aparência decrépita e decaída dos personagens contrasta com o marasmo dos ambientes. Em "Menina a caminho" a garota é paupérrima:

\footnotetext{
o vestido caseiro, costurado provavelmente com dois retalhos, cobre seu corpo magro feito um tubo; a saia é um pano grosso e desbotado, a blusa do vestido é de algodão acetinado, um fundo preto e brilhante, berrando em cima uma estampa enorme em cores vivas, tão grande que sobre o peito liso da menina não aparece mais que o pedaço de uma folha tropical. Deve dormir e acordar, dia após dia, com as mesmas tranças, uns restos amarrotados. Uma delas, toda esfiapada, é presa por dois grampos se engolindo; já quase desfeita, as mechas da outra estão mal apanhadas no alto por um laço encardido que cai feito flor murcha sobre a testa (NASSAR, 2016, p. 288; MC).
}

A decadência se mostra como uma segunda queda. Não bastando o estigma originário envolvendo o homem, desde sua concepção, em dramas infindáveis a partir de seus conflitos intra e interpessoais. Além da nossa condição de origem, pecadora e torta, nos são oferecidas figuras humanas que não se cansam de reiterar nossa condição caída, estampando em sua aparência a falência da vida e das relações sociais. As imagens terrificantes e repulsivas incluem o arquétipo da bruxa, repetido na professora de "O velho": "uma mulher grande, matrona de cabelos anelados" (NASSAR, 2016, p. 374; V). Por sinal, são as características mais bizarras e diferentes que chamam atenção no convívio: "é pros pelos negros, que brotam da verruga ao lado do seu queixo, que parecem convergir os olhares" (p. 374). Neste mesmo conto, o senhor Eugênio, o velho, é apresentado pelo narrador e, principalmente, por sua mulher, como um 
homem caduco, bisbilhoteiro, enxerido, atrapalhado, incapaz de tomar conta de si e de outrem. Não obstante, apesar de diminuído pela esposa, o homem não se furta de reivindicar seu espaço: “todos os dias a mesma coisa, Nita, você não me respeita, nunca me respeitou, eu não vou pedir respeito pras crianças da rua" (p. 368).

Em “Monsenhores", são os semblantes e as aparências de Lucila e Lula que assinalam sua decadência. Dias atrás do incidente relatado no conto, Lucila apareceu em transe na casa de Ermínia, calada e "o rosto de fazer pena" (NASSAR, 2016, p. 390; M). Quando Ermínia encontra Lucila, descreve seu olhar como perdido e embaçado, na posição de cócoras, como a garota de "Menina a caminho" ao fim do conto. Lucila está com as pernas magras descobertas, parece não respirar, dentro de um túnel escuro, sem volta. A figura de Luca também se mostra arruinada. Antes era um homem que "despertava fantasias em tantas mulheres" (NASSAR, 2016, p. 395; M), porém, segundo Ermínia, “era a primeira vez que o via daquele jeito, a cara sem a vitalidade de costume, parecia até que ele estava se mostrando pelo avesso" (p. 389). Ermínia repara na "barba crescida, no desleixo da roupa" de Luca, ao que o homem murmura sem vitalidade: "foi o pó da viagem" (p. 389). O homem está "de ombros e braços caídos” (p. 394), “enforcado" (p. 396), como Zeca Cigano em "MC". O afilhado, Dinho, marcado pela “imagem de um menino triste e solitário” (p. 389) contamina e causa a morte social dos pais, uma vez consumado o incesto. A queda é, efetivamente, assinalada com a descrição dos monsenhores, podres, como observou Estevão Azevedo:

Em Raduan, toda crise ética, política e moral tem outra face, quase sempre mais aparente, de disputa entre corpos, como o da mulher ativa e o do marido senil. Não à toa, esse erotismo em sua fase decadente [...] o faz sentir cheiro de flores. Talvez de seu enterro? Em Monsenhores, "as flores se encontravam murchas, exalando mau cheiro" [...] Ermínia vê as flores no vaso, chamuscadas pela vela, prenunciam uma descoberta terrível, relacionada, como em "Lavoura Arcaica", a transgressão sexual e imposição da ordem patriarcal (AZEVEDO, 2016, p. 3).

A face aparente, as flores apodrecidas, a senilidade do velho, sinalizam, portanto, conflitos de outra natureza, imersos sob os contornos dos ambientes em que as narrativas se desenvolvem. Mas este pouco que aparece é o suficiente para manchar e contaminar: "“ela deve estar no quarto deles', ele disse, parecendo fazer muito esforço pra dizer tão pouco, um pouco que foi a gota pra inundar meu raciocínio, eu já não sabia pensar mais nada" (NASSAR, 2016, p. 395; M). Por outro lado, em "M" o imaginário da queda também se detém na culpa, uma vez que Ermínia se cobra pela "falta imperdoável” (NASSAR, 2016, p. 391; M) de não visitar a amiga após ter presenciado seu transe, quando colheu as flores na casa de Ermínia. Finalmente, os pingos que caem da vagina de Lucila precipitam o abismo de angústia, tensão e culpa que 
invade, para sempre, a vida daquele casal, como a escuridão que invade a esposa em "Hoje de madrugada".

O imaginário da queda irrompe sutilmente em "O velho", perante a angústia da espera desfrutada pelo senhor Eugênio, que se apaga em seus lapsos de pensamento, retornando em outro terreno: "o chapéu ainda entre as mãos, ele tomba a cabeça e se perde em pensamentos. Quando desperta do seu recolhimento, o quarto está em sombras" (NASSAR, 2016, p. 369; V). Enquanto isso, também a noite vai caindo lentamente, "indecisa e fosca" (p. 369), sobre a pensão. A angústia do velho também se mostra nos movimentos tensos de suas mãos: “compenetrado, as mãos caídas, o chapéu preso pelas mãos, como quem se coloca em sinal de respeito, parece até que ele assiste a uma missa fúnebre enquanto observa o ritual do moço desdobrar o guardanapo e estendê-lo sobre as pernas" (p. 373). Os olhares para baixo, tanto da professora, quanto do senhor Eugênio, manifestam o sentimento de vergonha.

O mesmo sentimento de vergonha, amalgamado em culpa, percorre a narrativa de "Menina a caminho". Mas neste conto o castigo serve de explosão da cólera represada em silêncio. A mãe da menina leva cintadas na bunda e na cara em razão de uma suposta ofensa, a menina rica da escolinha leva bolos de palmatória por ter feito o "mau cheiro" (p. 303), os cachorros são espancados por estarem grudados durante o acasalamento: quando o que não pode ser visto vem à tona, os responsáveis são punidos exemplarmente, constituindo de maneira didática a fórmula da repressão. O ódio represado na inocente disputa dos meninos catando palha, na zombaria de dona Ismênia, na chacota dos carregadores, na barbearia, no bar da esquina, é finalmente liberado na expressão da ira desta cidadezinha.

O imaginário da queda vai adentrando como mancha na menina, cujo movimento remete à própria queda. Ela vai seguindo seus desejos e os personagens que lhe atraem, correndo, tropeçando e, às vezes, caindo em cada círculo observável. Uma vez enquadrada a cena, mergulha seus olhos na caldeira dos valores. Finalmente, quando enfrenta o desafio derradeiro, reproduzir a mensagem da mãe ao seu Américo, "cai-lhe o laço de fita enquanto corta o armazém" (NASSAR, 2016, p. 321; MC), ao que chega sufocada em sua casa. Aos poucos sua inocência vai cedendo à mancha e a queda gradativamente alcança êxito.

O perambular da menina na cidade é o prenúncio de um caminho desviante. A garota não vai diretamente ao armazém levar a mensagem; passa por vários lugares em sua brincadeira voyeur. O cerco social levou o seu Giovanni a uma dor de cabeça eterna. Interpõe-se ante a menina como um brinquedo arruinado: "arrasta as alpargatas na outra calçada, parece um papainoel que perdeu a roupa vermelha, sempre com aquela cara triste de dor de cabeça. Anda sem parar, o olhar solto, o coração apertado" (NASSAR, 2016, p. 296; MC). A menina e o Giovanni 
não são os únicos caminhando a esmo naquela cidade. $\mathrm{O}$ ritmo inebriante e circular daquele povoado também martirizou o pinguço: "sentado na sarjeta, as pernas abertas e esticadas, cheio de remendos no pano imundo da calça, os pelos da barba que nem traços a carvão, duas cascas de jabuticaba no lugar dos olhos, um cigarro de palha descansando na orelha de abano, está ali feito um brinquedo de feltro maltratado, rindo no ritmo do mundo" (p. 315). Dona Engrácia, por sua vez, "entra no bar c'um vestido que chega na canela, uma chita tão escura que encolhe inda mais seu corpo arcado; traz na cabeça um lenço que se afunila armado sobre a cacunda" (p. 310). Também decaída é a casa da menina, com uma "sala apertada e suja de retalhos, papel e casca de manga" (p. 322).

O narrador intercala seriedade e brincadeira nas descrições que vai compondo, recuperando objetos e terminologias do imaginário infantil para construir o cenário e os personagens. Este movimento atende à dubiedade da condição da menina, entre a inocência e a malícia, posto que projeta a si mesmo nas cenas que assiste, sem compreender as palavras, as imagens e os sentimentos que as pessoas expressam em cada um dos círculos que enquadra. No armazém, projeta-se na bandeira de João Batista, precursor de Cristo:

\begin{abstract}
A menina não tira os olhos é da imagem de João Batista estampada na bandeira do meio, contempla com indisfarçável paixão o menino de cabelos encaracolados que aperta contra o peito um cordeiro de tenras patas soltas no ar, um cajado roçando seu ombro nu. Lambendo o torrão de açúcar, o menino se transfigura, transporta-se pras noites frias de junho, o pano com São João drapeja no alto de um mastro erguido no centro da quermesse, afogueado pelas chamas da lenha que queima embaixo. Mas suspenso assim num recolhimento de sombras, o menino de olhos meigos e cabelos anelados se dilui talvez na calma triste de um convento (NASSAR, 2016, p. 319-320; $\mathrm{MC}$, grifo nosso).
\end{abstract}

Sua inocência, alegria e tranquilidade na faixa, avistadas como antevisão do trauma que está por vir. Nesse caso, enxerga no menino o protagonismo do feliz encontro das famílias e da comunidade durante as festas juninas, quando a noite traz a calmaria e a coesão da partilha da fé, como era na Semana Santa da infância de Raduan, em Pindorama:

A Semana Santa em Pindorama era encenada do Domingo de Ramos até o Domingo de Páscoa, teatro puro, principalmente as procissões da Paixão e do Encontro. Era semana só de emoções. A voz de Verônica, que vinha dos altares nas casas, cantando em latim enquanto desenrolava e enrolava o sudário, estremecia-me por dentro. $\mathrm{O}$ Mediterrâneo estava também no cemitério, nos túmulos das famílias, um tanto monumentais (NASSAR, 1998, p. 5).

Os caminhos de Pindorama conectam-se, afinal, com o veio ancestral daquela terra de imigrantes: "Pindorama era uma cidade predominantemente de imigrantes mediterrâneos, aliás, 
o Brasil todo, de algum modo, é mediterrâneo" (NASSAR, 1983, p. 100). Ao dizer que o Brasil todo é mediterrâneo captamos que há um Brasil miscigenado no universo do escritor:

\begin{abstract}
Com todo aquele cosmopolitismo, São Paulo diluía minha condição de filho de imigrantes, sem as pressões tão diretas exercidas numa cidade do interior. Nesse tempo, quando ocorria de sentar-me ao redor de uma mesa, mesmo se muito calado, eu me distraía em levantar origens étnicas e achava que a melhor contribuição que o Brasil poderia dar seria um novo ciclo de mestiçagem. Mesmo se levasse um milênio, mesmo se fosse um parto demorado e difícil, com muita dor, seria muito bonito o que se poderia vislumbrar (NASSAR, 1998, p. 5).
\end{abstract}

Os textos de Raduan guardam fortes relações com o cenário mítico e cultural do Mediterrâneo, que se traduz no Brasil do interior de São Paulo, se investe nos conflitos de poder brasileiros, no arcaico da terra roxa, colhendo a promessa de uma nova vida em um novo continente. Por outro lado, Pindorama dá também vazão para a imensidão poética de Minas Gerais: "quanto mais encosto Pindorama em Minas, mais fico perto da aura da literatura de lá. Pindorama é mais mineira do que Paulista" (NASSAR, 1998, p. 5).

A imensidão dos caminhos e dessas estradas sem volta, ao mesmo tempo, compõe a aventura e a prisão humanas (correntes). Quando a mancha toma conta da menina, da pensão interiorana ou da casa de Lula e Lucila, não há mais volta, sequer o sonho de um carro de boi a proporcionar aventuras e riscos. As cidadezinhas, concêntricas, passam a significar o oposto dessas aventuras, amalgamando, sob o imaginário noturno, o marasmo de seu cotidiano com a voluptuosa desenvoltura das fofocas. O marasmo dessas pequenas cidades se petrifica na imobilidade de suas entranhas tão estáveis quanto sufocantes:

Do alto da escada que leva ao jardim embaixo, enquadrado pelas duas alas do alpendre, corre atentamente os olhos pelas folhagens que acobertam a estridência de grilos. No pequeno canteiro circular, o cipreste romano se ergue ereto e soturno no centro, com o ponteiro acima da cumeeira da casa, quase indevassável à escassa luz que já se expande do poste mais próximo. Nada balançaria suas ramas tesas nessa noite de mormaço, mas um jogo apagado de sombra e luz tremula suavemente na parede do fundo, onde duas portas dão acesso aos quartos independentes dos pensionistas (NASSAR, 2016, p. 379; V).

A imobilidade, evidente na figura do "macaco sem vergonha" de "MC" dá a estes contos a sensação de repetição e de convívio com uma aridez. Este silencioso clima de espera e a aparente tranquilidade são os mesmos do capítulo final de Um copo de cólera: "uma atmosfera precoce se instalando entre os arbustos, me impressionando um pouco a gravidade negra e erecta dos ciprestes" (NASSAR, 2016, p. 278; CC). Acentuada pelo clima, a tensão permeia uma inabalável estrutura, que se sustenta no silêncio e na tranquilidade de uma vida pacata e 
serena. Porém, a imobilidade da imagem fálica do cipreste, a inércia do machismo e a fixidez do patriarcalismo convivem com a corpulência dos frenéticos movimentos dos excluídos.

Em "O velho" a cidade se move ao redor da pensão, retesando seus habitantes e tonificando suas angústias e temores. Em "Menina a caminho" a garota se move, se posiciona, enquadra o melhor ângulo, persegue personagens e corre de situações amedrontadoras. Os personagens da cidade também se movem pelas ruas. Apesar de tantos encontros e desencontros, o que se modifica é o interior da criança que "vai pra rua brincar com as crianças da vizinha da frente" (NASSAR, 2016, p. 326; MC) após descobrir sua sexualidade, a malícia, o prazer e a violência. Já em "Monsenhores”, Ermínia corre em direção à casa de Luca, pois, lá dentro está Lucila, como estátua, se consumindo em sua eterna escuridão.

Nos contos analisados neste capítulo, as sutis mudanças, aos poucos, revelam o aprisionamento do tempo, do espaço e dos costumes, conquanto em todos estes contos os personagens se movimentam em seu caminho, sua busca, mas em determinados momentos vacilam e param. Sua parada os distancia do instante presente e os lança nos rincões de seu interior, onde se entrecruzam caminhos e estradas que levam e trazem sonhos e assim o fazem, também, com os preconceitos, a violência, os traumas e as feridas dos povos que neste solo aportaram. Como no dúbio e milenar sermão de Iohána (NASSAR, 2016, p. 34; LA), "sentado num caixote, as pernas afastadas, os cotovelos fincados nos joelhos, a cabeça apertada entre as mãos, o seu Américo tem os olhos fixos na chama de uma vela que serpenteia ligeiramente com a queda próxima do torrão" (NASSAR, 2016, p. 320-321; MC).

Esses caminhos, trilhados com ou sem a virtude da paciência, absorvem e incorporam as reentrâncias, as vísceras e as purulências dos corpos e tecidos sociais, de onde se multiplica o fétido aroma dos conflitos morais, embebidos na demonização da sexualidade. Os promíscuos desvios e reentrâncias entre sociedade, política e sexualidade ganharão vigor nas análises do próximo capítulo, no qual Um copo de cólera, "Hoje de madrugada" e "O ventre seco" acrescentam e aprofundam os dramas conjugais e as contaminações recíprocas entre poder e erotismo nos cenários nassarianos. 


\section{A PROMISCUIDADE DO PODER}

Figura 6 - O café da manhã

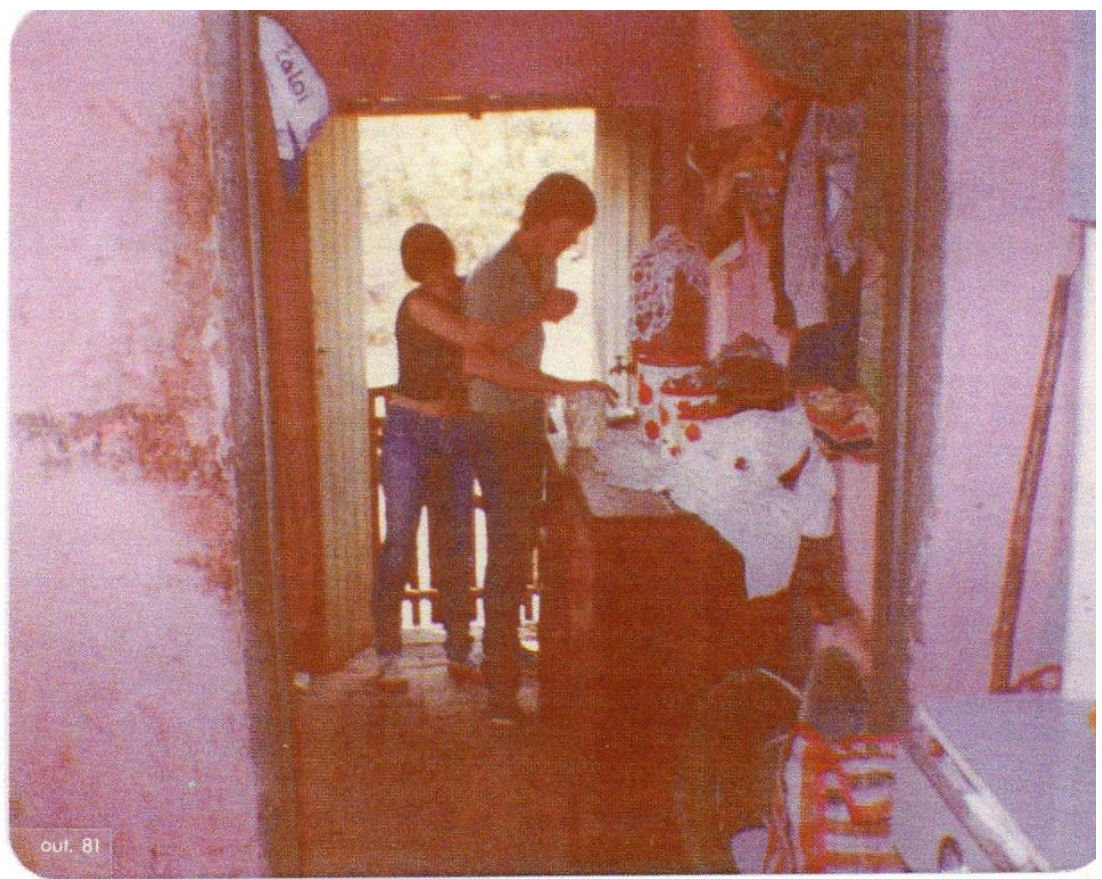

Fonte: arquivo familiar (1981)

Margareth e Bimbo. A explosão dos gêneros à luz de uma manhã qualquer.

Figura 7 - A gravidade negra e erecta dos ciprestes

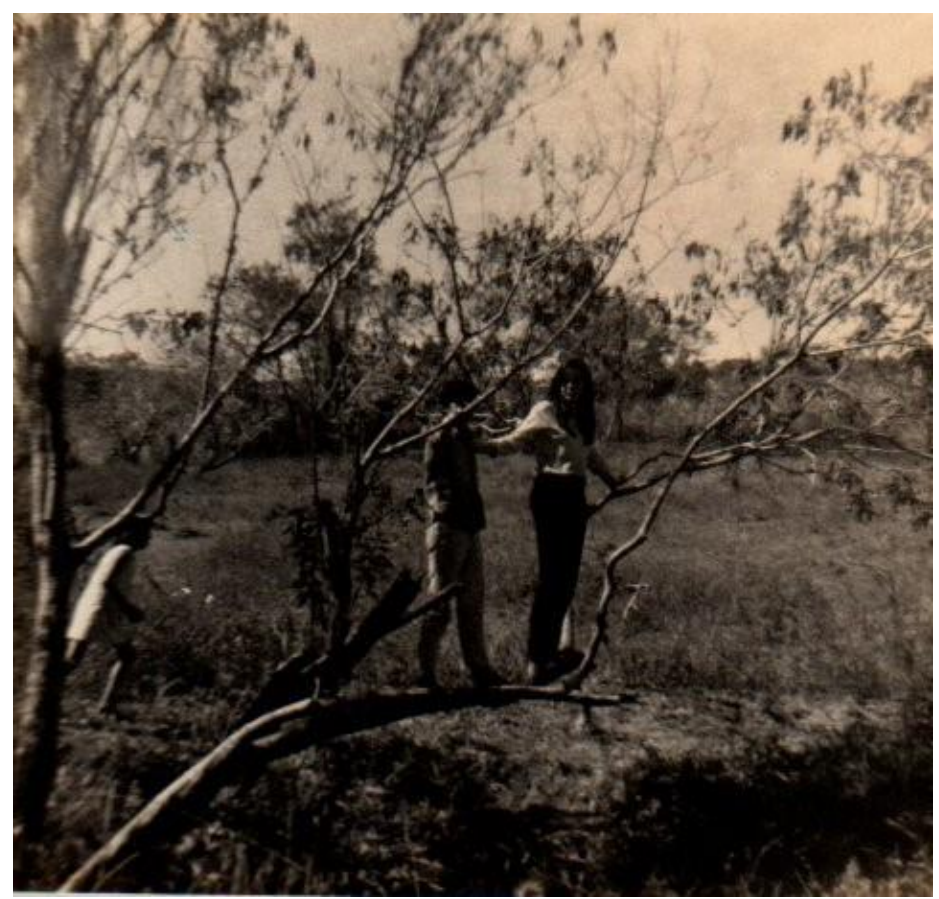

Fonte: arquivo familiar (1969) 
Minha tia, Célia Regina, e um rapaz sem nome desbravando a tensão dos galhos do "Sítio Bairrinho"; fundas estradas e violentas bandeiras nos sulcos daquelas memórias comuns.

Figura 8 - A depositária espiritual de um patrimônio escasso

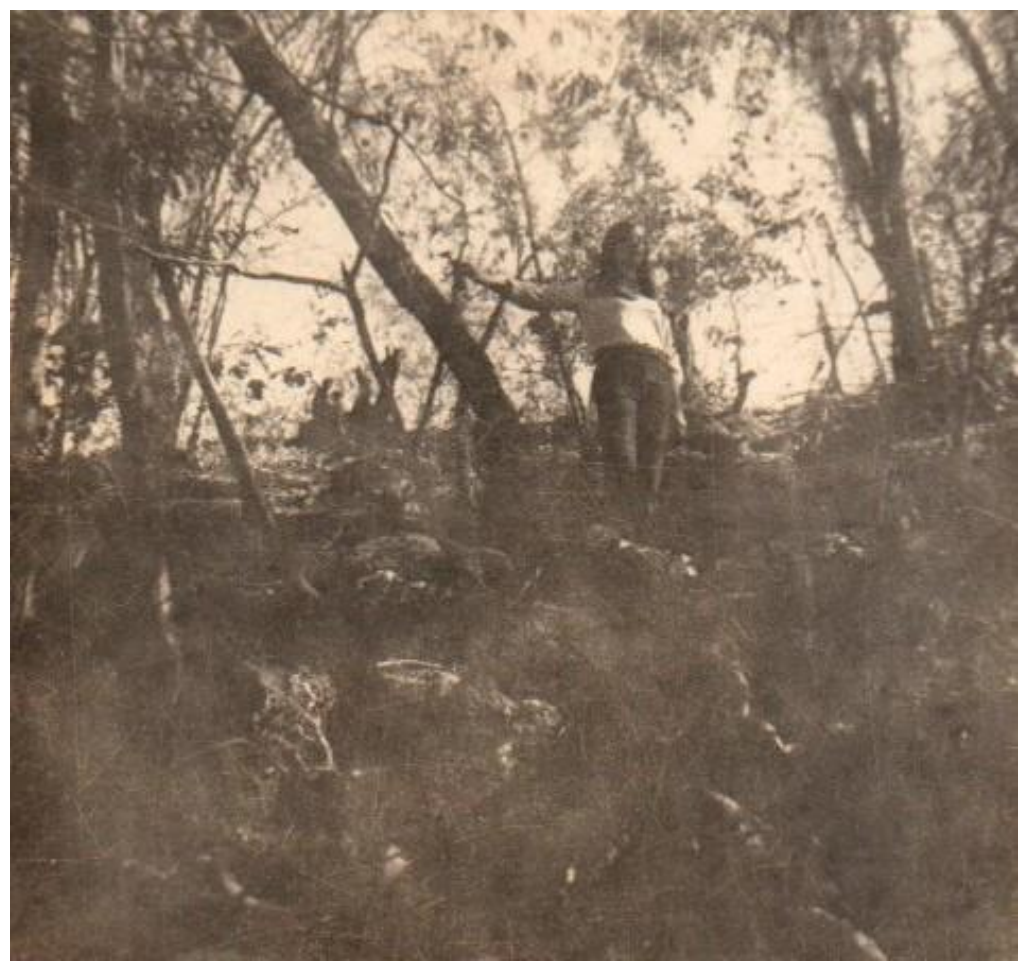

Fonte: arquivo familiar (1969)

Célia Regina Cremasco. "Pois a tarde, fronteiriça, já avançava com o escuro, notando, ao descer do carro, uma atmosfera precoce se instalando entre os arbustos".

A leitura conjunta de "Hoje de madrugada" (HM), "O ventre seco" (VS) e Um copo de cólera (CC) intensifica de forma caricata a componente simulada das relações conjugais e sociais. Em nosso primeiro conjunto de textos (Capítulo 2) - "Aí pelas três da tarde" (TT), "Mãozinhas de seda" (MS) e "A corrente do esforço humano" (CEH) - mostrou-se um panorama da obra nassariana, povoada de dicotomias, referências cruzadas, tornando evidente o convívio entre os contrários em todos os seus textos. Os paradoxos são ancorados em nossa própria interioridade no segundo conjunto de textos (Capítulo 3) - "Menina a caminho" (MC), "O velho" (V), "Monsenhores" (M) e "As três batalhas" (TB) - desconstruindo a um só tempo a idealização da infância e o bucolismo das pequenas cidades. Se nestes últimos textos as ambiguidades e feridas são vistas parcialmente, em um tenso jogo de adivinhação, na tríade deste quarto capítulo as tensões e angústias vão se tornando mais intensas, até que a explosão 
escancara as contradições e deixa totalmente à mostra a simulação que caracteriza as relações humanas.

\subsection{O MICROCOSMO DO CASAL}

Raduan Nassar nos apresenta uma realidade seca, marcada por regras tácitas, em que narrativas de âmbitos formais e informais se fundem na experiência sensível e empírica do cotidiano. Por se manterem à margem do contrato social, os desajustados e renegados optam entre aderir à submissão ou recusar a ordem vigente, seja pelo silêncio e exílio, seja pela cólera e volúpia. O escritor resgata não só os personagens excluídos, mas os contextos de exclusão, os pensamentos divergentes, as emoções dissonantes, os desajustes sociais, familiares e conjugais, perfazendo uma dinâmica que orbita entre união e desunião.

O caos existencial e o descontrole social não impedem que ordens e hierarquias se estabeleçam e se cristalizem como tradições. O predomínio da racionalidade técnica no Ocidente desde a modernidade garantiu a hegemonia de símbolos solares no plano mais visível das relações sociais e cotidianas, alimentando o frenesi produtivo e a primazia da abstração como forma de otimizar a vida social. A razão recorta, separa e sistematiza a experiência cultural, de onde emergem as ciências humanas. Porém, os elementos isolados que a operação racional consegue captar não dão conta da complexidade da vivência cotidiana. A literatura nassariana reintroduz a virulência dos sentidos e das emoções na apreensão da realidade e na concepção dos fenômenos humanos, apontando os limites da razão e descontruindo o pensamento dogmático. Nessa direção, Nassar concebe a literatura como contrapeso à desarmonia: "existe, num texto, essa tentativa de compensar o desequilíbrio e a desordem instalada em toda extensão à sua volta" (NASSAR, 1995, p. 1).

A ordem se sustenta em fatores arbitrários, balizados pelo poder e manifestos na linguagem. Por isso, Raduan coloca em evidência a zona quebradiça do discurso, da qual afloram ambivalências e significações abafadas, cujos movimentos sinalizam os dobramentos uterinos do regime noturno do imaginário durandiano, dinâmica que se confirma na leitura de Masé Lemos: “essa intensidade apaixonada é dobrada no espaço do silêncio do ventre, de um exílio interior, de uma zona de indiferenciação, criada justamente pelo jogo de reversão contínuo" (LEMOS, 2010, p. 98). Assim sendo, sua literatura apresenta a gradação limítrofe entre a normalidade e os desvios.

Conforme Durand (2012), a imaginação simbólica possui função de eufemismo, com a qual se pode enfrentar a temporalidade terrena e a eminência da morte como condições 
partilhadas por todos os seres humanos. Uma das faces do tempo, no entendimento da antropologia do imaginário, é a face terrífica da morte, trazendo como consequência a angústia frente às tensões e transições. Além disso, a prevalência das imagens solares no contexto capitalista, de produção e consumo, demanda uma reequilibração simbólica que provém das próprias manifestações artísticas. Nesse caso, os textos nassarianos ultrapassam o questionamento da razão ao desconstruírem, também, o seu reverso, entrevendo idiossincrasias e dinâmicas da ordem e da desordem, criando uma potente recusa. Mas a recusa nassariana vem com tônus e vivacidade, de modo que, ao mostrar o avesso de várias concepções de mundo, tampouco recusa a vida, ao que reajusta o mundo na dimensão estética das narrativas pessoais: “mesmo a literatura mais pessimista, aquela que afirma que o nosso mundo é o pior dos mundos, acaba até se desmentindo pelo entusiasmo com que se expressa. Já disseram que a voz sem entusiasmo jamais será ouvida" (NASSAR, 1997b, p. 9).

Como observou Masé Lemos (2003), Raduan é um escritor entre o tradicional e o moderno. Compondo um ritmo dialógico, o escritor mobiliza referências que circulam entre o erudito e o popular. Assim, a expressão de seus narradores-personagens, sobretudo em Lavoura arcaica (LA) e Um copo de cólera (CC), põe em jogo a dinâmica recursiva entre a simplicidade do homem do campo e o conhecimento historicamente constituído. Nesse caso, a expressão que Nassar dá ao homem comum toma de empréstimo referências à filosofia ocidental, à psicanálise freudiana, aos clássicos da literatura, à ancestralidade judaico-cristã e ao legado greco-romano, recuperando tradições e as ressignificando mediante dinâmicas da modernidade e do contexto contemporâneo.

$\mathrm{O}$ anjo mal de Raduan, promotor das mudanças, é a própria possibilidade do mal, concebido no dualismo de uma estrutura de sensibilidade antitética (DURAND, 2012). Como a moral se constrói atribuindo valor, gera sempre excluídos, já que a sentença do mal se materializa no outro. Não obstante, os excluídos reivindicam sua pertença pressionando as mudanças. Cada nova regra que inclui também exclui, constituindo uma espiral infindável. Assim, o movimento circular ganha um ímpeto violento e apaixonado, que gradativamente conduz à explosão e à cólera.

Para tratar de Um copo de cólera é importante abordar os contos "Hoje de madrugada" e "O ventre seco". Estes funcionam como um preâmbulo à novela; ambos retratam o cotidiano de casais. A tensão silenciosa insurge nestes dois textos de maneira cumulativa, constituindo uma angústia que contamina os espaços e pressiona as situações para a explosão colérica que ocorre em CC. O diálogo entre "HM" e "VS" localiza o conflito moral de Nassar no microcosmo do casal: 
Identifica-se a ausência de respostas do taciturno narrador de "Hoje de Madrugada" e uma fuga do diálogo, na discussão unilateral do epistolar "O ventre Seco". Nos dois textos transcorre um mesmo conflito - cada qual a seu modo, um embate entre o narrador-personagem masculino e a figura feminina, esposa, amante, namorada adensado por um recurso estético de efeito tensional, o silêncio, verificado em diferentes registros, do tratamento dado à linguagem à proximidade temporal dessas produções (BERTÉ, 2007, p. 3).

"HM" relata um breve instante de rejeição. Um homem está em seu escritório, em meio à madrugada, quando sua mulher entra na expectativa de amor e afeto. Os olhos se cruzam sem se encontrar. Homologamente à "VS", a secura sobressalta a tensão subjacente. O título "ventre seco" é metáfora do desânimo, do fracasso, da derrota, da impossibilidade. Nesse diapasão, a incomunicabilidade acompanha estes dois textos. A imagem das trevas aparece como algo que toma a vida do casal. O homem é seco e cruel; mesmo achando que a mulher desabaria não diz qualquer palavra para tranquilizá-la. O desprezo pelo cônjuge está em “O velho” (V), mas lá o desprezado é o homem, reforçando a circularidade e as simetrias.

A mulher vem "em busca de amor" (NASSAR, 2016, p. 330; HM), tal como a amante em $C C$, que se rende a este sentimento ao voltar para a chácara após a briga. A busca de amor da mulher era, então, seu grito de socorro, a esperança, que Nassar procura relativizar e minorar. O impulso da vontade pede um caminho e um devir, mas o desfecho angustiante do texto não aponta um devir-progresso. As mudanças ocorrem em todas as direções, povoando as narrativas com confusos caminhos que se espalham na intimidade confinada dos personagens. A pletora de percursos torna-se mais notável quando o fluxo de consciência entra em ação, ganhando reforço também pela androginia dos casais, evidente em $C C$ e $L A$.

O homem experimenta um prazer cruel com o sofrimento da mulher: "fiquei um tempo sem me mexer, mesmo sabendo que ela sofria, que pedia em súplica, que mendigava afeto" (NASSAR, 2016, p. 331; HM). A mulher, mesmo humilhada, insiste. A humilhação e a submissão aparecem como identificação obsessiva do oprimido com a ordem que o reprime. A fórmula é: questionar a ordem reforça seu poder. Tendo em vista esse mecanismo, ao avaliar "HM" e "VS", notamos que não há saída pela dicotomia:

$O$ ventre seco foi escrito durante a época da ditadura militar no Brasil, época de uma literatura engajada, de contracultura, contra a lei - é proibido proibir -, posição que parece finalmente reforçar a lei, o bem e o mal, a mulher e o homem; época de uma dialética rigorosa, deixando entreaberta a questão: é possível uma outra saída? (LEMOS, 2010, p. 97). 
As dicotomias apontadas por Masé reenviam as dualidades do mundo social para o espaço restrito das relações conjugais, de modo que a equação entre o desejo e sua vazão repercutem tanto como libido social quanto como erogenização da intimidade dos casais, projetando na vida comum resquícios de uma história mais ampla da qual não é possível se abster. Remoto, o homem não deseja nenhuma troca com a mulher. O desencontro destes corpos sinaliza a difícil conjugação das diferenças, conquanto o desejo de cada um deles se extravia na sinuosidade do tempo de convívio. O desejo demanda correspondência, mas as investidas da mulher são vãs posto que o marido insiste em estancar o contato verbal ou corporal. A não efetivação deste desejo conforma uma angústia que vai se deslocando em melancolia e desespero, já que a repressão do desejo inaugura nela um espaço de indeterminação, um halo de solidão e tristeza.

Nesse caso, a vontade depende sempre de um outro, de um outrem, do contexto em si, no bojo da triangulação edipiana (MASOTTA, 1989). Por isso, a economia do desejo, considerando a psicanálise, se articula mediante uma negociação inconsciente entre o sujeito e seu ambiente, em suas relações sociais, de modo que é a própria subjetividade (o superego) que impõe limites à satisfação e ao gozo instintivos (Id), permitindo que o os desejos funcionem como pulsões (de vida e de morte) que mantêm as pessoas em busca, de modo que o desejo possibilita o próprio caminho. O desajuste entre o desejo e a capacidade de ser alcançado caracteriza a concepção cultural de Freud, uma referência que subjaz a (est)ética nassariana: “poética imbricada à psicanálise que se desenha no encontro com a literatura" (TARDIVO, 2011).

O embate entre vontade e moral perfaz os textos de Raduan. A vontade como devirsoberano e o contrato social como interdito constante e instransponível. À medida que a repressão barra a vontade transgressiva e violenta, o sujeito constrói suas máscaras sociais. Nesse caso, há uma vontade frenética e delirante, excessiva, um impiedoso apelo do corpo que confronta outros corpos. Como observado por Estevão Azevedo (2015), a obra de Nassar substancia na linguagem escrita uma corporeidade erótica. Suas palavras conferem densidade e complexidade às sutilezas cotidianas embotadas nas mais discretas formas e movimentos corporais, que produzem por si próprios a corporeidade das palavras, pois é justamente na linguagem e na expressão que residem a sexualidade e o erotismo:

o que está em cena na obra de Raduan é a tensão entre uma apologia da destruição da verdade e a defesa feroz da própria fala. Nisso reside uma afirmação categórica e violenta de uma virilidade à beira do colapso, potencializada tanto pela intensidade quanto pela precariedade. Esse protagonismo de corpo tem dois pilares. O primeiro, a relação de distanciamento dos textos com seu contexto histórico. Sua ficção considera 
um embate mais amplo: o de vontades de poder que se manifestam pela linguagem [...] O segundo pilar é o erotismo. Para o chacareiro, associar a verdade dogmática a mulher significa dotar esse inimigo conceitual de um corpo material, apto a estabelecer relações de poder e de prazer. É na imposição de uma fala que o vigor sexual pode ser reencontrado: a fricção dos discursos é tão ou mais erótica que a das peles (AZEVEDO, 2016b, p. 1).

Se a fricção das palavras é isomorfa ao atrito corporal, o movimento elíptico das narrativas ora atrai ora repele os protagonistas. $\mathrm{O}$ aprisionamento ao microcosmo do casal tornase ainda mais intenso quando é a atração, o contato e a proximidade que acabam provocando a rejeição e quando é o desprezo o que acaba gerando um magnetismo e uma fixação no sexo oposto. Ao final do conto a mulher arranca subitamente em direção à porta do escritório. A parada dela antes de sair, segundo o narrador, pode significar uma breve reflexão sobre tarefas cotidianas ou uma progressiva escuridão que se instalaria em seu ser a partir dali. Não sabemos o efeito causado pela repulsa do marido, se será ressignificada e esquecida ou se alcançará o patamar de trauma. Outrossim, é sabido que o descolamento entre desejo e objeto, que dinamiza a busca e o caminho constitui não só a flutuação do desejo, mas a indeterminação compulsória do sujeito, subsumido nas relações conjugais, familiares e sociais:

A psicanálise de raiz freudiana trabalha com a hipótese segundo a qual o homem
precisa ceder algum grau de satisfação para que haja civilização. No célebre texto $O$
mal-estar na cultura, Freud contrapõe a satisfação pulsional às exigências da cultura
[...] é sobre a brecha marcada pelo conflito entre satisfação pulsional e cultura que a
psicanálise vai se debruçar (TARDIVO, 2011).

Não por acaso, Gilbert Durand $(1988 ; 1996 ; 2012)$ reconhece em Freud um dos responsáveis por reabilitar a imaginação e os símbolos como formas de conhecimento. A psicanálise freudiana não só confere valor e dá visibilidade ao inconsciente como reintroduz os mitos e os sonhos na interpretação dos fenômenos humanos. O trajeto antropológico durandiano consiste, precisamente, na relação entre pulsões subjetivas e intimações objetivas, lançando os conflitos do microcosmo interior à complexidade da vida social. As criações simbólicas que decorrem deste dinamismo entre subjetividade e objetividade configuram o repositório randômico que é o imaginário, que reabilita a sensibilidade, as emoções e a imaginação como formas de conhecimento. Nesse caso, a operação analítica de separação, distanciamento e fracionamento da razão é cara ao regime diurno do imaginário, ao que é a própria teoria durandiana do imaginário que vem equilibrar e ajustar a prevalência da racionalidade com símbolos e arquétipos de ordem noturna.

As palavras breves e rudes de "Hoje de madrugada" dialogam com "O ventre seco", ao que os contos propiciam ao leitor um cenário seco e desertificado, no qual orbitam seres 
inconciliáveis e incomunicáveis, pesando nessa vivência uma torrente de sentimentos e sensações cuja vazão fica por conta do próprio leitor, à medida que estes contos mantêm em débito todos os elementos espaciais e temporais que explicariam as relações de aproximação e afastamento entre os personagens. Em razão desta dívida, Nassar coloca em um ringue ou em um tabuleiro jogadores e peças que se movem através de lances previsíveis e cristalizadas, nas quais a razão se abre a uma tempestade de imagens e símbolos cuja incursão das emoções no julgamento de outrem torna evidente a arbitrariedade do universo dos valores humanos.

Conforme observado por Lemos (2010), “O ventre seco" foi influenciado pelo "Tratado das paixões" de René Descartes ${ }^{41}$, baluarte do racionalismo. Composto por quinze tópicos enumerados, traz econômicos recados de um homem à sua amante. No conto os valores e comportamentos da mulher são gradativamente quebrados à medida que o narrador os contrapõe às contradições da vida, tornando o espaço literário da carta-depoimento uma disputa na qual somente a voz masculina é ouvida, embora seja possível ouvir a mulher, discretamente, em Um copo de cólera.

"VS" e $C C$ reconfiguram a racionalidade introduzindo a componente passional da vida, presente no desejo sexual, na fisiologia corporal e na arbitrariedade do poder, articulado como autoritarismo e como cólera. Nesse caso, a movediça zona das emoções, solidária do imaginário noturno, oscila entre a calmaria uterina e o terror da escuridão. Portanto, aquilo que fica à margem dos contornos solares da sociedade tanto povoa os sentimentos e as sensações corporais quanto pode derivar na explosão colérica, elemento que compõe a guerra. Segundo Bataille (2015), a violência primordial de onde emerge o erotismo quando não fruída em sexualidade, nas artes, na magia e nos rituais, quando não dispersada em delírio corporal e devaneio poético, acumula-se aflorando e propiciando a guerra. Justamente por ser perigoso e caótico é que o terreno das emoções e da imaginação foi tão combatido pela tradição iconoclasta do ocidente. Nesse caso, a deseducação nassariana recupera a sensibilidade na leitura e na fruição da vida. Em entrevista à Liliane Heynemann, Raduan indica:

talvez o personagem narrador em Um copo de cólera devesse ter informado aos eventuais leitores de seu relato que sua parceira, racionalista radical beirando quase o caricato, simplesmente ignorava o Tratado das paixões, de Descartes, esse representante maior do racionalismo, mas que, nada ingênuo, valorizava o concurso das emoções em sua teoria do conhecimento (NASSAR, 1992, p. 4).

\footnotetext{
${ }^{41}$ DESCARTES, R. "As paixões da alma”. In: Descartes: obras escolhidas. Tradução de: J. Guinsburg, Bento Prado Jr., Newton Cunha e Gita K. Guinsburg. GUINSBURG, J.; ROMANO, R.; CUNHA, N. (org.). São Paulo: Perspectiva, 2010.
} 
"O ventre seco" não só funciona como preâmbulo de $C C$, como pode ser visto como um apêndice, prólogo, epílogo da novela, posto que, aparentemente, tratam-se dos mesmos conflitos e dos mesmos personagens. Se em $C C$ os amantes não são nomeados, em "VS" a ênfase recai sobre a mulher, Paula (pequena, delicada). Raduan coloca o excluído em um não lugar, como é o caso de Ana em Lavoura arcaica. O feminino nassariano se investe em sensibilidade diante da razão científica, em paixão diante do discurso político, em corpo, em erotismo, em misticismo e sensualidade, em tudo aquilo que a razão tiraniza como falso e a religião imputa decadência. A personagem Paula de "VS" é a jornalista de $C C$, em que a suposta fragilidade feminina contrasta com o viciado rigor racional. Mediante ambiguidades e conflitos, Raduan vai reconquistando o demens no sapiens à medida que anuncia o universo dos valores como reino da arbitrariedade passional, sob os auspícios do imaginário da queda.

O descrédito pelo amor conjugal se manifesta em quase todos os textos nassarianos e expressa, também, a descrença no amor maior (da divindade cristã). Com a implosão do amor, Nassar também rompe o liame social e sua possibilidade de coesão espontânea: o mundo só se sustenta com a imposição da ordem. O narrador de "VS" pretende "turvar a transparência dessa água" (NASSAR, 2016, p. 340; VS). O amante recusa o equilíbrio das coisas porque não acredita na coerência do mundo. A conflitualidade inerente no primeiro item do conto, de apelo histórico e ancestral, se mostra como na problemática de $O$ mal-estar na civilização (FREUD, 1997): manipular e ser manipulado, viver em um mundo reduzido a interesses mútuos. Por outro lado, o narrador apela à sofistica quando se diz manipulado pela amante, enquanto o leitor, por sua vez, não verifica essa situação, dada a unilateralidade do texto.

$\mathrm{O}$ item 2 mostra a entrega feminina e o desprezo masculino. O narrador usa o corpo da mulher, mas depois dispensa seu mundo e suas preocupações. Por outro lado, esse mesmo narrador se considera usado pela moça, reforçando a ideia de manipulação forjada no item 1 . $\mathrm{O}$ homem finge-se desinteressado e indiferente, enquanto projeta seu ressentimento no quinto item: "é bastante tranquilo este depoimento, é sossegado" (NASSAR, 2016, p. 339; VS). Ainda no item 2, o narrador desresponsabiliza-se, recusando e desatando o nó que unia o casal, e se exime de obrigações ao insistir que não deve explicações à amante.

No terceiro item, o narrador despreza o dinheiro, o conhecimento e a sexualidade, compondo um exílio silencioso para fora do qual quer expulsar, em definitivo, a mulher. Contudo, ao dispensar a mulher, prescinde também das questões sociais nas quais ela esteve envolvida: "feminismo", "divórcio" e "descriminalização do aborto" aparecem no item 4, insinuando a orfandade da juventude e de suas causas, cuja procura de potência e realização 
incide recorrentemente em reiterar a ordem à medida que dicotomiza a realidade quando se coloca contra o status quo.

No item 5 o narrador rechaça a "precária superioridade" da mulher, que o chamava de "velho", ao criticar suas atitudes e opções pessoais. Cínico e simuladamente indiferente, o narrador quer se isolar do mundo. Segundo ele, Paula é uma amante que quer enquadrar o homem em seu mundo ideal. No sexto item o narrador questiona e relativiza o amor recusando, sobretudo, o afeto da amante e sua apologia a este sentimento. Na sequência, o item sete traz o questionamento das "ideias claras e distintas", em alusão ao racionalismo da mulher, sugerindo no lugar a confusão e a recusa, reforçando a intenção nassariana de desfazer a hegemonia da razão e romper com o dogmatismo da clareza. A crítica da razão asséptica segue-se no oitavo item, quando recorre novamente ao "chão movediço" dos valores para justificar o caráter primordial da verdade única, dos dualismos e certezas que limitam a experiência de compreensão e de vivência.

No item 9, o narrador a provoca pedindo-lhe que encontre um lugar para a paixão pelo obscurantista conservador, já que ela permanecia obcecada por ele, embora o criticasse constantemente. $\mathrm{O}$ corpo trai a ideologia: o tesão não obedece aos critérios de classe e grupo social, o tesão não se enquadra na norma, ele rompe a norma como transgressão de um corpo que jamais terá coerência ideológica porque o erotismo é espontâneo e imprevisível. O décimo item aponta o julgamento da amante, que pouco a pouco compôs no narrador a figura de um moralista. Não obstante, o que a moça chama de moralista, na perspectiva do homem, é apenas uma cínica indiferença diante de um mundo simulado. Da postura indiferente deriva o silêncio, conforme o qual este narrador recusa as "certezas", as "convicções" e os "redemoinhos virulentos" da moça, apontados no item 11.

O item 12 reitera a vontade irracional e a teatralidade do mundo posto que retira violentamente a compreensão de um ponto fixo, lançando a experiência de vida em uma jornada caótica e incoerente, de onde tanto a sensibilidade como a consciência são uma “degenerescência", vinculada ao arquétipo da queda. No treze o homem pede que a amante desapareça de seu ambiente por completo e que se resigne em esquecê-lo, apelando para a submissão feminina. A recusa, no item 14, amplia-se para abarcar os objetos pessoais da mulher, de modo que o narrador alega ter dispensado os "apetrechos" da "toalete" da moça na portaria com o zelador.

Tal como na novela Um copo de cólera, o desfecho de "O ventre seco" é edipiano. A mãe do narrador, no item 15 do conto-carta, seria descrita por Paula como a expressão do maligno: bruxa tramando nas trevas. O narrador, afinal, pede que sua amante o esqueça 
decididamente. A recusa entra em cena, como motivo potente nestes dois contos, alcançando cada elemento da mulher, distribuindo o ressentimento e o desprezo do narrador não só pelo relacionamento e pela pessoa com quem dividiu a vida, mas também pelos seus objetos, por suas ideias, por seu papel social, por seu contexto, seus amigos, suas preferências, em suma, tudo que compõe um cenário à volta da moça, descartando seu mundo por completo e com convicção.

\subsection{A FEMEAZINHA EMANCIPADA E O FASCISTÃO}

A novela Um copo de cólera (CC) é permeada pela atmosfera política que pairava no Brasil durante o Regime Militar. O tensionamento político daquele período investe na performance dos amantes os dualismos, as categorias e as características do contexto brasileiro durante os anos de chumbo. Não obstante, diversas referências ao período circulam lateralmente pela obra, como a repressão, a tortura, a disciplina, a vanguarda, a polarização, o tropicalismo, as novelas, o carnaval, o futebol, a imprensa alternativa, a censura, a pornochanchada, o Cinema Novo e as transformações econômicas e sociais pelas quais passava o país. Tais elementos vêm amalgamados na culpa, no ressentimento, no autoflagelo, no martírio e no calvário, na perversão, na malícia, na crueldade, na indiferença, na dependência, mobilizando uma miríade de emoções, sensações e ideias que explodem na cólera discursiva do picadeiro de um circo ou de um palco italiano cujos olhares e dedos estão, afinal, apontados para os espectadores que, estáticos em sua simplicidade, permanecem em seu invólucro espelhado protegidos pela intransponível quarta parede das referências de classes sociais.

Como em um zoológico abandonado, a sofisticação da discussão do casal burguês chama reiteradamente o "povo" para a conversa, enquanto a vivacidade e a curiosidade do casal de caseiros da chácara destacam a componente risível daquele espetáculo, como uma comédia sem importância, uma trivialidade assentável na qualidade de ridículo. A pujança caricata dos personagens centrais, flertando com o ufanismo e com a decadência, expõe o grotesco da classe média, confusamente situada no sustentáculo cultural da sociedade de classes.

Palavras como "camarim”, “plateia”, “palco”, “máscara”, “espetáculo”, “cena”, “ator”, "atriz", "performance" e "disfarce" sugerem a teatralidade a todo instante. O texto trata de um dia na vida de um casal que se entrega a uma convulsa discussão provocada por um acesso de cólera do homem que, ao ver um rombo na cerca viva originado pela ação das formigas, discursa violentamente contra a mulher, encontrando nela a imagem do mundo contra o qual vocifera com violência, sem esquecer que em sua explosão opera também uma implosão, ao que 
endereça desde o início a fala a si próprio, alimentando a gradação valorativa que Raduan dissipa e concentra em seus ritmos que versam sobre a condição humana no atravessamento entre o social e o individual.

A narrativa é composta por sete capítulos distribuídos de forma assimétrica. O cerne do texto é o capítulo seis, “O ESPORRO”, em que as tensões e angústias abafadas no silêncio das relações do casal dão lugar a uma violência irracional que atinge gradações exponenciais, indicando um movimento espiralado, que quanto mais cresce mais penetra fundo na condição humana. A explosão se alimenta do combustível mais eficiente: as contradições e ambiguidades do ser humano, emanadas e ancoradas no sinuoso e movediço edifício dos valores. Diante de timbres tão ferinos, o narrador e sua amante experimentam a vazão de uma lava espessa, um vômito que devolve ao mundo as "escrotas contradições" da religião, da política, da ciência, da família e da educação, recuperando na linguagem colérica o prazer singelo da expressão literária.

Os cinco primeiros capítulos, "A CHEGADA", "NA CAMA", "O LEVANTAR", "O BANHO" e "O CAFÉ DA MANHÃ", demandam a tranquilidade do cotidiano e da rotina, recuperando os rituais do casal e sua convivência conjugal. Todo o cenário vai sendo montado pelo narrador como preparação para suas atuações coléricas. Nesse caso, os capítulos desta obra conferem um caráter, ao mesmo tempo, iniciático e circular ao enredo, alcançando um carma que se repete como chaga e estigma na vida dos casais. Nos primeiros lances, homem e mulher partilham uma tensão silenciosa durante a chagada do amante à chácara. A jornalista o espera com os portões abertos, impaciente. Após as calculadas mordidas no tomate, o casal segue para o quarto, ela sempre em seu encalço. Na sequência, o chacareiro masturba-se ao lembrar das técnicas e estratégias utilizadas pelo casal em suas transas. Tratam-se de trechos em que o erotismo de Nassar carrega mais força - mesmo sendo constante, aqui e em toda a obra - na aplicação do "eufemismo" como recurso para colocar em cena a sexualidade e o sexo. Não obstante, em $C C$, é frequente o uso da prosopopeia, atribuindo ao discurso e às palavras as características de objetos e alimentos, alinhando vocabulários de diferentes estirpes para configurar as tessituras e nuances das diferenças do casal.

Com os corpos unidos após a noite de sexo, subsumidos pelos fluídos e odores sexuais em uma corda que os prende, ao levantarem pela manhã, jornalista e chacareiro engalfinhamse como espécies vegetais que convivem entre si altercando parasitagem e mutualismo. Seus corpos, embrutecidos e amaciados pela vertigem sexual da noite anterior refazem sua androgenia no lento deslocamento até o banho. No chuveiro, o corpo feminino que outrora foi manipulado e instrumentalizado durante a dança erótica agora conforma cabelos, peito, virilha, 
esquivando pelos e amplificando a ambiguidade entre ternura e tesão, escurecendo os limites entre os papéis de mãe e mulher. Essa mesma confusão, terna e erótica, revolve a triangulação edipiana, trazendo à cena pais e mães de ambos, minando o absolutismo racional enquanto arrefece o convívio, castrando e sustentando em um só tempo a masculinidade do homemgaroto. O desjejum vem como último suspiro de tranquilidade, distribuindo nos objetos da mesa o claustrofóbico clima de tensão que convive com a calmaria daquela propriedade rural.

A percepção do furo na cerca viva dá início ao jorro colérico do homem, que se ampara nas investidas e cutucadas da mulher e na plateia que se insinua em Mariana e Antônio, os caseiros. O "esporro" obedecerá ao mesmo ritmo sexual da cama, inflamando o discurso conforme a atuação de cada parceiro, de modo que são as curvas, pelos, tecidos, odores, fluídos, cores, gostos e movimentos do ato sexual que compõem a gradação da discussão: quanto mais se eleva e se inflama a palavra mais se penetra na carne, mais se investe no sombrio prazer com a dor alheia e com a dor própria.

Consequentemente, a métrica sexual ganha continuidade na verborragia do casal, de modo que os personagens que tomam conta de seus corpos durante o sexo, seus olhares, seus movimentos, suas decisões, suas posições ante cada movimento, tomam conta de seus argumentos e de suas técnicas discursivas. Além disso, durante o sexo o chacareiro menciona Deus e motivos cristãos elevando mais ainda o estertor de sua parceira, que não só goza na submissão como goza na contradição. É assim que a religião, a política e a sexualidade se fundem, tornando incisivos e densos os lances desta novela. Raduan converte em um só espaço a encenação da perversão sexual, da demagogia e das liturgias públicas. Assim, o tom se elava a cada página, amalgamando elementos díspares com sutis referências extraídas do imaginário brasileiro. O êxtase da narrativa é paralelo à empolgação de Nassar durante o processo de produção:

Eu lia alto. Quando eu estava escrevendo "Um copo de cólera" eu me divertia. Eu gargalhava. Ficava encenando as coisas, sozinho. Foram quinze dias tão loucos. Eu tinha uma chacrinha no que é a Granja Vianna [sic], que não tinha nada a ver com o que é hoje. Eu tinha acabado de reformar uma casa, ia morar lá. Mas eu ainda estava morando em São Paulo, pegava meu Volks e ia cedinho. A Raposo Tavares não tinha nada a ver com o que é hoje. Era uma estrada bucólica, verde, uma pista só, pouco trânsito. Isso em 68, 69. Eu tinha duas fitas da Joan Baez, lindas. Eu punha naquela altura. Às vezes eu dormia na chácara. Eu tinha um disco do Vivaldi e toda manhã acordava e tocava aquilo. O Vivaldi é muito melódico e alegre. E o solzinho da manhã... Era um tesão pelo mundo. Eu sentava e trabalhava das sete da manhã até a noite. Parava por cansaço, mental e físico, e sempre parava numa dificuldade. Mas estava tão tranquilo, porque sabia que depois ia ver aquelas novelinhas bobas da Globo, qualquer coisa assim, e no dia seguinte era acordar de cabeça fresca e continuar (NASSAR, 1995, p. 5). 
Vê-se que o jogo, a encenação e a brincadeira constituem a obra desde sua concepção. Tanto o é que suas gradações vão se constituindo em patamares cada vez mais elevados de exaltação. Durante o que o narrador chama de "preâmbulo", homólogo às preliminares do sexo, entre as páginas 225 e 252 (NASSAR, 2016; CC), os debatedores se tocam sem se prenderem, buscando os pontos fracos, avaliando os vacilos e desenhando uma estratégia de ataque. Assim, entre os olhares e o ato os jogadores tateiam com segurança os espaços da arena, friccionam suas peles, deixam entrevir suas mucosas, como em uma dança patética de acasalamento. Neste ínterim, o narrador compõe o modus operandi da racionalista, farejando seu modo de trabalhar e atirando restos sobre sua técnica tão higiênica.

O fim do "preâmbulo", das preliminares, é assinalado na passagem: "eu tinha de dar um fecha nessa farsa toda, já tinha ido muito longe c'o preâmbulo, bolinado demais a isca da pilantra, sentindo que faltava pouco pr'ela me rasgar a boca na sua fisga” (p. 252). A tensão erótica do trecho é intensa e a mudança de patamar fica patente, à medida que os debatedores penetram um no outro, cavoucando e cutucando as vicissitudes de ambos. A relação do "preâmbulo" com as preliminares fica patente no trecho: "era só fazer de conta que cairia na sua fisga, beliscando de permeio a isca inteira, mamando seu grão de milho como se lhe mamasse o bico do seio" (p. 236). A penetração segue, atingindo o "pico da liturgia" (p. 257), em que a velocidade e a intensidade aumentam em um frenesi, conquistando o gozo na explosão colérica da agressão física na página 265 . Na sequência, o ritmo vai caindo devagar, fazendoos desvencilharem um do outro e finalmente se separarem enquanto o chacareiro literalmente desaba retomando a confusa quietude uterina.

O silêncio que se segue após a fricção discursiva sinaliza o recomeço daquele ciclo, em que a ternura devolve à narrativa a calmaria do banho, quando o cuidado e o zelo femininos preenchem o corpo masculino de menino. O motivo materno e uterino se confirma pela emergência de um recomeço, balizado na repetição do nome do capítulo, "A CHEGADA", iniciado exatamente com a mesmas palavras, agora trazendo a jornalista como narradora, completando a circularidade da obra. Além disso, após a fricção dos corpos e das palavras, durante a discussão, prenuncia-se uma "gravidez", uma vez que a posição fetal do chacareiro se soma às menções anteriores das leis maternas de constituição familiar (p. 275), de onde reitera-se o retrato da família, como um destino a ser seguido, prenunciando, em forma e conteúdo, a narrativa de Lavoura arcaica (LA). 


\subsection{O QUE AS FORMIGAS ESCONDEM?}

A imagem da cerca-viva em Um copo de cólera (CC) remete à proteção e ao isolamento, como notado por outros intérpretes, como Lemos (2003) e Tardivo (2011). Não obstante, serve também de ornamento vegetal que traça os limites na zona fronteiriça entre luz e sombra, silêncio e cólera, incluído e excluído, indivíduo e comunidade, homem e mulher, família e sociedade, autenticidade e simulação, intelectual e homem comum. Ao mesmo tempo, atende à simbologia da mancha, que contamina por fora. Nesse caso, a contaminação ocorre através de uma fissura nos limites: "o buraco cavado pelas formigas na cerca viva de ligustro é o estopim da explosão colérica. $\mathrm{O}$ estrago causado pelas formigas corresponde à separação entre luz e trevas. As trevas da cólera o invadem” (PERRONE-MOISÉS, 1996, p. 71).

É justamente essa fissura, "a brecha larga desse desajuste” (NASSAR, 1996, p. 29), que a literatura nassariana expõe fartamente, como um estigma, uma ferida aberta situada na própria condição humana, na apreensão infantil dos valores humanos e nos desdobramentos do poder. Nessa direção, mediante essa transposição de limites constante e inevitável, a razão convive com as emoções em apenas um corpo, o progresso convive com o eterno retorno do mesmo, a ética convive com a vontade irracional e com a violência, e a dimensão estética da vida se impõe, pois, mesmo diante de tantas contradições, chagas e feridas. A cerca-viva mantém sua pulsação no ir e vir das formigas, entrevendo a beleza do ritmo tanto como o encanto da ornamentação vegetal. Resta-nos extrair o dinamismo simbólico que há nessas saúvas.

\subsubsection{Títeres}

A dinâmica dos casais deste nosso conjunto de textos opera a partir da manipulação recíproca, que se expande para todas as relações humanas. O mimetismo, o fingimento e a atuação apontam para ações simuladas, parte de um roteiro cujas cenas são premeditadas e realizadas com precisão e controle até o ponto em que a encenação se perde e os atores começam a improvisar, controlando seus corpos como títeres ou fantoches. Os operadores desses bonecos se revezam entre si na condução dos corpos femininos e masculinos, colocando em evidência a partilha de sentimentos que caracteriza as relações conjugais e sociais:

com o povo na boca, papagueando sua fala tosca, sem dúvida pitoresca, embora engrossando co'arremedo a sufocante corda dos cordeiros, exatamente como o impassível ventríloquo que assenta paternalmente os miúdos sobre os joelhos, denunciando inclusive trapaças com a sua arte, ainda que trapaceando ele mesmo ao esconder a própria voz (NASSAR, 2016, p. 257; CC, grifo nosso). 
Como em Autopsicografia de Pessoa, os atores fingem a dor que de fato sentem, apresentando no palco outras dores, percebidas como dores alheias pela plateia, tudo isso sobre o (des)controle de um dramaturgo, o escritor, que forja no leitor ainda uma outra dor. A confusão de sentimentos torna a condição humana inexprimível em sua completude, de modo que expressar nossas dores e contradições é um caminho sem fim e sem volta. Diante do mundo simulado, desistindo da verdade e de um ponto fixo, resta expressar a indignação com esse mundo, denunciar sua encenação e, se possível, se divertir com isso, ou, em outra direção, simplesmente silenciar a palavra e fazer falar o corpo, na linguagem sexual, na culinária, na botânica ou em outros pequenos prazeres da vida. Os títeres são cínicos, abusam da pedrapomes e estão por todos os lados, em todas as classes sociais e países. Nesse teatro de bonecos a principal técnica é a manipulação:

não tenho nada contra manipular, assim como não tenho nada contra ser manipulado; ser instrumento da vontade de terceiros é condição da existência, ninguém escapa a isso, e acho que as coisas, quando se passam desse jeito, se passam como não poderiam deixar de passar (a falta de recato não é minha, é da vida). Mas te advirto, Paula: a partir de agora, não conte mais comigo como tua ferramenta (NASSAR, 2016, p. 337; VS).

O narrador de "O ventre seco" entende a manipulação como uma condição de existência, ao que supõe ser possível escolher quem manipular e por quem ser manipulado. Ao denunciar o teatro de fantoches, o narrador não aponta a busca pela verdade e pela integridade como solução. Apenas expõe os mecanismos, técnicas e estratégias de manipulação, as descrever as fissuras e deslizes da atuação da amante e, ao fazê-lo, também torna evidente seus próprios expedientes de manipulação, seus próprios paradoxos. Tanto que, no item 4, em relação às questões feministas assume que "não tenho nada a ver com tudo isso" (NASSAR, 2016, p. 339; VS). Raduan assume postura similar ao tratar de minorias em entrevista: "não fale por um negro, se você não for negro. Só um negro conhece o tamanho da sua dor. Não fale por qualquer minoria, se você não pertencer a essa minoria" (NASSAR, 1996, p. 26). Entretanto, a perspectiva de não falar pelos outros sobrevive apenas no silêncio, já que a expressão sempre incorpora um outro; na linguagem persistem as relações humanas pois não se pode falar sozinho. Assim, Raduan, ao mesmo tempo que denuncia preconceitos ${ }^{42}$, o faz se queixando do uso desses preconceitos como plataforma política, entendido pelo narrador de "VS" como

\footnotetext{
${ }^{42}$ Segundo o escritor, em São Paulo, "o preconceito mais forte é contra os negros. Pergunto-me o que os anima para suportar tamanha dor". Na mesma entrevista, adverte que "o preconceito racial dos povos que estão por cima contra os povos que estão por baixo era próprio de um olhar que não incorporava a perspectiva histórica" (NASSAR, 1998, p. 6), reforçando as teses de "A corrente do esforço humano" (CEH).
} 
proselitismo, como adverte no item 3. No item 9, por sua vez, o narrador denuncia e recusa o mundo como representação: "fico espantado com este mundo simulado que não perde essa mania de fingir que está de pé" (p. 340).

Em "Hoje de madrugada" a atuação do casal é notável. Para tentar seduzir o marido, a mulher entra em seu escritório compondo um papel. Como atriz, busca a expressão corporal para imprimir no homem uma reação. A mulher escolhe um figurino, uma camisola transparente, projeta um "olhar perdido", entra no cômodo e se espreme no canto em silêncio. O homem responde sua investida com um áspero silêncio, evitando, inclusive, o olhar da esposa. O marido permanece impassível e imóvel com o lento andor da esposa até a mesa. Sua personagem não possui falas, apenas rubricas. O texto encontra o interlocutor por meio de um bloco de papel onde marido e mulher trocam mensagens, dando peso ao sinuoso espaço de comunicação entre o casal. O marido continua sua postura de desprezo: "não disse nada, não fiz um movimento, continuei com os olhos pregados na mesa” (p. 330). O homem, mesmo incitado pela esposa, recusa o contato. Em seu fluxo de consciência avalia a personagem decadente formulada pela esposa: "agora expunha a nuca a um golpe de misericórdia” (p. 331). O marido finalmente responde, recusando qualquer demonstração de afeto. Para se recompor e continuar no personagem "ela deitava o bloco na mesa com calma e zelo surpreendentes" (p. 331), simulando tranquilidade diante do desprezo do homem. A mulher desloca-se pelo espaço e tenta laçar o marido com seu corpo:

minha mulher deu a volta na mesa e logo senti sua sombra atrás da cadeira, e suas unhas no dorso do meu pescoço, me roçando as orelhas de passagem, raspando meu couro, seus dedos trêmulos me entrando pelos cabelos desde a nuca. Sem me virar, subi o braço, fechei minha mão no alto, retirando sua mão dali como se retirasse um objeto corrompido, mas de repente frio, perdido entre meus cabelos. Desci lentamente nossas mãos até onde chegava o comprimento do seu braço, e foi nessa altura que eu, num gesto claro, abandonei sua mão no ar. A sombra atrás de mim se deslocou, o pano da camisola esboçou um voo largo, foi num só lance para a janela, havia até verdade naquela ponta de teatralidade (NASSAR, 2016, p. 332; VS, grifo nosso).

A mulher disfarça, olha a janela sem nada ver, enquanto morde seus dentes de desejo e carência. A teatralidade decadente da esposa segue em uma nova investida: "não me surpreendi com o laço desfeito do decote, nem com os seis flácidos tristemente expostos, e nem com o traço de demência lhe pervertendo a cara" (p. 332). Na sequência, a mulher procura seduzir o marido pelos pés, tentando prendê-los aos seus no mesmo ritmo do capítulo "O LEVANTAR" de Um copo de cólera, mas na novela os dois amantes, envolvidos sexualmente, vão ao banho fundidos um ao outro. Em "HM" a separação emerge da rejeição sexual enfrentada pela esposa tornando vãos os apelos da mulher. Nesse caso, se em $C C$ e "VS" a atração sexual consegue 
persuadir os personagens masculinos, em "HM" esse artifício dá mostras de ter se exilado como possibilidade de comunicação e afeto, mediante o envelhecimento do casal. A mulher termina sua encenação com um movimento de arrancada seguido de uma parada enigmática sucedida, afinal, de sua saída definitiva do quarto.

O ambiente de atuação e simulação é evidente em $C C$. Enquanto a mulher segue o chacareiro com os olhos a todo momento, o homem finge que não nota. $\mathrm{O}$ amante protagoniza cenas em que expõe seus dentes e seus pés, que funcionam como símbolos de masculinidade e sexualidade: "comecei a comer o tomate, salgando pouco a pouco o que ia me restando na mão, fazendo um empenho simulado na mordida pra mostrar meus dentes fortes como os dentes de um cavalo" (p. 206). Ela, por sua vez, também simula indiferença, contorcendo-se em sua curiosidade. Os papéis são rapidamente assumidos, já nas primeiras páginas da obra. O homem é um machista indiferente, compondo uma figura de austeridade e arrogância. A mulher é apresentada por ele como amante submissa, desfrutando, por sinal, de um grande prazer em ser desprezada e açoitada: "sabendo acima de tudo que mais eu lhe apetecia quanto mais indiferente eu lhe parecesse" (p. 206). Os estereótipos de gênero somente se entrecruzam com a dicotomia entre a racionalidade da amante e a visceralidade do homem, mas se reforçam à medida que o homem permanecerá como violento e a mulher seguirá como paciente.

A estratégia do jogo, aqui, é sempre a mulher respondendo à iniciativa masculina, destacando também o elemento de passividade do estereótipo feminino. Nesse caso, os títeres são dirigidos pelo homem, com participações furtivas da amante: "por uns momentos lá no quarto nós parecíamos dois estranhos que seriam observados por alguém, e este alguém éramos sempre eu e ela, cabendo aos dois ficar de olho no que eu ia fazendo" (p. 208). Ao dar início ao ritual na intimidade do quarto, a indiferença do chacareiro se completa com seus movimentos calculados, "simulando motivos pequenos" durante as andanças pelo quarto, enquanto mostra à mulher os pés, metáfora terral da corporeidade e da sexualidade, em que se entrevê, também, o pênis do amante:

eu, sempre fingindo, sabia que tudo aquilo era verdadeiro, conhecendo, como conhecia, esse seu pesadelo obsessivo per uns pés, e muito especialmente pelos meus, firmes no porte e bem-feitos de escultura, um tanto nodosos nos dedos, além de marcados nervosamente no peito por veias e tendões, sem que perdessem contudo o jeito tímido de raiz tenra (NASSAR, 2016, p. 209; CC).

Enquanto a mulher vai ao banheiro, o amante se joga na cama, tirando suas roupas e compondo um retrato para surpreendê-la na volta. Quando a jornalista retorna, com seu "vulto ardente", já aparece imersa em sua personagem para o rito sexual: "de mansinho, muito de 
mansinho, se achegaria primeiro dos meus pés, que ela um dia comparou com dois lírios brancos" (p. 213). Na sequência, durante o despertar, o casal, pareado, traça os passos, vai em dueto para o chuveiro. Durante o banho os papéis se invertem, de modo que a mulher conduz o corpo do chacareiro, movimentando suas mãos com movimentos precisos, proporcionando conforto ao chacareiro e tentando seduzi-lo novamente em suas investidas. Nota-se que a jornalista se enquadra no papel da constante insatisfação feminina, tema caro à psicanálise. Ela tem o bastante, mas não o suficiente. Sua ausência, sua angústia e suas tensões desaguam em uma obsessão sexual, revertendo no sexo e na perversão toda corrente represada em seu racionalismo político e moral. Superado o momento do café da manhã, durante o "esporro", os atores passam da expressão corporal para as técnicas de fala e discurso, expostas e analisadas pelo fluxo de consciência do chacareiro que vai narrando cada movimento do debate. O palco se faz rapidamente com o estopim da cerca. $\mathrm{O}$ chacareiro, afinal, se prepara para entrar em cena:

entrei curvado pela porta do quartinho de ferramentas ali mesmo embaixo da escada, larguei lá os apetrechos que tinha carregado pra dar cabo das cortadeiras, mas, previdente, aproveitei a provisão das prateleiras pra me abastecer de outros venenos, além de eu mesmo, na rusticidade daquele camarim, entre pincéis, carvão e restos de tinta, me embriagar às escondidas num galão de ácido, preocupado que estava em maquilar por dentro as minhas vísceras, sabendo de antemão que não ia nisso nada de supérfluo (NASSAR, 2016, p. 229; CC, grifo nosso).

Passados os momentos de ensaio dos capítulos iniciais, o homem prepara seu personagem simulando suas verdadeiras dores, como quem se inspira em Stanislavski ${ }^{43}$ para subir ao palco. A jornalista prepara dona Mariana como plateia e o espetáculo começa. A disputa discursiva permeia também uma disputa estética, os atores concorrendo entre si para dominar a cena: “eu já puxava ali pro palco quem estivesse a meu alcance, pois não seria ao gosto dela, mas, sui generis, eu haveria de dar um espetáculo sem plateia” (p. 232), diz o chacareiro, pendendo agora para Brecht ${ }^{44}$. Trazendo dona Mariana e seu Antônio para a cena, o homem busca uma deixa para a explosão, um "tiro de partida". Elenca as possibilidades de participação da caseira com ares de diretor. O figurino aparece como "máscara" e a técnica

\footnotetext{
${ }^{43}$ De acordo com a perspectiva de formação do ator, em Stanislavski, a composição do personagem para atuação pode se fazer mediante o empréstimo de emoções, traumas e cenas pessoais do ator projetadas em outros sentimentos e sensações experimentados pelo personagem que deseja compor. Assim, para Stanislavski o ator pode reviver experiências pessoais traduzindo-as no desempenho do papel requerido.

${ }^{44} \mathrm{O}$ palco italiano, formato tradicional no teatro, é composto de três paredes, o fundo e suas duas laterais. Para Brecht, a quarta parede é aquela que fica entre os atores e a plateia. A ruptura desta parede significa, portanto, que os atores convocam a plateia para dentro das cenas, seja por sua presença física no próprio palco, seja demandando respostas do público que podem, inclusive, modificar o desfecho das cenas, a depender da intenção e da condução dramática. Assim, os espectadores acabam, desavisados, por se tornarem atores do espetáculo, em um prenúncio da própria linguagem da performance, retirando por completo a exigência de um palco.
} 
aparece como "ferramenta". As rubricas apontam a maneira como o diretor vai avaliando a atuação dos personagens, sem esquecer que está também em cena.

$\mathrm{O}$ diretor analisará recorrentemente as expressões corporais e a técnica dos atores. $\mathrm{O}$ corpo da jornalista recebe sua avaliação: “era inteligente a jovenzinha, e versátil a filha da puta, eu só sei que ela de repente levou as mãos na cintura, mudou a cara em dois olhos de desafio, os dois cantos da boca sarcásticos, além de esbanjar a quinquilharia de outros trejeitos" (p. 240). A avaliação técnica, por sua vez, surge em diversos momentos, por exemplo: "putíssimo comigo mesmo por ter passado de repente de um ataque curto e grosso à simples defensiva, propiciando ainda que ela, capciosa, acionasse com absoluta precisão o bote” (p. 245). O teatro oscila entre o palco e a arena, como a encenação transita entre a peça teatral e o debate político, dividindo e espalhando comentários entre réplicas e tréplicas de cada um. O homem forja na amante a imagem do travesti, enquanto ela forja no povo a imagem do palhaço:

o sujeito usa enormes conchas de borracha à guisa de seios, desenha duas rodelas de carmim nas faces, riscos pesados de carvão no lugar das pestanas, avoluma ainda com almofadas as bochechas das nádegas, e sai depois por aí com traços tão fortes, o cara consegue ser - embora se traia nos pelos das pernas e nos pelos do peito - mais mulher que mulher de verdade

todo cidadão tem o direito, claro, de meter duas rodelas de carmim nas faces, de arredondar a ponta do nariz numa bola vermelha, de pendurar no braço um pau grosso e torto à guisa de bengala, e de ajustar um chapéu-pituca, alto e pontudo, sobre a nuca, e feito isso, sair em praça pública fazendo graça (NASSAR, p. 246-7; CC, grifo nosso).

Percebe-se a disputa entre chacareiro e jornalista pela composição dos personagens. Mesmo mantendo adereços do figurino, cada um deles pensa em um conceito para a indumentária deste circo-carnaval, elevando ao lugar bem visível a inocente disputa por fantasias dos garotos em "Menina a caminho". O mimetismo da jornalista surge como um clown nefasto, pervertendo diabolicamente as imagens criadas pelo homem, em um riso colérico e voluptuoso que escancara as sutilezas da dramaturgia do chacareiro. Entretanto, a musicalidade não perde espaço no enredo: "tinha vibrado um diapasão e pinçado um tom suspeito, mas, como simples instrumentos - inclusive as inefáveis... - e já que tudo depende do contexto, que culpa tinham as palavras? existiam, isto sim, eram soluções imprestáveis” (p. 248).

Em outras ocasiões o texto pende para o épico: "Hosana! eis chegado o macho! Narciso! sempre remoto e frágil, rebento do anarquismo!", que convive com o tom profético, na epígrafe da obra: "ninguém dirige aquele que Deus extravia" (p. 203). E os personagens vão assumindo outros estereótipos, conforme a sucessão dos atos, replicando o "cadela" de "Menina a caminho" no "puta" (p. 265) e o "corno" em "bicha" (p. 264) e "brocha” (p. 273), ambos os 
desfechos acompanhados pela surra, reforçando a masculinidade violenta e a culpa que sucede a agressão tanto do chacareiro quanto de Zeca Cigano. Mas a violência e a indiferença do homem reforçam a submissão feminina, levando a jornalista a expressão corporal semelhante à esposa de "Hoje de madrugada", lançando mão do poder da vítima: "ela mantendo com volúpia o recuo lascivo da bofetada, cristalizando com talento um sistema complexo de gestos, o corpo torcido, a cabeça jogada de lado, os cabelos turvos, transtornados, fruindo, quase até o orgasmo, o drama sensual da própria postura" (p. 265).

\subsubsection{Professor}

Outro papel importante ocupado pelas figuras masculinas neste conjunto de textos é a posição de professor. Tanto Paula, em "O ventre seco", quanto a jornalista de Um copo de cólera seguem e imitam os personagens masculinos: "sempre atenta à dobra mínima da minha língua, assim como ao movimento mais ínfimo do meu polegar" (NASSAR, 2016, p. 341; VS). O roteiro que o chacareiro desenha em sua mente, "pensando nas artimanhas que eu empregaria (das tantas que eu sabia)" (NASSAR, 2016, p. 210; CC), momentos antes do sexo, é também o roteiro daquele preâmbulo tão calculado como a dinâmica rítmica da sexualidade. A superioridade masculina, no entanto, é confirmada antes e depois do esporro: "é este o canalha que eu amo" (p. 210), como o é a mestria com que o chacareiro conduz a jornalista. Uma pedagogia do ato sexual se investe na avaliação mútua:

\footnotetext{
me falando sobretudo do quanto eu lhe ensinei, especialmente da consciência no ato através dos nossos olhos que muitas vezes seguiam, pedra por pedra, os trechos todos de uma estrada convulsionada, e era então que eu falava da inteligência dela, que sempre exaltei como a sua melhor qualidade na cama, uma inteligência ágil e atuante (ainda que só debaixo dos meus estímulos), excepcionalmente aberta a todas as incursões, e eu de enfiada acabava falando também de mim, fascinando-a com as contradições intencionais (algumas nem tanto) do meu caráter, ensinando entre outras balelas que eu canalha era puro e casto (NASSAR, 2016, p. 212-213; CC).
}

É recorrente que o chacareiro faça um (auto)elogio à sua atividade professoral, apontando, por exemplo, o aprendizado da botânica, não deixando de estar imerso na atividade sexual. No terceiro capítulo ela o nomeia "meu mui grave cypresus erectus", ele a nomeia "trepadeirinha" (p. 315). Reivindica sua autoridade perante a amante de forma cínica e arrogante: "que tanto você insiste em me ensinar, hem jornalistinha de merda? que tanto cê insiste em me ensinar se o pouco que você aprendeu na vida foi comigo, comigo" (p. 240). Em outra oportunidade discute sua técnica durante a discussão avaliando que "não seria exatamente 
pedagógica a investida" (p. 243), reforçando sua validação como instrutor e condutor do debate das cenas.

A avaliação do amante após a agressão, orgulhando-se também de ter ensinado à mulher a comunicação através dos olhos, sugere sua submissão em seu fluxo de consciência: "você viu quantas coisas você aprendeu comigo?' ela haveria de dizer 'sim amor sim '” e se eu dissesse 'que tanto você insiste em me ensinar?' ela haveria de dizer 'esquece amor esquece’” (p. 270). E a posição autoritária do homem se confirma no trecho: "“e quem é o macho absoluto do teu barro? e ela fidelíssima responderia "você amor você"” (p. 270). A submissão da mulher no transe sexual confirma a postura do amante como professor. Porém, na sequência da humilhação e do sacrifício que ele faz a jornalista passar, cai derrotado pelas memórias e pela austeridade dos valores familiares e ancestrais, verdadeiros professores que, mobilizando a face terrífica do tempo, conduzem o gado ao poço, submetendo não só a jornalista na posição de esposa como o chacareiro na posição de marido: "sempre lúcida a mão maciça que nos conduzia" (p. 275).

\subsubsection{Saúvas}

Em "Menina a caminho", toda a agitação da cidade em torno da fofoca relacionada ao filho do seu Américo sugere um fervilhamento, que é uma das imagens que constelam como símbolos teriomórficos, a animalidade que um imaginário solar busca combater. Esse fervilhar é um princípio de combustão, demandando em uma transição mais intensa a matéria do fogo. Pensando com Durand (2012), há no fogo a possibilidade de contaminação e purificação. Naquele conto, é a contaminação que fica mais evidente, demandando o símbolo da mancha: “a representação da mancha está na zona cinzenta de uma infecção quase física que aponta para uma ignomínia [indignité] quase moral" (RICOEUR, 2015, p. 51). O aspecto objetivo de contaminação vai-se transmutando em questão moral. Os citadinos são seres tomados, então, pela maldade e pelo preconceito, estranhos à menina, que vai testemunhando as cenas num crescendo de agitação, a cada nova cena vai aumentando a tensão, a violência verbal e a ameaça de violência física.

Conservemos do formigamento apenas o esquema da agitação, do fervilhar (grouillement). [...] é este movimento que, imediatamente, revela a animalidade à imaginação e dá uma aura pejorativa à multiplicidade que se agita. É a este esquema pejorativo que está ligado o substantivo do verbo fervilhar (gmuiller), a larva. Para a consciência comum, todo inseto e todo verme é larva (DURAND, 2012, p. 73-74). 
O fervilhar, como ameaça, liga-se à mancha, de modo que procura uma brecha para contaminar os espaços. Uma vez contaminado, o sujeito ou o espaço são tomados pela angústia e pela tensão das divergências morais, distribuídas também nos corpos, nos objetos e no cenário ao redor. Além disso, o objeto corrompido, uma pessoa, uma cidade, uma situação, podem precipitar em explosão, como ocorre na surra de Zeca Cigano, em "Menina a caminho", e na discussão de Um copo de cólera, desde que a agitação resulte em combustão. Por outro lado, essa mesma explosão ocorre quando surgem nas narrativas o vômito. De um lado a precipitação aérea do debate, de outro a projeção aquosa da golfada.

O tensionamento e o desconforto das narrativas nassarianas giram em torno de uma questão moral, de modo que convivem o silêncio angustiante com o fervilhamento tenso das fofocas. Esse burburinho também aparece em "Aí pelas três da tarde”, quando os parentes cochicham em torno da performance do jornalista, em "Mãozinhas de seda", mediante o trocatroca dos intelectuais, e em "Menina a caminho" e "O velho", na fofoca que toma conta das cidadezinhas. Tanto o silêncio angustiante quanto o fervilhamento tenso podem incorrer no jorro colérico do debate ou na vertigem do vômito. Em "Monsenhores" o que precipita são "os pingos que caíam no assoalho" (NASSAR, 2016, p. 397; M), em "Hoje de madrugada" não há vazão, a tensão e a angústia permanecendo no ar, já "O ventre seco" e Um copo de cólera apresentam, efetivamente o jorro colérico, impresso da potência discursiva, na explosão sexual, no arroto, no vômito, na agressão, embora toda a dispersão e expressão não sejam suficientes para extinguir a angústia e a tensão, que recobrem os ambientes no instante seguinte, transmutando a mancha na culpabilidade, cuja recorrência implica na condição humana como danação: estamos aprisionados no mundos dos valores, mediante o contrato social.

A dubiedade dos objetos é amplamente explorada nas narrativas nassarianas, de modo que é a própria cisão múltipla das matérias corporais que implodem a razão asséptica. Por isso, sua deseducação implica em fazer ver a miríade de possibilidades simbólicas que cada objeto, cada situação e cada história guardam. Os dedos, por exemplo, tanto complementam o fervilhar, de modo que sugerem apontar para o bode expiatório, em sinal de julgamento e condenação, quanto seu uso no ato sexual, perfazendo uma ligação subterrânea entre o enredo das crises morais e os rituais da cama: "eu, fechando minha mão na sua, arrumava-lhe os dedos, imprimindo-lhe coragem, conduzindo-os sob meu comando aos cabelos do meu peito, até que eles, a exemplo dos meus próprios dedos debaixo do lençol, desenvolvessem por si sós uma primorosa atividade clandestina" (NASSAR, 2016, p. 210; CC). O paralelo se completa, ao que os dedos são apontados enquanto a língua vocifera, ambos imersos na cena sexual: "ela não teve o bastante, só o suficiente, eu pensava, por isso já estava lubrificando a língua viperina 
entorpecida a noite inteira no aconchego dos meus pés e etcétera" (p. 231). Por outro lado, são estes mesmos dedos que traçam carinhos no chacareiro durante o banho.

O chacareiro, em sua recusa, deseja a imobilidade, quer o ponto fixo onde possa circular apenas a intimidade das coisas mínimas do cotidiano. O furo na cerca mostra que esse isolamento nunca será total, de modo que o externo sempre convive com o interno, a sociedade sempre influencia o indivíduo, outras pessoas sempre influenciam os casais, o passado sempre estará vivo e não há como recusar, absolutamente, senão na morte. Assim, lidar com as formigas é lidar com um inimigo invencível: "puto com essas formigas tão ordeiras, puto com sua exemplar eficiência, puto com essa organização de merda que deixava as pragas de lado e me consumia o ligustro da cerca viva" (p. 228). As formigas veem de todos os lados, de modo que, enquanto o homem violenta as saúvas com formicida, a jornalista começa um burburinho com a caseira: "ela e a dona Mariana, nessa altura, estavam de conversinha ali no pátio que fica entre a casa e o gramado" (p. 228).

Outra faceta das formigas na narrativa será sua habilidade de ataque, sendo analisada a cada movimento pela consciência do narrador: "eu confesso que essa me pegou em cheio na canela" (p. 229). Em outro momento lamenta: “eu só sei que essa foi no saco" (p. 234). O fervilhamento, portanto, é transposto dos insetos rompendo a cerca-viva para "um bate-boca de reconfortante conteúdo coletivo" (p. 235), no qual cada espaço, cada um dos furinhos do formigueiro social é uma oportunidade de contaminação, cujos contornos são expostos como aberrantes paradoxos. Cada elemento contraditório é uma oportunidade de cutucar o corpo social, cujas bases, empregando a metáfora do edifício, são movediças, podendo ruir a qualquer momento. Por isso, os mesmos dedos que vão na performance sexual, propiciando o torpor, são empregados nos carinhos, levando ao aconchego, e são apontados para os desajustados, inquirindo-os, mas não deixam de, na fofoca e na provocação, cutucar cada brecha e cada ferida, sendo os sentimentos, as memórias e as emoções os terrenos onde dedos, mãos e bocas se insinuam, amalgamando sexo, carinho, política, família e sociedade em um só tecido agônico e fervilhante.

Em "O ventre seco", a cólera e o ressentimento derramados pelo narrador estão endereçados ao fervilhar de Paula, apontando dedos para o amante e para sua mãe, idosa que, supostamente, a mulher desconhecia o parentesco com o homem. Nas palavras do depoente, Paula chamava a senhora de "a velha aí ao lado", a "carcaça ressabiada", "o pacote de ossos", "a semente senil", "aquele ventre seco", "bruxa velha, preparando poções para envenenar nossas relações" (NASSAR, 2016, p. 343; VS). Por outro lado, a jovem mulher também compôs, nas palavras do narrador, um retrato do seu amante: "fazendo deste meu canto o ateliê 
do desenhista que ia no dia a dia emendando traço com traço, compondo, sem ser solicitada, o meu contorno, me mostrando no final o perfil de um moralista (que eu nunca soube se era agravo ou elogio)" (p. 341), perfazendo um papel avaliado em CC como "polícia feminina" (NASSAR, 2016, p. 256; CC) e incluindo no fervilhar a patrulha ideológica: “cruzando os braços, você seria conivente, mas vejo agora que isso é muito pouco, como agente é que você há de ser julgado" (p. 247).

O fervilhar, cuja imagem em $C C$ está muito ligada às formigas, em "Menina a caminho" aparece ligado aos ratos, no bar da esquina, contemplando e multiplicando a figura do Zé Povinho, a quem a jornalista cede a palavra. Em um contexto de ditadura e repressão, a abertura se insinua como tribunal popular: "não é comigo, solene delinquente, mas com o povo que você há de se haver um dia" (NASSAR, 2016, p. 256; CC). Contudo, o argumento da amante é contraposto pelo cinismo do chacareiro, recuperando a circulação de poder e violência no fervilhamento das fofocas e julgamento, de modo que são os fracos que aplaudem o forte:

\begin{abstract}
o povo nunca chegará ao poder! não seria pois com ele que teria um dia de me haver; ofendido e humilhado, povo é só, e será sempre, a massa dos governados; diz inclusive tolices, que você enaltece, sem se dar conta de que o povo fala e pensa, em geral, segundo a anuência de quem o domina; fala, sim, por ele mesmo, quando fala (como falo) com o corpo, o que pouco adianta, já que sua identidade jamais se confunde com a identidade de supostos representantes, e que a força escrota da autoridade necessariamente fundamenta toda 'ordem', palavra por sinal sagaz que incorpora, a um só tempo, a insuportável voz de comando e o presumível lugar das coisas; claro que o povo pode até colher benefícios, mas sempre como massa de manobra de lideranças emergentes (NASSAR, 2016, p. 257; CC).
\end{abstract}

O povo, quando aponta seus dedos e suas línguas, o faz sob influência das narrativas dominantes, quando se identifica com o opressor operando a ideologia burguesa (Marx). O oprimido não deseja combater seu opressor e, na maior parte das vezes, sequer tomar o seu lugar, mas reconstituir a violência repressiva nas pessoas a sua volta. Assim sendo, a emergência do corpo nos textos nassarianos emana essa voz popular, embora as referências eruditas e a sofisticação do discurso distanciem as narrativas da cultura popular. Essa contradição atravessa, portanto, a forma da literatura nassariana, de modo que é no próprio fervilhamento intelectual que os excluídos de Raduan ganham força, retomando a ideia de "A corrente do esforço humano", segundo a qual é legítimo que os excluídos se apropriem das referências dos dominadores redirecionando-as aos seus interesses, afinal, para a ilustração e apoteose dos grandes impérios culturais concorreram anônimos sem voz e com braços trabalhadores. Ciente desse paradoxo, Nassar o reintroduz, recursivamente e a todo instante, 
pondo em evidência a gradação necessária que convém à assunção de referências sofisticadas para empoderar o homem comum.

Embora o chacareiro exponha a jornalista como farsante, fantoche, ele também usa em seu expediente a voz do povo, a começar por se considerar excluído e oprimido por sua história pessoal. Aquilo que o amante condena em sua parceira guarda proporcionais simetrias com suas próprias contradições, ao que o chacareiro aponta que o mínimo a fazer é reconhecer essas ambiguidades: "e vendo o calor, sacro e obsceno, fervilhando em sua carne eu poderia dizer 'mais cuidado nos teus julgamentos, ponha neles um pouco desta matéria ardente"” (p. 270).

Em outra direção, diante do fervilhamento e da crescente ebulição da discussão, constantemente o chacareiro aponta tremer, indicando seu vacilo, seu medo e suas idiossincrasias. O homem, afinal, ao bradar contra o julgamento da jornalista, também julga e condena, personificando na parceira o fervilhar: "tinha avaliado mal o seu tamanho, não chegava sequer a nanica, era um inseto, era uma formiga" (p. 274).

Finalmente, percebemos que as formigas, para o narrador-personagem, são o burburinho das fofocas, o julgamento das pessoas, a linchamento dos excluídos pelo povo, a censura, a patrulha ideológica, a folha de jornal estampando e divulgando a vida privada e violência do cotidiano. Esses insetos nada escondem. São apenas uma espécie característica na ecologia alquímica da natureza, que a agraciou com a eusocialidade (WILSON, 1998), fenômeno ecológico, conforme o qual as formigas, as abelhas e alguns outros insetos são naturalmente sociais, tal como o é o homem, um ser social (Aristóteles). Segundo o ecologista Edward O. Wilson, para configurar eusocialidade concorrem três fatores: sobreposição de gerações, cuidado parental e divisão de castas. Estes três aspectos se insinuam em Um copo de cólera, de modo que a animalidade do ser humano é recuperada na austeridade dos valores familiares e ancestrais, na repetição dos dramas familiares e conjugais e nas diferenças sociais.

\subsubsection{A recusa e o espelho}

O conto "O ventre seco" é como um manual da recusa: 1) "não conte mais comigo como tua ferramenta"; 2) "não te devo explicações"; 3) "deixe este obscurantista em paz"; 4) "não quero te governar"; 5) "não gosto de gente"; 6) "tenho todas as medidas cheias dos teus frívolos elogios do amor"; 7) "farto também estou das tuas ideias claras e distintas"; 8) "a razão é muito mais humilde que certos racionalistas"; 9) “pense uma vez sequer, Paula, na tua estranha atração por este 'velho obscurantista', nos frêmitos roxos da tua carne, nessa tua obsessão pelo meu corpo"; 10) "estou falando da cicatriz sempre presente como estigma no rosto dos grandes indiferentes"; 11) "já cheguei a um acordo perfeito com o mundo: em troca do seu barulho, 
dou-lhe o meu silêncio"; 12) "encontrei, Paula, esquivo, o meu abrigo: coração duro, homem maduro"; 13) "desempenhe mais este papel: o de mulher resignada que sai de vez do meu caminho"; 14) "teu baby-doll, teus chinelos, tua escova de dentes, e outros apetrechos da tua toalete, deixei tudo numa sacola lá embaixo, é só mandar alguém pegar na portaria com o zelador"; 15) "se acaso amanhã teus amigos quiserem saber a meu respeito. Você pode dispensar 'a ridícula solenidade da velha', mas não dispense o seu irrepreensível comedimento, responda como ela invariavelmente te responderia: "não conheço esse senhor"” (NASSAR, 2016, p. 337-344; VS).

As narrativas nassarianas recusam com severidade e entusiasmo tudo e todos, mas não recusam, afinal, a vida, de modo que seus personagens e enredos sobrevivem em suas frenéticas tentativas de transmutação dos valores, em sua performance colérica. Da demolição dos ídolos e dos valores, restam apenas estilhaços, que em suas superfícies cortantes seguem atravessando os corpos, seguem impingindo na linguagem a expressão dos excluídos e os complexos mecanismos de exclusão.

Primeiro. Usar e ser usado é uma condição de existência, cabendo a cada qual apenas a limitada escolha sobre quem usará e por quem será usado. A manipulação se dá pela linguagem, de modo que as expressões corporais e verbais ratificam posições e constituem identidades, perfazendo lugares de fala que se dissipam cotidianamente nas relações humanas e historicamente nas relações sociais, políticas e econômicas. Segundo o chacareiro de $C C$, "ninguém, pisando, estava impedido de protestar contra quem pisava, mas que era preciso sempre começar por enxergar a própria pata, o corpo antes da roupa, uma sentida descoberta precedendo a comunhão" (NASSAR, 2016, p. 236; CC). Nesse caso, como em "A corrente do esforço humano", ninguém está livre do pecado original, as relações de poder, de modo que só resta à ética nassariana impor uma linguagem intensa que recuse um mundo simulado, sem com isso recusar que é também essa linguagem uma simulação, tomando como direcionamento apenas a singela expressão dos paradoxos humanos: "eu, o quisto, a chaga, o cancro, a úlcera, o tumor, a ferida, o câncer do corpo, eu, tudo isso sem ironia e muito mais, mas que não faz da fome do povo o disfarce do próprio apetite" (NASSAR, 2016, p. 261; CC). Ou ainda, em Lavoura arcaica: "requinte de saciados testar a virtude da paciência com a fome de terceiros" (NASSAR, 2016, p. 113; LA). Por isso, cabe ao leitor escolher. Diante do troca-troca dos intelectuais, das hierarquias geracionais de poder na cidadezinha, dos dramas conjugais, da corrupção, da miséria e da violência, o que resta e sustenta a vida, apesar do universo nassariano, é a beleza do pior dos mundos. 
Segundo. As satisfações, as explicações e as justificativas para nossas ações são vãs, de modo que "atenções", "presentes", "pessoas" e até mesmo o "corpo" que a amante entrega ao narrador de "VS" são utilizados à frente para cobrar responsabilidades: "não quero discutir os motivos da tua generosidade, me limito a um formal agradecimento, recusando contudo, a todo risco, te fazer credora que pode ainda chegar e me cobrar: "você não tem o direito de fazer isso"” (NASSAR, 2016, p. 338; VS). A cobrança surge, também, quando o chacareiro, já tirado a máscara, imiscuído de suas tenebrosas acusações na libidinosa sedução que recai sobre a mulher, finalmente a recusa depois de usá-la e depois de simular uma conciliação: "você não é gente' ela disse saindo do seu torpor 'você não é gente' [...] 'você não é gente, você é um monstro!' [...] 'você é um monstro, eu tenho medo de você'”, (NASSAR, 2016, p. 272; CC). As histórias pessoais, conjugais e familiares consumam perigosos compromissos, que também permeiam as histórias dos povos e das nações, de modo que a recusa e o isolamento são maneiras de rechaçar e se distanciar dessas responsabilidades:

me sinto hoje desobrigado, é certo que teria preferido o fardo do compromisso ao fardo da liberdade; não tive escolha, fui escolhido, e, se de um lado me revelaram o destino, o destino de outro se encarregou de me revelar: não respondo absolutamente por nada, já não sou dono dos meus próprios passos, transito por sinal numa senda larga, tudo o que faço, eu já disse, é pôr um olho no policial e outro nas orgias da clandestinidade (NASSAR, 2016, p. 253; CC).

O inconveniente de ter nascido coloca os personagens coléricos de Nassar, sobretudo o chacareiro (Um copo de cólera) e André (Lavoura arcaica), em uma condição de recusa e abstenção, ao notarem a implacabilidade do destino e a impossibilidade da transmutação de valores. Diante do caráter trágico da existência, estes seres se fecham em suas ilhas, vivendo uma confinada espera, conquanto desfrutam de prazeres simples, na falta de um mundo à sua imagem e semelhança. Nessa direção, a não aceitação e os sentimentos não correspondidos, inerentes às relações humanas, provocam no chacareiro tanto quanto em André o sentimento de indiferença e indignação diante da ordem, como se as coisas tal como se dão fossem, desde sua concepção mais tenra, absolutamente erradas, condicionando a realidade à sua maneira:

já disse que a margem foi um dia meu tormento, a margem agora é a minha graça, rechaçado quando quis participar, o mundo hoje que se estrepe! caiam cidades, sofram povos, cesse a liberdade e a vida, quando o rei de marfim está em perigo, que importa a carne e o osso das irmãs e das mães e das crianças? nada pesa na alma que lá longe estejam morrendo filhos (NASSAR, 2016, p. 255; CC).

A mesma recusa e o mesmo recuo aparece quando, em $L A$, André percebe que não será correspondido pelo amor de Ana: "vou cruzar os braços quando todos se agitam ao meu redor, 
dar as costas aos que me pedem por socorro [...] não tive o meu contento, o mundo não terá de mim a misericórdia; amar e ser amado era tudo o que eu queria, mas fui jogado à margem sem consulta, fui amputado" (NASSAR, 2016, p. 141; LA). Dentro das famílias, assim como nas relações conjugais, há sempre assimetrias de poder, pois o afeto se distribui de maneira diversa e assimétrica, pendendo ora para uns, ora para outros, criando cisões, diferenças e ressentimentos, que em hora e contexto adequado serão cobradas, o que contempla o sexto item de "O ventre seco".

Terceiro. O narrador-depoente imprime um compromisso consigo próprio: economizar rigorosamente seus tempos e seus espaços. Abster-se do uso desnecessário de riquezas, desvincular-se de buscar conhecimento e estar informado e, enfim, desistir de construir um relacionamento amoroso e sexual. Com isso, fica implícito que aplicará apenas o necessário em cada um desses campos, vivendo apenas daquilo que satisfaz o homem comum. Ao se agarrar às bases da vida, decidido ao recolhimento e ao silêncio, imprime na amante a imagem de conservador, mas sua voz rarefeita e o absenteísmo o fazem obscurantista, pois, tendo em vista toda a agitação em torno das mudanças sociais pretendidas pela parceira, recorre ao eterno retorno do mesmo para identificar que, mesmo havendo mudanças, a "corrente do esforço humano" as traduz em novas assimetrias e novas prisões, já que não há ordem que se sustente sem valores e não há valores que não gerem excluídos. Já que os fundamentos dos valores são obscuros, persiste o mistério das relações humanas, que à luz do pensamento binário e da razão asséptica se mostra como conservadorismo e traição. Na atmosfera de Um copo de cólera a patrulha ideológica, a razão de esquerda da jornalista - dialogando com o Regime e com a literatura engajada - compraz o chacareiro em fascista-trapaceiro:

você não passa, isto sim, é de um subproduto de paixões obscuras, e toda essa algaravia, obsessivamente desfiada, só serve por sinal pra confirmar velhas suspeitas... aqui com meus botões, aberração moral é sempre cria de aberrações inconfessáveis, só pode estar aí a explicação dos teus 'caprichos'... além, claro, do susto que te provoco como mulher que atua... e quanto a esse teu arrogante 'exílio' contemplativo, a coisa agora fica clara: enxotado pela consciência coletiva, que jamais tolera o fraco, você só tinha de morar no mato; em favor do nosso ecologista, será contudo levado em conta o fato de não ter arrolado a poluição como justificativa, imitando assim os mestres-trapaceiros que - pra esconder melhor os motivos verdadeiros - deixam que os tolos cheguem por si mesmos às desprezíveis conclusões sugeridas pelo óbvio, um jogo aliás perfeito e que satisfaz a todos: enquanto os primeiros, lúdicos, fruem em silêncio a trapaça, os segundos, barulhentos, se regozijam com a própria perspicácia; mas não é este o teu caso: trapaceiro sem ser mestre, o que devia ser escondido acabou também ficando óbvio, e o tiro então saiu pela culatra, pois só podia mesmo ser este o teu 'destino': viver num esconderijo com alguém da tua espécie - Lúcifer e seu cão hidrófobo... que pode até dar fita de cinema... há-há-há... um fechando os buraquinhos da cerca, o outro montando guarda até que chegue a noite, os dois zelando por uma confinadíssima privacidade, pra depois, em surdina... muito recíprocos... entre arranhões e lambidinhas... urdir com os 
focinhos suas orgias clandestinas... há-há-há... há-há-há... há-há-há... me dá nojo! (NASSAR, 2016, p. 259-260; CC, grifo nosso).

A citação contempla a magnitude dos paradoxos e das obscenidades da classe média, a quem a novela dirige uma crítica indireta. A promiscuidade do poder confere à política uma componente sexual, conquanto investe a atividade intelectual e científica de um manto de obscuridade sob o qual se guardam supostas certezas, verdades incontestáveis:

Obsceno é toda mitificação. Obsceno é dar um tamanho às chamadas grandes individualidades que reduz o homem comum a um inseto. Obsceno é não fazer uma reflexão pra valer sobre o conceito de mérito, dividindo tão mal o respeito humano. Obsceno é prostrar-se de joelhos diante de mitos que são usados até mesmo como instrumento de dominação. Obsceno é abrir mão do exercício crítico e mentir tanto (NASSAR, 1996, p. 34, grifo nosso).

Quarto. Por outro lado, em "O ventre seco", o narrador recusa a liberdade e recusa o progresso moral baseado na razão, reintegrando a reivindicação da juventude na afirmação egóica do adolescente, quando aquilo que foi recalcado retorna em confronto com a autoridade paterna, flertando novamente com a psicanálise. Nesse caso, o desenvolvimento "normal" da psique implicaria na aceitação da figura paterna, uma vez que o assassinato do pai da horda primitiva leva a um remorso subsequente (MASOTTA, 1989). Pode-se ver, além da necessária distinção entre as posições do autor e as posições de seus personagens, que há uma indignação no universo nassariano, uma revolta que procura dar voz aos historicamente marginalizados, mas que, desde já, pressente que os gritos e gemidos dos desesperados e oprimidos, se é que desejam gritar e gemer, acabam por reforçar a ordem e reconstruir a autoridade paterna do Estado e dos "donos": "no abuso do poder, não vejo diferença entre um redator-chefe e um chefe de polícia, como de resto não há diferença entre dono de jornal e dono de governo, em conluio, um e outro, com donos de outros gêneros" (NASSAR, 2016, p. 256; CC).

Quinto. Para minimizar a participação na promiscuidade do poder, o narrador-depoente de "O ventre seco" admite prescindir de gente, mas sobretudo de "gentes maravilhosas". Assim como o chacareiro de $C C$ (p. 258), o amante de Paula recusa o próprio convívio humano: "não gosto de gente, para abreviar minhas preferências" (p. 339). Transpondo a recusa de convívio para a reclusão do escritor, em entrevista, Raduan Nassar sintetiza sua deseducação com a descrença no progresso moral. Ao ser perguntado se ele, autor, não gosta de gente, responde:

não é o meu caso. Eu não morro de amores pela espécie. Se você quer saber agora o autor o que pensa, um pensamento nada revolucionário, não diria propriamente que fosse conservador também, eu acho que o homem é uma obra acabada. Pode estar diferente hoje, adquirir conhecimento, criar as maquininhas, voar pelo espaço, mas eu 
acho que ele é uma obra acabada. Eu não aposto no aprimoramento da espécie, eu não aposto nisso. Isso talvez tenha até a ver com o meu desinteresse pela literatura de um modo geral. E aí talvez a minha náusea em torno de toda produção cultural, porque eu não aposto muito nisso, se o objetivo é achar que a espécie vai melhor com isso (NASSAR, 1995, p. 5).

Sétimo. Nosso narrador-depoente recusa uma suposta ideia universal da história humana, o "propalado arranjo universal" (NASSAR, 2016, p. 340; VS). O amante se refere a explicações monolíticas para os conflitos e para as questões humanas, como o fazem os conservadores, defendendo a família e a propriedade como tradições supostamente ancoradas nos momentos primevos da história, questões que emanariam de uma suposta natureza humana. Por outro lado, marxistas e progressistas de toda ordem supõem a superação dos conflitos históricos mediante um processo revolucionário, um telos que condiciona a realidade presente a este devir inalcançável. Sem falar nas inúmeras manifestações do pensamento uno, como o é o cristianismo, como o são os regimes de exceção etc.

Recusar uma visão universal da realidade e da história coloca o narrador como alguém que busca a terceira via, quando não se comporta como um verdadeiro niilista, um grande indiferente (itens 10 e 11). Ao recusar a visão universal, recusa também a atitude daqueles que a utilizam como justificativa: "não há nada que esteja mais em moda hoje em dia do que ser fascista em nome da razão" (NASSAR, 2016, p. 263; CC). No item 8, o narrador provoca e ensina sua amante, tal como o chacareiro: "sem suspeitar que minha razão naquele momento trabalhava a todo vapor, suspeitando menos ainda que a razão jamais é fria e sem paixão, só pensando o contrário quem não alcança na reflexão o miolo propulsor” (NASSAR, 2016, p. $231 ; \mathrm{CC})$.

Nono. Além de destacar a parcela sensível da razão, o narrador-depoente mostra também o aspecto corporal da vivência, acrescentando às ideias o fundo material de onde elas vêm, questionando a cisão corpo/mente e apontando a contradição entre o pensamento da amante e sua obsessão sexual por aquilo que condena. Os "frêmitos roxos" trazem a agressividade do ato sexual e a volúpia da submissão, exatamente como a jornalista de Um copo de cólera, apresentando o paradoxo entre as "questões feministas" e o tesão em ser surrada. Diante desta incompatibilidade o narrador-depoente sugere à amante que, "nas prateleiras onde você arrumou com criterioso zelo todos os teus conceitos, encontre um lugar para esta tua paixão" (NASSAR, 2016, p. 341; VS), da mesma forma que adverte o chacareiro na novela: "você nunca tinha imaginado antes que tivesse no teu corpo um lugar tão certo pr'esse meu dedo enquanto eu te varava e você gemia" (NASSAR, 2016, p. 268; CC). 
Décimo primeiro. Recusar as verdades dos tempos modernos, recusar as certezas da imprensa especializada e recusar quem admite e prega verdades: "não tente mais me contaminar com a tua febre, me inserir no teu contexto, me pregar tuas certezas, tuas convicções" (NASSAR, 2016, p. 341-342; VS). Da mesma forma, o chacareiro recomenda: "vá pôr a boca lá na tua imprensa, vá lá pregar tuas lições, denunciar a repressão, ensinar o que é justo e o que é injusto, vá lá derramar a tua gota na enxurrada de palavras” (NASSAR, 2016, p. 244; CC).

Décimo terceiro: "não faça mais devaneio, nunca mais nada do meu corpo, nada! nada! você também vai se estrepar!" (NASSAR, 2016, p. 272; CC). Seja o chacareiro, seja o narradordepoente, ambos recusam a presença, a sedução e o domínio das amantes sobre seus corpos, como também, em "VS", o homem recusa a toalete da amante (item 14), e recusa o tratamento que ela dava a sua mãe (item 15). Desejam, portanto, que elas não mais os procurem: "não me telefone, não estacione mais o carro na porta do meu prédio, não mande terceiros me revelarem que você ainda existe" (NASSAR, 2016, p. 342; VS). Sabemos que é um blefe levando em conta o desfecho de Um copo de cólera, de modo que a recusa é tão obstinada quanto performática: “mobilizei todos os meus foles e berrei um 'puta-que-pariu-todo-mundo!', rasgando o peito, rebentando co'a jugular, me regalando grandemente co'a volúpia do meu escândalo, notando uma janela recatada da colina em frente se abrir e fechar numa só ventania" (NASSAR, 2016, p. 273; CC). A cólera do chacareiro impele novamente o fervilhar na observação da edificação vizinha, onda há um Seminário (p. 215), já que alguém, possivelmente, espia a algazarra. A recusa é obstinada porque vai fundo na contundência dos argumentos e na voracidade com que eles são apresentados e é performática pois a teatralidade é dada de largada, a passo que o presumível destino traz, em $C C$, a jornalista de volta.

Em outra direção, toda recusa para a qual Raduan Nassar mobiliza seu arsenal acaba endereçada contra aqueles próprios que recusam, se vendo, afinal, no espelho: "estava na cara que não era a dona Mariana, nem era ela, não era ninguém em particular pra ser mais claro ainda" (NASSAR, 2016, p. 231; CC). Essa interpretação favorece a hipótese de que a literatura nassariana é, afinal, uma questão pessoal, de modo que em torno de todas as questões sociais, políticas e familiares está cada sujeito e seus dramas particulares, mediante as circunvoluções de suas consciências, de seus inconscientes, de sua inteligência e sensibilidade: "só eu é que sei o que é porque só eu é que sei o que sinto" (p. 227-228). Embora vários lances se mostrem às vistas do chacareiro, ele indica que "nem via nada" (p. 227). Apenas vê na jornalista reflexos de si, aponta os dedos, a boca e a língua para a mulher, a julga e a condena como quem condena a si próprio, envolve em uma angústia culpada que mistura dramas sociais, familiares e pessoais. 
No espelho o homem se vê no mundo, como o faz André: “estranho é o mundo, pai, que só se une se desunindo; erguida sobre acidentes, não há ordem que se sustente; não há nada mais espúrio do que o mérito, e não fui eu que semeei esta semente" (NASSAR, 2016, p. 166167; LA). E quem a culpa enxerga quando o homem se olha no espelho: "ninguém em particular; eu só estava pensando nos desenganados sem remédio, nos que gritam de ardência, sede e solidão, nos que não são supérfluos nos seus gemidos; era só neles que eu pensava" (NASSAR, 2016, p. 167; LA).

O espelho, em mais uma singela incursão pela psicanálise, dá nome à fase de reconhecimento de si próprio no drama freudiano, sendo que ao se refletir o homem pode ver sua face demens, seu avesso, como diz o chacareiro, suas partes terríveis, sua sexualidade, seu tesão, sua falta de critérios e escrúpulos no emprego da violência. Recuperando o lance final de "Menina a caminho", é o espelho que mostra a vagina da garota, consagrando a mancha, imergindo-a na malícia e no pecado original do poder, da violência e moralização, abrindo caminho, também, para a metáfora do ventre, cuja pletora de significados povoa com petulância o cenário das relações humanas, tornando a sensibilidade e a consciência uma degenerescência ("VS", item 12).

Sob os auspícios da queda, nenhuma decisão é justa, nenhum passo é dado sem escolha e não há escolha que não exclua. Por isso, para tentar a justiça tentamos quebrar o espelho, tentamos recusar a todo custo a realidade tenebrosa que nos é apresentada aos olhos, criando com isso uma miríade de condicionamentos mediante os quais nos movemos à guisa de uma duplicação do real (ROSSET, 2008). Os valores são, afinal, uma ilusão sem a qual não podemos viver. Dizer o que se pensa será, finalmente, uma forma marota de cair na vida: “escrever era uma saída, resistência, atividade asseada [...] vendo depois a manipulação da produção literária, o comércio de prestígio, as paixões em jogo e etc., me dei conta de que não passamos todos duns pobres-diabos, e que fazer literatura é só um jeito maroto de cair na vida" (NASSAR, 1983, p. 105).

\subsubsection{Queda (III): escuridão progressiva}

O imaginário da queda, no conjunto de textos que discutimos neste capítulo, aponta o trauma, seja pela tensão daquilo que não é dito, seja pela cólera daquilo que é dito aos berros. O trauma traz a angústia e o ressentimento, fazendo da história social e da história pessoal de cada um uma eterna batalha contra demônios com os quais sempre convivemos. Nesse caso, o senso de justiça e o amor, fazendo suas escolhas, sempre dividem os homens, sempre excluem. Por isso, o desprezo cruel do marido em "Hoje de madrugada" pode ter sido uma experiência 
traumática, uma "progressiva escuridão que se instalava para sempre em sua memória" (NASSAR, 2016, p. 333; HM), semelhante ao efeito que a surra seguida de desprezo causa na jornalista em Um copo de cólera: "eu ainda fui gritando, sabendo que lhe abria pra sempre na memória uma cova funda" (NASSAR, 2016, p. 273; CC). Por outro lado, em "O ventre seco", a queda aparece como desistência do mundo, como desinvestimento no caminho, como recuo e recusa, de modo que se possa, ao contrário de cultivar o momento traumático, afinal, esquecêlo, do mesmo modo que o faz o protagonista de "Aí pelas três da tarde".

$\mathrm{O}$ imaginário da queda se desenvolve gradativamente em $C C$, de maneira que quanto mais o casal tenta se desvencilhar um do outro, quanto mais eles dispersam e soltam seus demônios, quanto mais se elevam em forma e conteúdo, mais se instala a escuridão do trauma. Quanto mais sobem, mais caem, até que o estertor, a agressão, a crueldade, a submissão da mulher que gosta de apanhar, a barbárie do chacareiro, quando todos os cacos estão no chão, quando, afinal, a violência e a guerra tomam conta da situação, é o machão que se suspende ao solo, cedendo à infantilidade e às memórias familiares:

nos parecendo sempre lúcida a mão maciça que nos conduzia, era sem dúvida gratificante a solidez dessa corrente, as mãos dadas, a mesa austera, a roupa asseada, a palavra medida, as unhas aparadas, tudo tão delimitado, tudo acontecendo num círculo de luz contraposto com rigor sem áreas de penumbra - à zona escura dos pecados, sim-sim, não-não, vindo da parte do demônio toda mancha de imprecisão, era pois na infância (na minha), eu não tinha dúvida, que se localizava o mundo das ideias, acabadas, perfeitas, incontestáveis, e que eu agora — na minha confusão - mal vislumbrava através da lembrança (ainda que viesse inscrito no reverso de todas elas que “a culpa melhora o homem, a culpa é um dos motores do mundo"), ao mesmo tempo em que acreditava, piamente, que as palavras impregnadas de valores - cada uma trazia, sim, no seu bojo, um pecado original (assim como atrás de cada gesto sempre se escondia uma paixão), me ocorrendo que nem a banheira do Pacífico teria água bastante pra lavar (e serenar) o vocabulário (NASSAR, 2016, p. 275-276; CC, grifo nosso).

Em um claro prenúncio de Lavoura arcaica, este trecho localiza precisamente nas palavras, no discurso, em todos os nomes e expressões que uma cultura é capaz de criar o pecado original. É, afinal, na linguagem que o poder reside e daí se faz sua confusão. Renomear e ressignificar, buscar justiça histórica, implica chamar golpe uma suposta revolução, sacudindo com isso os corações e mentes do lado oposto. Entretanto, se o critério racional projeta, com sua luz, a dualidade entre o bem e o mal, a confusão e a gradação dos pontos de vista, que imprime um olhar capaz de captar as tessituras do poder, será vista como pecado, como traição ideológica, seja qual for a ideologia. Conceber a complexidade das coisas, então, vai como um vício, um crescente motivo que corrompe progressivamente o olhar daqueles que dispensam as dicotomias e o pensamento uno. Essa corrupção, escuridão progressiva, contamina como 
mancha, um demônio que chega até nós sendo "facilmente apreensível pelo lápis de alguns raros retratistas" (NASSAR, 2016, p. 341; VS).

Incapaz de superar as tradições familiares e os valores milenares, o chacareiro cede à culpa e à desistência: "fiquei um tempo ali parado, olhando o chão como um enforcado" (NASSAR, 2016, p. 274; CC), a mesma culpa e o mesmo gesto decadente que faz Zeca Cigano após surrar a esposa ao final de "Menina a caminho". Nesses termos, a moral estaria sempre ligada a um devir-mal, a uma cisão primeva que divide e tiraniza. A consciência culpada é a garantia de uma demonização do próprio divino, como também nota Georges Bataille (2015). Ricoeur, por sua vez, encerra a fenomenologia do mal rigorosamente imiscuída na condição do homem:

\footnotetext{
A sobriedade da consciência penitente exclui a possibilidade da especulação sobre Satã ser desligada um dia da antropologia do mal. O homem não conhece o mal senão como aquilo que inaugura; é por isso que é sempre necessário um primeiro passo na "satanologia”, nos confins da experiência do ser-tentado" (RICOEUR, 2015, p. 278279).
}

Assim sendo, a explosão colérica que deriva na agressão se mostra como pecado, reinaugurando o ciclo da simbólica do mal, dando um passo inicial na escuridão progressiva que contamina (transpondo a soleira), fazendo das relações mútuas o repositório primevo das divergências. No instante seguinte, o chacareiro cai pensando na jornalista, em sua solidão e nos valores que os aprisionam como casal. O jorro das palavras cessa, não há nada para escorálo, não há combate, apenas o silêncio:

\footnotetext{
no meio daquela quebradeira, de mãos vazias, sem ter onde me apoiar, não tendo a meu alcance nem mesmo a muleta duma frase feita, eu só sei que de repente me larguei feito um fardo, acabei literalmente prostrado ali no pátio, a cara enfiada nas mãos, os olhos formigando, me sacudindo inteiro numa tremenda explosão de soluços (eram gemidos roucos que eu puxava lá do fundo) (NASSAR, 2016, p. 276-277; CC).
}

Finalmente, as mãos que erguem o "machistão" do chão são dos caseiros, gente comum que sequer entendeu os termos da discussão daquele casal. Voltando à condição infantil, o chacareiro volta a colocar sua atenção nos coelhos, na terra. Na sequência, a espera marcada pela circularidade do destino, "não era a primeira vez que ele fingia esse sono de menino" (p. 280). A tranquilidade e o silêncio daquela cena prenunciado os estertores das novas volúpias que seguirão tomando os dramas conjugais e sociais: a simulação, o transe, a demagogia, o delírio, que fazem a literatura nassariana alcançar, no interior, a humanidade de cada homem, entrevista, de permeio, através dos estilhaços de um espelho torto. 
Nos textos analisados neste capítulo são recuperados os traumas como matéria pulsante das relações humanas, migrando a comunicação entre as pessoas para o terreno das memórias infantis e para a materialidade telúrica do corpo, que dará cadência e lirismo para a análise de Lavoura arcaica, no próximo capítulo. Nesse caso, o microcosmo do casal e a teatralidade da vida conjugal ganham a proporção dos vícios oriundos da edificação de valores na família. É o próprio convívio entre aventura e prisão, na condição humana, que substancia a deseducação nassariana, desfazendo ideias feitas, recompondo traços da constituição dos povos, destituindo ídolos, desmascarando a inocência e a felicidade conjugal e lançando em um halo oco e sem fim os dramas da existência. 


\section{O ELOGIO DA DIMENSÃO SENSÍVEL E ESTÉTICA DA VIDA}

Figura 9 - Perdidas entre os afazeres na cozinha

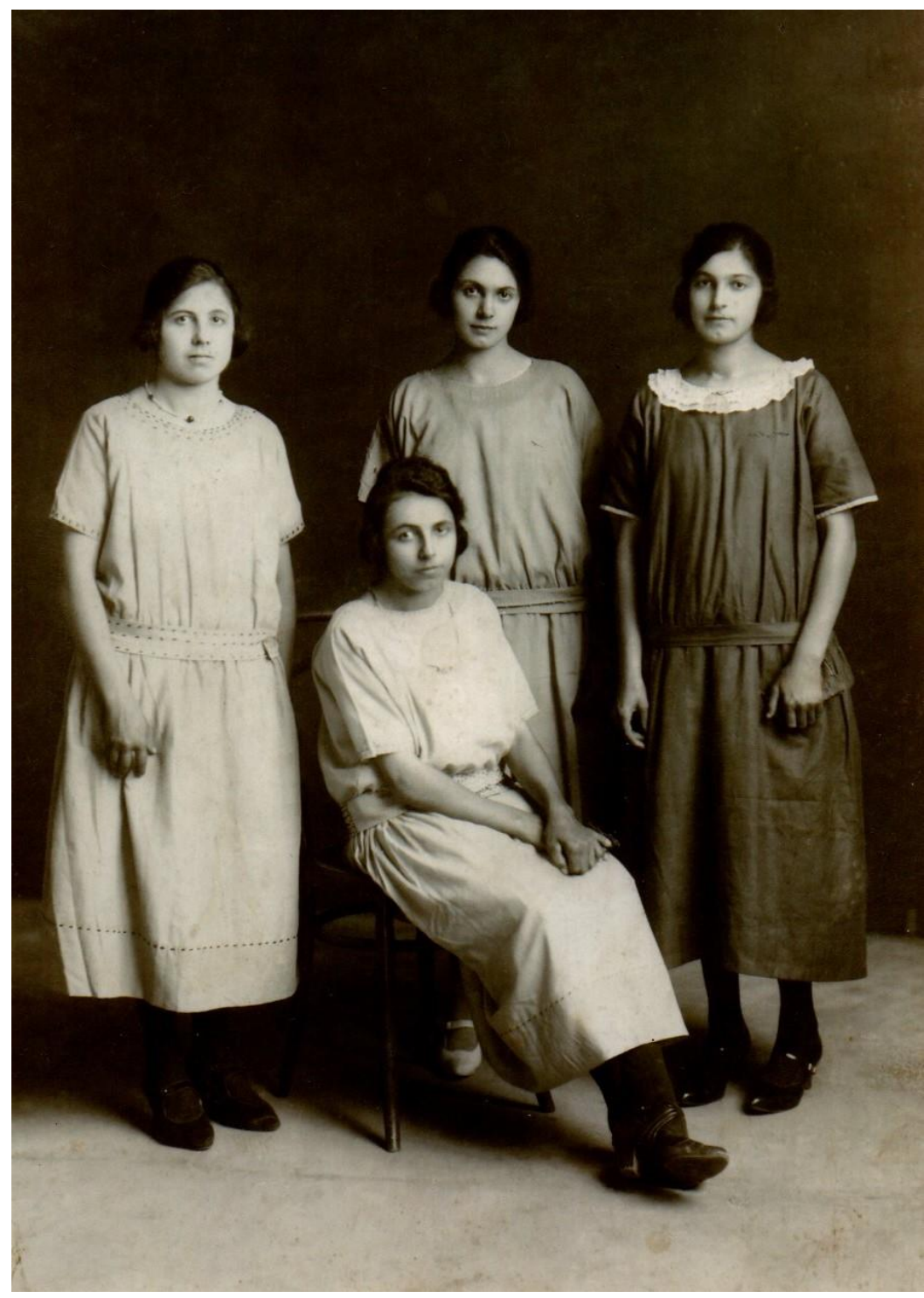

Fonte: arquivo familiar (década de 1920)

Ao meio e ao fundo, minha bisavó, Zepha Rossi, e à volta suas irmãs. Anteriormente chamada por "Bepha" e mais à frente simplesmente "Nona". À esquerda, Luiza, à direita, Olga, ao meio na cadeira, Ilda. "Como fundo um cenário irreal". A elegante simplicidade das vestes soma-se ao ar prosaico das mulheres da família. Em torno do fundilho escuro deste cenário, a protuberância arcaica de um feminino confuso e indeterminado, balizando com vigor o mistério no arquétipo da mãe. Era um tempo de esperas, em que o gesto mais ínfimo coletava a candura e a virulência dos olhares. 
Figura 10 - Era uma ciência de menino

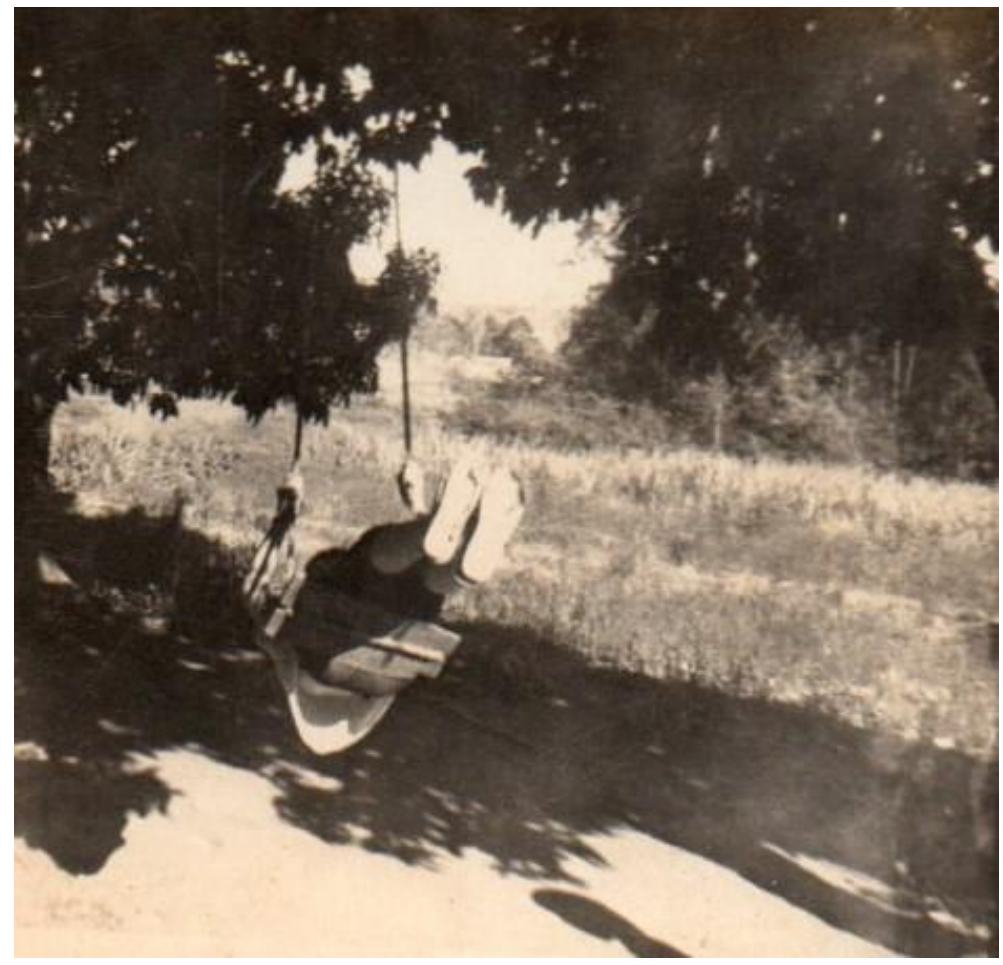

Fonte: arquivo pessoal (1969)

Valter Cremasco, meu tio, à sombra da mangueira. Somada ao pêndulo lúdico deste balanço, a árvore ao fundo vasculha imagens de quando, com tenra idade, conheci meus "bisas", debaixo de uma jabuticabeira. $\mathrm{O}$ fruto doce e negro alcança os arcaicos lances do tempo.

Figura 11 - O galho da esquerda

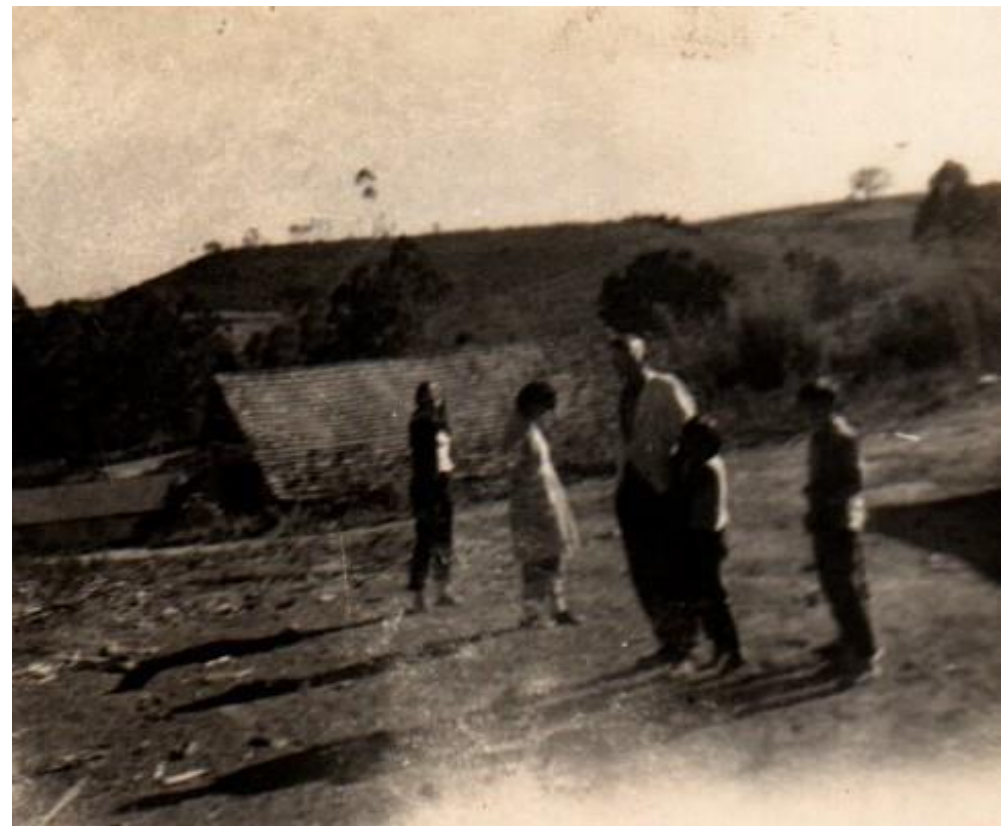

Fonte: arquivo familiar (1969) 
Da direita para a esquerda, Valter, Neuraci, José Zandona, Lídia e Célia. Um jogo de luz e sombra não nos permite discernir o porvir incerto de cada galho desta trama.

Figura 12 - Não tinha olhos esse nosso avô

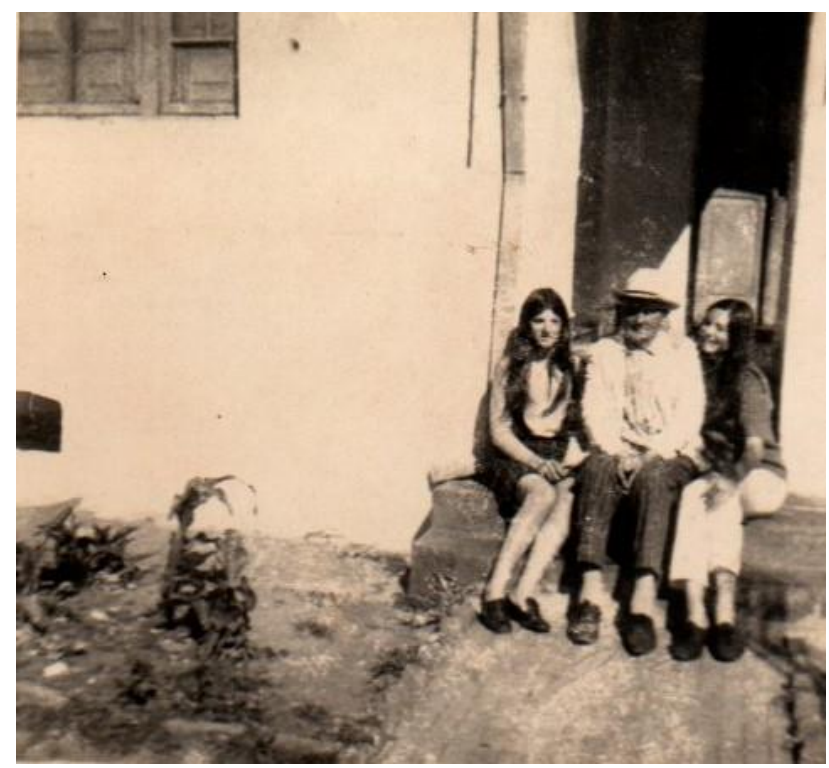

Fonte: arquivo familiar (1969)

Antônia Bortoleto e Célia Cremasco amparam o "Nono" à entrada da casa da família na Avenida Independência, em Piracicaba.

Figura 13 - Uma fotografia castanha

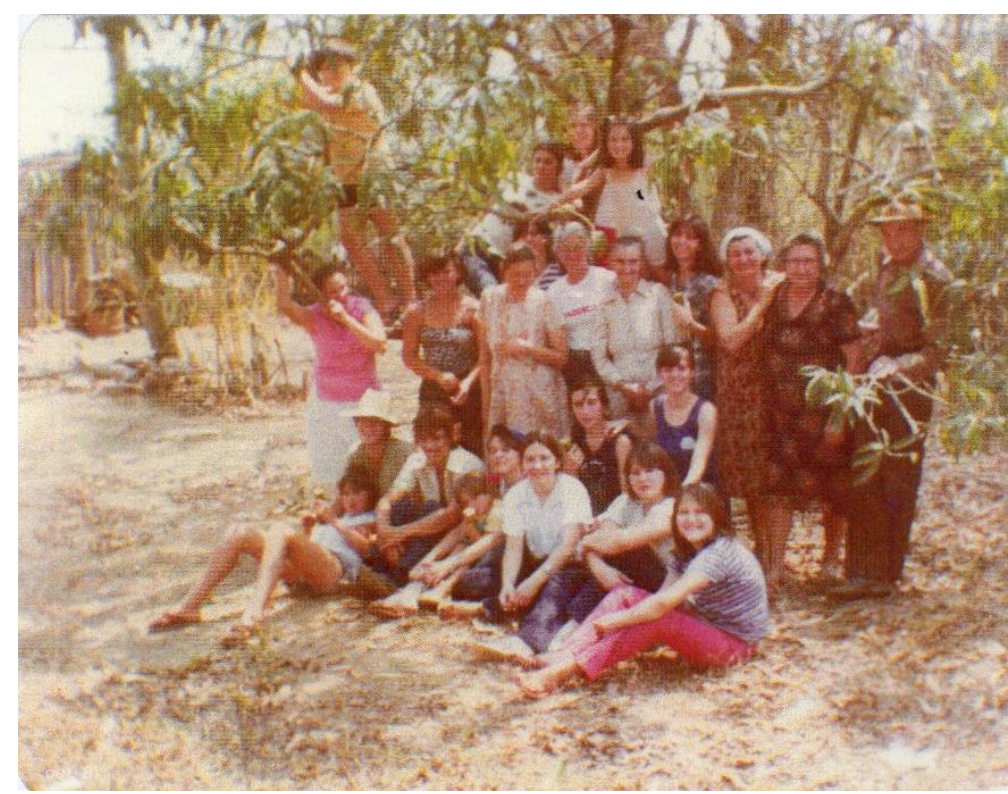

Fonte: arquivo pessoal (1981) 
Rodrigo, Palmira, Loriz, Daniela, Eunice, Sônia, Lídia, Lúcia, Zepha, Célia, Maria de Lourdes (minha avó), Ana, Avelino, Bimbo, Gerson, Robson, Claudeni, Magali, Margareth, Rosângela, Arlete, Renata. Pessoas comuns; anônimos.

Lavoura arcaica (LA) reúne referências remotas da ancestralidade judaico-cristã, do paganismo, do hermetismo, da alquimia, da cultura helênica e da cultura árabe, amalgamadas em uma narrativa que admite traços épicos, epistolares e poéticos, confundindo territórios e memórias através de seus enxertos - ora omissos, ora manifestos - perfazendo parábolas e paródias que se perdem em um labirinto de repetições, inversões e dispersões. No romance as relações entre o microcosmo do corpo e o macrocosmo da natureza se abrem em nuances que incluem o núcleo familiar, as edificações, as áreas externas da fazenda e o espaço opaco e ampliado das memórias, conduzindo simetrias e assimetrias entre os elementos naturais e os sentidos corporais. A consciência, a reflexão e o pensamento assumem formas flutuantes, cujas mediações indicam as tentativas de controle e domesticação do devir, de modo que as previsões e as certezas se desfazem mediante os embates simbólicos que a obra conduz.

Nessa direção, o romance de Nassar mobiliza aspectos do imaginário da queda, em torno dos quais constelam traduções tão ecléticas quanto obliquas, demandando símbolos cuja riqueza de sentido fazem da obra uma experiência intensa de desconstrução pessoal: "romance com reflexão crítica, que transmite ao leitor recursos para confrontar significativamente a sua história e a história de outros homens, Lavoura arcaica não é livro fácil e, apesar da explosiva carga lírica, exige o atento trabalho da inteligência do leitor" (ABBATE, 1976 apud ABATI, 1999, p. 21).

As presenças notáveis do erotismo e da transgressão convocam registros do imaginário da queda. Os dramas e tabus envolvendo a sexualidade constituem matéria comum por onde transitam histórias de muitas gerações, conferindo ao Ocidente a marca indelével da negação do corpo, conquanto a força da história pessoal do leitor situa sua condição humana no instante primordial da cultura. Segundo Paul Ricoeur, "o mito adâmico narra como um acontecimento a passagem da inocência ao pecado enquanto estatuto de um homem destinado para o bem e inclinado para o mal" (RICOEUR, 2015, p. 253). Assim, é a própria dinâmica da vida, em seus abruptos movimentos, o que garante a passagem da condição idílica para a conflitualidade moral, reiterando o mal como força ambígua: destrói e rompe enquanto contamina e condena. 


\subsection{O EROTISMO E OS ECOS ANCESTRAIS}

A citação do poeta Jorge de Lima inaugura o romance, sendo repetida por André no capítulo 20, quando fala da paixão por Ana: "que culpa temos nós dessa planta da infância, de sua sedução, de seu viço e constância?” (NASSAR, 2016, p. 133; LA) ${ }^{45}$. No contexto infantil a linguagem e a corporeidade assumem um só filamento, determinando e contaminando a constituição do sujeito de modo incontornável. O que se manifesta no microcosmo da pessoa é espelhado nos recônditos da cultura, alcançando uma zona de indeterminação na qual valores pessoais, familiares e comunitários se (con)fundem e entram em conflito à medida que o fluxo da vida se faz.

O romance nassariano, apelando aos sentidos e às sensações, recupera a condição originária da natureza humana, exilando o sujeito da compreensão plena de si e do mundo. A imprevisibilidade do comportamento atende às mesmas dissonâncias perturbadoras que regem a implacabilidade do destino, desvelando o sinuoso caminho das histórias, uma corrente que liga o passado ao presente, atrelando entre si gerações e gerações, e aprisionando, ao mesmo tempo, aqueles que se reúnem em nichos e grupos sociais, como é o caso da família e da vizinhança na literatura nassariana.

O imaginário da queda reenvia os dramas familiares à constituição do homem, tornando o mito adâmico um propósito que convém à distinção dos gêneros sexuais, de modo que a origem comum de homem e mulher, a terra, é também a origem comum de André e Ana, a mãe. Nesse caso, o androginato adâmico inaugura a condição do antropos: "Eva não é [...] a mulher enquanto 'segundo sexo'; toda mulher e todo o homem são Adão; todo o homem e toda a mulher são Eva; toda mulher peca 'em’ Adão, todo homem é seduzido 'em' Eva” (RICOEUR, 2015, p. 274). André localiza na infância e na relação com a mãe a danação primeva, a violência fundamental do erotismo, o inaugurar da consciência do bem e do mal.

A diferença entre o homem e os demais animais é que nossa violência é, também, simbólica, uma vez que desejamos combater a ameaça de morte. Segundo Bataille (2014;2015), a morte é a violência maior ao ser humano, pois coloca em ameaça a duração do ser descontínuo que somos. Desejamos permanecer no jogo de conquista do aquém, para o qual o sagrado é o melhor exemplo. Por que o sagrado é a promessa da continuidade (BATAILLE, 2014) ou da intimidade (idem, 2015) perdida por ocasião do nascimento. Homologamente, em Durand (2012), a intimidade se expressa simbolicamente nas águas calmas, no apelo telúrico ao ventre

\footnotetext{
${ }^{45}$ Citação literal extraída do Canto 1 (Invenção da Ilha) - Invenção de Orfeu (LIMA, 2017).
} 
materno, pátria mãe: em $L A$, os afetos desmedidos, os mensageiros mais velozes da união e da sensibilidade noturna.

Para Bataille (2014) só a canalização erótica da desordem pode aceder à experiência momentânea de continuidade, apoteose dionisíaca. A plenitude do erotismo se dá no sagrado, uma vez projetada a continuidade do ser terreno no espiritual. A vontade procura o que está fora, o indizível, um plano no qual a continuidade possa ser experimentada, remontando à quietude do útero. Assim, a condição extemporânea é o primado da religião:

\begin{abstract}
a busca de uma continuidade do ser perseguida sistematicamente para além do mundo imediato aponta uma abordagem essencialmente religiosa; sob sua forma familiar no Ocidente, o erotismo sagrado confunde-se com a busca, exatamente com o amor por Deus, mas o Oriente dá continuidade a uma busca semelhante, sem necessariamente colocar em jogo a representação de um Deus (BATAILLE, 2014, p. 39-40, grifo nosso).
\end{abstract}

Percebemos que a busca, o caminho, é uma condição humana, solidária das dimensões mais primitivas do erotismo, conquanto a continuidade do ser demanda seu desdobramento em outro ser, de modo que a experiência da paixão aparece como possibilidade de alcançar a plenitude, recuperando a um só tempo a ancestralidade dos ciclos e um telos em que a pletora de sentimentos e sensações se estabilize enquanto intimidade. Nessa direção, o erotismo implica uma violência, uma violação, pois sugere um espaço numênico em que a vontade e o poder assumem o controle à medida que a ultrapassagem do interdito é experimentada em um círculo supramoral, posto que impõe ao gozo um cenário transcendental, o inefável.

O narrador-personagem, André, compõe imagens de intimidade que se vão deslocando em símbolos da descida. Conforme o imaginário durandiano, a transgressão conduz à inversão. Na primeira parte do livro isso fica patente. Já na segunda parte há um predomínio dos símbolos cíclicos apontando para a implacabilidade do destino. Nesse sentido, a primeira parte do romance está para uma estrutura de sensibilidade mística enquanto a segunda parte está para uma estrutura de sensibilidade dramática (DURAND, 2012). No primeiro momento o conforto inocente da união familiar cindido pelo erotismo incestuoso demarcando a dialogia bem e mal. Na segunda parte, André, fracassado, se subsome à implacabilidade do destino se mantendo indiferente à face terrífica do tempo.

A vida e as criações humanas se apresentam como posturas simbólicas diante do devir, ao que a provisoriedade toma corpo e corrompe a pretensa estabilidade de quaisquer valores. As simetrias entre o passado mítico e primitivo e um telos povoado de uma espécie de violência sagrada garantem o espaço das referências bíblicas e dos ecos orientais em $L A$. Ao trazer o 
corpo e a natureza como temas, Nassar confunde o que é pagão e o que é litúrgico, amalgamando terra, água, fogo, ar e éter com olfato, paladar, visão, tato e audição, imiscuindo o corpo humano nas formas naturais e deslocando, com isso, os parâmetros milenares com os quais se mede e regula a vida familiar e comunitária. A profusão de referências com as quais o romance conversa recupera a imbricação entre as culturas judaico-cristãs que se desenvolveram em território sírio-palestino, influenciadas também por traços helênicos. O gnosticismo cristão congrega uma série de costumes e crenças amalgamadas em $L A$ :

\begin{abstract}
Nos textos gnósticos cristãos, encontram-se elementos presentes da filosofia religiosa helenista, do dualismo persa e a iniciação nos mistérios. Procurando elementos para o conhecimento de si mesmo, o gnosticismo buscava responder, a partir de relatos míticos, à pergunta sobre as origens e os destinos do homem, e salvar o espírito corrompido com uma queda no mundo sensível, onde se acha prisioneiro da matéria, representada como o mal. Acentua, também, a tendência dualista da doutrina a busca de libertação através do ascetismo e mortificação, suplantação de desejo e egoísmo e na observância dos preceitos morais (ABATI, 1999, p. 170).
\end{abstract}

O mundo sensível, percebido e confrontado com o corpo, encarna o mal à medida que o mundo das ideias, platônico, persiste na filosofia cristã como manifestação do próprio Deus. A busca socrática pela verdade incide na onipotência metafísica da divindade cristã, como se pode ver em Agostinho de Hipona. O equilíbrio dos gregos se vai transformando, no contexto medieval, na supressão do corpo, reiterando o mundo sensível como engano, como em Platão, mas avançando e impingindo neste engano a demonização e o mal. Assim, Deus é a verdade, o que confere ao pensamento uno a radicalização contra aquilo que é impreciso e relativo, entendido como desviante e errôneo.

O estatuto metafísico da divindade, na modernidade, assume-se como elemento de sustentação moral, estribado no imperativo moral kantiano. Se a moral se insinua como terreno asséptico, são os valores em si a manifestação dos preceitos da lei divina, entendida como fundamento do espírito, o que possibilita o paralelo do divino com a razão. Além disso, para conectar seres imperfeitos e descontínuos ao Deus soberano e uno, é preciso aceder à graça, recorrendo ao Espírito Santo, o que significa suprimir a vontade e o egoísmo, como aponta Schopenhauer. Diante disso, Raduan recorre à parábola do filho pródigo para atribuir à vontade sua ambiguidade entre poupança e dispêndio, radicando na coesão de seu texto a promiscuidade dos textos sagrados, nos quais a violência, a guerra, a peste a fome convivem com o amor e a misericórdia. 
os seus haveres, o filho mais jovem partiu para uma região longínqua e ali dissipou sua herança numa vida devassa. E gastou tudo. Sobreveio àquela região uma grande fome e ele começou a passar privações. Foi, então, empregar-se com um dos homens daquela região, que o mandou para seus campos cuidar dos porcos. Ele queria matar a fome com as bolotas que os porcos comiam, mas ninguém lhes dava [...] Partiu, então, e foi ao encontro de seu pai [...] 'Pai, pequei contra o Céu e contra ti; já não sou digno de ser chamado teu filho'. Mas o pai disse aos seus servos: 'Ide depressa, trazei a melhor túnica e revesti-o com ela, pondo-lhe um anel no dedo e sandálias nos pés. Trazei o novilho cevado e matai-o; comamos e festejemos, pois este meu filho estava morto e tornou a viver; estava perdido e foi reencontrado!' (Lc 15:11-24).

Porém, o irmão mais velho que estava no campo ao chegar e ver a festa indigna-se: "há tantos anos que te sirvo, e jamais transgredi um só dos teus mandamentos, e nunca me deste um cabrito para festejar com meus amigos" (Lc 15:29). Dito isto, o pai o responde: "filho, tu estás sempre comigo, e tudo o que é meu é seu. Mas era preciso que festejássemos e nos alegrássemos, pois esse teu irmão estava morto e tornou a viver; ele estava perdido e foi reencontrado!" (Lc 15:31-32). Notadamente, o trecho bíblico omite o que ocorreria na sequência, mantendo a lição de misericórdia e perdão.

A narrativa de Raduan, por sua vez, subverte esses valores salientando a impossibilidade de reconciliação familiar, introduzindo na omissão bíblica a perturbação do irmão mais velho, Pedro, que confessa ao pai a cena incestuosa de André e Ana, recobrando os valores familiares, que se invertem no desfecho violento. Não obstante, é justamente sobre a manifestação oral e escrita dos valores que se lança a deseducação nassariana, decompondo a sustentação moral do discurso em frestas, fissuras pelas quais se entreveem fístulas purulentas, chagas de um passado mítico e histórico comum, mediante o qual se multiplicam interpretações.

$\mathrm{Na}$ primeira parte de $L A$ os símbolos de intimidade se multiplicam no fluxo de consciência de André, que além de narrar seus dramas pessoais, traz à tona as ambiguidades silenciadas no cotidiano familiar, dando tônus às partes omissas dos sermões paternos, destacando interpretações divergentes, "pisoteando as páginas de muitos livros" (NASSAR, 2016, p. 92; LA). Além disso, não só as contradições paternas são expostas, mas a ternura e o ar benfazejo dos cuidados maternos também são postos a prova pelos critérios de André, se valendo da mistura entre métricas do discurso e da oratória e métodos alquímicos obscuros, compondo a convivência da razão com o que há de pagão nos ritos familiares.

A composição etérea da fazenda, das casas, do bosque, do quarto e do corpo traduzem a circulação das palavras do pai, ecoando nas fissuras e nas dobras de cada membro do corpo, como o faz em cada membro da família. Nessa direção, os ambientes, os cômodos e a natureza são descritos partilhando emoções humanas, como é o caso do quarto de pensão, onde o romance tem início: “o quarto é inviolável; o quarto é individual, é um mundo, quarto catedral, 
onde, nos intervalos da angústia, se colhe, de um áspero caule, na palma da mão, a rosa branca do desespero, pois entre os objetos que o quarto consagra estão primeiro os objetos do corpo" (NASSAR, 2016, p. 11; LA). A inviolabilidade do quarto o coloca tanto na condição de objeto único e individual quanto como portador de uma forma específica, cujos contornos contemplam seu morador e as sensações e sentimentos por ele experimentados. Nesse sentido, a masturbação evoca imagens corporais: "peito", "cabeça”, "cabelos", "faces”, “olhos”, “cílios", “orelha”, "mão", "sexo", "braços", “ombros" (p. 12-13). Por conseguinte, a angústia descontínua de André encontra trégua na volúpia do onanismo, repercutindo no corpo o índice de um gozo possível.

A embriaguez de André é interrompida com as batidas na porta. É seu irmão Pedro, encarregado de devolvê-lo à família: "era um espaço de terra seca que nos separava, tinha susto e espanto nesse pó" (p. 13). A imagem telúrica demanda a origem comum dos irmãos, colocando em cena os carinhos desmedidos da mãe. A terra, símbolo de descida, é isomórfica do ventre, do útero materno: "primitivamente, a terra, tal como a água, é a primordial matéria do mistério, a que é penetrada, que é escavada e que se diferencia simplesmente por uma resistência maior à penetração" (DURAND, 2002, p. 230). A terra remete às origens, ao ventre, à mãe, mas a austeridade da lei paterna retira o aspecto fluido do ventre em favor da ordem: “abotoe a camisa, André” (NASSAR, 2016, p. 14; LA).

O amor familiar desponta tanto na forma de cuidado, ternura e perdão, como em castigo, castração e recusa, como o faz o amor divino, compondo simetrias entre amor conjugal (eros), amor familiar (philia e/ou storge) e amor sagrado (ágape): "nós te amamos muito, nós te amamos muito" (p. 13). É, justamente, na ambiguidade do amor como valor que o romance recusa a razão asséptica, que pretensamente edificaria a vida geração após geração, de modo linear e regrado. Neste primeiro capítulo é propriamente o amor familiar que rompe a volúpia sinestésica de André, de modo que a ternura de todos os membros da casa sopesam na missão de Pedro, precipitando senão um resgate, a deixa para as confissões vindouras.

No capítulo subsequente se inicia o relato adolescente: "era num sítio lá do bosque que eu escapava aos olhos apreensivos da família; amainava a febre dos meus pés na terra úmida, cobria meu corpo de folhas e, deitado à sombra, eu dormia na postura quieta de uma planta enferma vergada ao peso de um botão vermelho" (p. 15). Os pés, que favorecem a conexão com a terra, sugerem a corporeidade de André imiscuída na natureza do húmus, traduzindo a intimidade da vontade no repouso. Uma das primeiras imagens de intimidade é o bosque: 
a floresta é centro de intimidade como o pode ser a casa, a gruta ou a catedral. A paisagem silvestre fechada é constitutiva do lugar sagrado. Todo lugar sagrado começa pelo 'bosque sagrado'. O lugar sagrado é uma cosmicização maior que o microcosmo da morada, do arquétipo da intimidade feminóide (DURAND, 2002, p. 246).

A sagração do bosque orna com a proteção dos pastos, da capela, da casa e dos cômodos, correspondentes a delimitação do espaço beatificado pela palavra do pai e pelo cuidado da mãe. A intimidade sagrada prenuncia a voracidade transgressiva do erotismo adolescente: "(meu sono, quando maduro, seria colhido com a volúpia religiosa com que se colhe um pomo)" (NASSAR, 2016, p. 16; LA). André, como planta enferma, compraz a geometria disforme da flora que se desenvolve a esmo, com sua ecologia interna, de onde brotam frutos de diferentes estirpes. Oriundas da terra, as palavras, assim como os corpos, desenvolvem caminhos tortuosos, perfazendo tanto a quietude de um bosque quanto a voracidade dos animais que nele habitam. A linguagem desperta no corpo adolescente de André a expressão de uma vontade imperiosa, que se aconchega como erva daninha na ecologia familiar, alimentando a volúpia das espécies que gravitam em torno do caule perfeito daquela árvore genealógica. O ímpeto adolescente de André é gestado na própria sagração do ambiente familiar.

Na sequência, surge o vinho na beberagem dos irmãos acertando as contas da família. O dionisíaco, em $L A$, se apresenta nas imagens de transgressão, violência e festa. André relata suas primeiras crises durante aquela conversa: "já tinha voltado à mesa para encher dois copos quando escorreguei e quase perguntei por Ana" (p. 18). Em seguida, se lembra da ternura maternal: "não fique assim na cama, coração, não deixe sua mãe sofrer, fale comigo" (p. 20). As lembranças de Ana e da mãe perturbam o protagonista, que permanece trancado em seu tenso silêncio. Quem inicia a conversa é Pedro, resgatando a palavra paterna: "era uma oração que ele dizia quando começou a falar (era o meu pai) da cal e das pedras da nossa catedral" (p. 20). Note-se que sem se valer claramente de uma religião em si o texto transpõe a fé ao plano da moral, vertendo a doutrina em código moral. Além disso, este código moral se compõe na arquitetura das edificações, como as casas e a capela da fazenda, dando aos valores familiares a projeção metafórica de um edifício, enquanto impregna materialmente cada espaço do ambiente familiar. É a memória daquela família que investe as turvas reflexões de André, confrontadas em sua sinuosidade, com a suposta retidão das memórias de Pedro. Nos diálogos iniciais entre os irmãos no quarto de pensão são odores, cores, posturas, gestos, expressões e palavras daquela estória que se fundem na miríade de sentimentos provocados pela partilha daquela genealogia comum. 
No quarto capítulo acompanhamos o amor de André por uma cabra que foi trazida à fazenda para misturar seu sangue: "adolescente tímido, dei os primeiros passos fora do meu recolhimento: saí da minha vadiagem e, sacrílego, me nomeei seu pastor lírico” (p. 23). O cuidado do protagonista para com a cabra transpõe os limites da ternura vazando para a perversão sexual: "Schuda, paciente, mais generosa, quando uma haste mais túmida, misteriosa e lúbrica, buscava no intercurso o concurso do seu corpo" (p. 23). Nesse caso, o profundo desejo de ternura, cuidado e amparo para com o animal deslindam na virulência da violação, conformando o "erotismo corporal", conceito de Georges Bataille:

não apenas encontramos, nas perturbadoras passagens dos animálculos envolvidos na reprodução, o fundo da violência que nos sufoca no erotismo dos corpos, mas o sentido íntimo dessa violência se revela para nós. Que significa o erotismo dos corpos senão uma violação do ser dos parceiros? Uma violação que confina com a morte? Que confina com o assassinato? (BATAILLE, 2014, p. 40-41, grifo nosso).

O "erotismo dos corpos" ou "erotismo corporal" indica uma violência inerente no contato carnal e sexual, uma violência que expressa o desejo de uma continuidade na morte. Extrapolando o contato carnal entre André e Sudanesa, a ligação entre os corpos desta narrativa perfaz os movimento íntimos que traduzem a ausência e a solidão nos arroubos intensos e performáticos da vontade, que não deseja senão romper o isolamento corporal do mesmo modo que rompe os limites da casa e da fazenda. Mediante o desamparo e o desassossego da tirania do tempo e da austeridade do trabalho, a violência erótica se imprime buscando a continuidade naquilo que está fora do alcance da proteção familiar. O movimento erótico se faz como um ímpeto que dilacera e desfaz as roupas, as máscaras, desconstituindo a possível ingenuidade que haveria na ligação entre um jovem do campo e sua cabra predileta. Assim, quando André viola Sudanesa implode também a si próprio, inaugurando um turvo canal de comunicação por onde transitará tudo o que é vedado à moral paterna, o que sinaliza a contaminação recíproca entre o que entra e o que sai do corpo. Nesse caso, o erotismo dos corpos demanda a corrupção e a destruição simbólica do objeto de desejo:

a ação decisiva é o desnudamento. A nudez se opõe ao estado fechado, ou seja, ao estado de existência descontínua. É um estado de comunicação, que revela a busca de uma continuidade possível do ser para além do fechamento em si mesmo. Os corpos se abrem à continuidade através desses canais secretos que nos dão o sentimento da obscenidade. A obscenidade significa a perturbação que desordena um estado dos corpos conforme à posse de si, à posse da individualidade duradoura e afirmada (BATAILLE, 2014, p. 41, grifo nosso). 
A literatura nassariana, como estudamos no segundo capítulo, realiza este desnudamento, desmascarando os personagens do cotidiano ao mostrar seu lado tosco, simulado e caído, na perspectiva de abrir um lastro comunicativo cuja potência ultrapassa os limites da razão, uma vez que a sensibilidade circula através dos "mensageiros mais velozes" (NASSAR, 2016, p. 16; LA). Assim sendo, os sentidos corporais captam as mensagens da natureza antes mesmo de absorverem os preceitos morais. Não obstante, os próprios valores familiares se (con)fundem às intimações da natureza e dos corpos de cada membro da família, de modo que discernir entre razão e emoção se torna uma operação artificial para André, que alimenta seu discurso convulso imiscuindo paixão e razão.

No capítulo 5 Pedro insinua a imaturidade de André apontando que, de acordo com os preceitos da família, seria necessário estar atento para evitar a queda "pois bastava que um de nós pisasse em falso para que toda a família caísse atrás" (p. 25). O deslize diante do caminho estreito dos valores familiares, ocasião da queda, é a transposição dos limites do interdito, remontando à ancestralidade do comportamento desejado para aquele grupo de pessoas, que se investe como corpo social. Para Pedro, assim como para Iohána, a queda configura-se no campo da ameaça, da mancha que vem de fora, mas que pode ser inflamada pelo pecado, quando se pisa em falso: "é portanto sob o signo da ameaça total, e no contexto de uma espécie de agressão de Deus ao seu povo, que o homem é revelado a si mesmo" (RICOEUR, 2015, p. 70). Nesse caso, cada parte do corpo, como cada membro da família, pode funcionar como anomalia, bastando para isso que uma influência externa manchasse seu programa, levando todos os membros do grupo a penalização vingativa da tábua de valores, entrevendo a face violenta da ordem, materializada no pai como se poderia ver na imagem do Deus colérico: "a representação verídica de Deus que lhe corresponde é a 'Cólera'; não é que Deus seja mal, mas a Cólera é o rosto que a Santidade assume para o homem pecador" (RICOEUR, 2015, p. 80).

Seria, portanto, sob a ameaça de queda que cada componente da família cuidaria de se manter no caminho estreito, já que um passo em falso traz também a punição de outrem, completando em culpa a simbólica do mal. Essa vingança diante do pecado imprime naqueles manchados a mácula da culpa, desfazendo a necessidade de uma punição física, já que a culpa materializa a penitência na angústia e na tensão que permeiam a situação daquele que erra. A autopunição desvia, portanto, a necessidade de um Deus no flagelo, traduzindo o mal em estados de consciência e espírito penosos e torturantes, o que permite a Lavoura arcaica diluir suas referências cristãs e islâmicas na memória coletiva de todos os homens. Embora a culpa assuma mecanismos diversos a depender da cultura, preservam-se sentimentos imprecisos que marcam a turva transição entre a linguagem e a materialidade do mundo, o que dispõe a angústia 
e a tensão em (est)éticas específicas, conquanto todas elas partilham os aspectos tenebrosos dos limites entre os valores aceitos e aqueles recusados.

Por outro lado, a sagacidade do protagonista permite ver as nuances e distorções que compõem o halo inadvertido que faz dos limites um espaço indeterminado e maleável, lançado à sorte daquele que interpreta os valores que escoram o itinerário pretendido, tendo em vista, inclusive, as divergências de valores entre diferentes culturas. Assim, para André, a queda estava consumada há tempos porque, como excluído, sentia a violência da moral paterna na condição de irmão decaído, já influenciando a penitência de todos os familiares com sua errância. No contexto de $L A$, os pilares morais da família são calcados no dever:

\begin{abstract}
para manter a casa erguida era preciso fortalecer o sentimento do dever, venerando os nossos laços de sangue, não nos afastando da nossa porta, respondendo ao pai quando ele perguntasse, não escondendo nossos olhos ao irmão que necessitasse deles, participando do trabalho da família, trazendo os frutos para casa, ajudando a prover a mesa comum, e que dentro da austeridade do nosso modo de vida sempre haveria lugar para muitas alegrias, a começar pelo cumprimento das tarefas que nos fossem atribuídas, pois se condenava a um fardo terrível aquele que se subtraísse às exigências sagradas do dever (NASSAR, 2016, p. 25; LA).
\end{abstract}

O trabalho é a lei e o dever é a base dos valores familiares. Assim, serão firmados acordos tácitos de constituição familiar. Os papéis de esposa, filho, irmão, com referência no pai, serão perpetuados nos costumes. A racionalidade do homem rural está na prevalência e continuação da tradição do trabalho ligado à terra. As relações econômicas intrafamiliares, a hierarquia entre seus membros, as diferenças de tratamento pertencem a uma ordem que orbita a produção agrícola e pecuária (HEREDIA, 1978). Nesse caso, a corrente que liga as gerações da família à terra é a mesma que os prende enquanto laços familiares, de modo que o poder e os privilégios se sustentam no trabalho, em austeridade, e no amor, em desmedida. A convivência destes contrários justifica a impossibilidade da paz, mediante a irrefreável vontade que habita os corpos, de onde se insinuam sentimentos contraditórios.

Pedro critica a felicidade ilusória que André, aparentemente, buscara fora dos limites da casa e revela o "rosto acabado da família" (NASSAR, 2016, p. 27; LA), insistindo na imagem corporal: "é duro eu te dizer, irmão, mas a mãe já não consegue esconder de ninguém os seus gemidos" (p. 27). O pensamento de André retoma, no eco ancestral, a imagem da queda: "pobre família nossa já desprovida da sua antiga força, e foi talvez, na minha escuridão, um instante de lucidez eu suspeitar que na carência do seu alimento espiritual se cozinhava num prosaico quarto de pensão, em fogo-fátuo, a última reserva de sementes de um plantio” (p. 27). Pedro, fiel aos costumes familiares, busca ponderar e superar o baque da fuga do irmão, tentando 
contornar a derrocada dos valores em provação e penúria pelas quais os valores familiares serão reforçados no momento da superação. Nessa direção, o irmão mais velho tenta converter a imaturidade de André em reflexão consciente para onde verteria a retomada mais próspera dos valores negados, assinalando crescimento e progresso. Por outro lado, em Ricoeur, veremos o aspecto progressivo da queda radicado na consciência da limitação do homem:

por intermédio de uma ação miraculosa de Deus, o que é queda devém crescimento e progresso; a maldição do paraíso torna-se provação e remédio; logo, é o "quão mais" e o "para" de São Paulo que conferem a sua verdade a esta visão da história segundo a qual o acesso do homem à sua humanidade, a passagem da sua infância à sua maturidade, no plano do indivíduo como no plano da espécie, passam pela tomada de consciência das suas limitações, dos seus conflitos e dos seus sofrimentos (RICOEUR, 2015, p. 293).

Nessa direção, o vacilo de André ao deixar a casa seria uma escolha errada, uma das múltiplas manifestações do imaginário da queda, sendo possível que esse deslize seja ressignificado na consciência do erro, constituindo um aprendizado capaz de reverter o tombo em um levantar progressivo, possibilitando não só a reabilitação como o aprimoramento do irmão torto. Pedro enxerga a partida de André como começo da desunião da família, já o filho arredio vê a desunião no instante da queda, como se a crença no bem e a ereção da lei fosse o prenúncio de sua própria transgressão: “a nossa desunião começou muito mais cedo do que você pensa, foi no tempo em que a fé me crescia virulenta na infância e em que eu era mais fervoroso que qualquer outro em casa" (NASSAR, 2016, p. 28; LA). É a própria existência da lei o que garante a sua transgressão, como é a própria fé o que dá consistência à devassidão de André.

Retomando os aspectos mais vis e sanguinolentos da tradição religiosa, o irmão tresmalhado vasculha nas entranhas da fé as suas contradições" sobre os serviços obscuros da fé, levantar suas partes devassas, o consumo sacramental da carne e do sangue, investigando a volúpia e os tremores da devoção" (p. 28). O fervor e o clamor daquele que crê se farta de seu próprio furor sacrílego, entornando a vontade nos estertores da graça, quando em um deslize esta mesma volúpia se pode achar compreendida na sensualidade visceral do corpo. Assim sendo, os rituais de sacrifício, presentes nos textos religiosos, evidenciam o caráter profano do que é sagrado, mediante o uso da carne, do sangue e da morte.

\footnotetext{
${ }^{46}$ Note-se que, tal como faz o chacareiro em Um copo de cólera, André revela suas estratégias em seu fluxo de consciência, sendo que são a narração e os pensamentos do protagonista os elementos permeados e perturbados pelas memórias afetivas. Nesse caso, a linearidade dos fatos fica suspensa em $L A$, restando aos capítulos da narrativa um estado disperso e inconcluso, pendendo para várias interpretações, a depender de cada ângulo assumido e do confronto com as longínquas memórias pessoais de quem se dispõe a compreender a obra.
} 
Entretanto, "na evolução dualista, o divino se torna racional e moral e rejeita o sagrado nefasto para o lado profano" (BATAILLE, 2015, p. 56). Segundo Bataille (2014), mediante a transição entre o Velho e o Novo Testamento, na tradição judaico-cristã, o desejo carnal passa a figurar no âmbito da transgressão. Desse modo se dá a moralização de tudo aquilo que provém do corpo e da natureza, já que a cisão entre bem e mal, conforme o imaginário da queda, instala a graça na transcendência do corpo pela alma. Ao refazer o caminho cindido, regressivamente, encontramos a ligação entre o sagrado e a carne, reconfigurando a simbólica do mal. Como vemos em Ricoeur, "não se deveria partir da carne, como se ela fosse a raiz do mal, mas pelo contrário, chegar à carne, tal como se chega à flor do mal” (RICOEUR, 2015, p. 160). Avaliação semelhante encontra-se em Durand, que aproxima "os símbolos viscerais da queda e da carne" (DURAND, 2012, p. 108).

Avançamos, ainda no capítulo 5, para a dança como ritual sagrado e familiar. A dança manifesta ambiguidade pois é uma celebração regada de vinho em que o gesto austero da família dá lugar a uma volúpia frenética. As irmãs de André com suas "promessas de amor suspensas na pureza de um amor maior" (p. 31) - como já citado em menção à ingenuidade de Pindorama - perfazem a ligação com o sagrado. Conforme o pensamento de Bataille (2014), o que dá sentido à transgressão é o momento e o contexto de sua realização, pois supõe-se a manutenção do interdito. A transgressão precisa ultrapassar o interdito enquanto ele está visível, uma vez que não pode confrontá-lo. Na economia do desejo de Bataille, o interdito é o mundo do trabalho, profano, que divide, isola, controla e manipula. Já a transgressão é o mundo da festa, o sagrado, onde convivem os opostos, onde a intimidade se faz na viscosidade imprecisa dos sentimentos e das sensações.

O interdito provoca medo e terror ocasionando em sua ameaça constante uma devoção que aprisiona: "essa vontade de extremo perfeccionismo transforma a heteronomia numa obediência integralmente assumida e integralmente desejada; abdicar do livre arbítrio torna-se a afirmação suprema da vontade" (RICOEUR, 2015, p. 140). A supressão da vontade e do egoísmo seria o objetivo deste perfeccionismo digno das tábuas do interdito. Assim sendo, o interdito intimida e a transgressão fascina. A lei paterna gera medo, mas a festa gera encantamento. Pode-se dizer que "há, do tempo ordinário à festa, uma inversão dos valores [...] sob o ângulo econômico, a festa consume em sua prodigalidade sem medida os recursos acumulados no tempo do trabalho" (BATAILLE, 2014, p. 92). O tempo profano é acumulação e comedimento para prover a vida social dos recursos necessários à sobrevivência. $\mathrm{O}$ tempo sagrado da festa, por sua vez, aglutina o consumo excessivo sem retirar o interdito de cena. Deste modo, é na confraternização que o dispêndio se manifesta como parte da própria volúpia 
da graça, uma vez que "a festa é o ponto culminante da atividade religiosa. Acumular e gastar são as duas fases que compõem essa atividade: se partirmos desse ponto de vista, a religião compõe um movimento de dança onde o recuo prepara o salto" (BATAILLE, 2014, p. 92). Na descrição da festa veremos que os símbolos corporais emergem: "braços", "dedos", "mão". A entrada de Ana na roda convoca Dioniso:

\begin{abstract}
e não tardava Ana, impaciente, impetuosa, o corpo de campônia, a flor vermelha feito um coalho de sangue prendendo de lado os cabelos negros e soltos, essa minha irmã que, como eu, mais que qualquer outro em casa, trazia a peste no corpo, ela varava então o círculo que dançava e logo eu podia adivinhar seus passos precisos de cigana se deslocando no meio da roda, desenvolvendo com destreza gestos curvos entre as frutas e as flores dos cestos, só tocando a terra na ponta dos pés descalços, os braços erguidos acima da cabeça serpenteando lentamente ao trinado da flauta mais lento, mais ondulante, as mãos graciosas girando no alto, toda ela cheia de uma selvagem elegância, seus dedos canoros estalando como se fossem, estava ali a origem das castanholas, e em torno dela a roda girava cada vez mais veloz, mais delirante, as palmas de fora mais quentes e mais fortes, e mais intempestiva, e magnetizando a todos, ela roubava de repente o lenço branco do bolso de um dos moços, desfraldandoo com a mão erguida acima da cabeça enquanto serpenteava o corpo, ela sabia fazer as coisas, essa minha irmã, esconder primeiro bem escondido sob a língua a sua peçonha e logo morder o cacho de uva que pendia em bagos túmidos de saliva enquanto dançava no centro de todos, fazendo a vida mais turbulenta, tumultuando dores, arrancando gritos de exaltação, e logo entoados em língua estranha começavam a se elevar os versos simples, quase um cântico, nas vozes dos mais velhos (NASSAR, 2016, p. 32-33; LA, grifo nosso).
\end{abstract}

$\mathrm{Na}$ descrição da performance de Ana fica patente a "peste" como mancha, os "gestos curvos" como desvio ambíguo dos valores, a "selvagem elegância" como conexão com a natureza pagã, o delírio, o tumulto e a exaltação como elementos evocados por uma diabólica graça, capaz de cavar, em seu frenesi, túmulos antigos dos quais sobressaem sopros mediterrâneos em "língua estranha", imiscuindo violência e estertor nas turvas tradições do passado, como o faz a mãe diante do assassinato de Ana, no capítulo 29. A ambiguidade e o furor dionisíaco afetam, inclusive, o pai: "e eu podia imaginar, depois que o vinho tinha umedecido sua solenidade, a alegria nos olhos do meu pai mais certo então de que nem tudo em um navio se deteriora no porão" (p. 34). A visceralidade da dança de Ana se inflama, recuperando a violenta cerimônia dos sacrifícios, na qual se reveste aquele encontro familiar festivo. Imagens corporais e sacras vão compondo uma relação dúbia: "útero", "templo erguido", "vitrais", investindo cada objeto, cada corpo e cada substância da festa em tempero para um caldo viscoso no qual se cozinham os valores familiares.

André, em sua narração, vai se dando conta do amor por Ana e das dores na família, enquanto relembra sua partida. A trajetória circular do protagonista ganha evidência à medida que a distância não consegue suprimir os dramas do passado, de modo que todo caminho 
carrega consigo o estigma dos percalços e das dores de percurso, fazendo da busca externa uma constante procura pelo autoconhecimento. Nessa direção, a pergunta "para onde estamos indo?" (p. 37) do sexto capítulo é respondida com "estamos indo sempre para casa" (p. 38) ${ }^{47}$. Ou seja, não estamos indo a lugar algum; estamos presos em nosso cativeiro interior, o que favorece a culpa como símbolo:

a culpabilidade não pode exprimir-se a não ser através da linguagem indireta do "cativeiro" e da "infecção", herdada das duas instâncias anteriores; ambos os símbolos são então remetidos "para o interior" para poderem expressar uma liberdade que se escraviza a si mesma, se afeta e se infecta através da sua própria escolha (RICOEUR, 2015, p. 170).

A fuga de André simboliza sua busca pela continuidade, sua tentativa de romper o ciclo da culpa se transfere da transgressão para o exílio. Não obstante, o gado vai sempre ao poço, a tentativa de sair do cativeiro está fadada ao fracasso, restando apenas a indiferença como postura que exime, simuladamente, o sujeito da responsabilidade. Não podendo ser o homem completamente indiferente, se mantêm os valores como jogos de poder. Assim, os textos nassarianos narram a entrada do ser humano no universo moral pelo esquema da queda, momento a partir do qual a saída deste universo resultará em fracasso, sob abrigo de um destino implacável. O tempo, algoz invencível, carrega as feridas e os arrependimentos para o abismo inexorável das memórias, projetando no cotidiano a angústia de existir.

Entretanto, a missão de Pedro é a reconciliação, a retomada consciente dos valores perdidos: "tudo vai ser de novo como era antes" (NASSAR, 2016, p. 40; LA), já no sétimo capítulo. A reconciliação, na simbólica do mal, está intimamente ligada ao retorno, ao arrependimento, àquilo que aparece na parábola do filho pródigo:

\footnotetext{
"arrependimento" e "transgressão", ambos pertencem ao mesmo universo temático e, portanto, não é por acaso que foi o judaísmo a enfatizar o conceito de "arrependimento"; isto porque o "arrependimento" significa que o retorno do livrearbítrio a Deus depende sempre dos homens; o exemplo dos grandes ímpios que "voltaram" para o Senhor está lá para atestar que é sempre possível que o homem "mude de caminho". Essa ênfase colocada no arrependimento está em conformidade com a interpretação da "inclinação má" como ocasião de pecado e não como mal radical [...] o "perdão" nunca é negado ao "arrependimento", nem a graça à boa vontade (RICOEUR, 2015, p. 148).
}

Não obstante, Raduan formula um caminho em direção a uma graça inalcançável, uma eterna circunvolução do sujeito em torno de si mesmo em busca da terra mãe, da continuidade

\footnotetext{
${ }^{47}$ As frases são citações literais de Novalis (1942). Para uma leitura desta relação intertextual e intercultural consultar Lemos (2010b).
} 
perdida, da recuperação de uma paz idílica e confortante na intimidade do útero materno. Porém, não é possível se abster do inconveniente de se ter nascido, já que o homem acaba por se apegar a sua situação de ser descontínuo. Pensando com Bataille (2014), mesmo com a busca premente e obsessiva pela continuidade - o percurso do erotismo - o homem não deseja abandonar-se à morte, mas simular e experimentar a situação de morte na sexualidade corporal e literária. Matar o outro é seduzí-lo, dominá-lo e profaná-lo, assasiná-lo simbolicamente mediante a violação. A androginia do erotismo garante, por outro lado, que ao matar o outro se esteja também matando a si próprio, o que sugere a pulsão de morte da psicanálise freudiana.

A conversão da pulsão de vida que a terra entrega nas colheitas é vertida, a partir de sua ambivalência, na pulsão de morte que conforma no romance uma feminilidade misteriosa e virulenta. Nesse caso, na composição dos fios do destino concorre a semeadura de grãos nefastos e perversos, amalgamando os tecidos que vestem e os véus que encobrem a indiscernível interioridade da mãe, correspondente tanto à origem divina do nascimento quanto a corrupção do ato sexual nele implícito. Nestes termos, em $L A$, a mãe aparece como expectadora de uma conciliação impossível:

pude vê-la sentada na cadeira de balanço, absolutamente só e perdida nos seus devaneios cinzentos, destecendo desde cedo a renda trabalhada a vida inteira em torno do amor e da união da família, e vendo o pente de cabeça em sua majestosa simplicidade no apanhado do seu coque eu senti num momento que ele valia por um livro de história (NASSAR, 2016, p. 40-41; LA).

A homologia entre os fios e os caminhos projeta nos tecidos a corrente da vida, de modo que o tempo e a história cobrem e confundem as trilhas do destino, fazendo do habitat da memória um arquivo em que se guarda em gaveta insuspeitada os tenebrosos segredos familiares, tão ocultos quanto evidentes a todo momento, colocando em furor os corpos que padecem nas vestes da mãe e suas tessituras: "os instrumentos e os produtos da tecedura e da fiação são universalmente simbólicos do devir. Existe, de resto, constante contaminação entre o tema da fiandeira e o da tecelã, este último repercutindo por outro lado nos símbolos do traje, do véu" (DURAND, 2002, p. 321).

Na sequência do diálogo do sétimo capítulo, Pedro revela a reação de Ana à partida de André: "ninguém em casa mudou tanto como Ana" (p. 41). As palavras de Pedro sobre Ana provocam grande impacto no irmão desviado: "eu vi que meu quarto de repente ficou escuro, eu só conheci aquela escuridão" (p. 41). Nos capítulos iniciais, enquanto Pedro descreve as consequências da partida de André para a família, o protagonista tateia em suas memórias a lembrança de todo o trajeto que o transformou no filho acometido, de modo que há um conflito 
eminente entre a moral enquanto ente regulador do convívio social e a ética, enquanto critério particular e individual de leitura de mundo. Nesse caso, André rechaça e inverte a moral vigente a partir de sua própria linguagem, como quem quer provar que há no sustentáculo da ordem o arbítrio da autoridade. Enquanto Pedro conta o cenário da família parafraseando os sermões paternos, André prepara o contra-ataque. O desabafo se inicia com a descrição da reação dos familiares à sua condição de "epilético", quando os "homens da família" pregaram cruzes de madeira nas portas e janelas condenando o irmão por sua doença: "traz o demônio no corpo" (p. 44). André fermenta sua vingança na memória da violência paterna:

era ele, Pedro, era o pai que dizia sempre é preciso começar pela verdade e terminar do mesmo modo, era ele sempre dizendo coisas assim, eram pesados aqueles sermões de família, mas era assim que ele os começava sempre, era essa a sua palavra angular, era essa a pedra em que tropeçávamos quando crianças, essa a pedra que nos esfolava a cada instante, vinham daí as nossas surras e as nossas marcas no corpo, veja, Pedro, veja nos meus braços (NASSAR, 2016, p. 45; LA).

A memória da rigidez paterna, as palavras marcadas pelo dever e pelo trabalho, a violência da austeridade: elementos de um conjunto de valores articulados pela linguagem e desaguando nos corpos à maneira de surras e violentas correções. Porém, junto à palavra do pai havia uma atmosfera de ambivalência na casa, nos gestos, na força rudimentar de cada um. A ambiguidade resvala nas roupas da família, de modo que a abrangência dos valores paternos se manifesta em cada elemento e cada objeto da casa, atravessando todos os sentidos de seus moradores e sufocando vozes dissonantes que se insinuam a partir de fístulas purulentas:

era preciso conhecer o corpo da família inteira, ter nas mãos as toalhas higiênicas cobertas de um pó vermelho como se fossem as toalhas de um assassino, conhecer os humores todos da família mofando com cheiro avinagrado e podre de varizes nas paredes frias de um cesto de roupa suja; ninguém afundou mais as mãos ali, Pedro, ninguém sentiu mais as manchas de solidão (NASSAR, 2016, p. 47; LA).

É no cesto de roupas sujas que os tecidos e os caminhos se reúnem preservando a peculiaridade das vestes preparadas na própria fazenda pela mãe e, todavia, salvaguardando os fluídos da menstruação das meninas, de eventuais feridas do trabalho ou das surras, da excreção, do suor e, sem dúvida, os caldos entornados nas vestes íntimas, oriundos da impetuosidade dos prazeres sexuais reprimidos. Este conteúdo funesto dá vazão a torrente de contradições que convivem com a austeridade paterna, ajustando nas entranhas da arquetipologia do feminino os espaços desapercebidos em seu turbilhão de emoções e sentimentos.

A denúncia de André chega, na sequência, à figura do avô, que simboliza o veio ancestral ligado ao devir, ao destino. A transição do modelo do avô à palavra paterna combinada 
ao amor materno abre o lastro à transgressão do protagonista: "o mundo pra mim já estava desvestido, bastava tão só puxar o fôlego do fundo dos pulmões, o vinho do fundo das garrafas, e banhar as palavras nesse doce entorpecimento" (p. 49). André insiste na inconsistência dos sermões do pai que tergiversavam a imagem do avô. O relógio, acompanhando a figura do avô, ao fundo da mesa dos sermões é o símbolo do tempo, do destino e sua implacabilidade, a figura de Cronos devorador.

O capítulo 8 compõe-se de imagens da vegetação e seus fenômenos cíclicos. A conexão entre os elementos naturais e os sentidos corporais se desenha como em um tempo avesso aos sermões, à guisa de Kairós. André deseja, mediante sua conexão com a terra, refundar e reordenar o tempo para, com isso, reorganizar a existência e refazer a economia do desejo em seu favor, de modo que a pletora dos sentidos encontrasse sua plenitude no alvoroço dos “mensageiros mais velozes" de um mundo composto por formas sensuais e lubricas.

O sermão paterno se manifesta no nono capítulo delimitando o caminho a ser seguido longe das paixões, com paciência, fidelidade e dever. A lei paterna procura, por meio da ascese, impedir que os corpos sejam tomados pelos ímpetos instintivos, pela potência da vontade irracional, que não se deixa governar. A privação é, portanto, o mecanismo de defesa para a sobrevivência do grupo social:

só chega a este raro resultado aquele que não deixa que um tremor maligno tome conta de suas mãos, e nem que esse tremor suba corrompendo a santa força dos braços, e nem circule e se estenda pelas áreas limpas do corpo, e nem intumesça de pestilências a cabeça, cobrindo os olhos de alvoroço e muitas trevas (NASSAR, 2016, p. 58; LA).

André se opõe aos valores da família, sucumbe às paixões, é impaciente e vadio, porém, sua oposição vai perdendo a simetria que teria com a lei paterna à medida que o terceiro incluído vai se insinuando na (est)ética nassariana, de modo que $L A$, como nenhum outro de seus textos, quebra dicotomias não mais no movimento espiralado das contradições, mas na imensidão terral do rizoma, proliferando ausências e incômodos em raízes tão fundas quanto díspares e dispersas.

O capítulo 10 apresenta os objetos da família. Escrito entre parênteses, aparece como interlúdio ou música incidental para a conversa entre André e Pedro, assim como o são outros capítulos desta primeira parte do livro: ora Pedro está dialogando com André no quarto de pensão, retomando a história da família, ora o narrador nos lança em descrições e lembranças que vão construindo uma constelação de símbolos que edificam uma história passional no intercurso da família patriarcal. As imagens do décimo capítulo são: “vidros”, "metais”, "areia”, 
“pó”, “pedra”, “pilão”, “socador”, “varais”, “gamela”, “caneca”, “moringa”, “torrador de café”, "panelas", "cumbuca", "latão", "ferro de passar", "bule de ágata", "fogão à lenha”, "tacho", "chaleira de ferro", "louça", “cabide”, "porta retrato", "fotografia".

Note-se que as substâncias ornam com os utensílios para preparação dos alimentos, estes ligados também aos objetos e utensílios para cuidar das roupas da família, não nos esquecendo da foto do grupo inteiro, constelando em torno de cada corpo material naquela casa como uma raiz corrompida pelo lastro das memórias afetivas, guardando em sua relação com o sagrado a obscuridade que advém pela cisma entre Ocidente e Oriente, às margens do Mediterrâneo. Nesse contexto, a família patriarcal concentra a autoridade nas mãos do pater, o patriarca, que manifesta seu domínio sobre a esposa, os filhos e a fazenda (HEREDIA, 1978). O pai detém o poder de decisão e a posse dos bens da família. A mulher é submissa, ocupa posição secundária nas atividades. Ao filho mais velho é concedida a missão de perpetuar o nome e as posses do pai. Estes preceitos são compreendidos tacitamente e é esperado que sejam absorvidos espontaneamente através de cada peça e cada contorno desenvolvido no ambiente familiares, de maneira que o patriarcalismo esteja incorporado nos alimentos, nas vestes, nos utensílios domésticos, nas paredes, em cada gesto e cada gota de suor derramada em favor do trabalho.

No capítulo 11 André destila ódio. Retoma a ancestralidade reintroduzindo o mito de origem nos seus termos. Brada sobre a mãe: "eu e a senhora começamos a demolir a casa" (NASSAR, 2016, p. 70; LA). Não seria, afinal, na partida de André que a desunião da família começou. Seria, para o protagonista, a própria cisão bem e mal que inaugura a alienação do sagrado e a separação da família, o que localiza a corrupção não em sua atitude desviante, mas na própria edificação dos valores, que prevê de antemão o fenômeno de sua ruptura. A vontade violenta e o erotismo de André simbolizam a recuperação do sacrifício, a tentativa de desinvestir a austeridade asséptica e retomar em Kairós um instante em que tesão e sagrado pertencem a um mesmo laço de potência erótica.

Pensando com Bataille (2014), considera-se que a experiência mística é a manifestação do erotismo sagrado pois ela tende à continuidade do ser sem a necessidade de um objeto. $\mathrm{O}$ erotismo sagrado será, enfim, a indiferença diante da morte: "a aprovação da vida até na morte é desafio [...] ela é desafio, por indiferença, à morte. A vida é acesso ao ser: se a vida é mortal, a continuidade do ser não o é. A aproximação e a embriaguez da continuidade dominam a consideração da morte" (BATAILLE, 2014, p. 22, grifo nosso). Nesse caso, no "erotismo sagrado", que constela com o "erotismo corporal" e o "erotismo dos corações", se alcança a conformação sublime e grotesca de um instante eterno, capaz de aglutinar as experiências de vida e morte a um só tempo. 
A trajetória de André, homóloga à fuga de Caim, é o percurso interior de retomada da experiência do sagrado vivida na infância com o fervor religioso, os carinhos maternos e o senso de proteção da família e da casa. A descontinuidade é, então, percebida na adolescência, sobretudo no despertar sexual, tal como no drama edipiano de Freud e Lacan (MASOTTA, 1989; LESOURD, 2004), incorrendo em ausência ou falta ${ }^{48}$. A intimidade sagrada do seio familiar é rompida pelos acessos da vontade impetuosa. Portanto, não se trata de uma viagem de sonhos, solar, mas uma viagem de angústia cativa, em trevas.

provocando as suspeitas e os temores na família inteira, não era com estradas que eu sonhava, jamais me passava pela cabeça abandonar a casa, jamais tinha pensado antes correr longas distâncias em busca de festas pros meus sentidos; entenda, Pedro, eu já sabia desde a mais tenra puberdade quanta decepção me esperava fora dos limites da nossa casa (NASSAR, 2016, p. 71; LA).

A consciência do protagonista se conforma, de largada, com o arremedo da culpa, já que sua busca errante fora dos limites da fazenda foi senão uma explosão interna, conquanto a tentativa de transmutação dos valores já se sabia com destino falho no pensamento de André, o que amplia o sufoco a o aprisionamento das narrativas nassarianas para a própria dimensão filosófica da temporalidade e para a materialidade sinestésica do corpo e da natureza, confrontando referências de toda ordem para confirmar a aventura prisioneira dos dramas humanos.

André segue contando que roubava dinheiro do pai para frequentar, longe da fazenda, casas de prostituição. A partir de então são erigidas imagens teriomórficas, já que o discurso do narrador-personagem André vai ganhando peso e contrapondo a ordem paterna. Evocando símbolos animais, André principia a inversão característica do regime noturno: "patas", "piolhos", “formigas", "borboletas", "larvas", “insetos", “escaravelhos". Segundo Gilbert Durand, "os símbolos botânicos que suscitam o arquétipo da paixão do Filho vão acarretar um simbolismo teriomórfico com tanto mais facilidade quanto o ciclo comporta [...] uma fase noturna e nefasta, como que predestinada à teriomorfia" (DURAND, 2002, p. 312). A dinâmica de transição entre imagens vegetais e de animalidade sugere que o simbolismo de intimidade materna vai sendo substituído pela inversão, pela transmutação de valores que André tenta ao

\footnotetext{
${ }^{48} \mathrm{Na}$ psicanálise lacaniana a falta ocupa um papel central, sendo a partir dela que se dá a pulsão erótica em busca de uma satisfação jamais alcançada, fazendo da sustentação constante do desejo um caminho aprazível. No entanto, do mesmo modo que podemos interpretar a ausência interna se projetando em busca do que a complemente, podemos interpretar o procura desta completude como um excesso interno que almeja conexões com o excesso externo do mundo, configurando a vontade em relações díspares de encontro e desencontro entre corpos e linguagens.
} 
transgredir o simbolismo heroico e progressista da palavra paterna. Entretanto, no capítulo 12 André profana o pão, contesta a austeridade do alimento familiar sagrado:

\footnotetext{
nunca tivemos outro em nossa mesa que não fosse o pão-de-casa, e era na hora de reparti-lo que concluíamos, três vezes ao dia, o nosso ritual de austeridade, sendo que era também na mesa, mais que em qualquer outro lugar, onde fazíamos de olhos baixos o nosso aprendizado da justiça (NASSAR, 2016, p. 82; LA).
}

O narrador-personagem enxerga naquele alimento a miséria dos valores. O pão é alimento espiritual, mas é também o "corpo de Cristo", amalgamando alma e corpo no combustível diário da família. Nessa direção, reforça o sentido da aliança do homem com a divindade, o pai, Iohána (João; agraciado por Deus), é o profeta, o porta-voz, da vontade de Deus e de sua justiça colérica e misericordiosa, entendidos como tábua de valores transcendentes que amparam o código familiar de conduta. Nesse caso, Deus é simbolicamente apresentado como a própria força dos preceitos morais, como ordem natural de uma vontade celeste e reluzente com a qual se conformaram gerações e gerações em torno da lavoura agrícola e expressiva daquele grupo familiar. Dito de outro modo, a divindade entra não como o Deus cristão ou islâmico em si, mas efetivamente no conjunto de valores familiares amparados na tradição e na razão, impregnando o cotidiano com a lei paterna e materializado o aprendizado milenar em cada objeto da casa, o que projeta o termo "arcaico" para um tempo recuado na história, sem perder a característica de anterioridade fenomenológica, como espaço de conformação de valores, e ontológica, radicando nas tenras vivências infantis o ambiente profícuo para a semeadura daquela "lavoura".

A comunhão com Deus, ou com os valores familiares, se dá sempre, portanto, na "tensão entre uma exigência infinita e um mandamento finito" (RICOEUR, 2015, p. 72, grifo nosso). Assim sendo, embora os valores sejam clara e finitamente definidos nos sermões, a moral se obscurece ao se perder na infinitude de possibilidades de interpretações e situações de aplicação destes valores. Ou seja, a onipotência da moral familiar faz do homem um eterno penitente. Não obstante, a exigência implacável da divindade, ao se materializar em lei - em $L A$, nos sermões - se apresenta como ciúmes: o detalhamento das interdições pecaminosas na matéria das leis nunca é suficiente ao Deus e o pecador sempre está em falta, inexoravelmente abandonado à errância:

Deus se revela como sendo o mestre que repudia. Esse símbolo do repúdio é assustador: anuncia que o homem é abandonado pela própria ausência de Deus, que é instituída por Deus; essa ausência de Deus, segundo Oséias, já é o desamparo dos 
modernos, isto é, uma insegurança e uma angústia ainda piores do que o sofrimento (RICOEUR, 2015, p. 73).

Se a exigência de Deus, da moral familiar, é infinita e as leis finitas, o pecado também se múltipla à toda sorte de transgressões, o espírito das leis segue inaugurando novos pecados que surgem à sua imagem e semelhança: "a lei é um "pedagogo" que ajuda o penitente a determinar o seu modo de ser pecador" (RICOEUR, 2015, p. 76). Assim, em LA, é André quem se percebe e percebe a família em desamparo, preservando uma intensa e constante angústia na vida corrente. O tormento é tão implacável que nem mesmo a explosão do filho tresmalhado o tornará imune à corrente que liga e prende, a um só tempo, reforçando uma danação agonística, em que os membros da família se debatem sob o manto de um destino pesado. Por outro lado, não é demais ressaltar que entre a exigência infinita da moral e os mandamentos finitos dos valores vem se somar o halo entre a frugalidade e o dispêndio.

A parábola do faminto aparece no capítulo 13. Sua máxima é a virtude da paciência; a espera e a obediência. A infinita fome do miserável será saciada pela paciência esperançosa de graça e salvação. O dinamismo entre comedimento e dispêndio é atributo da misericórdia. A vocação para o pecado do homem será redimida pelo perdão do segundo Adão, Jesus Cristo, imagem de todos os homens. Se o Deus colérico dos profetas era vingador e ciumento, Cristo, à imagem do pai, reitera a esperança histórica que se orienta pela escatologia da salvação. Ou seja, a danação do pecador se redime pela sua obediente espera na promessa. Há, aqui, a marca formativa que separa a pedagogia do pai da deseducação de André:

\footnotetext{
Essa pedagogia do excesso e do aumento que, da abundância do pecado faz a superabundância da graça, não está à disposição de ninguém; ninguém a pode transformar em técnica e pretender pecar abundantemente para que a graça superabunde. É só retrospectivamente que a consciência libertadora reconhece, no estádio ético, que é vivido como escravatura, o caminho tortuoso da sua libertação; mas não é possível inverter o paradoxo que é irreversível numa qualquer técnica que fizesse da cultura do pecado o melhor meio para alcançar a graça: esse satanismo mais não seria do que a forma mais sofisticada da empresa ética; isto porque ele ainda seria, para o homem, vangloriar-se em si mesmo e por si mesmo, como fazia através do rito e da lei (RICOEUR, 2015, p. 166-167).
}

A pedagogia cristã da humildade é traduzida em pedagogia da humilhação no espírito dionisíaco de André, de modo que a satanologia descrita no trecho de Paul Ricoeur é justamente a opção do filho arredio, imiscuindo a graça em uma profusão de pecados e heresias, conquanto essas possam ser o prenúncio de um perdão ainda mais fervoroso, desde que o arrependimento seja correspondente em intensidade aos atos pecaminosos. Em resposta ao ascetismo e a austeridade da parábola do faminto, André reintegra o avesso daquela estória à ordem do dia: 
"o faminto - com a força surpreendente e descomunal da sua fome, desfechara um murro violento contra o ancião de barbas brancas e formosas" (NASSAR, 2016, p. 88; LA) ${ }^{49}$. O filho tresmalhado pretende, afinal, inverter os valores apregoados pelo pai, reintroduzindo a impaciência, a violência e o imediatismo nas próprias palavras sagradas. Prosseguindo em direção ao décimo quarto capítulo, o protagonista sustentará o amor fati e a segunda metamorfose do Zaratustra nietzscheano - o leão diz "eu quero" (NIETZSCHE, 2011). É o anúncio da virada de André como anti-herói.

\begin{abstract}
pela primeira vez senti o fluxo da vida, seu cheiro forte de peixe, e o pássaro que voava traçava em meu pensamento uma linha branca e arrojada, da inércia para o eterno movimento; e mal saindo da água do meu sono, mas já sentindo as patas de um animal forte galopando no meu peito, eu disse cegado por tanta luz tenho dezessete anos e minha saúde é perfeita e sobre esta pedra fundarei minha igreja particular, a igreja para o meu uso, a igreja que frequentarei de pés descalços e corpo desnudo, despido como vim ao mundo, e muita coisa estava acontecendo comigo pois me senti num momento profeta da minha própria história, não aquele que alça os olhos pro alto, antes o profeta que tomba o olhar com segurança sobre os frutos da terra, e eu pensei e disse sobre esta pedra me acontece de repente querer, e eu posso! (NASSAR, 2016, p. 91-92; LA, grifo nosso).
\end{abstract}

As imagens do "cheiro de peixe" e "água do meu sono" demandam a imersão no inconsciente, de onde, por meio da sinestesia se reinterpreta os valores familiares projetando o caldo passional dos sentidos na arrazoado racional da palavra ancestral de comedimento, alimentando as vísceras da passionalidade com a cegueira desta luminescência. Sem se afastar das próprias premissas de Iohána, o filho pródigo confirma a leitura do pai de que "aqueles que abrem demais os olhos acabam só por ficar com a própria cegueira” (p. 171). Ao observar com seus próprios olhos a natureza ao seu redor, André, ao mesmo tempo, confere uma leitura autêntica ao mundo em seu entorno e enxerga aquilo que quer ver, manifestando seu desejo pessoal naquilo que enuncia como verdade. Se, por um lado, a visão do filho corrompe a ideia de uma verdade asséptica, isolando o fenômeno do observador, por outro, a esperança de que este olhar permeado de paixões seja, afinal, a verdade é frustrada mediante a ação do trágico, impossibilitando ao homem a apreensão definitiva do que é real.

Dando sequência à narrativa de Nassar, no capítulo 15 André reinterpreta o avô como figura divina, projetando nele um conjunto de símbolos que convergem para Cronos, para o Deus cristão ou islâmico, para o trágico, para o destino, sendo a ausência de palavras a sua aderência às formas da natureza, de onde emergem perigos tão excitantes para o filho torto,

\footnotetext{
${ }^{49}$ No filme de Luiz Fernando Carvalho, Lavoura arcaica (BRA-2001), o ancião de barba branca, homem muito rico, é interpretado por Raul Cortez, que atua também como pai de André, Iohána, naquela película.
} 
posto que se André vê no avô o ferrete do tempo e da austeridade paterna, nele também vê o curso natural da vida, com o qual se pode recuperar o erotismo sagrado em uma temporalidade cíclica. Nessa direção, simetrias são adornadas na visão de André: o pai como profeta, o avô como divindade, personificando o destino colérico e implacável, Pedro como a pedra angular dos valores familiares; a mãe como o mistério das origens, André como a condição do homem, Ana sua face sensual e perversa, Lula, o sopro de continuidade do ciclo interdito-transgressão, Rosa, Zuleika e Huda, o silêncio da mulher, quase fundidas à casa e à família. Cada membro daquela família possibilita um paralelo com figuras da tradição religiosa humana, tornando mais evidente quanto mais suprimidas as referências evocadas por Nassar, o que traz densidade à narrativa, ao passo que é o próprio leitor quem necessita apelar ao seu repertório inteligível e sensível para fruir a trama passional da família.

No capítulo 16 André simboliza sua transgressão ancestral em sinergia com os “mensageiros mais velozes" da infância, sensibilidade e sensualidade, revelados em paganismo. A "natureza tida por maligna" (NASSAR, 2016, p. 94; LA), o "apetite mórbido e funesto" (p. 95) faz André sentir duas enormes mãos debaixo de seus pés. Estas mãos que orientam, impelem, aprisionam e governam o que não tem governo, mãos que carpem no mesmo tempo em que afagam, tangenciando as imagens do pai e da mãe na economia de um destino forte. A reconstrução do sagrado redirecionado e invertido na transgressão incestuosa: "que paixão mais pressentida, que pestilências, que gritos!” (p. 96). A fé invertida de André segue no décimo sétimo capítulo: capturar a pomba é demonizar o próprio Espírito Santo, é ter Ana em seus braços. O verbo austero do tempo traz a brandura de ecos orientais:

\footnotetext{
O tempo, o tempo é versátil, o tempo faz diabruras, o tempo brincava comigo, o tempo se espreguiçava provocadoramente, era um tempo só de esperas, me guardando na casa velha por dias inteiros; era um tempo também de sobressaltos, me embaralhando ruídos, confundindo minhas antenas, me levando a ouvir claramente acenos imaginários, me despertando com a gravidade de um julgamento mais áspero, eu estou louco! (NASSAR, 2016, p. 97; LA).
}

André, com sua ciência de menino (recuperando o obscuro de sua fé infantil), deseja capturar a pomba, capturar o amor de Ana. A pomba, na cultura cristã, simboliza o Espírito Santo, estado de sagração absoluta: "quanto à pomba, pássaro de Vênus, se aparece muitas vezes implicada num contexto sexual, e mesmo ctônico, não deixa por isso de ser o pássaro do Espírito Santo [...] Se desempenha um papel sexual na mitologia cristã, esse papel é nitidamente sublimado" (DURAND, 2012, p. 132). É, precisamente, na sublimação, em seu sentido tão psicanalítico quanto escatológico, que a verborragia de Ana se anuncia em todas as palavras do 
romance, fundindo a graça e a pureza do feminino na manifestação terral da natureza. Em entrevista, Raduan comenta a personagem Ana: "de fato, ela não abre a boca, se bem que os lábios formigam... De qualquer forma, mesmo sem abrir a boca, Ana chegaria quase à loquacidade" (NASSAR, 1983, p. 103).

A transmutação de valores de André carrega no cerne da trindade, carnavalizando o divino, demonizando o sagrado. A virulência devolve ao erotismo sua violência transgressora, como apontado em Bataille (2014). Diante do hibridismo cultural, especialmente em LA, a escolha dos nomes dos personagens possui apelo singular ${ }^{50}$. André é o andros, o homem, a própria condição humana. Ana, do hebraico, graça, e eu em árabe. O Espírito Santo bemaventurado de um lado, a outra face do próprio André (o feminino sensual do eu) do outro. Pedro, a rocha, a pedra basilar da Igreja Primitiva ${ }^{51}$.

André tenta manipular o tempo no capítulo 18, em que descreve a captura da pomba: "fechei a porta, tinha puxado a linha, sabendo que ela, em algum lugar da casa, imóvel, de asas arriadas, se encontraria esmagada sob o peso de um destino forte" (NASSAR, 2016, p. 105; LA). O protagonista inicia uma cínica veneração de Deus, na esperança de que o ser supremo atenda os desígnios de seu corpo. Os pronomes possessivos são escritos em letras maiúsculas, endereçados a Deus. Ana entrou na casa velha, Ana está na palha. É tempo de espera, de paciência, é tempo de consumar o ato funesto.

\footnotetext{
Deus existe e em Teu nome imolarei um animal para nos provermos de carne assada, e decantaremos numerosos vinhos capitosos, e nos embriagaremos depois como dois meninos, e subiremos escarpas de pés descalços (que tropel de anjos, que acordes de cítaras, já ouço cascos repicando sinos!) e, de mãos dadas, iremos juntos incendiar o mundo! (NASSAR, 2016, p. 110; LA).
}

Neste ponto, a subversão da parábola bíblica se concretiza em incesto. O sacrifício que, na cultura judaico-cristã, está ligado à expiação, ao perdão, é, aqui, tomado como recompensa da transgressão carnal. Se no texto bíblico é a redenção que leva o pai a imolar um animal, aqui é uma liturgia sensual que recupera a dimensão do sagrado. Para Bataille (2014), o sacrifício é a experiência máxima da transgressão, possibilidade enérgica de ligação do ser à continuidade sagrada, já que simboliza a própria experiência de morte. O paganismo insurgente das imagens evocadas por André desagua em sacrifício: “é igualmente isomórfico do definhamento

\footnotetext{
${ }^{50}$ Consultar os trabalhos “A tra(d)ição dos nomes na Lavoura arcaica, de Raduan Nassar”, de Regina Céli Alves da Silva (2003), e "A história nos nomes: patriarcalismo em lavoura arcaica, de Raduan Nassar", de Leandra Postay (2013).

51 Também os nomes das outras irmãs expressando uma encantadora feminilidade: Rosa (bela flor), Zuleika (brilhante, beleza radiante) e Huda, variação de Hulda (segredo).
} 
agrolunar o ritual dos sacrifícios. Os sacrifícios humanos são universalmente praticados nas liturgias agrárias" (DURAND, 2002, p. 308). A menção ao sacrifício e até mesmo o incesto como uma forma de sacrifício reforçam o movimento de inversão formulado por André.

Pensando com Bataille (2014) e Ricoeur (2015), o cristianismo opõe-se à transgressão. O esvaziamento do erotismo é caro ao cristianismo, que retira a violência do âmbito do sagrado profanando-a como mancha, pecado, culpa, moralizando a potência erótica às custas do interdito. Para que a violência assumisse um estatuto moralmente negativo, foi necessário que o mundo divino se aproximasse do mundo terreno e essa aproximação se deu, efetivamente, pelo trabalho:

\footnotetext{
O mundo organizado do trabalho e o mundo da descontinuidade são um só e mesmo mundo. Os instrumentos e os produtos do trabalho são coisas descontínuas. Aquele que se serve do instrumento e fabrica os objetos é também um ser descontínuo, e a consciência de sua descontinuidade se aprofunda no emprego ou na criação de objetos descontínuos. É em relação ao mundo descontínuo do trabalho que a morte se revela: para os seres cujo trabalho revelou a descontinuidade, a morte é o desastre elementar que põe em evidência a inanidade do ser descontínuo (BATAILLE, 2014, p. 144, grifo nosso).
}

Primeiro a premissa de que a descontinuidade é a essência do ser, posteriormente, a promessa do reencontro da descontinuidade na imortalidade. O cristianismo reduziu o sagrado a um Deus criador descontínuo num céu e num inferno, povoado de seres descontínuos em danação eterna. A busca desse amor recíproco entre Deus e os eleitos (o povo de YHWH) conduziu o sagrado a uma condição de espera pela conciliação. A expulsão do Anjo Mal do mundo divino é o mito que orienta este movimento. A transgressão passaria ao mundo profano, isolada do sagrado. Durand (2012), Bataille (2014) e Ricoeur (2015) concordam que são o mito adâmico e o esquema de queda os elementos da moral cindida entre bem e mal, localizando a transgressão na negatividade. Em outra direção, retomando a paixão incestuosa, a experiência do narrador-protagonista é precisamente descrita por André Luis Rodrigues:

A promessa de André é uma diabólica inversão de papéis: a devolução da vida ao próprio Deus e justamente por aquele que afirmava a própria descrença ('um milagre, um milagre, meu Deus, eu pedia, um milagre e eu na minha descrença Te devolvo a existência'). Além disso, o que se percebe nessa prece blasfema, que é quase um delírio, é a impossibilidade de pensar a relação com a divindade de uma forma incorpórea, abstrata. Deus aqui é o Deus feito homem, feito carne. Mistura-se, nas palavras que jorram incessantemente de sua boca, o que poderia ser uma alusão a uma imagem qualquer de Cristo ao que só pode ser alusão a um corpo vivo, pleno de artérias e de pelos (RODRIGUES, 2006, p. 83-84). 
Retirando o sagrado de sua condição celeste, André aponta a transgressão para a terra, refazendo a lavoura na manifestação carnal de um "corpo vivo", como nos mostra Rodrigues. Não é demais pensarmos que ao retirar Deus de seu paraíso celeste e descontínuo, o filho virulento recompõe sua manifestação em seu próprio corpo, fazendo de si a própria divindade, capaz, afinal, de autorizar a si mesmo em sua vontade incontornável. Ao refazer Deus em si mesmo, o protagonista flerta com a perspectiva do sagrado adotada no Oriente, ao mesmo tempo que alcança o tom profético do Zaratustra nietzscheano.

No capítulo subsequente André confessa a paixão por Ana: “era Ana, era Ana, Pedro, era Ana a minha fome [...] era Ana a minha enfermidade, ela a minha loucura, ela o meu respiro, a minha lâmina, meu arrepio, meu sopro, o assédio impertinente dos meus testículos" (NASSAR, 2016, p. 111; LA). No mesmo capítulo 19 o protagonista manifesta a potência da inversão, da transmutação de valores:

\begin{abstract}
eu tinha de gritar em furor que a minha loucura era mais sábia que a sabedoria do pai, que a minha enfermidade me era mais conforme que a saúde da família, que os meus remédios não foram jamais inscritos nos compêndios, mas que existia uma outra medicina (a minha!), e que fora de mim eu não reconhecia qualquer ciência, e que era tudo só uma questão de perspectiva, e o que valia era o meu e só o meu ponto de vista, e que era um requinte de saciados testar a virtude da paciência com a fome de terceiros (NASSAR, 2016, p. 113; LA).
\end{abstract}

Além das ralações com o chacareiro de $C C$, em sua "missa negra" (NASSAR, 2016, p. 248; CC), neste trecho, o texto se impõe como palavra dos excluídos, universo que fica à margem dos sermões do pai: "eu só estava pensando nos desenganados sem remédio, nos que gritam de ardência, sede e solidão, nos que não são supérfluos nos seus gemidos; era só neles que eu pensava" (NASSAR, 2016, p. 167; LA). André e o chacareiro são personagens que vão longe na transmutação moral, através do discurso. Não só questionam em atos e palavras a ordem vigente, mas insinuam sua própria Igreja, sua própria ciência, sua própria educação, sua própria moral; a liberdade radicada na performance discursiva.

A mais-valia com a qual o filho tresmalhado conta vantagem sobre o pai se deve a percepção de que o olhar nunca é neutro, mas sempre povoado de sentimentos e preferências de quem vê, o que leva o adolescente André a pensar que "uma planta nunca enxerga a outra" (p. 164). Além disso, segundo André, a "fome de terceiros" não deve se prestar a parábolas sobre a paciência, posto que a lavratura das leis se conforma alheia ao ímpeto dos corpos que se contorcem em seu excesso. Nesse caso, é a culpa o que faz André achar "um triste faz de 
conta viver na pele de terceiros" (p. 166). Ou seja, é mediante o refrear das pulsões que se dá o contrato social, projetando o interdito no superego a partir dos desejos de outrem.

Para recriar a ordem postulando a virulência absoluta da desmedida em um tempo de consternação total dos sentidos, o filho recorre à condição de excluído, lançando mão do poder da vítima e sua descomunal capacidade de cativar por meio de suas reivindicações rebeldes. André, então, desenha a figura de Anjo Mal mediante o símbolo teriomórfico de cavalo do apocalipse, Lúcifer, o mestre dos excluídos:

redescobrindo sem demora em mim todo o animal, cascos, mandíbulas e esporas, deixando que um sebo oleoso cobrisse minha escultura enquanto eu cavalgasse fazendo minhas crinas voarem como se fossem plumas, amassando com minhas patas sagitárias o ventre mole deste mundo, consumindo neste pasto um grão de trigo e uma gorda fatia de cólera embebida em vinho, eu, o epilético, o possuído, o tomado, eu, o faminto (NASSAR, 2016, p. 113-114; LA).

A intenção performática de André fica patente, de modo que sua cavalgadura implica a tentativa de romper com toda a lavoura arcaica, em todos os sentidos previstos na abundância de interpretações que se possa arrolar para estas duas amplas palavras. Porém, André, narrador e personagem, assim como Raduan, escritor e leitor, conhecem os limites da razão e da liberdade, de maneira que à performance gloriosa e visceral do filho pródigo é concedida uma soberania tão absoluta e intensa quanto prisioneira das próprias fronteiras da expressão literária, em que pesem tanto a racionalidade quanto a passionalidade na composição do discurso performático.

Na sequência, lírico e poderoso, o capítulo 20, na hora do crepúsculo, desvela a paixão entre Ana e André, descrevendo as relações sexuais com eufemismos e os projetando no próprio fluxo de consciência do narrador.

com a mão pesada de camponês, assustando dois cordeiros medrosos escondidos nas suas coxas, corri sem pressa seu ventre humoso, tombei a terra, tracei canteiros, sulquei o chão, semeei petúnias no seu umbigo; e pensei também na minha uretra desapertada como um caule de crisântemo, e fiquei pensando que muitas vezes, feito meninos, haveríamos os dois de rir ruidosamente, espargindo a urina de um contra o corpo do outro, e nos molhando como há pouco, e trocando sempre através das nossas línguas laboriosas a saliva de um com a saliva do outro, colando nossos rostos molhados pelos nossos olhos, o rosto de um contra o rosto do outro, e só pensando que nós éramos de terra, e que tudo o que havia em nós só germinaria em um com a água que viesse do outro, o suor de um pelo suor do outro (NASSAR, 2016, p. 117; LA).

Refazendo a lavoura, André converge os lábios vaginais em "cordeiros medrosos", os corpos adolescentes em matéria orgânica, a ejaculação em semeadura vegetal, os líquidos e as 
secreções sexuais em irrigação de uma plantação, o choque mole das línguas em uma androginia submersa em canais subterrâneos para os quais concorrem desde o aroma mais tenro da infância até oralidade profunda das memórias fraternas que se dispersam no éter da casa velha. A semeadura de uma paixão tão ímpia quanto sagrada, favorecendo a promiscuidade da terra que germina em silêncio o trinado de canções dissonantes e poderosas. Novamente com Bataille (2014), a afeição recíproca dos amantes é o apogeu do erotismo dos corações, mais livre e menos funesto que o erotismo dos corpos: "a paixão dos amantes prolonga no campo da simpatia moral a fusão dos corpos entre si. Ela a prolonga ou lhe serve de introdução" (p. 43). Mas a paixão do erotismo dos corações é sentimento ambíguo: mistura do encantamento da fusão dos seres com o sofrimento de perda, que ameaça romper o efeito de continuidade nos seres descontínuos:

\footnotetext{
As chances de sofrer são tanto maiores na medida em que somente o sofrimento revela a inteira significação do ser amado. A posse do ser amado não significa a morte, pelo contrário, mas a morte está envolvida nessa busca. Se o amante não pode possuir o ser amado, pensa às vezes em mata-lo: muitas vezes preferia mata-lo a perde-lo. Deseja em outros casos sua própria morte. O que está em jogo nessa fúria é o sentimento de uma continuidade possível percebida no ser amado. Parece ao amante que só o ser amado [...] pode, neste mundo, realizar o que nossos limites interdizem, a plena confusão de dois seres, a continuidade de dois seres descontínuos. A paixão nos engaja assim no sofrimento, já que ela é, no fundo, a procura de um impossível e, superficialmente, sempre a de um acordo dependente de condições aleatórias. Entretanto, ela promete ao sofrimento fundamental uma saída.

Sofremos de nosso isolamento na individualidade descontínua. A paixão nos repete incessantemente: se possuíres o ser amado, esse coração que a solidão estrangula formaria um só coração com o do ser amado (BATAILLE, 2014, p. 43-44, grifo nosso).
}

O desejo de matar o outro ou de matar-se constitui a violência fundamental que também está no erotismo dos corpos. Trata-se, portanto, de uma violência latente, transitando, também, entre valores e afetos, impregnando objetos com sua ambiguidade e sua força. A aparência de liberdade com o ser amado, na desordem, no absurdo, no sofrimento, dá ao amor o estatuto de milagre. O milagre é a redução da complexidade do mundo na fusão dos seres descontínuos: “o ser amado, para o amante, é a transparência do mundo" (p. 44). Mas o amor requer vigília e rapidamente o tempo leva Ana durante o breve sono de André, que passa a procura-la pela casa velha: "berrei o nome de Ana com todos os meus foles, mas foi inútil, os destroços do jardim em frente não se mexiam no seu sono e os bois naquela hora eram todos de granito, que indiferença, que natureza imunda, nenhum aceno pros meus apelos, que sentimento de impotência!” (NASSAR, 2016, p. 119; LA). Nesse contexto, a natureza tanto é o trágico 
impassível e inerte aos sentimentos humanos (ALMEIDA, 2013), quanto sua face forjada na artificialidade terral dos desejos recíprocos entre Ana e André.

Ana estava na capela rezando pelo pecado cometido. Dali a pouco suas lágrimas vão rolar ao perceber a doença do irmão tresloucado. Ela ficará trancada em seu silêncio, não fará nenhum movimento até partir, com temor, após ouvir as malignas palavras do irmão. André tenta convencê-la calmamente, mas, ao notar a indiferença da irmã, a própria indiferença do tempo e da natureza, sobe no altar da demência e agoniza:

\begin{abstract}
não tenho culpa desta chaga, deste cancro, desta ferida, não tenho culpa deste espinho, não tenho culpa desta intumescência, deste inchaço, desta purulência, não tenho culpa deste osso túrgido, e nem da gosma que vaza pelos meus poros, e nem deste visgo recôndito e maldito, não tenho culpa deste sol florido, desta chama alucinada, não tenho culpa do meu delírio: uma conta do teu rosário para a minha paixão, duas contas para os meus testículos, todas as contas deste cordão para os meus olhos, dez terços bem rezados para o irmão acometido! (NASSAR, 2016, p. 139; LA).
\end{abstract}

André insiste em sua demência, buscando romper o interdito com sua fala transgressiva. Valores em conflito e a agonia de uma família que padece na tenebrosa queda materializada no incesto. André sucumbe e sua impaciência traz a chaga da transgressão primitiva nas entranhas da memória de um sopro oriental. E na falência da missão hermesiana do filho torto, este projeta sua dor mais tangível na imagem do suicídio no vigésimo primeiro capítulo, rechaçando matar a si próprio em prol de um calma impaciência em seu itinerário de exílio, já que “eram também coisas do direito divino, coisas santas, os muros e as portas da cidade" (p. 146). André, ao reavaliar seu percurso enquanto narrador se presta ao serviço do mistério da espera, refazendo seu ímpeto na mobilidade do caminho e dispersando a solidão da imóvel fazenda em um andor terrestre e expansivo até sua reclusão naquela pensão interiorana.

A segunda parte do livro abre com a passagem do Alcorão: "vos são interditas: vossas mães, vossas filhas, vossas irmãs...” (p. 147). A partir deste momento André será tragado pela fúria do tempo, restando à sua volúpia o silêncio do desprendimento. A narrativa, pendendo para o Oriente, desfaz as esperanças ilusórias do irmão desgarrado, que retorna destroçando a paralisia do ar benfazejo naquele ambiente familiar. O gesto austero dos valores da família prevalecendo sobre a prodigalidade do filho errante:

só através da família é que cada um em casa há de aumentar sua existência, é se entregando a ela que cada um em casa há de sossegar os próprios problemas, é preservando sua união que cada um em casa há de fruir as mais sublimes recompensas; nossa lei não é retrair mas ir ao encontro, não é separar mas reunir, onde estiver um há de estar o irmão também (NASSAR, 2016, p. 150; LA). 
Conformado, no capítulo 22, o filho pródigo não só reitera a palavra paterna como confirma a prevalência da família em seu caminho torto, de modo que quanto mais se afasta da casa e da moral familiar, mais estes fantasmas o perseguem, fazendo do retorno um lance inevitável do destino, quer a narrativa possibilite-o, quer a consciência adolescente do protagonista o cobre decisivamente uma resposta a cada instante e a cada passo.

Conforme descreve o vigésimo terceiro capítulo, a volta de André "foi um longo percurso marcado por um duro recolhimento" (p. 151). Naquela casa a expectativa de receber de volta o filho que agora se reconciliaria cinicamente com o pai e com a moral familiar: "aquele que tinha se perdido tornou ao lar, aquele pelo qual chorávamos nos foi devolvido" (p. 152). Ana corre à capela para rezar a volta de André, enquanto Lula o aguarda no quarto para contar que partirá, seguindo os passos do irmão. Um silencioso tumulto corrompe a mesa dos sermões: as quinquilharias da caixa de André, onde guardava objetos devassos, presentes de prostitutas, foi subtraída por Ana, que reaparecerá na festa travestida dos adornos imundos, repulsivos e sensuais. A mãe em seu sofrimento finalmente é percebida por André: "e foi só então que eu pude ver, apesar da luz que brilhava nos seus olhos, quanto estrago eu tinha feito naquele rosto" (p. 157).

O capítulo 24 descreve os lugares à mesa na hora dos sermões: o avô manteria sua cadeira cativa mesmo após a morte. Sabemos que a mesa da família sustenta na madeira cultivada a árvore genealógica da palavra como alimento ancestral, da mesma forma que é o trabalho de autocuidado em conformidade com o trabalho de lavrar a terra e a palavra que fazem da mesa o lugar absoluto das posições dos membros. $\mathrm{O}$ avô em seu silêncio imprevisível se mantém nas raízes, vicejando na continuidade do pai o crescimento de uma árvore marcada pelo trabalho demandando o simbolismo progressista. Esta mesma matéria milenar é o que conforma os valores acabados do pai no derradeiro choque, durante a conversa entre pai e filho, no vigésimo quinto capítulo. André expõe à Iohána seu ponto de vista sobre os conflitos familiares que o levaram a deixar a casa:

\footnotetext{
Imaturo ou não, não reconheço mais os valores que me esmagam [...] nem entendo como se vê nobreza no arremedo dos desprovidos; a vítima ruidosa que aprova seu opressor se faz duas vezes prisioneira, a menos que faça essa pantomima atirada por seu cinismo [...] Estranho é o mundo, pai, que só se une se desunindo; erguida sobre acidentes, não há ordem que se sustente; não há nada mais espúrio do que o mérito, e não fui eu que semeei esta semente (NASSAR, 2016, p. 165; LA).
}

Há, aqui, um paralelo com o Raduan de "A corrente do esforço humano", de modo que aos oprimidos resta não aplaudir seus opressores, mas manter a potência virulenta de sua 
palavra, espaço último e confinado de liberdade possível. Na palavra paterna, o mérito seria o prazer da obediência e do dever. A meritocracia, então, como divisão da zorra mundana, o mérito que subjuga o homem pelo homem, o mérito que põe na geração seguinte o furor incontornável da contingência:

mérito significa merecer-se qualquer coisa; é merecer a recompensa e, reciprocamente, a recompensa é recompensa pelo mérito; numa visão ética do mundo como a dos fariseus, na qual fazer a vontade de Deus é mais importante que todo o resto, é uma bênção ter a Lei e, graças a ela, poder ter ocasiões de lhe obedecer (mitzvoth) e de ter mérito (RICOEUR, 2015, p. 146).

O homem obediente é feliz pois merece fruir a felicidade em razão de seus atos de obediência. Fica patente que Nassar recorre ao termo "fariseu" para que seus personagens refutem a moral fundada na lei, de maneira análoga ao uso que faz Nietzsche. Durante a conversa, o conflito de valores se inflama e o pai se exalta:

Cale-se! Não vem desta fonte a nossa água, não vem destas trevas a nossa luz, não é a tua palavra soberba que vai demolir agora o que levou milênios para se construir; ninguém em nossa casa há de falar com presumida profundidade, mudando o lugar das palavras, embaralhando as ideias, desintegrando as coisas numa poeira [...] ninguém ainda em nossa casa há de dar um curso novo ao que não pode desviar, ninguém há de confundir nunca o que não pode ser confundido [...] Não foi o amor, como eu pensava, mas o orgulho, o desprezo e o egoísmo que te trouxeram de volta à casa! (NASSAR, 2016, p. 171; LA).

A mãe pede que o filho seja poupado e André recua de seu ímpeto desafiador. Ao ceder à moral e ao jugo paterno, André assume ceticamente o fracasso de sua reinvenção moral. Seguem-se palavras da reconciliação: "humilde", "submisso", "disciplina", "tarefas", "lavoura”, "trabalho", "religião”, “cansaço", "união": "quero merecer de coração sincero, pai, todo o teu amor" (p. 172). Seguindo a narrativa, o breve capítulo 26 sinaliza concordância do narrador-personagem com o pai: um homem mesmo quando quebrado não perde sua resistência. Enquanto isso, Lula esperava André no quarto desde sua volta, ao que conta os planos de partida para o irmão:

Não aguento mais esta prisão, não aguento mais os sermões do pai, nem o trabalho que me dão, e nem a vigilância do Pedro em cima do que faço, quero ser dono dos meus próprios passos; não nasci pra viver aqui, sinto nojo dos nossos rebanhos, não gosto de trabalhar na terra, nem nos dias de sol, menos ainda nos dias de chuva, não aguento mais a vida parada desta fazenda imunda (NASSAR, 2016, p. 181; LA).

André está reticente, desiludido, está numa estranha confusão, efeito de sua derrota: Hermes reconhecendo a falha em sua missão conciliatória. Nessa atmosfera um novo incesto 
marca o desfecho do vigésimo sétimo capítulo: "a madrugada haveria também de derramar o orvalho frio sobre os belos cabelos de Lula, quando ele percorresse o caminho que levava da casa para a capela" (p. 184). O caçula é também apanhado pela volúpia incestuosa de André e a culpa presente nas ações de Ana após o incesto é agora reforçada por Lula, transtornado pela virulência do irmão tresloucado.

O capítulo 28 manifesta a reunião desta trama milenar: "a terra, o trigo, o pão, a mesa, a família (a terra); existe neste ciclo, dizia o pai nos seus sermões, amor, trabalho, tempo" (p. 185). A situação estruturante desta oração se configura como alicerce dos sermões paternos, servindo como baldrame para as diversas razões que se insinuam na narrativa. A circularidade evidente no mais breve capítulo do romance manifesta a forma como o pai enxerga o mundo da família. Absorvendo a interpretação de André Luis Rodrigues temos que:

\footnotetext{
A terra, entre parênteses, que fecha o ciclo e que acaba por fechar sintaticamente a palavra família nesse ciclo, entre a terra e (a terra), tanto indica o começo de um novo (mas idêntico) ciclo como sugere que a família é também a terra. A família se fecha dentro dos estreitos limites da propriedade e constitui assim um mundo, o seu mundo, para além do qual [...] tudo é interdito (RODRIGUES, 2006, p. 26).
}

Segundo Rodrigues (2006), a omissão fundamental do discurso paterno ao perfazer esse ciclo seria justamente a razão que o sustenta, partilhada em diferentes frentes por Pedro e pelo avô. É por intermédio da racionalidade que o romance de Nassar convoca as emoções e os sentimentos, já que "a paixão se infiltra nas frestas da razão" (p. 39). O trabalho de André Luis Rodrigues (2006) nos apresenta, portanto, uma coletânea de referências que Raduan utilizou indiretamente na confecção de seu texto, como as configurações totêmicas do incesto e da monogamia, as dimensões antropológicas do trabalho, os aspectos históricos e econômicos do trabalho agrícola, as inspirações da Bíblia e do Alcorão, os jogos discursivos, o apelo às memórias como categorias, as imbricações antropológicas e filosóficas da psicanálise, os enxertos helênicos e mitológicos. Todas estas referências, com a ampla possibilidades de interpretações que a obra de Raduan oferece, justificam a densidade do texto nassariano, que compraz o itinerário de formação do escritor, tanto como leitor, mas também trazendo suas vivências para as páginas dos livros. Tantas são as pistas dos caminhos por onde Nassar passou que fazem da sua interpretação um sempre novo trajeto, reforçando uma circularidade que se expande para fora da literatura, convergindo sua deseducação para o olhar atrevido daqueles que procuram compreendê-lo.

Dando sequência ao desenvolvimento da narrativa, no capítulo 29 repete-se a oriental descrição da festa da primeira parte, agora com desfecho violento, mediante a definitiva 
expressão do tombo na punhalada. Confirmando que a razão não é capaz de se isolar das emoções, o assassínio reintroduz a paixão no estado de coisas criado pela errância humana neste mundo.

\begin{abstract}
era o próprio patriarca, ferido nos seus preceitos, que fora possuído de cólera divina (pobre pai!), era o guia, era a tábua solene, era a lei que se incendiava - essa matéria fibrosa, palpável, tão concreta, não era descarnada como eu pensava, tinha substância, corria nela um vinho tinto, era sanguínea, resinosa, reinava drasticamente as nossas dores (pobre família nossa, prisioneira de fantasmas tão consistentes!), e do silêncio fúnebre que desabara atrás daquele gesto, surgiu primeiro, como de um parto, um vagido primitivo (NASSAR, 2016, p. 195; LA, grifo nosso).
\end{abstract}

O transtorno e o desterro do assassinato tumultuam e viram a mesa dos sermões, à revelia da austeridade e do comedimento pregados, confirmando o destino como algoz e recuperando à fórceps o lado obscuro da fé e dos valores familiares. A “cólera divina" confirma a amálgama entre o sacro e o profano, vivificando a religião como metáfora e como sustentáculo da moral familiar. Deus é senão a lavoura paterna incorporada, com todas as suas ambiguidades obtusas, no éter que ressoa cotidianamente daquela família. Diante do insólito desenredo anunciado a contragosto, a linguagem se põe ao avesso, reinstalando o trinado de instrumentos insuspeitados nas vastas geografias que se dispersam às custas de memórias-correntes, fazendo não só das ideias, mas dos sentimentos, das emoções e das sensações um caldo espesso de onde não se pode jamais inferir água cristalina.

Iohána! Iohána! Iohána! e foram inúteis todos os socorros, e recusando qualquer consolo, andando entre aqueles grupos comprimidos em murmúrio como se vagasse entre escombros, a mãe passou a carpir em sua própria língua, puxando um lamento milenar que corre ainda hoje a costa pobre do Mediterrâneo: tinha cal, tinha sal, tinha naquele verbo áspero a dor arenosa do deserto (NASSAR, 2016, p. 196; LA, grifo nosso).

O estertor alegre da festa, enfim, se reveste em uma "missa negra", tumultuando o ventre de uma mulher sem nome, cuja tessitura impõe ao imaginário da queda uma oração igualmente inominável, da qual o timbre cinde de uma vez por todas em estilhaços vivos e carnais as águas dos territórios da memória. O milagre reverso esvazia em um só gesto o mar Mediterrâneo, desviando e decompondo em frangalhos e flagelos a história subsequente que advém aos nossos dias, entornando uma quantidade assombrosa de cal e sal em nossos mares, sem com isso curar a ferida aberta que a queda expõe a um só tempo em cada palavra proferida pelos homens. A geografia e a arquitetura que se desfazem nos gestos terríveis e complementares da mãe e do pai são as estruturas de uma ciência de menino, que André recompõe em sua narrativa passional, 
radicando na palavra a imensidão ausente de muitas lavouras arcaicas fabricadas com cuidado na morada de cada família. Este premente desterro possibilita ao romance nassariano uma tradução herege dos vernáculos que compõem nossa cultura, deseducando com erudição a partir da própria banalidade imperiosa do cotidiano.

Finalmente, o deserto, o vazio, a distância, a ausência e a falência de valores se inflamam em uma impossível dor, destronando em definitivo o amparo racional no trato civilizatório. Com Ricoeur (2015), a imagem do deserto recupera, afinal, o abandono da divindade, o homem largado à sua própria sorte. Este espaço vazio é preenchido pela efervescência de sentimentos intempestivos, transtornando no corpo e no espírito dos parentes a efetividade das lacunas do discurso paterno. Às frestas da palavra ancestral se impõe a imagem terrificante do destino, como descrito no capítulo-epílogo 30: “o gado vai sempre ao poço” (NASSAR, 2016, p. 198; LA).

\subsection{O QUE NÃO TEM GOVERNO, NEM NUNCA TERÁ}

A deseducação nassariana não só dispersa e põe em cheque ideais de sociedade, comunidade e grupo social, como descaracteriza a própria noção de homo sapiens, ao que fica patente seu empenho em tornar evidente o caráter demens da espécie. A projeção do demens nos escritos de Nassar se dá rompendo paradigmas das idades da vida, desfazendo o idílico da infância, a potência do adulto e a sabedoria da velhice. Ao desinvestir a razão e o progresso moral em seu processo de deseducação, Raduan reenvia a vida à sua dimensão sensível e (est)ética. Em $L A$, para recuperar a razão sensível, o escritor põe em cena a (con)fusão entre metafísica e natureza, fertilizando o vocabulário asséptico da razão através da expressão corporal e profanando as referências religiosas em ritos pagãos. Assim sendo, o delírio, o transe, a demência e o desvario insurgem como componentes difusas nos sentidos corporais, amplificados pelo poder dos elementos da natureza. Por isso, a dimensão sensível e estética da vida não é passível de controle, justamente porque é a vida ela mesma impossível de se governar, sob os contornos do trágico que nos (des)ampara.

\subsubsection{Raízes}

Lavoura arcaica narra a solidão, a angústia e a agonia, de modo que os sentimentos, as sensações e a corporeidade das paixões se interpõem nas fissuras da razão e da ordem. O personagem André simboliza a condição humana diante dos conflitos morais, oriundos de regras e tabus estabelecidos no espaço longínquo das memórias ancestrais. A ruptura da 
condição idílica da infância expressa a cisão radical no âmbito do erotismo sagrado, de modo que a linguagem interpõe na criança o crivo da moral, retirando a livre violência do ímpeto animal e estabelecendo os códigos de conduta e os valores desejados pelo grupo social. Esse hibridismo entre a vontade e a ordem estabelecida é instado por uma panaceia cultural entre Ocidente e Oriente, recuperando o berço mediterrânico para a deseducação nassariana:

mitos, costumes e símbolos no mundo mediterrânico se encaixam em duas rubricas sociológicas: enquanto certas populações pastoris ou certas camadas étnicas levantam altares, prestam culto ao fogo masculino, ao Sol, aos pássaros ou ao céu, outros, pelo contrário, levam uma vida sedentária de agricultores, contentam-se com pedras esfregadas com sangue à guisa de altar, invocam divindades femininas e telúricas (DURAND, 2016, p. 36-37).

Um dos traços pagãos importantes em $L A$ é a veneração da terra, em que pese os odores que ela dispõe. A invocação da terra alcança, todavia, a própria animalidade terrestre, constelando terra e animais e o que deles provêm em uma rede simbólica captada na memória de perfumes antigos. André, imerso em sua liturgia telúrica, se autoproclama "pastor lírico", evocando a memória do tio flautista, que fora pastor na infância:

\begin{abstract}
amo nossas cabras e nossas ovelhas, sei aconchegar nos braços o cordeiro tímido dum mês, tenho um carinho especial para a rês assustada, vou misturar no meu pastoreio a flauta rústica, a floração do capim e a brisa que corre o pasto; tenho alma de pastor, querida irmã, sei fazer que cada espécie se conheça, sendo mestre até das cruzas mais suspeitas, sei como multiplicar as cabeças do rebanho do pai; e ajuntarei a essa riqueza o cuidado com todas as aves, nossas galinhas tão gregárias, os gaios exuberantes, o contorno gracioso dos marrecos de andar trôpego, os patos achatados do bico aos pés, os perus estufados, assim como as angolas ariscas e de voos tão aventureiros que trazem na cabeça um caroço mórbido à guisa de crista; sei colher ovos nos ninhos, fazer que uma choca bem quente se deite eternamente sobre ovos alheios, e, no paiol, não causo alvoroço às botadeiras assustadiças que põem seus ovos pudicos no fundo dos balaios ou em ninhos suspensos perigosamente do travejamento das vigas (NASSAR, 2016, p. 124-125; LA, grifo nosso).
\end{abstract}

A correção e o zelo com que o filho arredio descreve o cuidado com os animais confere a ele um talento alquímico de manipulação das espécies, como quem detém artimanhas divinas da terra. À irmã-amante, Ana, aparentemente converge a simbologia, já que durante o ato sexual, o irmão adverte que "éramos de terra" (p. 117). Neste ritual telúrico também é recuperado o ato do sacrifício e a potência da morte: “com os pés brancos e limpos fui afastando as folhas secas e alcançando abaixo delas a camada de espesso húmus, e a minha vontade incontida era de cavar o chão com as próprias unhas e nessa cova me deitar à superfície e me cobrir inteiro de terra úmida" (p. 193). De dentro das raízes telúricas se insinuam árvores que 
vicejam, crescendo naturalmente, como crescem as paredes das edificações da fazenda, dispersando no ar os odores secretos das origens familiares:

\begin{abstract}
povoaram a atmosfera de resinas e de unguentos, carregando nossos cheiros primitivos, esfregando nossos narizes obscenos com o pó dos nossos pólens e o odor dos nossos sebos clandestinos, cavando nossos corpos de um apetite mórbido e funesto; sentindo duas mãos enormes debaixo dos meus passos, me recolhi na casa velha da fazenda, fiz dela o meu refúgio, o esconderijo lúdico da minha insônia e suas dores, tranquei ali, entre as páginas de um missal, minha libido mais escura; devolvendo às origens as raízes dos meus pés, me desloquei entre ratos cinzentos, explorei o silêncio dos corredores, percorri a madeira que gemia, as rachas nas paredes, janelas arriadas, o negrume da cozinha, e, inflando minhas narinas para absorver a atmosfera mais remota da família, ia revivendo os suspiros esquálidos pendendo dos caibros com as teias de aranha, a história tranquila debruçada nos parapeitos, uma história mais forte nas suas vigas (NASSAR, 2016, p. 94-95; LA, grifo nosso).
\end{abstract}

A sinestesia das memórias amplia o olfato para além da terra, materializando a geografia daqueles confins nas casas da fazenda, erguidas com caibros provenientes daquele próprio ecossistema: "existiu primeiro uma terra propícia, existiu depois uma árvore secular feita de anos sossegados, e existiu finalmente uma prancha nodosa e dura trabalhada pelas mãos de um artesão dia após dia" (p. 56). Os cheiros impregnam os espaços, dissolvidos no ar, consagrando o turvo retrato das memórias em uma emoção prosaica que intumesce a consciência quando desperta do sono cotidiano. Assim, a terra se amplia na humidade das refeições, em panelas, tachos e utensílios de toda ordem que convocam também uma luminosidade peculiar. A luz, neste foco, com essas cores, somente o odor da infância pode prover: “era boa a luz doméstica da nossa infância, o pão caseiro sobre a mesa, o café com leite e a manteigueira, essa claridade luminosa da nossa casa e que parecia sempre mais clara quando a gente vinha de volta lá da vila" (p. 29-30). Entretanto, a amálgama das raízes históricas da família preenche o espaço com um excesso de ausência, inquietando e refinando o olfato de André, que em vão tenta interpretar a torrente daqueles aromas: "que resinas se dissolviam na danação do espaço, me fustigando sorrateiras a relva delicada das narinas? que sopro súbito e quente me ergueu os cílios de repente?" (p. 53).

Mediante a aglutinação sinestésica do protagonista com os animais, se confunde a raiz ancestral que diferencia o homem das "bestas". Nessa direção, segundo Bataille (2014), um aspecto decisivo na diferenciação entre homens e animais é o trabalho. Outro aspecto são os interditos, elementos arcaicos da cultura, como também observa Edgar Morin (1973). A genealogia dos interditos é solidária da ritualização da morte, que seria um dos principais fatores da hominização. $\mathrm{O}$ trabalho como atividade propriamente humana e sua síncope de 
grupo em determinado momento encontrou a consciência da morte e a percepção da sexualidade envergonhada, conferindo referências ancestrais ao imaginário da queda.

\begin{abstract}
Já que o trabalho, ao que parece, engendrou logicamente a reação que determina a atitude diante da morte, é legítimo pensar que o interdito que regula e limita a sexualidade também foi um contragolpe ao trabalho, e que o conjunto das condutas humanas fundamentais - trabalho, consciência de morte, sexualidade contida remontam ao mesmo período recuado (BATAILLE, 2014, p. 54, grifo nosso).
\end{abstract}

Nesse caso, o que os sentidos de André capturam nos territórios da fazenda, sobretudo na casa velha, são profusões de um indiscernível bálsamo arcaico, tão afastado na história quanto presente nos desígnios daquele contexto familiar, exilando o discernimento que vê no controle dos instrumentos e das ferramentas o domínio da natureza pelo trabalho. O que o filho arredio sugere é o contrário: a natureza irrompe com sua fúria e sua força desfazendo sem critério e ao acaso o trabalho humano, incluindo na dimensão laboral as edificações morais. A proliferação de sentidos é intensa a partir das investidas da natureza, manifesta no tempo, de modo que a moral paterna, parafraseando a sabedoria oriental, sugere a paciência como possibilidade de conviver com o tempo:

\begin{abstract}
rico só é o homem que aprendeu, piedoso e humilde, a conviver com o tempo [...] ninguém em nossa casa há de dar nunca o passo mais largo que a perna [...] ninguém em nossa casa há de colocar nunca o carro à frente dos bois [...] ninguém ainda em nossa casa há de começar nunca as coisas pelo teto [...] o mundo das paixões é o mundo do desequilíbrio, é contra ele que devemos esticar o arame das nossas cercas [...] nenhum entre nós há de transgredir esta divisa (da casa), nenhum entre nós há de estender sobre ela (cerca) sequer a vista [...] ninguém em nossa casa há de cruzar os braços quando existe a terra para lavrar, ninguém em nossa casa há de cruzar os braços quando existe a parede para erguer, ninguém ainda em nossa casa há de cruzar os braços quando existe o irmão para socorrer [...] cultivada com zelo pelos nossos ancestrais, a paciência há de ser a primeira lei desta casa [...] o amor na família é a suprema forma de paciência; o pai e a mãe, os pais e os filhos, o irmão e a irmã: na união da família está o acabamento dos nossos princípios (NASSAR, 2016, p. 56-64; LA, grifo nosso).
\end{abstract}

Os valores do pai começam na paciência e terminam no amor, situando o trabalho como anteparo para quaisquer outros valores. Iohána, sob a simbólica diurna do trabalho, relacionase com o tempo tentando vencê-lo produtivamente, pacientemente, lançando mão do amor em cumprir a lei e semear. O trabalho é considerado na narrativa como sinônimo de cura, sanidade, saúde, equilíbrio: "uns poucos dias de trabalho ao lado de teus irmãos hão de quebrar o orgulho da tua palavra, te devolvendo depressa a saúde de que você precisa" (p. 163). Além disso, o trabalho selaria o contrato social, dando liga às funções de cada membro no grupo. 
Os sentidos que captam os odores da terra alcançam o caldo inóspito das raízes familiares nos agrupamentos humanos, que em seu arremedo remoto traduzem a animalidade dos homens. Nessas raízes tão longínquas quanto turvas residem as difusas instituições morais que em corpo e em cultura, via linguagem, resplandecem o trabalho (a razão), o amor (o erotismo) e o tempo (a morte) como atributos de uma genealogia comum entre povos de muitas geografias, banhadas por mares insuspeitados, perdidos nos oceanos da geração da vida.

\subsubsection{Fluídos}

O romance dinamiza fluxos de concentração e dispersão, recuo e salto. O tempo consagra a angústia fundamental consoante a qual a obra responde através de diferentes valores que buscam superá-la simbolicamente. $\mathrm{O}$ homem responde à sua face terrífica eufemizando a angústia na materialidade da imaginação simbólica. De um lado, a primazia do cristianismo e sua lei, de outro, ressonâncias orientais da violência transgressora e sagrada do mundo primitivo. Em uma ponta as demandas do trabalho, na outra, as súplicas do corpo erótico. No intercurso agônico destas forças, o amor ambíguo, hesitante, derrubando dicotomias, fundando conflitos, ruindo edifícios, perturbando a paz, planificando a guerra.

Aquém da miséria dos homens, o tempo e sua austeridade; suas diabruras compondo serenidades secretas e conduzindo dilemas milenares. Na casa, num quarto escuso. Em algum tempo de infância, em algum tempo da história humana, a vida em seu ímpeto. A casa, como observado, é homóloga aos objetos, as roupas e ao corpo da família. A casa manifesta a agonística diante do interdito ao erotismo corporal à medida que é o receptáculo das memórias e dos afetos repercutindo a face ferina da lei em cada roupa e cada objeto:

\footnotetext{
A casa constitui [...] entre o microcosmo do corpo humano e o cosmo, um microcosmo secundário, um meio-termo cuja configuração iconográfica é, por isso mesmo, muito importante no diagnóstico psicológico e psicossocial [...] Os poetas, os psicanalistas, a tradição católica ou a sabedoria dos dogon fazem coro para reconhecer no simbolismo da casa um duplicado microcósmico do corpo material e do corpo mental [...] a casa é labirinto tranquilizador, amado apesar do que pode no seu mistério subsistir de ligeiro temor (DURAND, 2002, p. 243).
}

A casa é a morada, o berço e, sobretudo, o ventre que se reitera como símbolo nos textos nassarianos. O ventre materno em comunhão com a casa e o bosque constituem o desejo de regressão à mãe, ao instante idílico de continuidade, intimidade, anterior à queda, anterior à moral. Mas na tentativa desta regressão impossível, o que as águas revelam ao filho torto é um caldo fumegante de onde brotam gotas ardentes: 
enxergando os utensílios, e mais o vestuário da família, que escuto vozes difusas perdidas naquele fosso, sem me surpreender contudo com a água transparente que ainda brota lá do fundo; e recuo em nossas fadigas, e recuo em tanta luta exausta, e vou puxando desse feixe de rotinas, um a um, os ossos sublimes do nosso código de conduta (NASSAR, 2016, p. 79; LA).

Este "fosso" é recorrentemente citado por André, de onde ressoa as raízes mais fundas dos preceitos morais, entranhadas nos próprios corpos daqueles meninos e meninas. Em outro momento, o narrador conforma as origens na imagem do poço, demandando que as palavras austeras e ancestrais proveem de uma genealogia insuspeitada, para a qual concorre tanto o ventre materno quanto as lacunas da turva corrente que liga o passado ao presente:

marcando o silêncio úmido daquele poço, só existia um braço de sol passando sorrateiro por uma fresta do telhado, acendendo um pequeno lume, poroso e frio, no chão do assoalho; incidindo em cada canto meu tormento sacro e profano, ia enchendo os cômodos em abandono com minhas preces, iluminando com meu fogo e minha fé as sombras esotéricas que fizeram a fama assustada da casa velha (NASSAR, 2016, p. 95 ; LA).

O mistério dessas águas que fluem o curso da vida preserva no repouso a virulência dos estigmas submersos. A tranquilidade e a calma constelam com a feminilidade, de onde os fluídos circulam à guisa de repouso e recuo. Tal rede simbólica favorece a interpretação de Ana como face oculta do próprio André, já que o filho tresmalhado apenas encontra alento na paixão pela irmã: "é que o andrógino, microcosmo de um ciclo em que as fases se equilibram sem que nenhuma seja desvalorizada em relação à outra, é, no fundo, justamente um 'símbolo de união'. Ele é a díade por excelência, que põe uma tônica igual nas duas fases, nos dois tempos do ciclo" (DURAND, 2012, p. 292). A reconciliação do andrógino é a possibilidade de continuidade/intimidade, como se pode ver nestes dois trechos:

foi um milagre o que aconteceu entre nós, querida irmã, o mesmo tronco, o mesmo teto, nenhuma traição, nenhuma deslealdade, e a certeza supérflua e tão fundamental de um contar sempre com o outro no instante de alegria e nas horas de adversidade; foi um milagre, querida irmã, descobrimos que somos tão conformes em nossos corpos, e que vamos com nossa união continuar a infância comum, sem mágoa para os nossos brinquedos, sem corte em nossas memórias, sem trauma para a nossa história; foi um milagre descobrirmos acima de tudo que nos bastamos dentro dos limites da nossa própria casa, confirmando a palavra do pai de que a felicidade só pode ser encontrada no seio da família (NASSAR, 2016, p. 122; LA, grifo nosso).

entenda que quando falo de mim é o mesmo que estar falando de você, entenda ainda que nossos dois corpos são habitados desde sempre por uma mesma alma (NASSAR, 2016, p. 133; LA, grifo nosso). 
A angústia existencial de André difere da moral paterna. Se o trabalho tenta resolver a angústia existencial no galho da direita, no galho da esquerda é o afeto que buscará transpô-la. Por acaso, o amor fraterno também é um valor no discurso do pai e é a ambivalência do amor no próprio patriarca a brecha do delírio de André, que busca a conciliação do afeto materno com a austeridade materna. Ana, por sua vez, seria a outra face do filho pródigo: o mistério, o segredo, as contradições do amor familiar. Lembremos que o feminino é propositalmente abafado nos textos de Raduan. E é no contexto desta repressão, que a mãe, André, Ana e Lula transformam o lar em uma "casa de perdição", de modo que é a própria indeterminação da vontade, enquanto força irracional, o que instala a prisão nos corpos, transpondo a culpa em angústia e tensão:

\footnotetext{
o cativeiro do corpo, e até o cativeiro da alma no corpo, constituem um símbolo do mal que a alma inflige a si mesma, o símbolo da afecção da liberdade por si mesma; o fato de a alma se vir a encontrar "solta" [déliement] assegura retrospectivamente que suas "amarras" eram impostas pelo desejo, por um fascínio simultaneamente passivo e ativo, por um cativeiro autoimposto: "perder-se" significa precisamente isso (RICOEUR, 2016, p. 173).
}

Com a lei paterna a família supera o tempo cíclico do avô e entra em uma estrutura de sensibilidade heroica, marcada pelo progresso e pelo trabalho. As forças noturnas são o contraponto dessa austeridade, tendo a mãe como orientadora afetiva e Ana como objeto de transgressão. André sucumbe à transgressão incestuosa com Ana e, daí em diante, tentará reconciliar as forças contrárias recuperando nas memórias do avô um tempo no qual a transgressão e o sagrado se envolviam em um só laço de intimidade. No entanto, o incesto é o “interdito universal”, o que torna vã a missão de André. A angústia decorrente dessa condição é fruto de um choque de maneiras de lidar com o tempo e a danação marca o isolamento em uma cadeia de conflitos internos. Mais do que isso, com Ricoeur (2015), pensamos na solidão total, a materialização da culpa:

que o "eu" seja mais enfatizado que o "perante ti”, que o "perante ti”" seja mesmo
esquecido, então a consciência da falta torna-se culpabilidade e já não pecado; agora
é a consciência que se torna "medida" do mal numa experiência de solidão total; não
é por acaso que em diversas línguas uma só palavra designa a consciência moral e o
despertar da consciência psicológica e reflexiva; a culpabilidade é a expressão, por
excelência, da promoção da consciência ao estatuto de instância suprema (RICOEUR,
2015, p. 121).

O feminino admite, no intercurso da culpa, a personificação da angústia radicada na espera. Porém, se a angústia é a projeção imaterial do tempo, os fluídos são a materialização 
dos corpos reprimidos pela ordem masculina, o que congrega na mesma constelação a menstruação de Lucila em "Monsenhores", o vômito da "Menina a caminho", as águas que precipitam o mergulho do narrador de "Aí pelas três da tarde", a urina de André e Ana no incesto de Lavoura arcaica, jorrando uma calda espessa na secura dos ambientes nassarianos. É, portanto, a fluidez dos líquidos corporais o que assinala a permanência dos corpos no universo patriarcal que drena as emoções em prol de uma suposta razão asséptica. Nesse caso, a presença dos fluídos atravessa as narrativas nassarianas partilhando do mesmo espaço que os alimentos, confluindo excreção e digestão como conflui olfato e paladar para agregar memórias e construir cenários sufocantes.

Os alimentos se fazem presentes em "A corrente do esforço humano", "O velho", "Menina a caminho", "Monsenhores", Um copo de cólera e Lavoura arcaica, convocando o paladar como coadjuvante da caldeira, flamejando as raízes movediças dos conflitos morais. Os valores humanos em contraste são, por conseguinte, uma tônica na obra de Raduan, caracterizada pela contradição circular dos opostos, que fluem a ponto de se confundirem entre si, nesta amálgama para a qual convergem olfato, paladar, terra e água. Os símbolos de poder e sexualidade nos textos nassarianos constelam no imaginário da queda, advento da moral no homem, de modo que a matéria-prima da caldeira será senão os valores humanos:

\begin{abstract}
deve-se, sem dúvida, compreender que ao criar o homem livre, Deus deu-lhe uma liberdade finita. A finitude dessa liberdade consiste nisto: que ela é desde a origem orientada, não, sem dúvida, por aquilo a que chamamos "valores", que são produtos culturais já muito elaborados, mas por um princípio de hierarquização e de preferência entre os valores. Esta estrutura ética da liberdade constitui a própria autoridade dos valores em geral (RICOEUR, 2015, p. 267).
\end{abstract}

É, afinal, o aspecto feminino da razão que convoca a fluidez dos corpos, engrossando o caldo dos cenários nassarianos, atribuindo sem demora o epíteto demens à corrente do esforço humano. O homem nassariano é, portanto, remoto, solitário, cativo, agônico, tomado por conflitos de valores e crises morais, agraciado pela recusa, pela revolta e pela indignação. Excluído, apartado, incomunicável, impermeável, insaciável, egoísta, amargo, delirante, indiferente, falível; artífice de seus próprios fantasmas, de suas próprias correntes.

\title{
5.2.3 O edifício e a caldeira
}

Se da terra provém o alimento, da água provém o paladar que, por sua vez, fermenta a saliva conferindo gostos e valores para as palavras experimentadas. Neste terreno de rituais, crendices, sacrifícios, neste tempo ímpio, profano e herege é que são moldadas as paredes das 
hierarquias humanas, escondendo nas fissuras dos caibros e das colunas uma lava densa e movediça. O poder é assim formulado, na alquimia requintada da purulência dos corpos. Em Nassar, a caldeira é senão o símbolo da fabricação de valores, situando o baldrame das relações humanas na faísca de uma chama adormecida após ser concretada. Não obstante, basta reacender o fogo que o fervilhar de insetos, larvas e úlceras sem demora se insinue nas frestas da aparente inércia. Desse modo, é a própria concepção de valores, sustentados em critérios omissos, o que faz da razão que os fundamenta uma categoria manchada.

Em Lavoura arcaica, o símbolo da contaminação, do pecado e da volúpia, é o galho da esquerda (a mãe, André, Ana e Lula): “como se a mãe, que era por onde começava o segundo galho, fosse uma anomalia, uma protuberância mórbida, um enxerto junto ao tronco talvez funesto, pela carga de afeto" (NASSAR, 2016, p. 158-159; LA). Não é demais reiterar que a árvore em $L A$ converge para a imagem do edifício, perfazendo uma construção como qualquer outra na corrente humana, concretada a partir daquela caldeira inflamada. A menção direta à caldeira ocorre em dois momentos em $L A$. No primeiro aparece junto aos preceitos do pai:

nenhum entre nós há de cair jamais na fervura desta caldeira insana, onde uma
química frívola tenta dissolver e recriar o tempo; não se profana impunemente ao
tempo a substância que só ele pode empregar nas transformações, não lança contra ele
o desafio quem não receba de volta o golpe implacável do seu castigo; ai daquele que
brinca com fogo: terá as mãos cheias de cinza; ai daquele que se deixa arrastar pelo
calor de tanta chama: terá a insônia como estigma; ai daquele que deita as costas nas
achas desta lenha escusa: há de purgar todos os dias; ai daquele que cair e nessa
queda se largar: há de arder em carne viva; ai daquele que queima a garganta com
tanto grito: será escutado por seus gemidos (NASSAR, 2016, p. 59; LA, grifo nosso).

Note-se a riqueza de sentidos que o trecho nos oferece, confirmando a caldeira como espaço de (re)criação do tempo e, consequentemente, de valores, à medida que a imaginação simbólica existe enquanto convenção imaginária em resposta à ameaça de morte. Além disso, o imaginário da queda se insinua para aqueles que se prestam a antecipar as mudanças, confirmando a centralidade do Anjo Mal nos textos nassarianos. A adequação de André a esta ousadia prevenida pelo pai fica patente em outra passagem do romance, quando o irmão torno, desprovido do amor de Ana, insinua trabalhar com a caldeira, entrevendo nesta alquimia o fervilhar explosivo:

estou banhado em fel, Ana, mas sei como enfrentar tua rejeição, já carrego no vento do temporal uma raiva perpétua, tenho o fôlego obstinado, tenho requintes de alquimista, sei como alterar o enxofre com a virtude das serpentes, e, na caldeira, sei como dar à fumaça que sobe da borbulha a frieza da cerração nas madrugadas; vou cultivar o meu olhar, plantar nele uma semente que não germina, será uma terra que não fecunda, um chão capaz de necrosar como as geadas as folhas das árvores, as 
pétalas das flores e a polpa dos nossos frutos; não reprimirei os cantos dos lábios se a peste dizimar nossos rebanhos, e nem se as pragas devorarem as plantações [...] já faço parte da escória, vou me entregar de corpo e alma à doce vertigem de quem se considera, na primeira força da idade, um homem simplesmente acabado, bastante ativo contudo para furar fundo com o indicador a carne podre da carcaça, e, entre o polegar e o anular, com elegância, fechar trópicos e outras linhas, atirando num ossário o esqueleto deste mundo (NASSAR, 2016, p. 140-141; LA, grifo nosso).

A partir do discurso flamejante de André a visão vem constelar com o fogo através do olho que gora, apimentando o fervilhar daqueles que comentam e apontam outrem, julgando e condenando em sua performance alcoviteira, adicionando ainda os dedos que junto aos olhos apontam e predizem o mal em suas caldeiras, o que nos sugere, dentre outras referências, a atmosfera de "Menina a caminho". Assim sendo, como se pode notar em vários textos de Raduan, as hierarquias se formulam a partir do "pecado original", as relações de poder, como sugerido em "A corrente do esforço humano". Contudo, conforme o ensaio nos adverte é lícito questionar quais dores e sofrimentos concorreram para edificar as belas casas dos valores dominantes. Nesse caso, a potência explosiva da caldeira verte a argamassa nas colunas dos edifícios, fazendo de qualquer tábua de valores o resultado de conflitos sangrentos, dominação, violação, ruptura, na alquimia sórdida de obscuras passagens do itinerário humano.

\subsubsection{Ritmos}

$\mathrm{O}$ ar nos textos de Nassar é parado e sufocante. Porém, é o vento quem cuida de dispersar mensagens por diferentes geografias, levando a fumaça da caldeira para os rincões onde pensam se isolar os indiferentes. A sensibilidade de André captava os "mensageiros mais velozes, mais ativos, [que] montavam melhor o vento, corrompendo os fios da atmosfera" (NASSAR, 2016, p. 16; LA, grifo nosso). É no vento que surgem as boas novas, o trinado implacável das mudanças, oriundo da fumaceira de chamas longínquas, tateando com desenvoltura o sopro e incorporando o desajuste nas relações presentes. É através do ar que a volúpia das novidades se mostra como uma performance ligeira, conferindo um ritmo cadenciado e imprevisível ao acaso cotidiano:

Pondo folhas vermelhas em desassossego, centenas de feiticeiros desceram em caravana do alto dos galhos, viajando com o vento, chocalhando amuletos nas suas crinas, urdindo planos escusos com urtigas auditivas, ostentando um arsenal de espinhos venenosos em conluio aberto com a natureza tida por maligna (NASSAR, 2016, p. 94; LA).

Outrossim, são os ritmos o que possibilitam as mudanças no universo nassariano, de modo que os caminhos são percorridos enquanto os personagens vão tateando como cegos em 
suas missões imprecisas, demandando a dimensão dinâmica do movimento hermesiano de conciliação. Lavoura arcaica circula, sobretudo, no regime noturno do imaginário durandiano, embora a hierarquia familiar, a palavra e o trabalho do pai constelem no regime diurno. Símbolos ascensionais, diairéticos e de iluminação são evocados para proteger e resgatar os desviados. André, ligado ao galho da esquerda, quer retomar o tempo cíclico manifesto pelo avô, evocando o erotismo sagrado. Investe-se em uma missão hermesiana de conciliação dos contrários: lei paterna versus transgressão incestuosa. André rompe, isto posto, como mediador entre estas forças em combate:

\begin{abstract}
O símbolo do Filho seria uma tradução tardia do androginato primitivo das divindades lunares. O Filho conserva a valência masculina ao lado da feminilidade da mãe celeste. [...] o Filho manifesta assim um caráter ambíguo, participa na bissexualidade e desempenhará sempre o papel de mediador. Que desça do céu à terra ou da terra aos infernos para mostrar o caminho da salvação, participa de duas naturezas: masculina e feminina, divina e humana (DURAND, 2002, p. 300).
\end{abstract}

Os dois regimes em conflito tenderiam para uma neutralização, mas André falha em sua missão. A força solar, cujo símbolo mais notável é o pai, anula a força mística manifesta em Ana. O desfecho reitera a danação agonística de valores conflitantes como constituição das relações humanas (familiares e sociais). Entretanto, a inviabilidade de conciliação é um fator comum nos textos nassarianos, o que torna os desfechos das narrativas o prenúncio de novas tensões, reforçando a impossibilidade de paz nas relações humanas, uma vez que a resolução dos conflitos tende ao fracasso.

A garota em "Menina a caminho", André e Pedro em LA, as formigas em Um copo de cólera (CC), as andorinhas ou aves de rapina em "A corrente do esforço humano", estas imagens constelando em favor das mudanças, repercutindo nos espaços ocos e fechados dos territórios nassarianos a primazia de uma dança, capaz de evocar na ancestralidade da flauta, os ecos da poderosa influência das memórias no tempo presente. Diante dos estertores da explosão, finda a volúpia flamejante do discurso impiedoso de André na capela, tal como o chacareiro em $C C$, o irmão acometido desaba sob o manto de um silêncio ensurdecedor:

\footnotetext{
“estou morrendo, Ana", eu disse largado numa letargia rouca, encoberto pela névoa fria que caía do teto, ouvindo a elegia das casuarinas que gemiam com o vento, e ouvindo ao mesmo tempo um coro de vozes esquisito, e um gemido puxado de uma trompa, e um martelar ritmado de bigorna, e um arrastar de ferros, e surdas gargalhadas (NASSAR, 2016, p. 144; LA).
}

Nestes termos, os ventos trazem também o prenúncio das palavras ocas e austeras dos valores milenares, confundindo-se em caminhos traiçoeiros, ao que se repetem à escuta e aos 
olhos de regentes alheios, conduzindo ritmos e sons da tradição às investidas descarnadas e virulentas. Os passeios de uma menina, os movimentos calculados em uma pensão interiorana, a "geometria passional" da dança familiar, a convulsão performática dos atores no palco, o transe da busca por afeto, ritmos deslocando o ar e tateando o caminho entre luzes e sombras, possibilitando ao vento a dispersão de estórias aos corpos que as recebem.

\subsubsection{Memórias}

O alicerce soberano das edificações nassarianas é, afinal, a memória, para a qual concorrem todos os sentidos em profusão. E a plenitude da memória se realiza na palavra, gesto soberano do escritor. A musicalidade da linguagem se multiplica no éter como finca estacas em cada um dos sentidos, recuperando na audição o resultado de um conjunto de sentimentos e sensações amalgamados em odores, gostos, cores, formas e sons. Lavoura arcaica atende aos desígnios da memórias refluindo os sons de lembranças tão intempestivas quanto ancestrais, refazendo no avô uma caixa de ressonância dos ocos acordes de cítaras extintas:

\footnotetext{
Em memória do avô faço esse registro: ao sol e às chuvas e aos ventos, assim como a outras manifestações da natureza que faziam vingar ou destruir nossa lavoura, o avô, ao contrário dos discernimentos promíscuos do pai - em que apareciam enxertos de várias geografias, respondia sempre com um arroto tosco que valia por todas as ciências, por todas as igrejas e por todos os sermões do pai: “Maktub” (NASSAR, 2016, p. 91; LA, grifo nosso).
}

Nada pode contra o divino, trágico e tirano algoz, o tempo (Cronos), personificado na figura do avô. O silêncio implacável e tirano do avô convoca o inominável, que se dispersa no ambiente como um elemento integrador de todas as substância, entoando um cântico inaudível em cada canto da casa, convocando um terrível domínio sobre o destino daquelas meninas e meninos:

era ele, Pedro, era ele na verdade nosso veio ancestral [...] era ele na verdade que nos conduzia [...] era esse velho asceta, esse lavrador fenado de longa estirpe que na modorra das tardes antigas guardava seu sono desidratado nas canastras e nas gavetas tão bem forradas das nossas cômodas, ele que não se permitia mais que o mistério suave e lírico, nas noites mais quentes, mais úmidas, de trazer, preso à lapela, um jasmim rememorado e onírico, era ele a direção dos nossos passos em conjunto, sempre ele, Pedro, sempre ele naquele silêncio de cristaleiras, naquela perdição dos corredores, nos fazendo esconder os medos de meninos detrás das portas, ele não nos permitindo, senão haustros contidos, sorver o perfume mortuário das nossas dores que exalava das suas solenes andanças pela casa velha; era ele o guia moldado em gesso, não tinha olhos esse nosso avô, Pedro, nada existia nas duas cavidades fundas, ocas e sombrias do seu rosto, nada, Pedro, nada naquele talo de osso brilhava além da corrente do seu terrível e oriental anzol de ouro (NASSAR, 2016, p. 48-49; LA, grifo nosso). 
O tempo, afinal, como o avô em $L A$, se instala em cada objeto, cada roupa, nos alimentos, na repetição e nas mudanças, "o tempo, esse algoz às vezes suave, às vezes mais terrível, demônio absoluto conferindo qualidade a todas as coisas, é ele ainda hoje e sempre quem decide e por isso a quem me curvo cheio de medo e erguido em suspense me perguntando qual o momento, o momento preciso da transposição?” (p. 101). André, preenchendo o percurso do imaginário, quer vencer Cronos, domesticando-o em sua "ciência de menino" capaz de capturar a pomba no momento certo, admitindo Kairós como amuleto.

\begin{abstract}
ambição fundamental de dominar o devir pela repetição dos instantes temporais, vencer diretamente Cronos já não com figuras e num simbolismo estático, mas operando sobre a própria substância do tempo, domesticando o devir. Os arquétipos e esquemas que se polarizam em torno dessa ambição fundamental são tão poderosos que chegam, nas mitologias do progresso, nos messianismos e nas filosofias da história, a ser tomados como realidade objetiva, como moeda válida do absoluto e já não como resíduo concretizado de simples estruturas singulares, de simples trajetos da imaginação (DURAND, 2012, p. 282).
\end{abstract}

Manifestam-se, em $L A$, símbolos de uma estrutura de sensibilidade rítmica. Essas imagens aparecem, sobretudo, ligadas à memória do avô. A mesa da família manifesta a cisão ancestral reportada no mito adâmico, entre o tempo cíclico e o tempo progressivo, e a partir de então o desenvolvimento dos seus dois galhos que coincidem com os regimes diurno e noturno do imaginário, o esquema disseminatório equilibrará as estruturas solares e místicas: "porque a verticalização da árvore orienta, de uma maneira irreversível, o devir e humaniza-o de algum modo ao aproximá-lo da estação vertical significativa da espécie humana. Insensivelmente, a imagem da árvore faz-nos passar da fantasia cíclica à fantasia progressista” (DURAND, 2012, p. 338).

Nessa direção, sob a queda, no mito adâmico, o homem moraliza-se. Quando se instala o tempo progressivo - o pai como profeta - quebra-se o equilíbrio inicial manifesto pelo avô. Os sermões do pai não sustentam a coesão do grupo familiar pois sua relação com o sagrado estará contaminada por seu próprio ímpeto violento, que consagra o dramático final do romance. Assim sendo, a promiscuidade das memórias investe a busca de André por uma solução alquímica capaz de dominar o tempo. Com isso, o irmão virulento empenha todos os sentidos para captar os caminhos percorridos pelas palavras ancestrais, impregnadas em cada corpo desta estória familiar. No entanto, a falência de André como missionário tresloucado assinala e reitera a primazia do tempo e da natureza como imperiosos motivadores da imaginação simbólica, conquanto seu combate se preste a produção de obras que nos possam fazer esquecer deste inevitável destino, a morte. 
Neste capítulo abordamos a obra Lavoura arcaica como elogio da dimensão sensível e estética da vida, completando o ciclo de análises da obra completa de Raduan Nassar. Ao fim e ao cabo, em torno do imaginário da queda, arranjo escolhido para guiar nossas análises, estão situadas inumeráveis outras configurações simbólicas que poderiam igualmente traduzir a relevância da literatura de Raduan Nassar para constituir um processo de deseducação. Nesse caso, pensamos que as tessituras da queda, ao colocarem em cena os deslindes da construção de valores, podem tornar evidente a radicalidade desta deseducação nassariana, destituindo a razão asséptica e o progresso moral em favor de uma (est)ética formativa firmada na visceralidade performática da linguagem, senão imposta como silêncio do homem comum. 


\section{CONSIDERAÇÕES FINAIS}

Esta pesquisa foi ancorada no contexto de uma mudança paradigmática, sob o corte de um "novo espírito científico", como propôs Gaston Bachelard ao reinvestir os símbolos e as imagens como formas legítimas de conhecimento. Neste registro, seu discípulo Gilbert Durand consolidou uma antropologia do imaginário, de onde provém um conjunto de hermenêuticas instauradoras do caráter epifânico da imaginação simbólica, com as quais dialoga o pensamento de Paul Ricoeur.

No primeiro capítulo desenvolvemos esta abordagem incluindo a discussão dos itinerários de (auto) formação como possibilidades de enxergar o fenômeno educacional de maneira ampla, dando vazão aos aspectos formativos da leitura e da literatura. Os outros quatro capítulos que o sucedem contemplam os resultados desta pesquisa, cujo objetivo foi apresentar simbolicamente a obra completa de Raduan Nassar em torno de um imaginário da queda.

Percorremos o universo nassariano descrevendo uma dinâmica simbólica que coloca em evidência os conflitos de valores, as crises morais e a emergência da sexualidade e do corpo na construção das relações humanas. Sendo assim, acreditamos que os textos de Nassar trazem à tona o caráter movediço da razão que fundamenta os códigos morais, os tabus, as relações de poder e as possibilidades de uma ética emancipatória. Este movimento favorece a compreensão do caráter demens do ser humano, restando à linguagem uma dimensão material e corporal, o que confirma e complementa a interpretação de Estevão Azevedo (2015). Não obstante, como apontou André Luis Rodrigues (2006), as narrativas nassarianas se interpõem nas frestas da razão, o que em nosso trabalho multiplicamos nas tessituras simbólicas da linguagem, em que pese a primazia do arquétipo da queda velando sobre o universo de Raduan.

Principalmente em Um copo de cólera e "O ventre seco" o modus operandi da racionalidade fica patente, mediante as caricaturas e os enxertos empregados. Outrossim, o pensamento uno, as dicotomias, e o ascetismo da razão vão sendo destituídos a partir das ambiguidades e contradições que emergem, de modo que a inversão dos argumentos é um recurso oportunamente aplicado pelos personagens, o que reforça o arbítrio da linguagem. Ao apontar os limites da razão e se lançar contra o pensamento dogmático, Raduan questiona, por exemplo, o jornalismo como depositário da verdade: "que compromisso existe? Você pode falar alguma coisa e falar o seu contrário. E daí?” (NASSAR, 1995, p. 9).

O caráter arbitrário da linguagem se limita quando vai ao encontro da materialidade corporal daquele que expressa, fazendo dos olhos e da observação formas assumidas pela 
verdade em cada sujeito e em cada contexto, desconformando qualquer universalidade. Além disso, a convivência entre narrativas e verdades opostas coloca em cena um terceiro incluído como mediador gerando potência para a miríade de possibilidades de uma razão sensível. A arbitragem deste "anjo do mal" ancora a paixão na economia da linguagem confundindo critérios ora assumidos como certezas e abrindo um halo de indeterminação na observação dos fenômenos cotidianos.

Desfeita a hegemonia da razão ascética, Nassar desmonta o progresso moral quando declara ser o homem uma obra acabada, o que se complementa na circularidade sufocante de seus cenários, nos limites que ora transpostos se reafirmam, nas (as)simetrias que conectam imagens e textos, perfazendo paradoxos que dificultam ao leitor precisar quem ou o que está incluído ou excluído dos contextos sociais, familiares e conjugais. A frustração de uma eventual evolução do ser humano qualifica a história como um processo contínuo de mudanças cuja inteligibilidade e coerência escapam, atirando a temporalidade para o mesmo fosso indiscernível habitado pela razão.

Uma vez destituídos o progresso moral e a razão que o sustenta, a ética emancipatória se torna turva e movediça, corrompendo violentamente os fundamentos da educação moderna e habilitando uma deseducação, uma (de)formação que o universo do autor precipita no leitor. Este processo, observado por um olhar transdisciplinar ou mesmo indisciplinar, reitera os itinerários de (auto) formação, já que o atravessamento existencial que a literatura oferece consagra a constituição dos sujeitos.

No expediente desta deseducação são vivificados o caráter performático da linguagem e do texto e a fruição cotidiana do homem comum, elementos que caracterizam uma (est)ética formativa. Os jogos crepusculares que Nassar põe em cena confundem o discernimento entre o grotesco e o sublime, fazendo da dinâmica entre sombra e luz um caminhar infindável, o que assinala a potência estética da vida na performance textual e no vigor do silêncio. Tais operações de estilo interpõem ao fenômeno ético a convivência da expressão com a autoridade dos sentidos, emoções e sentimentos daquele que fala, confundindo a caldeira dos valores e o sinuoso receptáculo da estética.

Contudo, se a visceralidade e a verborragia da fala não satisfazem, a quietude e o cotidiano se impõem, de onde entrevemos uma legião de anônimos fazendo literatura nas insuspeitadas cozinhas do mundo, cheirando a alho e cebola. Tão legítimos em sua fruição da vida que correm o risco de fazer da literatura apenas uma coisinha na (des)ordem geral do mundo: o "bom mesmo é dormir" (NASSAR, 1997b, p. 10). O delírio se impõe como opção de liberdade nos pequenos lances do dia a dia, anunciando sem demora que é uma razão menor o 
que governa o homem comum. Se a vida antecede a literatura, o mundo-do-texto será, afinal, a continuidade deste incontornável jogo de linguagem que perfaz as relações humanas, lançando em narrativas as múltiplas possibilidades de existir.

Com este trabalho almejamos contribuir com a produção acadêmica das áreas de cultura e filosofia da educação na expectativa de continuidade e multiplicação de pesquisas educacionais sob vieses amplos. Além disso, deixamos uma singela contribuição para a fortuna crítica de Nassar, sugerindo abordagens plurais do fenômeno literário. Afinal, desejamos que este trabalho incorpore valor às ricas abordagens transdisciplinares nos horizontes da antropologia do imaginário e da hermenêutica simbólica. 



\section{REFERÊNCIAS}

ABATI, H. M. F. Da Lavoura Arcaica: fortuna crítica, análise e interpretação da obra de Raduan Nassar. Dissertação (Mestrado). Curitiba: UFPR, 1999.

ABBOUD, M. Lavoura arcaica e os símbolos do mal: uma leitura crítica da violência contra a mulher. Tese (Doutorado em Teoria e História Literária). Instituto de Estudos da Linguagem. Universidade Estadual de Campinas. Campinas, SP: [s.n.], 2017.

ABRAMOVICH, F (org.). Ritos de passagem de nossa infância e adolescência: antologia. São Paulo: Summus, 1985.

ALMEIDA, M. C. Um itinerário do pensamento de Edgar Morin. ano 2, n. 18. São Leopoldo, RS: Unisinos, 2004.

ALMEIDA, R. Machado de Assis: imaginário trágico e ética da ocasião. In: MONTEIRO, S. A. I. (org.). Culturas contemporâneas, imaginário e educação: reflexões e relatos de pesquisas. 1 ed. São Carlos, SP: RiMa Editora, p. 227-238, 2010.

R. Aprendizagem de desaprender: Machado de Assis e a pedagogia da escolha. Educação e Pesquisa (USP. Impresso), v. 39, p. 1001-1016, 2013.

, R. O mundo, os homens e suas obras: filosofia trágica e pedagogia da escolha. 2015. $204 \mathrm{f}$. Tese (Livre-Docência). Universidade de São Paulo, São Paulo, 2015.

, R. Antiniilismo: ou a superação do niilismo pela filosofia trágica. Revista de Estudos de Cultura, v. 3, p. 75-83, 2015 b.

ARAÚJO, A. F.; BERGMEIER, H. Jung e o tempo de Eranos: do sentido espiritual e pedagógico do Círculo de Eranos. Revista @ mbienteeducação, 6(1), 94-112, jan-jun, 2013.

ARISTÓTELES. Metafísica. $2^{a}$ ed. Série Clássicos Edipro. Tradução de: Edson Bini. São Paulo: Edipro, 2012.

ARQUIVO FAMILIAR. Perdidas entre os afazeres na cozinha. 1920's. 1 fotografia, p/b, digital.

A depositária espiritual de um patrimônio escasso. 1969. 1 fotografia, p/b, digital.

A gravidade negra e erecta dos ciprestes. 1969.1 fotografia, $\mathrm{p} / \mathrm{b}$, digital.

Era uma ciência de menino. 1969. 1 fotografia, p/b, digital.

Nada de porraloquice. 1969. 1 fotografia, p/b., digital.

Não tinha olhos esse nosso avô. 1969. 1 fotografia, p/b, digital.

O cirquinho é hoje! 1969. 1 fotografia, p/b, digital.

O galho da esquerda. 1969. 1 fotografia, p/b, digital.

Um ginasiano pedalando tranquilamente. 1969.1 fotografia, p/b, digital.

. Aquele bando de moços e moças. 1981. 1 fotografia, color., digital.

Da outra vez teve aquilo. 1981. 1 fotografia, color., digital. 
O café da manhã. 1981. 1 fotografia, color., digital.

Uma fotografia castanha. 1981. 1 fotografia, color., digital.

ATHAYDE, T. Romances. Jornal do Brasil. Rio de Janeiro, p. 11. 05 ago. 1976.

AZANHA, J. M. P. Uma reflexão sobre a didática. In: , J. M. P. Educação: alguns escritos.

São Paulo: Ed. Nacional, p. 70-77, 1987.

AZEVEDO, E. A. O corpo erótico das palavras: um estudo da obra de Raduan Nassar. 209 f. Dissertação (Mestrado em Literatura Brasileira). Faculdade de Filosofia, Letras e Ciências Humanas. Universidade de São Paulo, 2015.

E. Oportuna, compilação da obra de Raduan Nassar ganha densidade. Folha de São Paulo. Ilustrada, p. 3. São Paulo, 22 out. 2016.

E. A. Pelas palavras e pelo silêncio, Raduan é um gigante. Folha de São Paulo. Ilustrada, p. 1. São Paulo, 31 mai. 2016b.

BACHElARD, G. A filosofia do não; O novo espírito científico; A poética do espaço. $2^{\mathrm{a}}$ ed. Traduções de: Joaquim José Moura Ramos et al. Coleção Os Pensadores. São Paulo: Abril Cultural, 1984.

$\overline{1989 .}$

G. A água e os sonhos: ensaio sobre a imaginação da matéria. São Paulo: Martins Fontes,

, G. A poética do devaneio. 3. ed. Tradução de: Antônio de Pádua Danesi. São Paulo: Editora Wmf Martins Fontes, 2009.

BAPTISTA, F. P. "Nota introdutória: da imaginação criadora ao imaginário". In: WUNENBURGER, J. J.; ARAÚJO, A. F.; ALMEIDA, R. (coord.). Os trabalhos da imaginação: abordagens teóricas e modelizações. João Pessoa: Editora da UFPB, 2017.

BATAILLE, G. A literatura e o mal. Tradução de: Suely Bastos. Porto Alegre: L\&PM, 1989.

G. O erotismo. Tradução de: Fernando Scheibe. Belo Horizonte: Autêntica Editora, 2014.

G. Teoria da religião: seguida de Esquema de uma história das religiões. Tradução de:

Fernando Scheibe. Belo Horizonte: Autêntica Editora, 2015.

BAUDRILLARD, J. A transparência do mal: ensaio sobre os fenômenos extremos. Tradução de: Estela dos Santos Abreu. Campinas, SP: Papirus, 1990.

BAYARD, P. Como falar dos livros que não lemos? Tradução de: Rejane Janowitzer. Rio de Janeiro: Objetiva, 2007.

BERTÉ, M. M. O taciturno e o epistolar: estudo do silêncio no conto de Raduan Nassar. Mafuá. Revista de Literatura em Meio Digital, ano 5, n. 7, 2007.

BETCHEREV, W. La psycbologie objective. Paris, FR: Alcan, 1913.

W. General principies of human reflexology. Londres, 1933.

BETCHEREV, W.; BERITOFF, I. S.; OUFLAND, J. M.; OUKHTOMSKY, A.; VINOGRADOV, M. Novoï é Reflexologuii i Fisiologuii Nervnoï Systemi (2 vol.). Léningrad - Moscou, 1926. 
BOHM, E. Traité psychodiagnostic de Rorschach. 2 vol. Paris, FR: P. U. F., 1955.

CANDIDO, A. O direito à literatura. In: A. Vários Escritos. São Paulo: Duas cidades, 1995. A. A literatura e a formação do homem. In: , A Textos de Intervenção. São Paulo: Duas Cidades/Editora 34, 2002.

CARMONA, G. F. A literatura narrasiana e a filosofia das vontades. Diálogo e Interação. ISSN 2175-3687. v. 5, 2011.

CHAUVIN, J. P. Raduan Nassar, para além da estante. 2017. Disponível em: <http://jornal.usp.br/artigos/raduan-nassar-para-alem-da-estante/>. Acesso em: 27 nov. 2018.

CIORAN, E. M. La chute dans le temps. Paris, FR: Gallimard, 1990.

, E. M. Del inconveniente de haber nacido. $2^{\mathrm{a}}$ ed. Tradução de: Esther Seligson. Madri, ES: Taurus, 1998.

CARVALHO, J. C. P. Antropologia das organizações e educação: um ensaio holonômico. Rio de Janeiro: Imago Ed, 1990.

CASSIRER, E. Ensaio sobre o homem: uma introdução a uma filosofia da cultura humana. Ed: Martins Fontes, São Paulo. 1994.

COIMBRA, R. A. Do arcaico ao moderno: tradição e (des)continuidade em Lavoura arcaica, de Raduan Nassar. Tese (Mestrado em Letras). Dourados, UFGD, 2011.

DIAS, R. M. Arte e vida no pensamento de Nietzsche. Cad. Nietzsche [online]. 2015, vol. 36, n. 1, p. 227-244. ISSN 2316-8242. Disponível em: <http://www.scielo.br/pdf/cniet/v36n1/2316-8242-cniet36-01-00227.pdf>. Acesso em: 27 nov. 2018.

DELEUZE, G. Diferença e repetição. Tradução de: Luiz Orlandi e Roberto Machado. Rio de Janeiro, Graal: 1988.

G. A literatura e a vida. In: G. Crítica e Clínica. São Paulo: Editora 34, 2006.

DESCARTES, R. Descartes: obras escolhidas. Tradução de: J. Guinsburg, Bento Prado Jr., Newton Cunha e Gita K. Guinsburg. GUINSBURG, J.; ROMANO, R.; CUNHA, N. (org.). São Paulo: Perspectiva, 2010.

DEUSSEN, P. Schopenhauer e a religião. Revista Voluntas: Estudos sobre Schopenhauer - v. 4, n. 1 - jan.-jun., 2013, p. 131-138.

DURAND, G. A imaginação simbólica. Tradução de: Eliane Fittipaldi Pereira. São Paulo: Cultrix/Editora da Universidade de São Paulo, 1988.

, G. Campos do imaginário. Lisboa, PT: Instituto Piaget, 1996.

G. As estruturas antropológicas do imaginário. 4. ed. Tradução de: Hélder Godinho. São Paulo: Editora WMF Martins Fontes, 2012.

DURHAM, E. R. A dinâmica da cultura: ensaio de antropologia. São Paulo: Cosac Naify, 2004.

ELIADE, M. Mito e realidade. São Paulo: Editora Perspectiva, 1989. 
EVANGELHO SEGUNDO SÃO LUCAS. In: BÍBLIA DE JERUSALÉM. Tradução de: Paulus Editora. São Paulo: Paulus, 2002.

FERREIRA, M. P. À flor da pele: escrileitura do sensual. 127 f. Dissertação (Mestrado), Universidade Federal do Rio Grande do Sul, Porto Alegre, 2008.

FERREIRA-SANTOS, M. Práticas crepusculares: mytho, ciência e educação no Instituto Butantan: um estudo de caso em antropologia filosófica. Tese (Doutorado em Educação). Faculdade de Educação. Universidade de São Paulo, 1998.

Zouk, 2004.

M. Crepusculário: conferências sobre mitohermenêutica e educação em Euskadi. São Paulo:

M. Fundamentos antropológicos da arte-educação: por um pharmakon na didaskalia artesã.

Revista @mbienteeducação, v. 3, n. 2, p. 59-97, jul-dez, 2010.

FERREIRA-SANTOS, M.; ALMEIDA, R. Antropolíticas da educação. São Paulo: Képos, 2011. , M.; Képos, 2012. , R. Aproximações ao imaginário: bússola de investigação poética. São Paulo,

FREIRE, Paulo. A importância do ato de ler: em três artigos que se completam. São Paulo, Cortez, 2003.

FREUD, S. O mal-estar na civilização. Tradução de: José Octávio de Aguiar Abreu. Rio de Janeiro: Imago Ed., 1997.

GADAMER, H. G. Verdade e Método. 4. ed. Tradução de: Flávio Paulo Meurer. Petrópolis: Vozes, 1997.

GARCIA, A.; HEREDIA, B. Trabalho familiar e campesinato. América Latina, ano 14, n. 1-2, jan./jun., 1971.

HENRIQUE, G.; NAVARRO, C. As três batalhas de Raduan Nassar. Le Monde Diplomatique. v. 121. Brasil, 18 set. 2017. Disponível em: <https://diplomatique.org.br/as-tres-batalhas-de-raduannassar/>. Acesso em: 27 nov. 2018.

HEREDIA, B. A Morada da Vida. Trabalho familiar de pequenos produtores do Nordeste do Brasil. Rio de Janeiro: Paz e Terra, 1978.

ISER, W. O ato de leitura: uma teoria do efeito estético. v. 2. Tradução de: Johannes Kretschmer. São Paulo: Ed. 34, 1999.

JUNG, C. G. (Org.) O homem e seus símbolos. Tradução de: Maria Lúcia Pinho. Rio de Janeiro: Nova Fronteira, 2008.

KUHN, T. A estrutura das revoluções científicas. São Paulo: Perspectiva, 2007.

LAVOURA ARCAICA. Direção de Luiz Fernando Carvalho. Brasil, 2001.

LAVOURA ARCAICA - Edição Especial. Direção de Luiz Fernando Carvalho. Brasil, 2007.

LEMOS, M. J. C. Raduan Nassar: apresentação de um escritor entre tradição e (pós) modernidade.

Estudos Sociedade e Agricultura, Rio de Janeiro, UFRJ, v. 1, n. 20, p. 81-112, 2003. 
, M. J. C. Desdobras deleuzianas: o ventre seco de Raduan Nassar. Synergies Brésil, n. spécial 2, p. 93-99, 2010. Disponível em: <https://gerflint.fr/Base/Bresil_special2/lemos.pdf〉. Acesso em: 14 mai. 2019.

M. J. C. Estamos indo sempre para casa: Raduan Nassar, Novalis e o devir no Bildungsroman. Revista Ecos, Cáceres, v. 9, p. 91-105, 2010 b.

LESOURD, S. A construção adolescente no laço social. Petrópolis, RJ: Vozes, 2004.

LESTRINGANT, F. O Brasil de Montaigne. Rev. Antropol. v.49, n. 2. São Paulo, jul./dez. 2006.

LIMA, J. Invenção de Orfeu. Rio de Janeiro: Alfaguara, 2017.

LYOTARD, J. F. A condição pós-moderna. Tradução de: Ricardo Corrêa Barbosa. Rio de Janeiro: José Olimpo, 2009.

MAFFESOLI, M. Elogio da razão sensível. Tradução de: Albert Christophe Migueis Stuckenbruck. Petrópolis, RJ: Vozes, 1998.

MASOTTA, O. O comprovante da falta. Campinas: Papirus, 1989.

MASSI, A. "Menina a caminho". In: FFLCH (São Paulo). Revisitando Raduan - Colóquio em homenagem aos 80 anos do escritor. 2015. Disponível em:

<https://www.youtube.com/watch?v=Ff2KsZ2sakg>. Acesso em: 27 nov. 2018.

MONBEIG, P. Pionniers et planteurs de São Paulo. Paris, FR: Armand Colin, 1952.

MORIN, E. O paradigma perdido: a natureza humana. Lisboa: Europa-América, 1973.

E. Ciência com consciência. $6^{a}$ ed. Tradução de: Maria D. Alexandre e Maria Alice Sampaio Dória. Rio de Janeiro: Bertrand Brasil, 2002.

, E. A cabeça bem-feita: repensar a reforma, reformar o pensamento. $8^{\text {a }}$. ed. Tradução de: Eloá Jacobina. Rio de Janeiro: Bertrand Brasil, 2010.

NASSAR, R. "Raduan Nassar". In: STEEN, E. V. Viver \& escrever. Porto Alegre, v. 2, L\&PM: 1983. Entrevista concedida a Edla Van Steen.

, R. “A paixão pela literatura”. In: Folha de São Paulo. São Paulo, 16 dez., 1984. Entrevista concedida a Augusto Massi e Mario Sabino Filho.

R. Nachahmung und Eigenwert. Tradução de: Ray-Güde Mertin. In: MEYER-CLASON, C. (org.). Lateinamerikaner über Europa. Frankfurt: Suhrkamp, 1987.

R. "Silêncio ruidoso”. In: Revista Veja. São Paulo, 29 mar., 1989.

, R. "Do culto das letras ao cultivo da lavoura". In: Jornal do Brasil, Rio de Janeiro, 29 ago. 1992. Entrevista concedida a Liliane Heynemann.

, R. "Nassar relança Um copo de cólera". In: Folha de São Paulo. Ilustrada, p. 9. São Paulo, 19 abr. 1992b. Entrevista concedida a Marilene Felinto.

, R. Raduan vive a literatura como questão pessoal. In: Folha de São Paulo. São Paulo, p. 5-6.

30 mai. 1995. Entrevista concedida a Elvis Cesar Bonassa. 
R. Cadernos de Literatura Brasileira, v. 2, São Paulo: Instituto Moreira Salles, 1996.

, R. Menina a caminho e outros textos. São Paulo: Companhia das Letras, 1997.

, R. “Sou o jararaca”. In: Revista Veja, São Paulo, p. 9; 12-13, 30 jul. 1997b. Entrevista concedida a Mario Sabino.

, R. "Europa descobre palavra fértil de Raduan Nassar; Nassar prefere falar de sua terra a escrever”. In: O Estado de São Paulo, 14 mar. 1998. Entrevista concedida a Norma Couri.

1999.

, R. “Rural x urbano”. In: Folha de São Paulo. Brasil, Caderno 1, p. 12. São Paulo, 22 ago.

, R. Obra completa. São Paulo: Companhia das Letras, 2016.

, R. "Estamos bem arrumados!” In: O Globo. 2016b. Disponível em:

<https://oglobo.globo.com/opiniao/estamos-bem-arrumados-19135938>. Acesso em: 27 nov. 2018.

, R. "Cegueira e linchamento". In: Folha de São Paulo. 2016c. Disponível em:

<http://www1.folha.uol.com.br/opiniao/2016/08/1805156-cegueira-e-linchamento.shtml>. Acesso em: 27 nov. 2018.

NEUMANN, G. R. Brasileiros sobre a Europa - Brasil: além do centro e da periferia? Porto Alegre, Revista Contingentia, Vol. 2, novembro, p. 29-35, 2007.

NIETZSCHE, F. W. Ecce homo. Tradução de: Paulo César Lima de Souza. São Paulo: Companhia das Letras, 1995.

, F. W. Humano, demasiado humano. Tradução de: Paulo César Lima de Souza. São Paulo: Cia das Letras, 2000.

, F. W. Crepúsculo dos ídolos: ou como se filosofa com o martelo. Tradução de: Paulo César de Souza. São Paulo: Companhia das Letras, 2001.

, F. W. Para além do bem e do mal: prelúdio a uma filosofia do futuro. São Paulo: Editora Martin Claret, 2005.

, F. W. A genealogia da moral. São Paulo: Companhia das Letras, 2005b.

, F. W. Assim falou Zaratustra: um livro para todos e para ninguém. Tradução de: Paulo César de Souza. São Paulo: Companhia das Letras, 2011.

NOVALIS. Henri d'Ofterdingen. Edição bilíngue. Tradução de: Marcel Camus. Alençon: Aubier, 1942.

PAGOTTO-EUZEBIO, M. S.; ALMEIDA, R. (org.) Sobre a ideia do Humano. São Paulo: Képos, 2012.

PERRONE-MOISÉS, L. "Da cólera ao silêncio". In: NASSAR, R. Cadernos de Literatura Brasileira, v. 2, São Paulo: Instituto Moreira Salles, 1996.

PITTA, D. P. R. Iniciação à teoria do imaginário de Gilbert Durand. Rio de Janeiro: Atlântica Editora, 2005. (Coleção Filosofia). 
POSTAY, L. A história nos nomes: patriarcalismo em lavoura arcaica, de Raduan Nassar. In: ALMEIDA, J.; SIEGA, P. (orgs.). Literatura e voz subalterna: anais. Vitória: GM, 2013.

QUEIROGA, M. F. C. Raduan Nassar: uma poética da leitura a partir de sua escritur-ação e de seus personagens. 137 f. Dissertação (Mestrado em Literatura e Interculturalidade). Centro de Educação Departamento de Letras e Artes. Universidade Estadual da Paraíba.

REBOUL, O. Filosofia da Educação. SP: Editora Nacional, 1988.

RICOEUR, P. A função hermenêutica do distanciamento. In: , P. Interpretação e ideologias. São Paulo, Francisco Alves, 1988.

, P. Hermenêutica e ideologias. Rio de Janeiro: Vozes, 2008.

P. Escritos e conferências 2: hermenêutica. São Paulo: Edições Loyola, 2011. $70,2015$.

P. A Simbólica do Mal. Tradução de: Hugo Barros e Gonçalo Marcelo. Lisboa, PT: Edições

RODRIGUES, A. L. Ritos da paixão em Lavoura arcaica. São Paulo, EDUSP, 2006.

, A. L. Do Paribar, em São Paulo, ao Porto de Santos: algumas reflexões em esboço sobre a "obra pronta" de Raduan Nassar e Modesto Carone. Teresa Revista de Literatura Brasileira [10|11]. São Paulo, p. 282-297, 2010.

ROSSET, C. Lógica do pior. Rio de Janeiro: Espaço e Tempo, 1989. 2008.

C. A ilusão e seu duplo. In: , C. O real e seu duplo. Rio de Janeiro: José Olympio,

, C. La filosofia trágica. Buenos Aires, AR: El cuenco de plata, 2010.

SALVIANO, J. O. S. O fundamento epistemológico da metafísica da vontade de Arthur Schopenhauer. Trans/Form/Ação, São Paulo, 32(2): 101-118, 2009.

SCHUTZ, A. Fenomenología del mundo social: introdução a la sociologia compreensiva. Buenos Aires: Paidos, 1972.

SILVA, R. C. A. A tra(d)ição dos nomes na Lavoura arcaica, de Raduan Nassar. Revista Philologus. Rio de Janeiro: UERJ, ano 11, p. 19-26, 2003.

TARDIVO, R. C. Literatura e psicanálise: a poética de Raduan Nassar. Percurso, São Paulo, v. 47, p. 85-100, 2011.

UM COPO DE CÓLERA. Direção de Aluizio Abranches. Brasil, 1999.

VANEAU, C. R. G. Memória e ancestralidade: lastros que ecoam e escoam na contemporaneidade. Revista Sala Preta, v. 16, n. 1, 2016.

WILSON, E. O. Sociobiology. The abridged edition. Cambridge, EUA: Harvard University, 1998.

WUNENBURGER, J. J.; ARAÚJO, A. F. Educação e imaginário: introdução a uma filosofia do imaginário educacional. São Paulo: Cortez, 2006.

WUNENBURGER, J. J. O imaginário. São Paulo, Edições Loyola, 2007. 